Portland State University

PDXScholar

$7-28-2000$

\title{
The Dynamics of the Planktonic Communities of Two Oregon Reservoirs
}

Miguel Angel Estrada

Portland State University

Follow this and additional works at: https://pdxscholar.library.pdx.edu/open_access_etds

Part of the Ecology and Evolutionary Biology Commons Let us know how access to this document benefits you.

\section{Recommended Citation}

Estrada, Miguel Angel, "The Dynamics of the Planktonic Communities of Two Oregon Reservoirs" (2000). Dissertations and Theses. Paper 4307.

https://doi.org/10.15760/etd.6191

This Thesis is brought to you for free and open access. It has been accepted for inclusion in Dissertations and Theses by an authorized administrator of PDXScholar. Please contact us if we can make this document more accessible: pdxscholar@pdx.edu. 


\section{THESIS APPROVAL}

The abstract and thesis of Miguel Angel Estrada for the Master of Science in Biology were presented July 28, 2000, and accepted by the thesis committee and the department.

COMMITTEE APPROVALS:

\section{Richard R. Petersen, Chair}

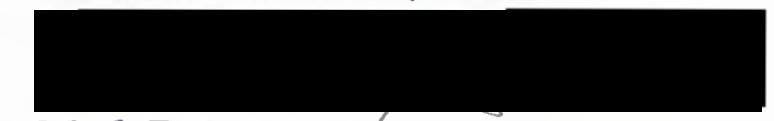

Mark D. Sytsma

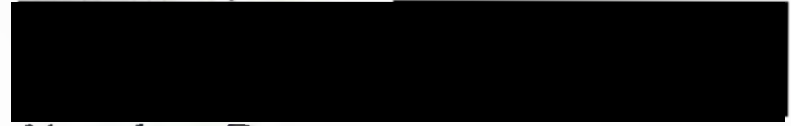

Yangdong Pan

Representative of the Office of Graduate Studies.

DEPARTMENT APPROVAL:

Stanley S. Hillman, Chair

Department of Biology 


\section{ABSTRACT}

An abstract of the thesis of Miguel Angel Estrada for the Master of Science in Biology presented July 28, 2000.

Title: The Dynamics of the Planktonic Communities of Two Oregon Reservoirs.

From June 1998 to July 1999, the dynamics of the plankton in Hagg Lake and Barney Reservoir were studied with the purpose to identify the succession dynamics of the planktonic species, to test the Plankton Ecology Group (PEG) model, and to explore the relationships between these successions and the physical and chemical variables.

Using data from the variables measured together with a reservoir conceptual model, inferences were made about the interactions of the physical and chemical components and their effects on the plankton. Based on the observed interactions, three statements are made:

1. Hagg Lake and Barney Reservoir have a mesotrophic lacustrine zone.

2. For Hagg Lake:

a) Changes in water levels appear to regulate dissolved oxygen concentrations. 
b) Summer disturbances in the watershed of Hagg Lake appeared to increase sediment loadings.

3. For Barney Reservoir:

a) Extreme variations in water levels influenced the temperature regime of the water column and the nutrient dynamics.

Based on the discrepancies between the PEG model predictions and the observed succession, two statements are made:

A. In Hagg Lake, high winter 1998 and early spring 1999 water inflows and mixing did not allow a stable winter - spring succession. Species adapted to low light and low temperatures were common.

B. The early start of mixing in Barney Reservoir interrupted the fall succession, and a continuous 'resetting' of the succession favored populations of cryptomonads and small zooplankters.

Conclusions:

1. A model to identify the dimensions and factors that define a reservoir under study should be developed if a model of reservoir planktonic dynamics is to emerge. 
2. The PEG model needs to be modified to include longitudinal variations in the concentrations of nutrients and the effects of convective and dispersive forces.

3. A hypothesis is put forth regarding the plankton dynamics should fish stocking be initiated in Barney Reservoir: With fish exerting more pressure on cyclopoids, calanoids will be able to colonize the reservoir; in turn grazing-resistant algae, adapted to low nutrients, will become more abundant. 
THE DYNAMICS OF THE PLANKTONIC COMMUNITIES

OF TWO OREGON RESERVOIRS

by

MIGUEL ANGEL ESTRADA

A thesis submitted in partial fulfillment of the requirements for the degree of

MASTER OF SCIENCE

in BIOLOGY

Portland State University

2000 
Dedication:

To my mother Concepcion, and my grandmother Josefa. 
Acknowledgments:

I want to thank Dr. Richard R. Petersen, my advisor, for all his help. I also want to acknowledge the help and advice of Dr. Yangdong Pan. Thanks to Dr. Mark Sytsma for the corrections and ideas.

Advice on the methods for nutrient analysis and laboratory how-to came generously from Kris Hueftle. The design of the field sampling also took shape thanks to his advice, Thanks Kris.

Thanks to the personnel of the ESR office for their efforts to facilitate the transportation to the reservoirs. Thanks to Karl Borg and the Forest Grove Water Treatment Plan for the partial support to conduct this study.

Thanks to Kazuiro Sonoda for all his aid in the laboratory and in the preparation of the defense of this thesis. Thanks to Paul Gill and Robert Perkins, and to many other PSU students for their help. Thanks to Allen Hamel, DEQ Oregon, for his help in creating the thermistor array.

Thanks to my wife Lydia for her support. 


\section{TABLE OF CONTENTS}

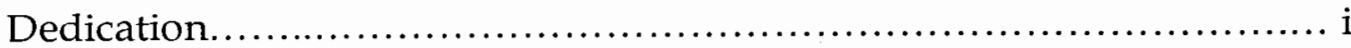

Acknowledgements...............................................

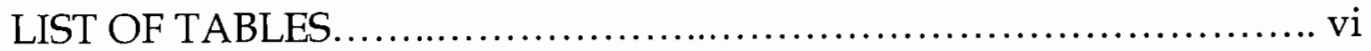

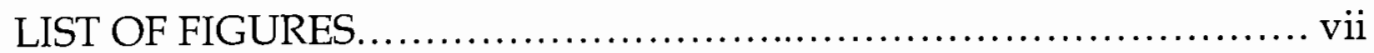

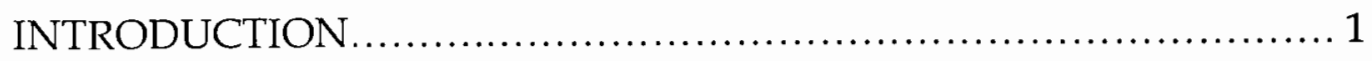

Reservoirs................................................. 1

Models........................................................ 2

Assumptions............................................. 8

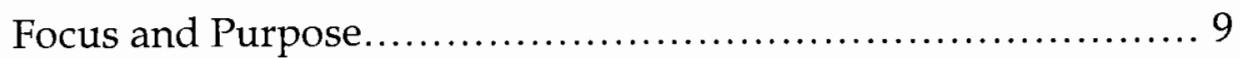

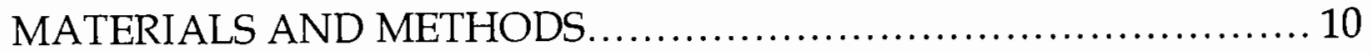

Reservoirs..................................................... 10

Field methods.................................................. 18

Laboratory Methods........................................ 23

Field Sampling Quality control.............................. 28

Laboratory quality control................................. 30

RESULTS ...................................................... 31

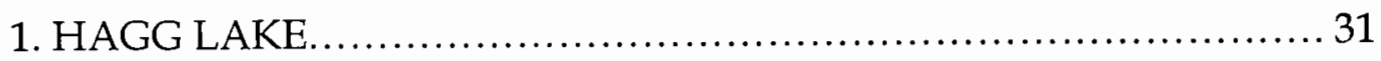

a) Physical Factors.......................................... 31

b) Chemical factors ........................................... 47 
c) Biological factors........................................ 70

2. BARNEY RESERVOIR ......................................... 86

a) Physical Factors.......................................... 86

b) Chemical factors........................................ 102

c) Biological factors........................................ 124

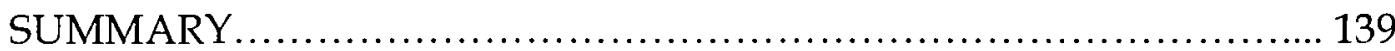

Hagg Lake..................................................... 141

Barney Reservoir....................................... 144

DISCUSSION .......................................................... 152

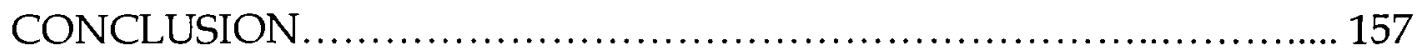

REFERENCES........................................................ 174

APPENDIX A. LABORATORY PROCEDURES FOR WATER CHEMISTRY, CATIONS AND CHLOROPHYLL-A ANALYSIS........................ 179

Guidelines for the handling of samples (Jones, 1998):............. 179

Laboratory Procedures:................................... 180

Total Nitrogen:............................................ 182

Nitrate+Nitrite Nitrogen:..................................... 183

Ammonium Nitrogen:....................................... 186

Total Phosphorus:........................................ 187

Soluble Reactive Phosphorus:............................... 189

Dissolved Silica................................................ 191 
Major Cations: Mg, Na, Ca and K........................... 193

Chlorophyll-a.............................................. 194

APPENDIX B. PLANKTON COUNTING METHODS.................. 197 


\section{LIST OF TABLES}

Table 1. Reservoir and Watershed Data

Table 2. Sampling dates, number of days between samples, and station

depths

Table 3. Chemical analysis methods and calculation methods 26

Table 4. Dominant Phytoplankton species in Hagg Lake $(\mu \mathrm{m} / \mathrm{ml})$ 71

Table 5. Dominant Zooplankton species in Hagg Lake $(\mu \mathrm{m} / \mathrm{ml}) \ldots \ldots \ldots \ldots . .76$

Table 6. Dominant Phytoplankton species in Barney Reservoir $(\mu \mathrm{m} / \mathrm{ml}) \ldots 125$

Table 7. Dominant Zooplankton species in Barney Reservoir $(\mu \mathrm{m} / \mathrm{ml}) \ldots . .129$

Table 8a. Descriptive statistics of Hagg Lake Data....................... 163

Table 8a. Descriptive statistics of Hagg Lake Data (cont.)................. 164

Table 8b. Hagg Lake Epilimnetic Data................................. 165

Table 9a. Descriptive statistics of Barney Reservoir Data.................. 168

Table 9b. Barney Reservoir Epilimnetic Data.......................... 170

Table 10. Anion Data from CCAL (Cameron Jones, 1998).................. 173 


\section{LIST OF FIGURES}

Figure 1. Reservoir Conceptual Model ....................................................... 6

Figure 2.General location of the reservoirs in the State of Oregon .................12

Figure 3.Hagg Lake and Barney Reservoir watersheds................................12

Figure 4. Hagg Lake aerial picture (US Geological Service, 1990) .................15

Figure 5. Barney Reservoir aerial picture (US Geological Service, 1980) .......17

Figure 6. Hagg Lake. Water elevation and precipitation (data from TVID, 1999)

Figure 7. Water inflows and outflows in Hagg Lake (data from TVID, 1999)

Figure 8. Hagg Lake. Hydraulic Mean Residence Time (Years). 34

Figure 9. Hagg Lake. Water, Epilimnion, Secchi and Photic Zone Depths....35

Figure 10. Hagg Lake. Epilimnetic DO, Temperature and Chlorophyll-a.....37

Figure 11. Hagg Lake. Time-depth graph of Temperature $\left({ }^{\circ} \mathrm{C}\right)$ 38

Figure 12. Hagg Lake. Temperature profiles from 9/15/1998 to

$10 / 28 / 1998$

Figure 13a. Hagg Lake. Time-depth graph of Dissolved Oxygen (mg/L)....41

Figure 13b. Hagg Lake. Time-depth graph of Dissolved Oxygen (\% Sat) .....42

Figure 14. Hagg Lake. Secchi and Photic depth..............................................43

Figure 15. Hagg Lake. Time-depth graph of Turbidity (NTU) ........................46

Figure 16. Hagg Lake. Time-depth graph of $\mathrm{pH}$ 
Figure 17a. Hagg Lake. Time-depth graph of Conductivity $(\mu \mathrm{S} / \mathrm{cm})$ 50

Figure 17b. Hagg Lake. Conductivity profiles from July and October 1998.51

Figure 18. Hagg Lake. Time-depth graph of Redox Potential (mV) 53

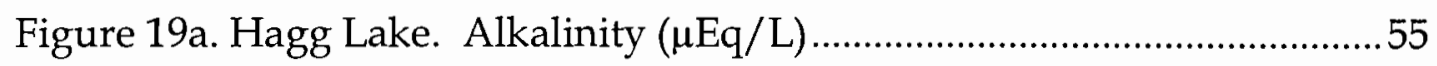

Figure 19b. Hagg Lake. Dissolved Inorganic Carbon (mg C/L) ....................55

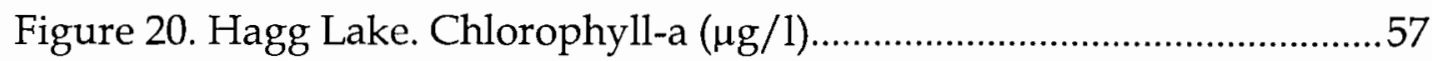

Figure 21. Hagg Lake. Epilimnetic Nitrogen species in $\mu \mathrm{g} / \mathrm{L}$........................59

Figure 22. Hagg Lake. TP and Soluble Reactive Phosphorus in $\mu \mathrm{g} / \mathrm{L}$...........61

Figure 23. Hagg Lake. Silica(mg/1) and Bacillariophycea biovolumes ..........62

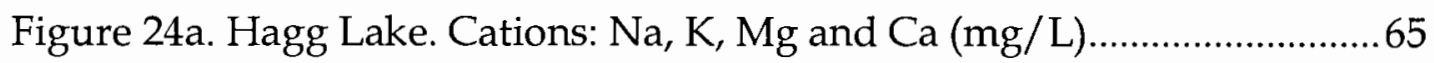

Figure 24b. Hagg Lake. Anions: $\mathrm{Cl}$ and SO4 (mg/L) ...................................... 65

Figure 25. Hagg Lake. Seasonal epilimnetic variations in Trophic State

Indices

Figure 26. Hagg Lake. TN:TP and Si:TP Nutrient Ratios .............................69

Figure 27. Hagg Lake. Dominant Phytoplankton Species ..............................72

Figure 28. Hagg Lake. Total colonial vs. individual phytoplankton species.74

Figure 29. Hagg Lake. Dominant Zooplankton Species .77

Figure 30. Hagg Lake. Predator vs. Non-predatory Zooplankton

Biovolumes .78

Figure 31a. Hagg Lake. Calanoids and eucladocerans biovolumes. .79

Figure 31b. Hagg Lake. Dominant Rotifers and protozoans 80 
Figure 32a Hagg Lake. Shannon-Weiner Species Diversity Index

Figure 32b Hagg Lake. Normalized (Diversity) Evenness .............................. 85

Figure 33. Barney Reservoir and its watershed. (USGS Maps) ........................ 87

Figure 34a. Barney R. Water elevation vs. precipitation, and storage versus

Releases

Figure 34b. Barney Reservoir Hydraulic Mean Residence Time in Years...... 90

Figure 35. Barney Reservoir. Epilimnion, Secchi and Photic depths ............. 91

Figure 36a. Barney Reservoir. Time-depth graph of Temperature $\left({ }^{\circ} \mathrm{C}\right)$.........93

Figure 36b. Barney Reservoir. Temperature profiles from July to September

1998 .94

Figure 37a. Barney Reservoir. Time-depth graph of Dissolved Oxygen

$(\mathrm{mg} / \mathrm{L})$ 96

Figure 37b. Barney R. Time-depth graph of Dissolved Oxygen (\% Sat) ........97

Figure 38. Barney Reservoir. Secchi and Photic depth. .99

Figure 39. Barney Reservoir. Time-depth graph of Turbidity (NTU)......... 101

Figure 40. Barney Reservoir. Time-depth graph of $\mathrm{pH}$................................104

Figure 41. Barney Reservoir. Time-depth graph of Conductivity $(\mu \mathrm{S} / \mathrm{cm}) 105$

Figure 42. Barney Reservoir. Time-depth graph Redox Potential (mV)......106

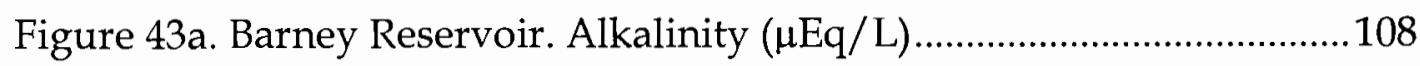

Figure 43b. Barney Reservoir. Dissolved Inorganic Carbon (mg C/L) .......109

Figure 44. Barney Reservoir. Chlorophyll-a $(\mu \mathrm{g} / \mathrm{L})$..................................... 111 
Figure 45. Barney Reservoir. Total Nitrogen $(\mu \mathrm{g} N / \mathrm{L})$.

Figure 46. Barney Reservoir. Nitrate+nitrite and Ammonium ( $\mu$ g N/L) ...113

Figure 47. Barney Reservoir. T P and SRP ( $\mu \mathrm{g}$ P/L) ..................................115

Figure 48. Barney Reservoir. Silica (mg/L) ...........................................116

Figure 49. Barney Reservoir. Cations: $\mathrm{Na}, \mathrm{Ca}, \mathrm{Mg}$ and $\mathrm{K}$ (in mg/L) ...........118

Figure 50. Barney Reservoir. Seasonal Trophic State Indices...................... 121

Figure 51. Barney Reservoir. TN:TP and Si:TP Nutrient Ratios .................123

Figure 52. Barney Reservoir. Dominant Phytoplankton Species ................. 126

Figure 53. Barney Reservoir Total Colonial vs. Individual Species .............127

Figure 54. Barney Reservoir total biovolumes of phytoplankton and zooplankton

Figure 55. Barney Reservoir Dominant Zooplankton Species ....................130

Figure 56a. Barney Reservoir zooplankton, by feeding groups

(biovolumes) 131

Figure 56b. Barney Reservoir Herbivore Zooplankton 132

Figure 57. Barney R. Total biovolumes of phytoplankton and herbivore zooplankton

Figure 58a. Barney Reservoir Shannon-Weiner Species Diversity Index....136

Figure 58b. Barney Reservoir Normalized (Diversity) Evenness 138

Figure 59. The Plankton Ecology Group Model.... .148

Figure 60a. Selected microphotographs of Hagg Lake phytoplankton 149 
Figure $60 \mathrm{~b}$. Selected microphotographs of Hagg Lake zooplankton...........150

Figure 61. Selected microphotographs of Barney R. Plankton....................151 


\section{INTRODUCTION}

\section{$\underline{\text { Reservoirs }}$}

Compared to natural lakes, man-made reservoirs are relatively new features of the environment. The reasons for the existence of reservoirs are utilitarian: to control floods, and to store water for irrigation etc. However, the operation and management of a reservoir are not arbitrary; social and physical or natural constraints regulate the range of their operations. Some natural constraints on their operation include the finite amount of water entering the reservoir and the storage capacity of the dam structure, and social constraints manifest themselves as laws and operational procedures to maintain a given water flow downstream, to maintain a suitable capacity in reservoirs for drinking water and to avoid damage to the dam structure and downstream areas.

The types and amounts of nutrients and sediment carried to the reservoir by upland streams will reflect land use practices within the watershed or drainage basin. Nutrients and sediment loadings will be the governed by natural and social constraints, resulting in a reservoir that will exhibit individual characteristics such as seasonal trophic and turbidity levels. These attributes will change according to a yearly sequence of meteorological events reflecting the climatic character of the larger 
geographical area. At the local level, these events together with the action of sedimentary and transport processes will have an impact on the biological and physico-chemical dynamics that occur within the reservoir (Thornton et al., 1990).

Limnological studies of reservoirs are time consuming and difficult to conduct owing to their "lake-river" nature (Thornton et al., 1990). Ryder (1978) described reservoirs as a distinct category of ecosystems retaining the characteristics of lotic and lentic environments. This hybrid nature is exemplified by the coexistence and overlap of many processes that characterize rivers and lakes. Transport and sedimentary processes create distinct riverine, transitional and lacustrine zones, and material gradients that extend from headwaters to dam structures (Thornton et al., 1990). The effect of these processes is felt throughout the length of reservoirs and take the form of pulses of nutrients and suspended materials (Thornton et al., 1990).

\section{$\underline{\text { Models }}$}

A conceptual model of a theoretical reservoir was developed for this study. This conceptual model is based on a combination of the approaches of the merological and holological methods of study. This model is limited in scope and does not include all the losses, inputs and other factors. Most ideas 
and relationships used to create this model originated from Thornton et al. (1990).

There are various theoretical models that deal directly or indirectly with the plankton dynamics. Tilman (1982) proposed an equilibrium theory of competition for limiting resources (consumer-resource theory), and tried to explain the role of competition in the emergence of diversity. This theory was not applied to this study because the data obtained was from nonmanipulated, non-experimental fieldwork. Reynolds (1996) proposed a demographic approach (CS R model) to interpret the interactions of the phytoplankton. However, Reynolds (1996) approach could not be applied to this study, as it still does not incorporates the zooplankton dynamics or defines the place of predation in his model. The PEG (Sommer et al. 1986) model summarizes the plankton succession in a 'generic' lake through twenty-four verbal statements. Because these statements depict a generalized phytoplankton - herbivorous zooplankton dynamics, they were tested on how well they explained the plankton dynamics in the lacustrine zone of a reservoir.

Thus, for this study, the PEG and the conceptual models were used as the basis to understand the dynamics of the abiotic and the biotic elements and to test its suitability in explaining the plankton dynamics of reservoirs. 


\section{Conceptual Model}

In developing this conceptual model, it was assumed that the coarsescale factors such as land use practices, watershed geomorphology, the meteorology and climate of the area are the components that give a reservoirs its initial character (Thornton et al., 1990).

In this conceptual model, the transport and sedimentary processes are affected by the residence times and the amount and kinds of inflows and outflows. These processes help define the extent of the longitudinal zonation (riverine, transitional and lacustrine zones) and gradients of dissolved matter (Thornton et al., 1990). For example, extremely short residence times would eliminate pelagic phytoplankton by causing cell washout rates greater than phytoplankton reproduction rates (Thornton et al., 1990). Wind mixing interactions will depend on water elevation (or depth), basin shape and shoreline development, and will affect the dilution and settling of sediments and nutrients entering through the inflows. Turbidity, particulate matter and nutrient availability will interact with the physical processes described above and impact the standing crop of phytoplankton (Thornton et al., 1990). The phytoplankton (and bacteria) in turn will start the trophic chain by supporting herbivorous zooplankton, predatory zooplankton, insects, planktivorous fish and other vertebrates. 
Although the dynamics and characteristics of reservoirs appears complex and difficult to study, this appearance vanishes as soon as one realizes that a methodical approach, coupled with some awareness of the interacting factors that make a reservoir, can be used to partition or select one particular dimension or problem of interest. Once this dimension is selected, the elements left out can still be referenced to aid in explaining the changes observed. The conceptual model developed here served to identify some of the many dimensions and factors that define a theoretical reservoir. The dimension of interest chosen for this study was the dynamics of the planktonic successions from the June 1998 to early July 1999, and the place that these successions occupy within the interacting components that make up Hagg Lake and Barney Reservoir (Figure 1).

\section{The Plankton Ecology Group (PEG) Model}

The PEG (Sommer et al. 1986) model is composed of 24 verbal statements. Statements 1 to 5 describe the planktonic spring succession and is summarized as follows: increases in light and availability of nutrients permits the growth of small centric diatoms and cryptomonads which in turn support the growth of large herbivorous zooplankton until their grazing pressure on phytoplankton is such that their elimination creates a period or phase of 'clear water'. 


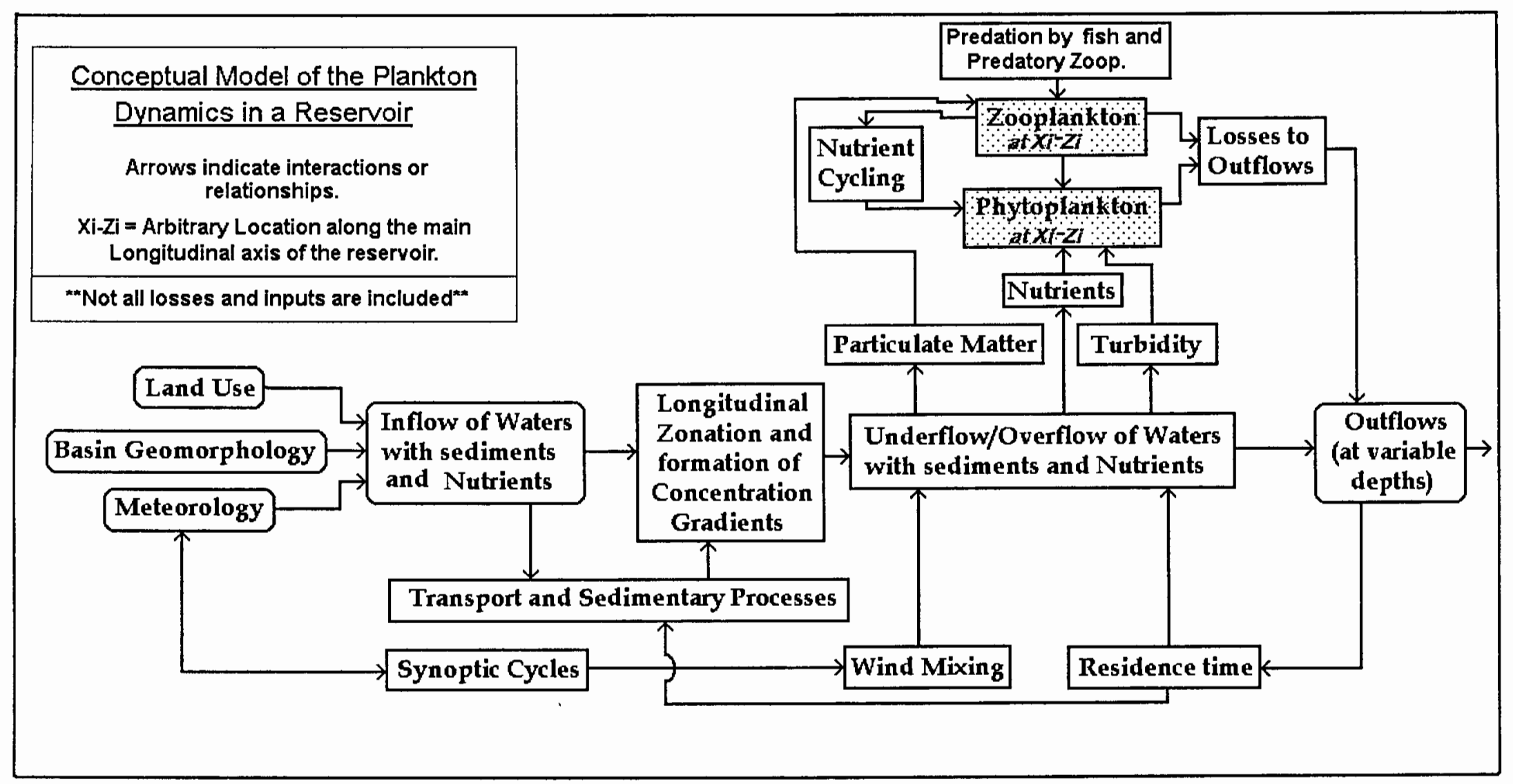

Figure 1. Reservoir Conceptual Model. 
The statements 6 to 16 of the PEG model describe the summer planktonic succession and are summarized as follows: decreases in herbivore zooplankton due to food limitation and low fecundity and fish predation allow the phytoplankton populations to bounce back, so that phosphorus is almost depleted, and the small zooplankton populations begin to increase. The two groups decrease as nutrients are consumed. Dinoflagelates or Cyanophytes begin to dominate the phytoplankton and are replaced later by nitrogen fixing Cyanophytes if nitrogen is depleted. At this point in late summer, large bodied zooplankton gives way to smaller zooplankton. The herbivore zooplankton attains high diversity by partitioning the available food supply. Temperature affects the zooplankton composition and its fluctuations.

The statements 17 to 20 of the PEG model describe the fall planktonic succession and are summarized as follows: physical changes caused by the overturn or mixing of the water column favor species adapted to low light and continuous mixing disturbance and low fish predation favors big-bodied zooplankton. The statements 21 to 24 of the PEG model describe the winter planktonic succession and are summarized as follows: low light and its consequence the low algal biomass combined with low temperatures signals the start of the diapause period in some zooplankton or lowers the fecundity in another zooplankton species. 


\section{Assumptions}

The tentative assumptions and expectations that initiated the study were the following:

a) The close proximity between the two reservoirs $(15 \mathrm{Km})$, the similar land use practices, vegetation cover, and meteorological conditions in their watersheds imply that similar species successions might occur, and that the effects of the small differences in land use might be evident in the structure of the successions.

b) The synoptic events occurring during the rainy season of the northwest corner of the state of Oregon will cause increases in sediments and organic loadings to the reservoirs. As these inputs reach the lacustrine zone, they will cause changes in the success ional composition and dominance of planktonic species.

c) The impacts of the outflow rates in these reservoirs will be measured by the changes imposed on the hydraulic residence times of the waters, and on the changes of the depth profiles of the physical and chemical variables measured. The depth of the water withdrawals could be crucial in understanding the effects of these impacts.

d) The PEG (Sommer et al. 1986) model could explain the plankton dynamics in the lacustrine zone of a reservoir. 


\section{Focus and Purpose}

This study focuses on the lacustrine zone of Hagg Lake and Barney Reservoir, particularly on the epilimnetic layer, at $1 \mathrm{~m}$ below the water surface at the sampling stations. Other samples were taken at the metalimnion (thermocline) and the hypolimnion depths, and profiles were created from measurements at different depths of temperature, dissolved oxygen, $\mathrm{pH}$, turbidity and conductivity. The plankton studied in this thesis includes only microscopic algae and microscopic zooplankton living in the pelagic zone.

The purpose of the study was to identify the succession dynamics of the planktonic species in the reservoirs, and test the suitability of the PEG model to explore the relationships between these successions and the physical and chemical variables measured from June 1998 to July 1999. 


\section{MATERIALS AND METHODS}

This section summarizes reservoir data, field sampling and the laboratory analysis methods. Detailed laboratory analytical procedures for water chemistry and chlorophyll-a are given in Appendix A. The phytoplankton and zooplankton sampling and counting procedures are given in Appendix B.

\section{$\underline{\text { Reservoirs }}$}

The reservoirs studied were Hagg Lake and Barney Reservoirs. These two reservoirs are located in the northwest corner of the State of Oregon (Figure 2).

\section{Reservoir:}

Latitude:

Longitude:

Surface Area:

Shoreline:

Watershed Area:

Deepest Point ${ }^{1}$ :

Elevation of intake struct. 1:

Max. Water Elev. ${ }^{1}$ :

Max. Water Depth (Winter):
Hagg Lake

$\mathrm{N} 45^{\circ} 28^{\prime} 20^{\prime \prime}$

W123ำ $12^{\prime} 15^{\prime \prime}$

$4.72 \mathrm{Km}^{2}$

$18.3 \mathrm{Km}$

$99.8 \mathrm{Km}^{2}$

$60.96 \mathrm{~m}$

$69.8 \mathrm{~m}$

$93 \mathrm{~m}$

$32 \mathrm{~m}$
Barney Reservoir ${ }^{2}$

$\mathrm{N} 45^{\circ} 26^{\prime \prime} 42^{\prime \prime}$

$\mathrm{W} 123^{\circ} 23^{\prime} 40^{\prime \prime}$

$2.82 \mathrm{Km}^{2}$

$7.7 \mathrm{Km}$

$14 \mathrm{Km}^{2}$

$467 \mathrm{~m}$

$477 \mathrm{~m}$

$497.9 \mathrm{~m}$

$31 \mathrm{~m}$

Table 1. Reservoir and Watershed Data. 
Reservoir:

Min. Water Storage:

Max. Water Storage:

Mean Water Residence Time:

\% Forest Cover ${ }^{3}$ :

$\%$ Shrubs/recent timber harv. ${ }^{3}$ :

$\%$ Water ${ }^{3}$ :

$\%$ Agricultural $^{3}$ :

$\%$ Meadows 3 :
Hagg Lake

$62,996,625 \mathrm{~m}^{3}$

$257,669,441 \mathrm{~m}^{3}$

3.39 years

82.2

4.7

4.3

3.5

5.1
Barney Reservoir ${ }^{2}$

$5,402,511 \mathrm{~m}^{3}$

$68,796,025 \mathrm{~m}^{3}$

2.07 years

93

0.6

5.4

$\mathrm{n} / \mathrm{a}$

$\mathrm{n} / \mathrm{a}$

1. - Measured in meters above mean sea level ( $m$ a. m. s. l.), from Knutson 1993. 2. Measured at $487.6 \mathrm{~m}$ a.m.s.l. 3. -This data is from the Tualatin River Watershed Council, and publicly available from USGS and other agencies.

Table 1. Reservoir and Watershed Data (Continued).

\section{Hagg Lake:}

Hagg Lake, also known as Scoggins reservoir, is located $10 \mathrm{Km}$ southwest of Forest Grove, Washington County, Oregon, and it is part of the Tualatin River watershed. Hagg Lake is located in the foothills of the Coast Range, within the Willamette valley ecoregion.

Hagg Lake is a multi-purpose reservoir built by the U.S. Bureau of reclamation in 1972 and put into service in 1974 . This reservoir was formed by damming Scoggins Creek, a tributary on the upper end of the Tualatin River, with a $45.75 \mathrm{~m}$ high earth-filled structure (Johnson et al., 1985). The intake structure is located at $69.8 \mathrm{~m}$ a. m. s. l. to the southwest of the 


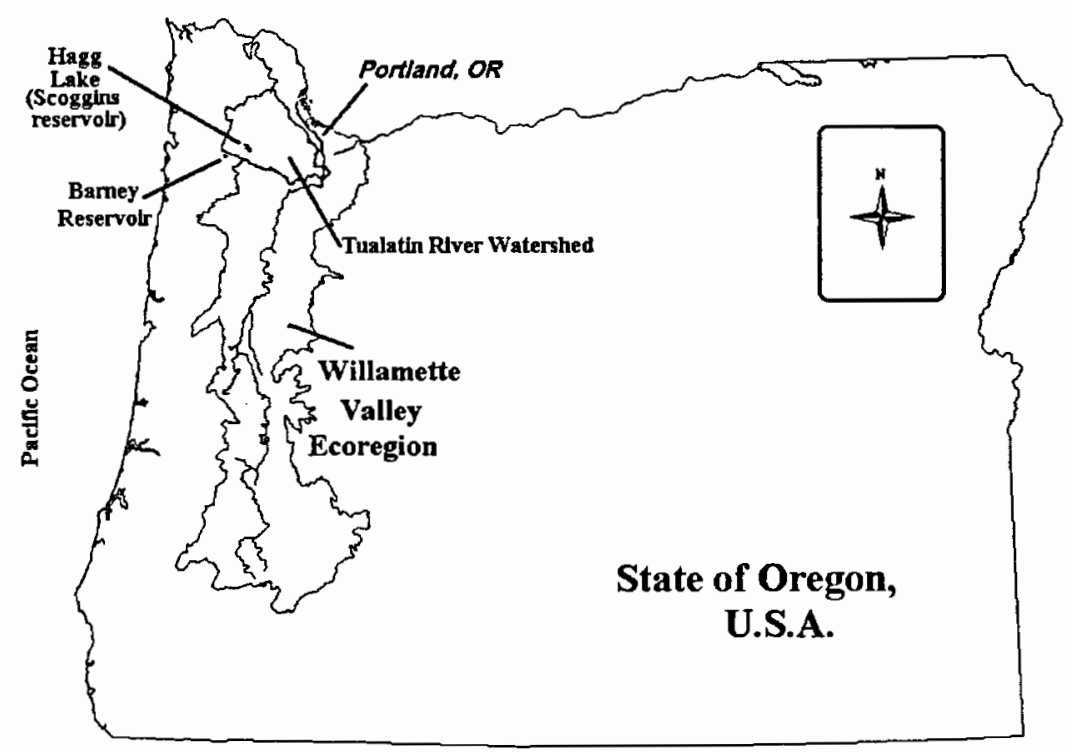

Figure 2.General location of the reservoirs in the State of Oregon.

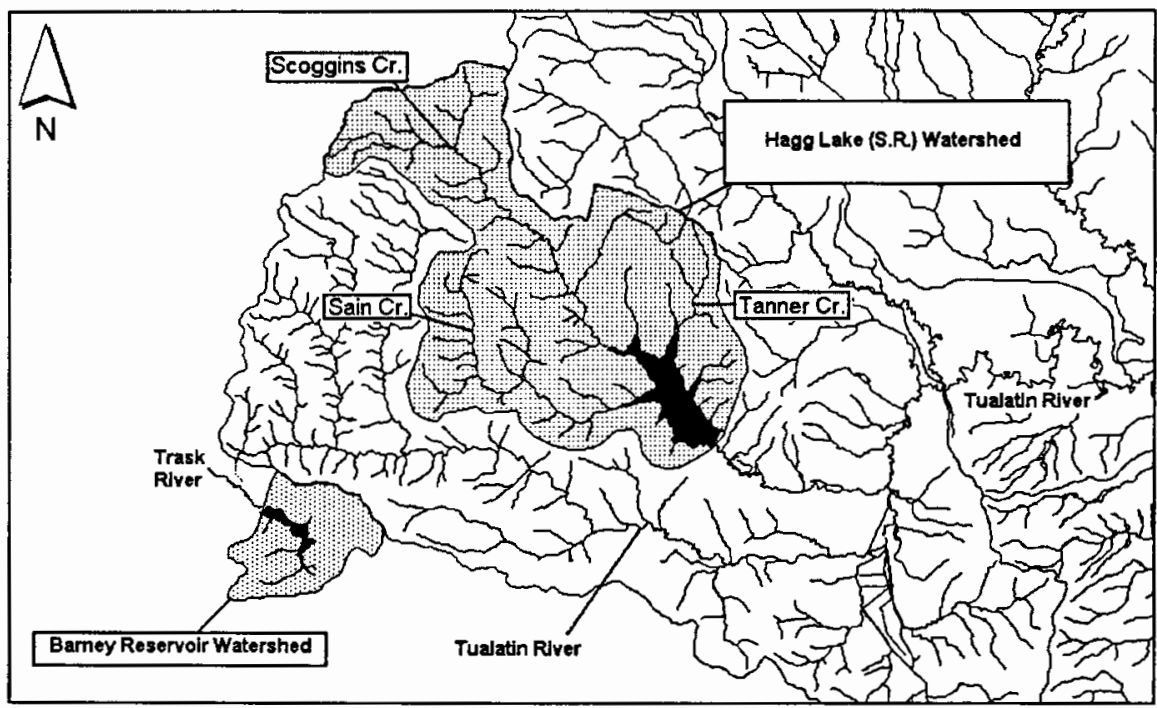

Figure 3.Hagg Lake and Barney Reservoir watersheds. 
spillway structure (Knutson, 1993). The depth of the outflow intake structure from the water surface reached $23.1 \mathrm{~m}$ at the maximum water elevation.

This reservoir is owned by the Bureau of Reclamation and operated by the Tualatin Valley Irrigation District (TVID) of Washington County. The Tualatin Valley Irrigation District uses it as a source of drinking water, as a recreational area from spring through fall, to control the water flow of the Tualatin River (Figure 4).

The watershed of Hagg Lake has an area of $99.8 \mathrm{Km}^{2}$, and it is drained by three main creeks: Scoggins Creek, that has a network of streams $24.6 \mathrm{Km}$ in length and a main stem of $8.5 \mathrm{Km}$; Tanner Creek, that has a network of streams $5.3 \mathrm{Km}$ in length, and a main stem of $3 \mathrm{Km}$; and Sain Creek that has a network of $16.4 \mathrm{Km}$ in length and a main stem of $5 \mathrm{Km}$ (Figure 3). The average contribution of Scoggins Creek to the total inflows of water is $60.5 \%$, the contribution of Tanner Creek is 3.9\% and the contribution Sain Creek of is $35.6 \%$.

The total measured precipitation in Hagg Lake from May 1, 1998 to May 1, 1999 was of $19,992 \mathrm{~mm}$. The average daily hydraulic residence time on the same periods was 3.4 years, with a maximum residence time of 22 years (5/2/1998) and a minimum residence time of 40 days (2/9/1999). 
This reservoir has a maximum storage capacity of $257,669,441 \mathrm{~m}^{3}$ of water. The pool is lowered during the dry summer months by an average of $6.7 \mathrm{~m}$, and filled during the winter months. The drainage basin covers an area of $99.8 \mathrm{Km}^{2}$ (Figure 2).

The watershed is covered mostly by thick soils of clay and silt overlying bedrock that is a mixture of sandstone and older volcanic rocks (Johnson et al., 1985). The forest vegetation of the watershed is composed of western hemlock and Douglas fir (Pseodotsuga menziesii, Tsuga heterophylla) that covers approximately $82.2 \%$. Mountain snowberry (Symphoricarpus sp.) and Mountain sagebrush (Artemisia sp.) cover approximately $4.7 \%$ of the watershed. Timber harvesting and livestock grazing and other agricultural activities take place in the watershed.

\section{Barney Reservoir}

J.W. Barney Reservoir is located $24 \mathrm{Km}$ southwest of Forest Grove, Washington County, Oregon (Figure 3), and $14.9 \mathrm{Km}$ from Hagg Lake. It is in the North fork of the Trask River, and it is part of the Trask River watershed of the Coast Range. The watershed of Barney Reservoir neighbors the Tualatin River watershed and straddles Washington and Yamhill Counties. An aqueduct is used to transfer water from Barney Reservoir to the Tualatin River. Initial construction of this reservoir was finished 1970 with an original capacity of $16,187,300 \mathrm{~m}^{3}$. In December 1977 , the height of 

Hagg Lake (Scoggins Reservoir)
photo courtesy of the US Geological Survey.

Image found at: hilp://4m.teraserver microsolt.coms

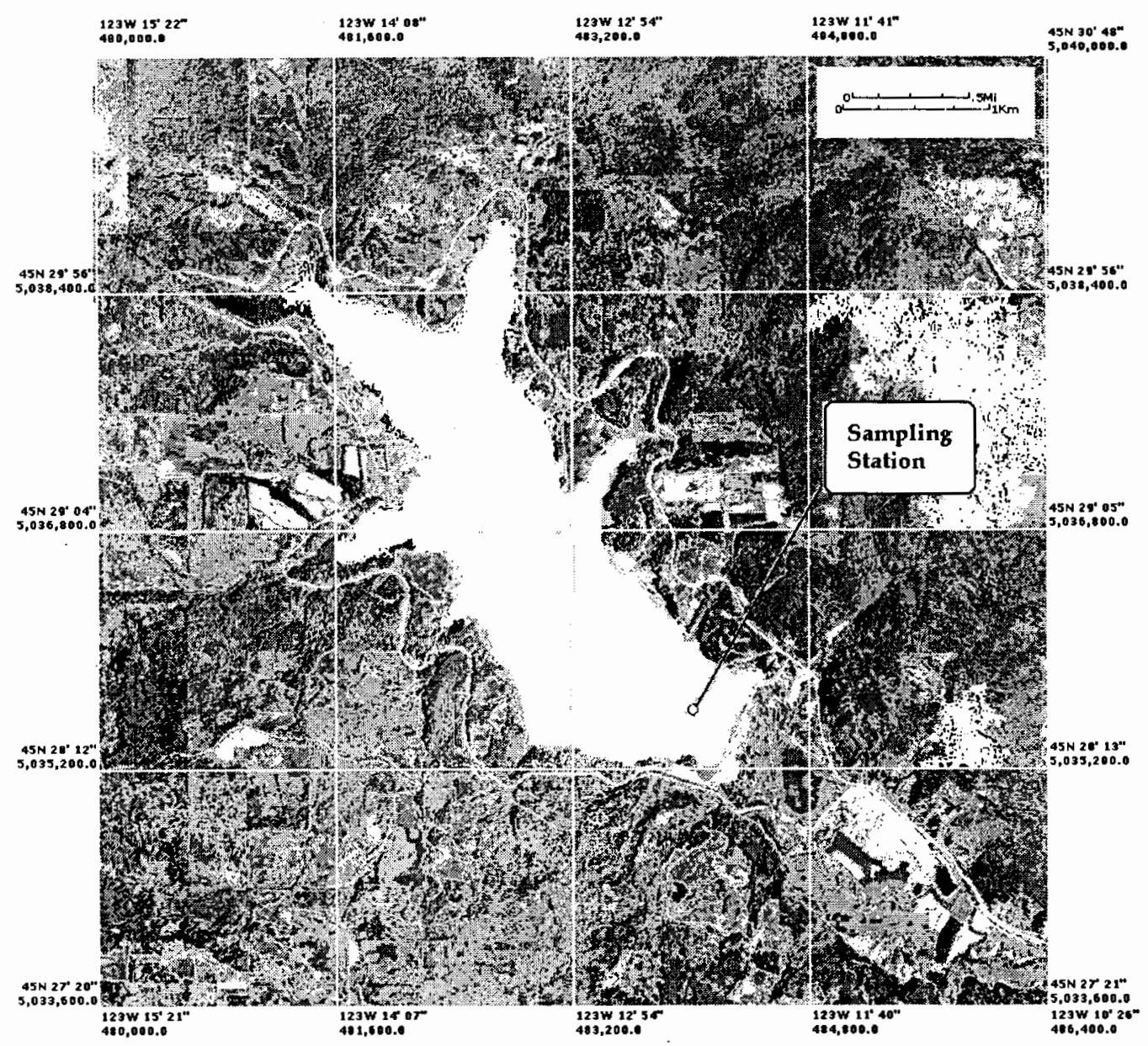

Figure 4. Hagg Lake aerial picture (US geological Service, 1990) 
the dam was increased (Karl Borg, Forest Grove Treatment Plant, personal communication) and the additional improvements were completed in 1999. By March 1999 it was able to hold 4.25 times the original volume $(68,796,025$ $\mathrm{m}^{3}$ ). This reservoir is used for stream flow control, and as a supplementary water source by the TVID (Figure 5).

The watershed of Barney Reservoir is fed by the upper $5 \mathrm{Km}$ of the North fork of the Trask River and its $3.8 \mathrm{Km}$ of shorter streams; the rest of the drainage network includes several smaller and intermittent streams. The drainage basin of Barney Reservoir covers an area of $14 \mathrm{Km}^{2}$. The watershed is largely covered by clay and silt soils over bedrock that is a mixture of tuffaceous sedimentary rocks and tuff (Walker and MacLeod, 1991).

The forest vegetation of the watershed is composed of western hemlock and Douglas fir (Pseodotsuga menziesii, Tsuga heterophylla) and it covers approximately $93 \%$ of the watershed. Human activities on the watershed of Barney Reservoir include timber harvesting and off-road vehicles recreation.

It is also important to note that due to recent increases in the storage capacity of the dam, the area covered by water, and the water depth and surface elevation also increased. Also, that during the study period, some of the roots and other organic debris from the vegetation that covered the inundated areas still remained on the ground. 


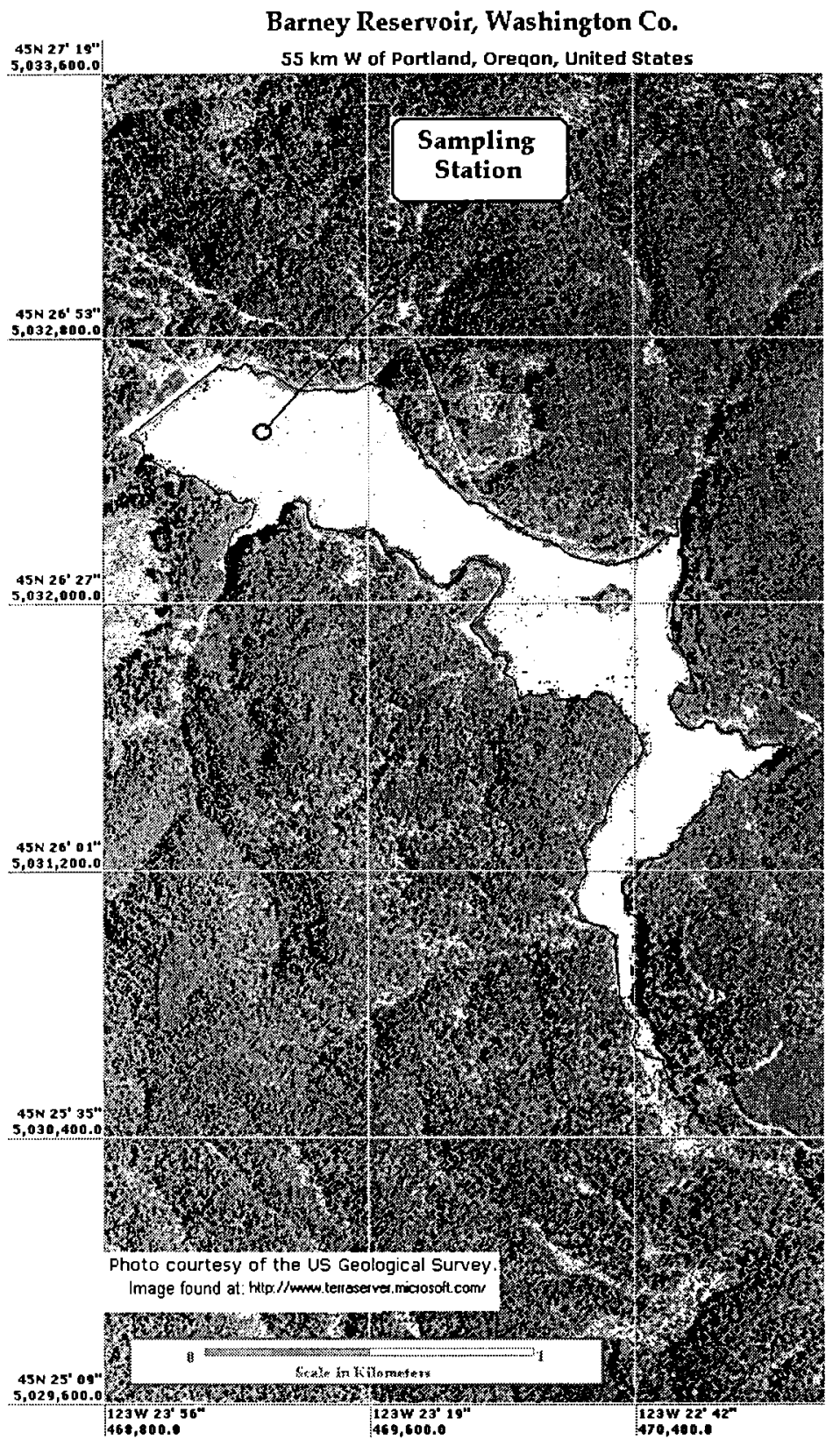

Figure 5. Barney Reservoir aerial picture (US geological Service, 1980) 


\section{Field methods}

Barney Reservoir and Hagg Lake were sampled twice a month during the summer and the fall 1998 and once monthly during the winter and spring of 1999. For the sampling dates see Table 2.

\begin{tabular}{|c|c|c|c|c|c|c|c|}
\hline \multicolumn{3}{|c|}{ Barney Reservoir } & \multicolumn{5}{|c|}{ Hagg Lake } \\
\hline $\begin{array}{l}\text { Sample } \\
\text { ID }\end{array}$ & Date & $\begin{array}{c}\text { Days From } \\
\text { Last Sampling }\end{array}$ & $\begin{array}{c}\text { Station } \\
\text { Depth (m) }\end{array}$ & $\begin{array}{c}\text { Sample } \\
\text { ID }\end{array}$ & Date & $\begin{array}{c}\text { Days From } \\
\text { Last Sampling }\end{array}$ & $\begin{array}{c}\text { Station } \\
\text { Depth }(m)\end{array}$ \\
\hline BS01 & $6 / 30 / 98$ & 0 & 21.23 & HS01 & $6 / 23 / 98$ & 0 & 29.5 \\
\hline BSO2 & $7 / 14 / 98$ & 14 & 22.6 & $\mathrm{HSO2}$ & $7 / 7 / 98$ & 14 & 30.3 \\
\hline BSO3 & $7 / 28 / 98$ & 14 & 20 & $\mathrm{HSO3}$ & $7 / 20 / 98$ & 14 & 31.4 \\
\hline BSO4 & $8 / 11 / 98$ & 14 & 17.2 & HSO4 & $8 / 4 / 98$ & 14 & 26.75 \\
\hline BS05 & $8 / 25 / 98$ & 14 & 13.5 & HSO5 & $8 / 18 / 98$ & 14 & 24.8 \\
\hline BSO6 & $9 / 8 / 98$ & 14 & 11.75 & HSO6 & $9 / 1 / 98$ & 14 & 27.5 \\
\hline BSO7 & $9 / 22 / 98$ & 14 & 10.9 & HSO7 & $9 / 15 / 98$ & 14 & 21.9 \\
\hline BS08 & $10 / 6 / 98$ & 14 & 9.8 & HSO8 & $9 / 29 / 98$ & 14 & 20 \\
\hline BSO9 & $10 / 20 / 98$ & 14 & 10.6 & HSO9 & $10 / 13 / 98$ & 14 & 22.1 \\
\hline BS10 & $11 / 3 / 98$ & 14 & 10.3 & HS10 & $10 / 28 / 98$ & 15 & 22.1 \\
\hline BS11 & $11 / 17 / 98$ & 14 & 10.4 & HS11 & $11 / 10 / 98$ & 13 & 20.8 \\
\hline BS12 & $12 / 10 / 98$ & 23 & 20.2 & HS12 & $12 / 3 / 98$ & 23 & 24.25 \\
\hline$B S 13$ & $1 / 12 / 99$ & 33 & 24.7 & HS13 & $1 / 19 / 99$ & 47 & 28.5 \\
\hline BS14 & $2 / 23 / 99$ & 42 & 27.55 & HS14 & $2 / 17 / 99$ & 28 & 29.3 \\
\hline BS15 & $3 / 23 / 99$ & 28 & 25.3 & HS15 & $3 / 16 / 99$ & 28 & 31.55 \\
\hline$B S 16$ & $4 / 21 / 99$ & 29 & 21.3 & HS16 & $4 / 14 / 99$ & 29 & 33.2 \\
\hline BS17 & $5 / 19 / 99$ & 28 & 23.1 & HS17 & $5 / 12 / 99$ & 28 & 33.5 \\
\hline BS18 & $6 / 7 / 99$ & 21 & 22.6 & HS18 & $5 / 26 / 99$ & 14 & 31.7 \\
\hline BS19 & $7 / 7 / 99$ & 28 & 21 & HS19 & $6 / 16 / 99$ & 21 & 32.45 \\
\hline
\end{tabular}

Table 2. Sampling dates, number of days between samples, and station depths. 


\section{Main station, depth and water levels}

The main stations for both reservoirs were located at least $300 \mathrm{~m}$ away from their respective dam structures, and where reservoirs were deepest. The station locations were chosen so as to locate the sampling station in the lacustrine zone of the reservoirs. The depths were measured with a small depth sounder (Humminbird ${ }^{\oplus}$, Wide Vision). The water elevation in Barney Reservoir was measured by reading the water elevation markers of the dam; the water elevation from Hagg Lake was obtained from the official daily measurements taken by the personnel in charge of the dam operations.

\section{Secchi depth and irradiance}

The Secchi depth was measured with a Secchi disk of $20 \mathrm{~cm}$ in diameter. The light intensity, in $\mu$ Einsteins $\mathrm{m}^{-2} \cdot \mathrm{s}-1$, was measured with a LICOR ${ }^{\circledR}$ spherical underwater sensor (No. SPQA 0275) that measured the photosynthetic active radiation (PAR). This sensor was connected by a cable to a LI-1000® data logger (LDL 2500). The rates of light extinction and the limits of the photic zone (depth where the light intensity measures $1 \%$ of the incoming light at 
the surface) were calculated from these measurements (Wetzel and Likens, 1991).

DO, turbidity, conductivity, temperature and $p H$

A temperature array or string of $\mathrm{Vemco}^{\circledR}\left(\mathrm{Minilog}^{\circledR}\right)$ temperature monitors was built by attaching $31 \mathrm{Vemco}^{\circledR}$ units to an aircraft cable $30 \mathrm{~m}$ long. After each trip, the temperature data were downloaded from the units through a Vemco $^{\circledR}$ optical computer interface.

Other physical and chemical variables were measured with a Hydrolab $^{\circledR} \mathrm{H} 2 \mathrm{O}$ multiprobe (SN25373) attached by a 25-meter cable to an SVR3-DL Surveyor $3^{\circledR}$ data logger (SN25371). Readings were taken at $0.1 \mathrm{~m}$, $0.5 \mathrm{~m}$ and then $1 \mathrm{~m}$ intervals until reaching the bottom of the reservoir or reaching $24.5 \mathrm{~m}$. For these variables a reservoir profile was created. The variables measured with the $\mathrm{Hydrolab}^{\circledR} \mathrm{H} 2 \mathrm{O}$ multiprobe were:

Temperature (degrees Celsius).

Dissolved oxygen $(\mathrm{mg} / \mathrm{L})$.

Conductivity $(\mu \mathrm{S} / \mathrm{cm})$.

Turbidity (NTU units).

pH units. 
Missing values (to $0.2 \mathrm{~m}$ above the bottom), were interpolated using the temperature data from the array or string of $\operatorname{Vemcos}^{\circledR}$ as a reference for the rates of change in the very few cases when the depth of the reservoirs was greater than $24.5 \mathrm{~m}$.

\section{Water samples for chlorophyll-a, nutrient analysis and alkalinity}

Water samples were from the epilimnion $(1 \mathrm{~m}$ below the water surface), the metalimnion (most likely point of the thermocline defined by the temperature profile measured by the $\mathrm{Hydrolab}^{\otimes}$ unit), and the hypolimnion ( $1 \mathrm{~m}$ above the bottom of the reservoirs). The metalimnion sample was taken whenever there was a thermocline (or more than sixty percent of the cases).

Water samples were collected with a vertical 3-liter Van Dorn bottle (Scott Instruments Inc.). The water samples were placed in $250 \mathrm{ml}$ Nalgene ${ }^{\circledR}$ bottles. These bottles had been acid soaked in the laboratory in a $4 \%$ hydrochloric acid bath (for at least 12 hours) and rinsed eight times with ultra pure deionized water.

For each sample, a $250 \mathrm{ml}$ dark high-density polyethylene (HDPE) Nalgene ${ }^{\circledR}$ bottle and four $250 \mathrm{ml}$ clear HDPE Nalgene ${ }^{\circledR}$ bottles were used. In the field, the HDPE bottles were rinsed with reservoir water at least twice, 
and then filled with water from the Van Dorn unit. The bottles were then placed in a cooler with ice.

Upon returning to shore, the sample in the dark bottle was filtered with a Nalgene ${ }^{\circledR}$ hand pump filtration set up and a glass microfiber filter (Whatman ${ }^{\circledR} \mathrm{GF} / \mathrm{F} 47 \mathrm{~mm}$ ). These filters were washed with deionized water and oven dried at $55^{\circ} \mathrm{C}$. for at least 48 hours. Filtration was always within two hours after sampling. The filtered sample was stored in a clean clear HDPE Nalgene ${ }^{\circledR}$ bottle for chemical analysis. Three drops of saturated $\mathrm{MgCO}_{3}$ were added to the filter, it was placed in a filter holder, wrapped in foil and placed in ice to be analyzed for chlorophyll-a.

Samples from the epilimnion, metalimnion and hypolimnion were analyzed for alkalinity. Alkalinity was measured in $\mathrm{mg} / \mathrm{L}$ of $\mathrm{CaCO}_{3}$ in the field, and in and $\mu \mathrm{Eq} / \mathrm{L}$ in the laboratory. The field method used was that of titration with color indicators (bromcresol green-methyl red and phenolphthalein). The laboratory method was the Gran titration (Wetzel and Likens, 1991). Dissolved inorganic carbon in $\mathrm{mg} \mathrm{C} / \mathrm{L}$ was derived from $\mathrm{pH}$ and Alkalinity data following the procedure described in Wetzel and Likens, (1991). 


\section{Phytoplankton and zooplankton samples}

Water samples for phytoplankton analysis were collected with the Van Dorn bottle. $2.5 \mathrm{ml}$ of Lugol's solution was added to the $250 \mathrm{ml}$ HDPE bottles marked for the phytoplankton samples to reach a $1 \%$ final concentration of Lugol's fixative. Once in the laboratory, the samples were stored in the dark, in a refrigerated room at $4^{\circ} \mathrm{C}$.

The zooplankton samples were collected with a folding plankton net of a diameter of $49 \mathrm{~cm}$. Depending on the amount of water in the sample, from 1 to $3 \mathrm{ml}$ of formalin ( $40 \%$ formaldehyde buffered with sodium acetate (Wetzel and Likens, 1991)), were added to preserve the organisms. Once in the laboratory, the samples were stored in the dark, in a refrigerated room at $4^{\circ} \mathrm{C}$

\section{Laboratory Methods}

Three of the 38 sets collected were submitted to the Cooperative Chemical Analytical Laboratory (CCAL) in Corvallis, Oregon for nutrient and major ion analysis. The CCAL is a laboratory established by the USDA Forest Service and the Department of Forest Science, Oregon State University. These samples are marked with an asterisk in the tables where they are included. The rest of samples were analyzed at Portland State University by the author. 


\section{Chemical analysis methods and calculation methods}

Concentration of the following analytes were measured: total nitrogen, nitrate+nitrite, ammonium, total phosphorus, soluble reactive phosphorus, dissolved silica, dissolved magnesium, dissolved sodium, dissolved calcium and dissolved potassium. The units of measurement were $\mu \mathrm{g} / \mathrm{L}$, except in the case of silica and the cations that were measured in

$\mathrm{mg} / \mathrm{L}$. The samples were frozen as soon after they were collected, and thawed before the analysis; the handling of the samples followed the guidelines described in the AHPA, 1988, as modified in the CCAL Guidelines (Jones, 1998). Table 3 describes the Chemical analysis methods and calculation methods used.

\section{Trophic State Index (TSI)}

The trophic state indices proposed by Carlson (1977) were used here to classify Hagg Lake and Barney Reservoir. According to Carlson (1977) and Johnson (1985), oligotrophic lakes fall within the range of 20 to 35 TSI units, mesotrophic lakes in the range of 35 to 50 TSI units, and eutrophic lakes in the range of 51 to 65 TSI units, with the biomass doubling every 10 TSI units. 


\section{$\underline{\text { Plankton counting and identification }}$}

Dominant organisms were identified to species, and the rest to genus.

A minimum of 400-500 cells was counted from each sample using a

Nannoplankton (phytoplankton) and a Sedgwick-Rafter cell (Zooplankton). 


\begin{tabular}{|c|c|c|}
\hline Total Nitrogen (TN) & $\begin{array}{l}\text { Alkaline persulfate digestion } \\
\text { method, finished with the cadmium } \\
\text { reduction method }\end{array}$ & $\begin{array}{l}\text { Carpenter, } 1994 . \\
\text { Ameel et al., } \\
1993 .\end{array}$ \\
\hline $\begin{array}{l}\text { Nitrate+nitrite } \\
\text { Nitrogen }\left(\mathrm{NO}_{2}+\mathrm{NO}_{3}\right)\end{array}$ & Cadmium reduction method & $\begin{array}{l}\text { Jones, } 1984 . \\
\text { Carpenter, } 1994 .\end{array}$ \\
\hline $\begin{array}{l}\text { Ammonium Nitrogen } \\
\left(\mathrm{NH}_{4}-\mathrm{N}\right)\end{array}$ & Phenol-hypochlorite method & $\begin{array}{l}\text { Wetzel and } \\
\text { Likens, } 1991 .\end{array}$ \\
\hline $\begin{array}{l}\text { Total Phosphorus } \\
\text { (TP) }\end{array}$ & $\begin{array}{l}\text { Alkaline persulfate digestion } \\
\text { method, finished with the ascorbic } \\
\text { acid method. }\end{array}$ & $\begin{array}{l}\text { Carpenter, } 1994 . \\
\text { Ameel et al., } \\
1993 .\end{array}$ \\
\hline $\begin{array}{l}\text { Soluble reactive } \\
\text { phosphorus (SRP) }\end{array}$ & Ascorbic acid method & $\begin{array}{l}\text { Wetzel and } \\
\text { Likens, } 1991 .\end{array}$ \\
\hline $\begin{array}{l}\text { Cations }(\mathrm{K}, \mathrm{Mg}, \mathrm{Ca} \\
\text { and } \mathrm{Na})\end{array}$ & Flame absorption technique & $\begin{array}{l}\text { Beaty and } \\
\text { Kerber, } 1993 .\end{array}$ \\
\hline $\begin{array}{l}\text { Silicon as Dissolved } \\
\text { Silica }\left(\mathrm{SiO}_{2}\right)\end{array}$ & Molybdate method & $\begin{array}{l}\text { Wetzel and } \\
\text { Likens, } 1991 .\end{array}$ \\
\hline Chlorophyll a & Phaeophytin-corrected method & $\begin{array}{l}\text { Dagget, } 1994 \\
\text { Axler and Owen, } \\
1994 .\end{array}$ \\
\hline $\begin{array}{l}\text { Phytoplankton and } \\
\text { zooplankton counts }\end{array}$ & $\begin{array}{l}\text { Sedimentation and counting of } \\
400-500 \text { cells. }\end{array}$ & $\begin{array}{l}\text { Wetzel and } \\
\text { Likens, } 1991 . \\
\text { APHA, } 1998\end{array}$ \\
\hline Trophic state indices & $\begin{array}{l}\text { Chlorophyll-a, Secchi depth and } \\
\text { Phosphorus indices. }\end{array}$ & Carlson, 1977. \\
\hline Diversity Indices & Shannon-Weiner index & $\begin{array}{l}\text { Shannon and } \\
\text { Weaver, } 1949 .\end{array}$ \\
\hline
\end{tabular}

Table 3. Chemical analysis methods and calculation methods 


\section{Phytoplankton counting and identification:}

Cell were counted and measured to calculate their approximate biovolumes based on simple geometric formulae (Wetzel and Likens, 1991). Cell volumes (biovolumes) were used to achieve a better evaluation of the cellular biomass of the species present in the samples and their importance in the successions (Wetzel and Likens, 1991). The sources for the identification of diatoms were Vinyard (1979), Weber (1971), Patrick and Reimer (1966) and Krammer and Lange-Bertalot (1991). The sources for the identification of the other algae were West and West (1971), Prescott (1962), Prescott (1978), Lewis and Britton, (1971), Patrick and Reimer (1966), Huber-Pestalotz (1941), Smith (1950) and Contant and Duthie (1978).

\section{Zooplankton counting and identification:}

Individuals were counted and measured. The average calculated biovolume were compared to published biovolumes, and in some cases biovolumes from the literature were used to calculate the final average biovolume per species (Wetzel and Likens, 1991), (Nauwerck, 1963). The sources for the identification of zooplankton were Corliss, (1979), Stemberger (1979), Torke, (1974), Thorp and Covich Ed. (1991) and Pennak (1989). 


\section{Field Sampling Quality control}

\section{$\underline{\text { Bottles }}$}

Bottles were placed in a $4 \%$ hydrochloric acid bath for at least 6 hours. After rinsing the bottles with deionized water they were set to dry. Once dried, they were tightly closed until the moment when the samples were collected. The bottles were rinsed with reservoir water at least twice before the water collected with the Van Dorn Bottle or plankton net was added to them. Bottle labels were checked during filling. Sample bottles were placed in a cooler filled with ice for transport to the laboratory. In the laboratory, the samples for nutrient analysis were kept in a freezer until analysis. The other samples were stored in the dark in a refrigerated room at $4^{\circ} \mathrm{C}$.

\section{Labeling}

A set of sampling conventions was developed, and adhered to, during the study period. Labels were made and placed on outside of the bottles used for the sampling.

\section{Field Notes}

Sampling date, time, weather conditions, Secchi disk depth, irradiance data, main station depth, field trip problems and other information were recorded on rainproof paper. The temperature profiles were created using 
these notes to identify the thermocline and the plankton net ranges. The data from these notes were used to create electronic files.

\section{Field Instruments}

All instruments and tools were cleaned before and after each field trip. Batteries were replaced or recharged as needed. Before and after each trip, the $\mathrm{Hydrolab}^{\circledR}$ unit was calibrated against laboratory standards, following the calibration guidelines described in the manual of the unit. The $V \operatorname{lem}^{\circledR}$ units were dried, cleaned; the data was downloaded through the computer interface, and were re-programmed for the next trip.

\section{Replicates and handling of samples}

Replicates samples were taken whenever it was possible $(65.7 \%$ of the time). Of the 38 sampling sets from both Barney Reservoir and Hagg Lake, 25 of these had replicates. Nutrient analysis, chlorophyll-a, ion and alkalinity analysis were performed for all of the replicates. The plankton counts of replicates were as follows: 20 phytoplankton counts were from replicate samples $(65.7 \%)$, and 4 zooplankton counts were from replicate samples (10.5\%). Three of the 38 sampling sets $(7.9 \%)$ were sent to be analyzed for nutrients and ions to the CCA Laboratory, in Corvallis, Oregon. 


\section{Laboratory quality control}

The main procedures followed to ensure accurate results were: a) the systematic cleaning of equipment and glassware and, b) the careful handling and measuring of the different chemical components. The glassware, reusable tips of micropipettes and stirrer bars were acid washed in accordance with the steps described above. The guidelines in the manual of the instruments were heeded and the chemical recipes were strictly followed (Appendix A). All the water samples and replicates were analyzed. 


\section{$\underline{\text { RESULTS }}$}

\section{HAGG LAKE}

In this section the physical, chemical and biological factors that were measured during the sampling period are described and analyzed. Table 8a and $8 \mathrm{~b}$ list a summary of descriptive statistics for Hagg Lake data.

Microphotographs of selected specimens of the plankton are presented in figures $60 \mathrm{a}$ and $60 \mathrm{~b}$.

\section{a) Physical Factors}

\section{Water Inflow and Outflows}

The data on the water inflows and outflows in Hagg Lake came from monthly dam operations reports prepared for the Tualatin Valley Irrigation District (TVID) by the current dam operator, Wally Otto.

In Hagg Lake the inflow and outflow regime during the study period can be described as follows: From June to November, when most of the weather fronts were less severe or moved to higher latitudes, the releases of water were greater than the inflows, and the water level began to drop from $92 \mathrm{~m}$ above mean sea level (a.m.s.l.) to a low of $80 \mathrm{~m}$ a.m.s.l. (Figure 6).

During the month of November the inflows exceeded outflow, and the water levels rose from a low of $80 \mathrm{~m}$ a.m.s.l. to around $86 \mathrm{~m}$ a.m.s.l. From 
the end of November 1998 through April 1999 the water levels fluctuated, with water outflows balancing or slightly less than water inflows, and the water levels reaching $93 \mathrm{~m}$ a.m.s.l. During the month of May the reservoir water levels reached a stable elevation of $92 \mathrm{~m}$ a.m.s.l. and then the cycle began again (Figure 7).

Hagg Lake (S.R.) Water Elevation and Precipitation

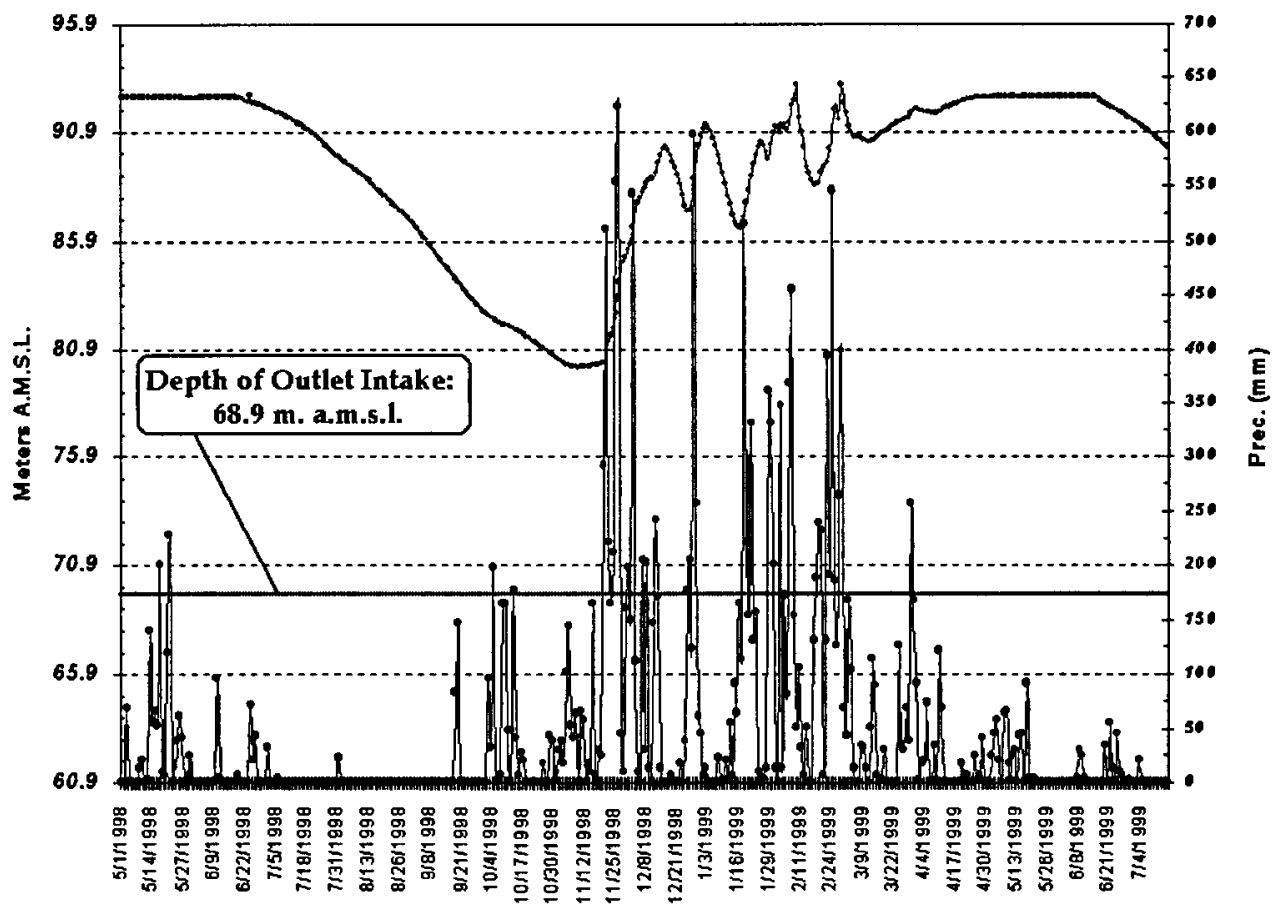

Figure 6. Hagg Lake. Water elevation and precipitation (data from TVID, 1999). 


\section{Hagg Lake (S.R.) Water \\ Inputs vs. Outputs}

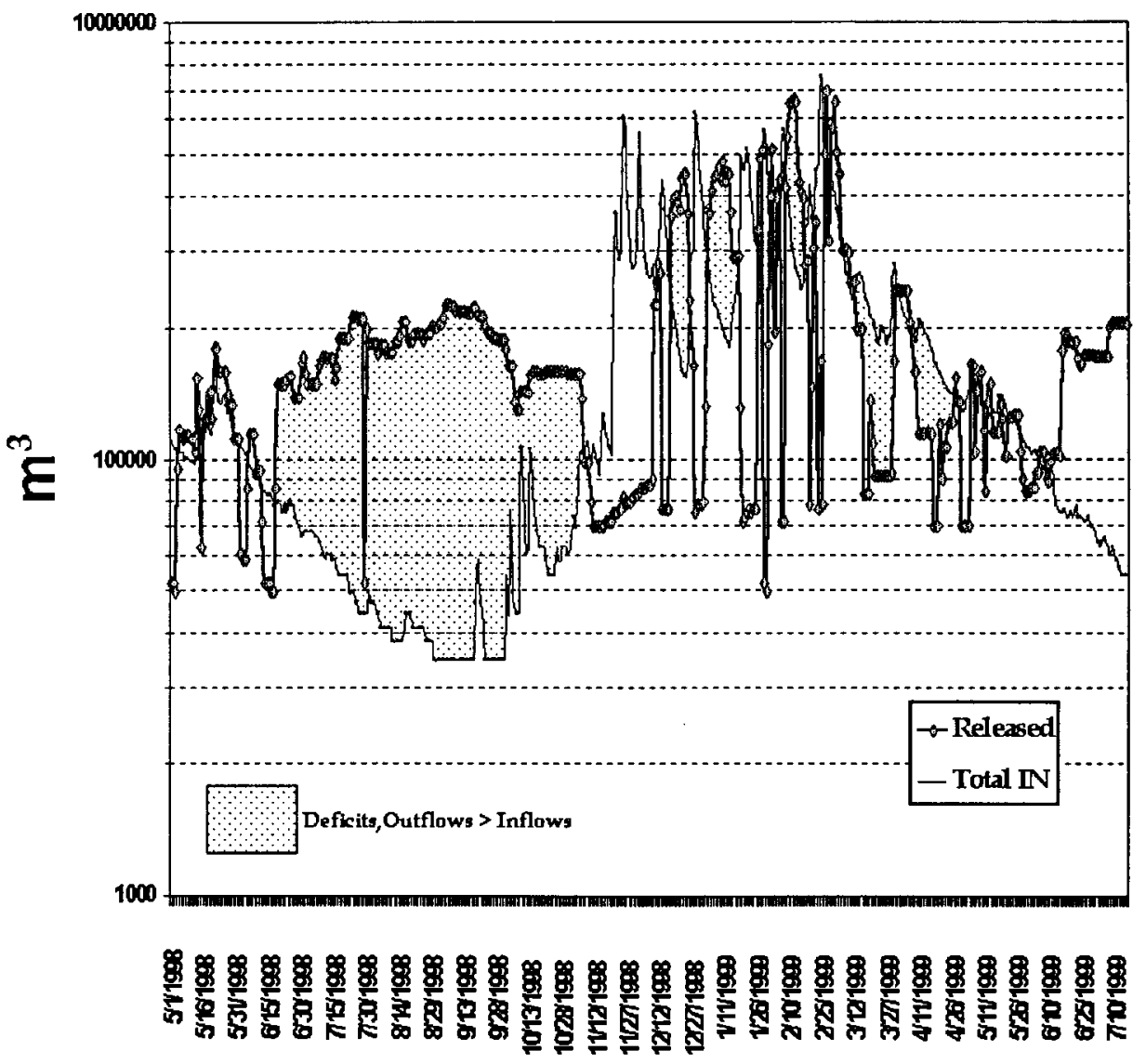

Figure 7. Water inflows and outflows in Hagg Lake (data from TVID, 1999). 
From June to October 1998, the hydraulic mean residence time was less than 2.5 years (Figure 8 ). Afterwards, it fluctuated with the increases in inflows and the subsequent high releases, reaching high hydraulic mean residence times of upwards of 22 years and a low hydraulic mean residence time of 40 days.

Hagg Lake (S.R.) Hydraulic Resident Time (Years)

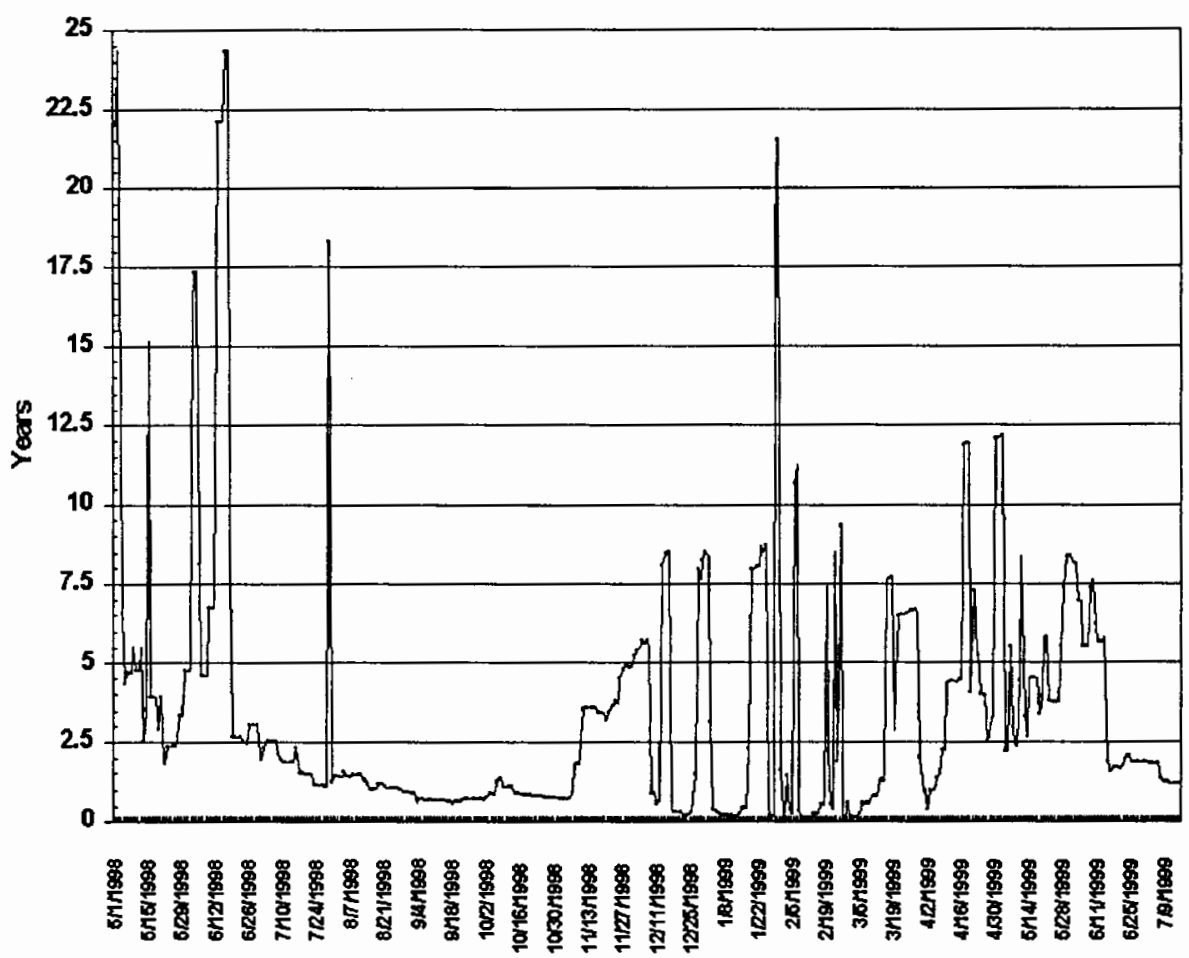

Figure 8. Hagg Lake. Hydraulic Mean Residence Time (Years). 
For most of the sampling period, the water releases in Hagg Lake were from the upper hypolimnion; as the water levels dropped below $85 \mathrm{~m}$ a.m.s.l. (Figure 6) the water was withdrawn is from the lower metalimnion. The temperature of the water released was cold during the winter $\left(5.7^{\circ} \mathrm{C}\right)$ and cool during summer $\left(9\right.$ to $\left.13^{\circ} \mathrm{C}\right)$. At its lowest water levels (OctoberNovember 1998), the water released came from the upper metalimnion (Figure 9).

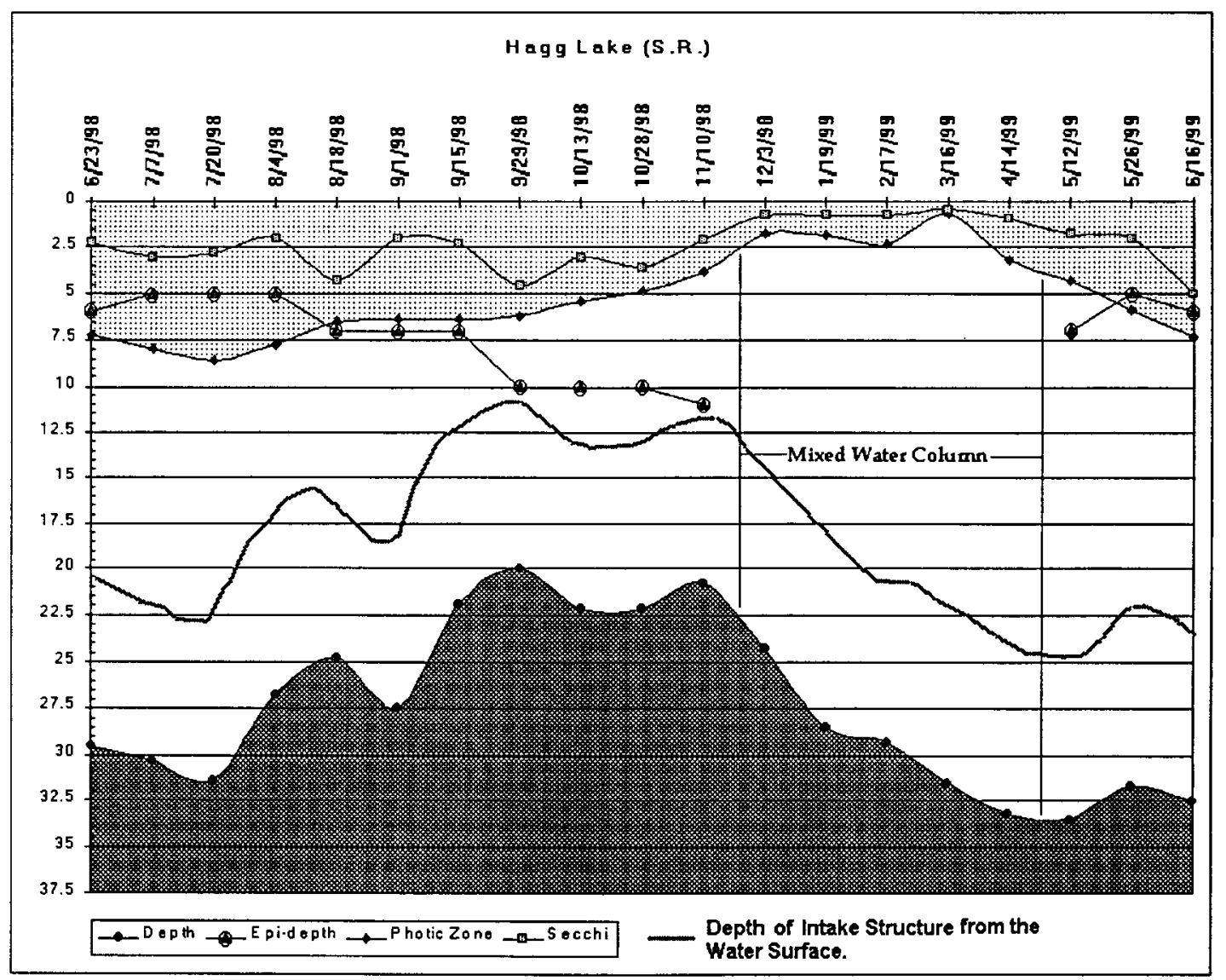

Figure 9. Hagg Lake. Water, Epilimnion, Secchi and Photic Zone Depths. 


\section{Temperature}

Hagg Lake had a strong temperature stratification that began in May and lasted through the middle of November. From the end of November to early May Hagg Lake was under constant mixing due to strong winds associated with synoptic cycles or cold fronts, and due to increased inflows of Scoggins, Sain and Tanner Creeks.

The epilimnetic temperature had a high of $25.2^{\circ} \mathrm{C}$ in August 1998 and a low of $5.8^{\circ} \mathrm{C}$ in February 1999. The temperature graph had a sinusoidal shape with a maxima and minima occurring at around two months after the longest and shortest days of the year (Figure 10).

The seasonal temperature isotherms (Time-depth) graph shows the extent of the stratification and its depths. The influence of the changing depth levels is reflected in the relatively cool hypolimnion, which changed from $7^{\circ} \mathrm{C}$ in June 1998 to $8.6^{\circ} \mathrm{C}$ in October 1998. The depth of the epilimnetic layer increased as the water level dropped, and as more water from the metalimnion was released through the intake structure (Figure 11). 


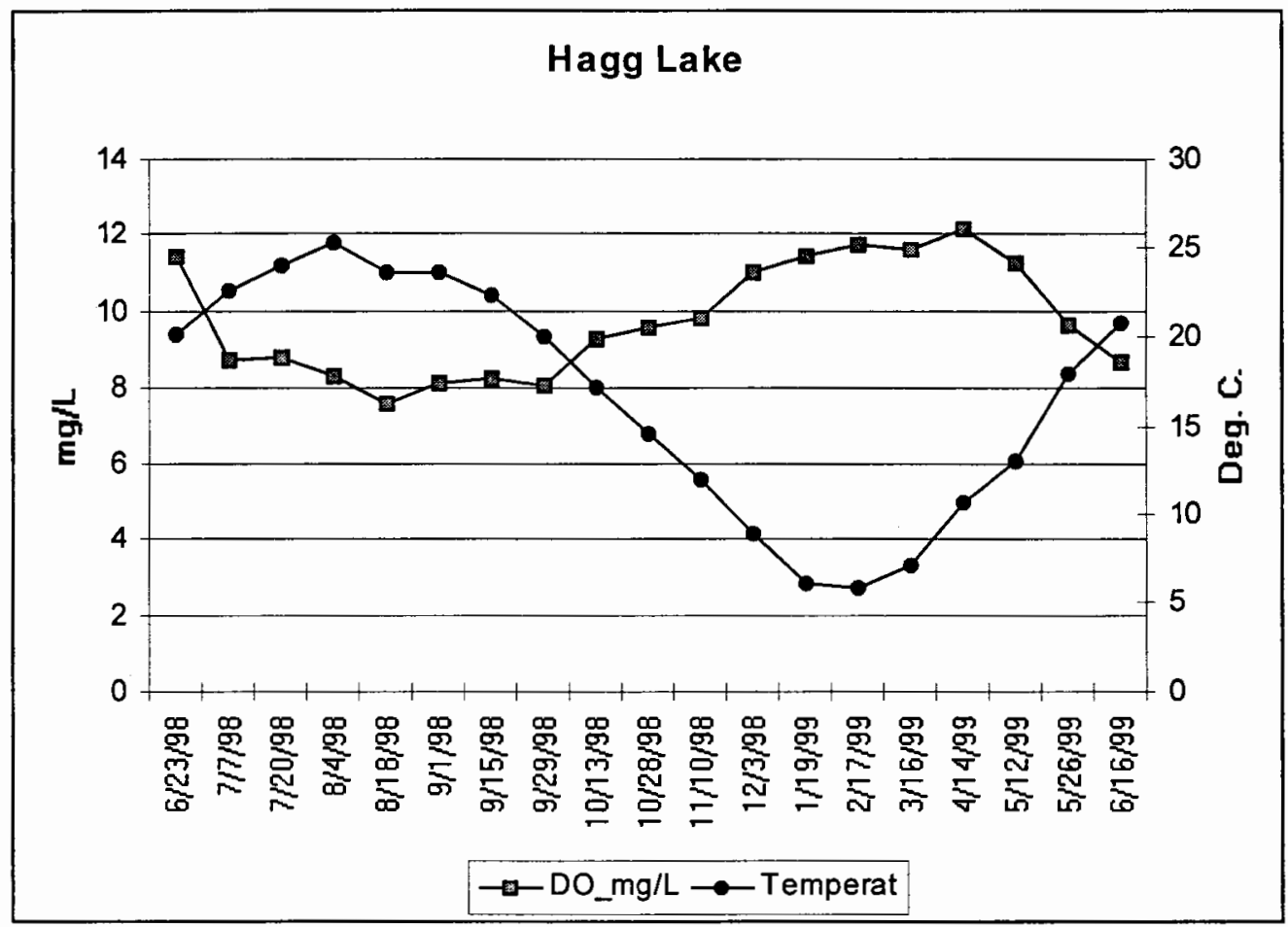

Figure 10. Hagg Lake. Epilimnetic DO, Temperature and Chlorophyll-a.

After the water stratified, the most noticeable changes in the temperature profiles were in the epilimnion. Changes in the depth of the intake structure in relation to the surface of the water, produced an epilimnion with a constant temperature, a short and steep metalimnion and a gradual decline in temperature to the bottom of the lake in the hypolimnion (Figure 12). 


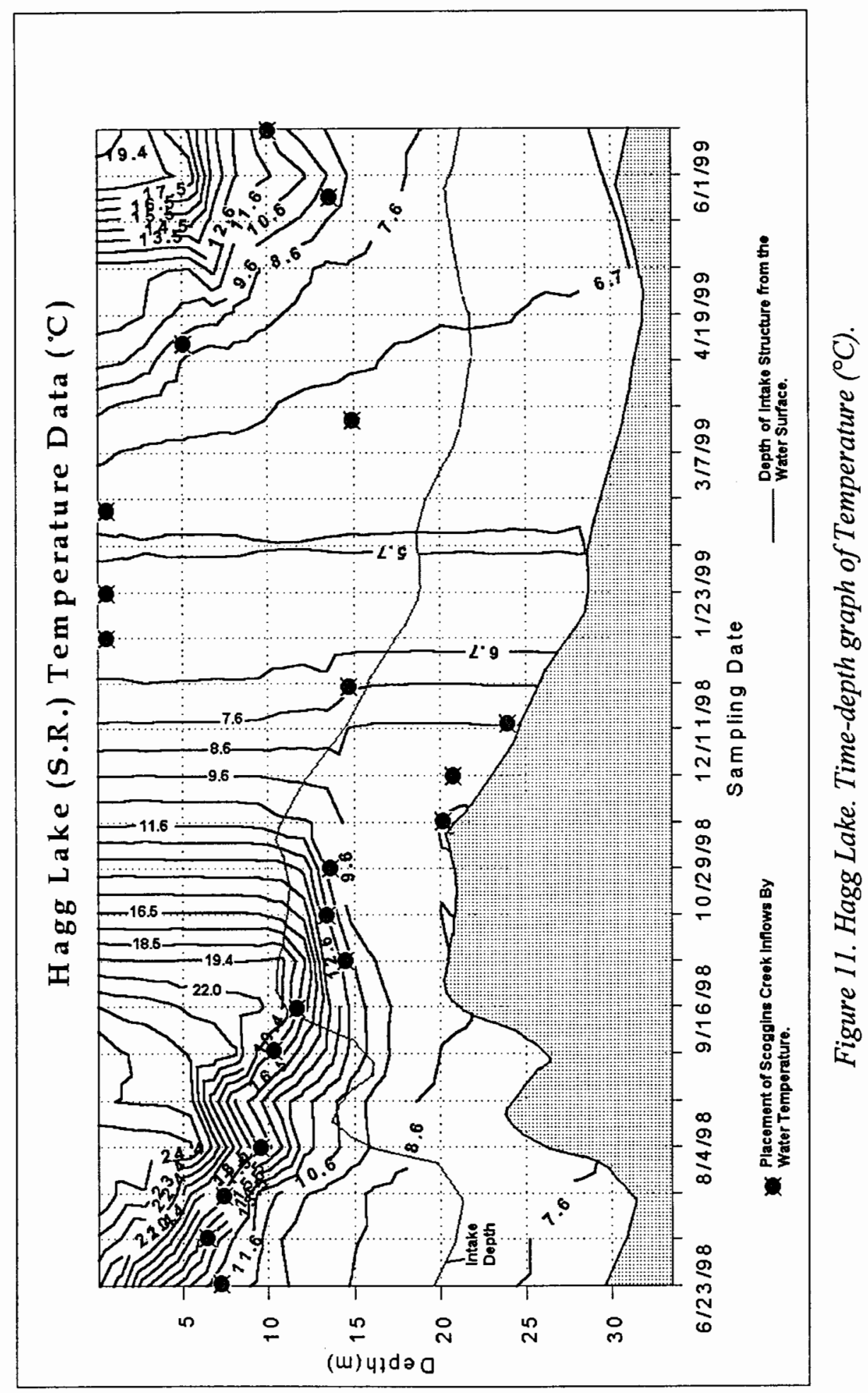




\section{Hagg Lake Temperature Profiles}

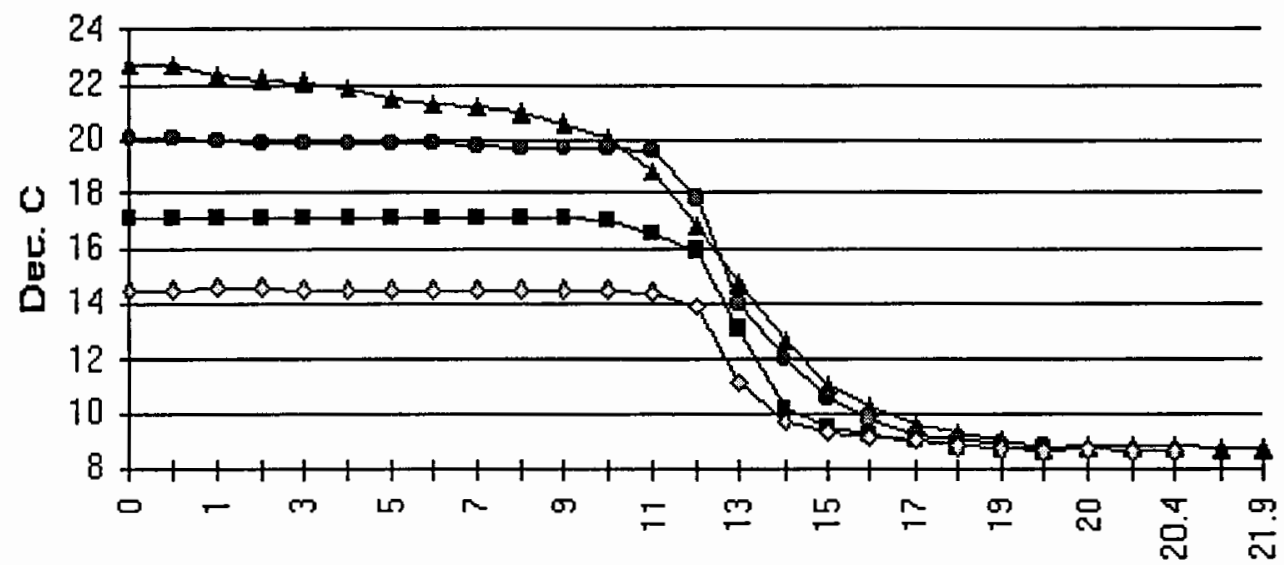

Depth (m)

$$
\rightarrow-9 / 15 / 1998 \rightarrow-9 / 29 / 1998 \rightarrow 10 / 13 / 1998 \multimap-10 / 28 / 1998
$$

Figure 12. Hagg Lake. Temperature profiles from 9/15/1998 to 10/28/1998.

The temperature of the outflows from Hagg Lake corresponded to the temperature measured at the depth of the intake structure. Inflows from Scoggins Creek were located, according to their temperature in the seasonal temperature isotherms (Figure 11). 


\section{Dissolved Oxygen}

The epilimnetic layer was oxygenated throughout the year, with a low concentration of $7.5 \mathrm{mg} / \mathrm{L}$ in August and a high concentration of $12.2 \mathrm{mg} / \mathrm{L}$ in April 1999. The highest levels of dissolved oxygen occurred from November 1998 to May 1999. The peak levels of dissolved oxygen coincided with the peak values in chlorophyll-a indicating the strong influence of the photosynthetic activity of the phytoplankton.

The effects that the changes in depth of intake structure depth relative to the water surface had on dissolved oxygen was as follows: with water withdrawn from higher and higher layers of water, a pocket of anoxic water appeared near the bottom of the lake. From 8/18/1998 to 10/28/1998, the water levels were at their lowest and a layer of anoxic water $4.5 \mathrm{~m}$ thick was measured on October 13, 1998.

These low water levels isolated the hypolimnion from withdrawals of the intake structure contributing to the formation of a clinograde curve of D.O. with low values measured at the depth of the intake structure that decrease further as they are measured near the bottom of the reservoir, until reaching the anoxic layer (Figure 13a and 13b). In figure 11, the placement according to their temperature of the waters entering the reservoir through Scoggins Creek is portrayed. Their dissolved oxygen contribution appeared limited to the depths at which they were placed. 


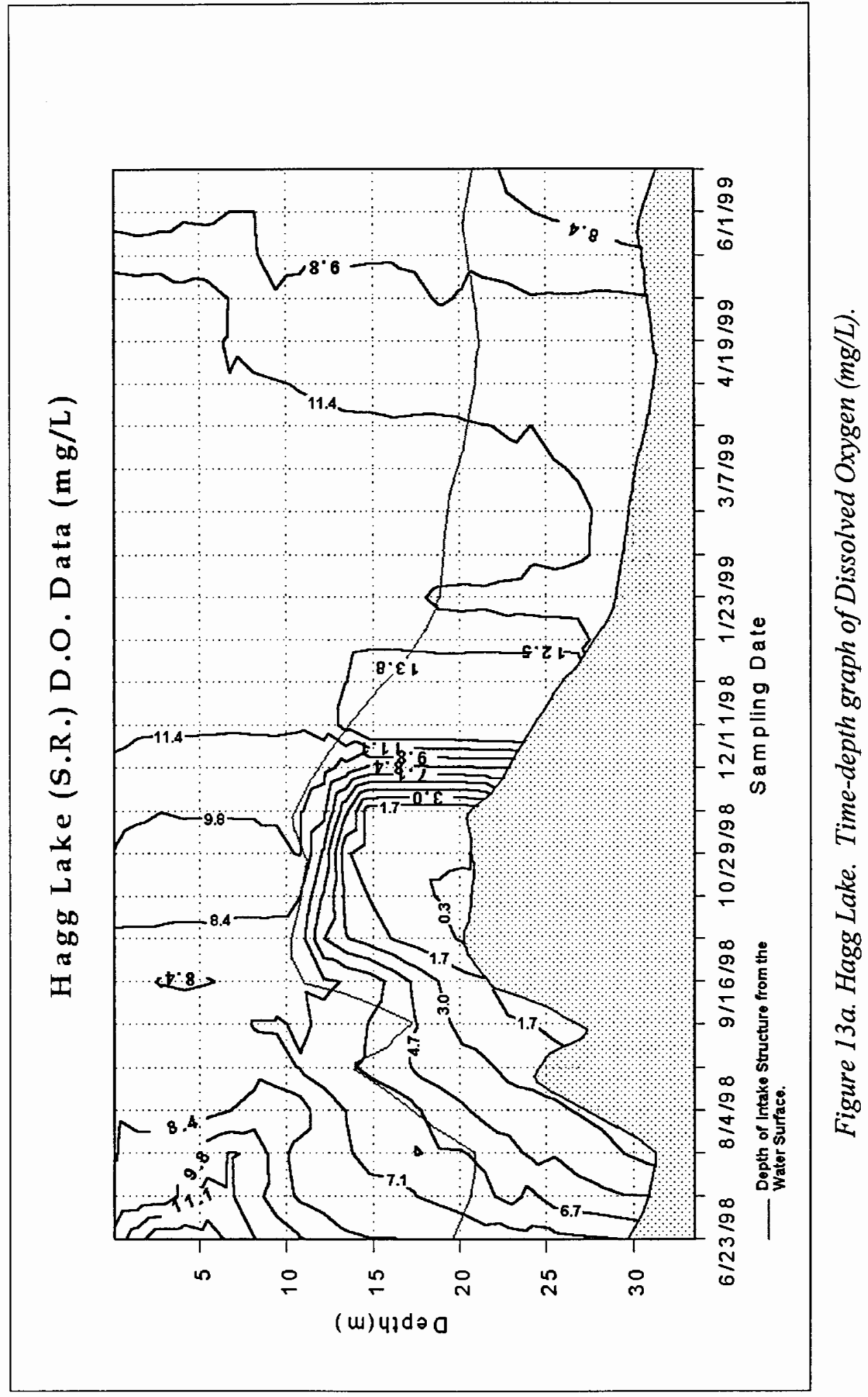




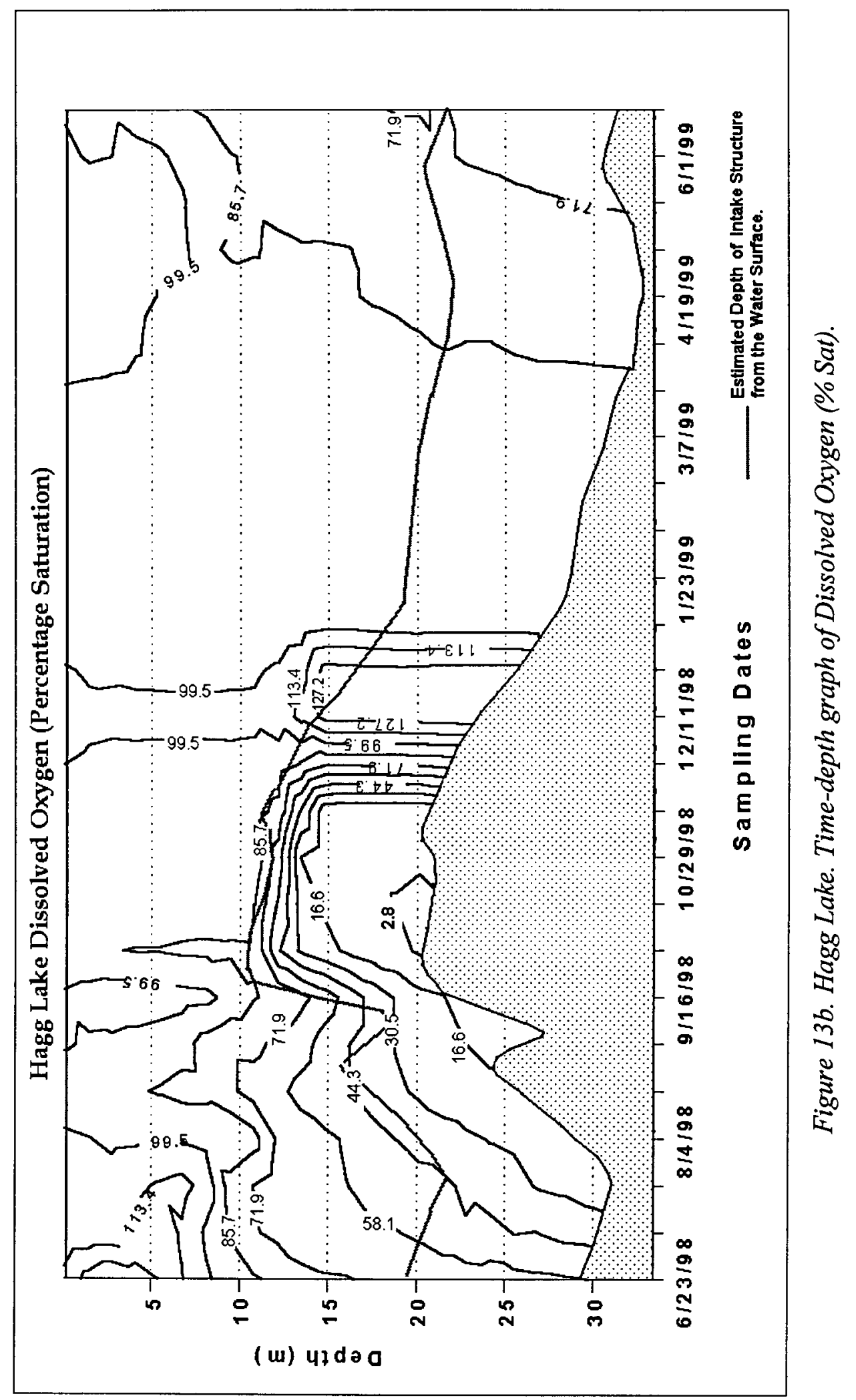




\section{Secchi depth and Irradiance}

In Hagg Lake the Secchi depth was greater from June to the end of October 1998. The highest Secchi depth was measured on August 18, (4.3 m) and September 29, 1998. The average Secchi depth form June to October 28, 1998 was $2.9 \mathrm{~m}$. The Secchi depth decreased with the beginning of the winter storms and had a low of $0.4 \mathrm{~m}$ in March 1999 (Figure 14).

\section{Hagg Lake}

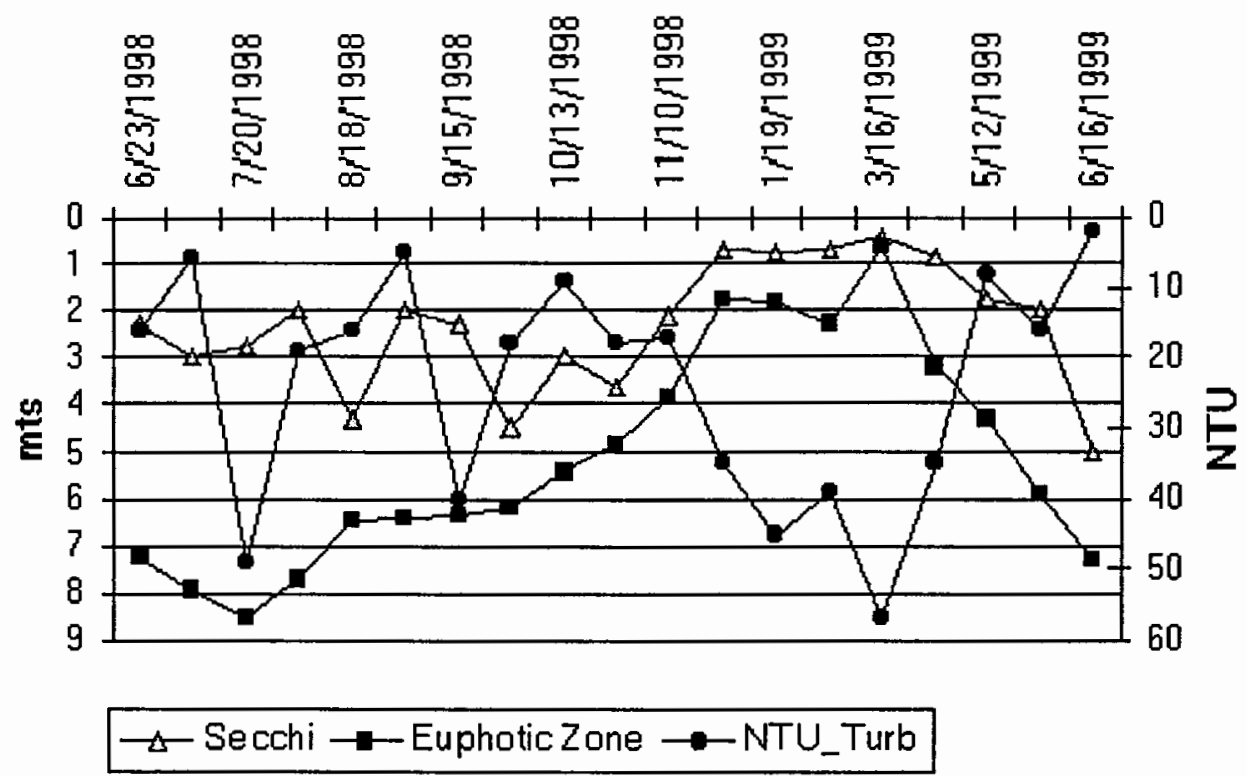

Figure 14. Hagg Lake. Secchi and Photic depth. 
The measurements of irradiance $\left(\mu\right.$ Einsteins $\left.\mathrm{m}^{-2} \cdot \mathrm{s}^{-1}\right)$ were used to calculate the depth of the photic zone or the depth where irradiance levels are $1 \%$ surface irradiance (Wetzel, 1991). The pattern that emerged was somewhat similar to the Secchi depth, except that what could be termed biological clear-water phase coincided with the time when lowest photic zone and lowest chlorophyll-a were measured (July 20, 1998, Figure 20 and Figure 9).

The photic zone was generally deeper from the end of spring 1998 to the end of the fall 1998; the deepest photic zone was measured at $8.56 \mathrm{~m}$ on July 20,1999. The depth of the photic zone decreased as the concentration of particles in the water increased, and a low of $0.6 \mathrm{~m}$ was measured in March $16,1999$.

\section{Turbidity}

The measurements of turbidity changed through the sampling period according to the loads of materials entering from the creeks that feed Hagg Lake (Figure 15). The epilimnetic turbidity was negatively correlated with the photic zone depths. Turbidity in the water column seemed affected by an observed mid-summer input of sediments that entered the reservoir from the Sain Creek, probably caused by increased human activities in its watershed 
(logging or road construction). These mid-summer events occurred July 20 and September 19, 1998, and in these occasions the maximum turbidity readings in the water column were 141 and 195 NTU respectively. Some rain events, road construction or clear-cutting occurred around these dates. From these events it was evident that small human impacts on the watershed during the dry season had a greater impact on turbidity than during the rainy season when sediments and other materials entering the reservoir are diluted in large volumes of water. 


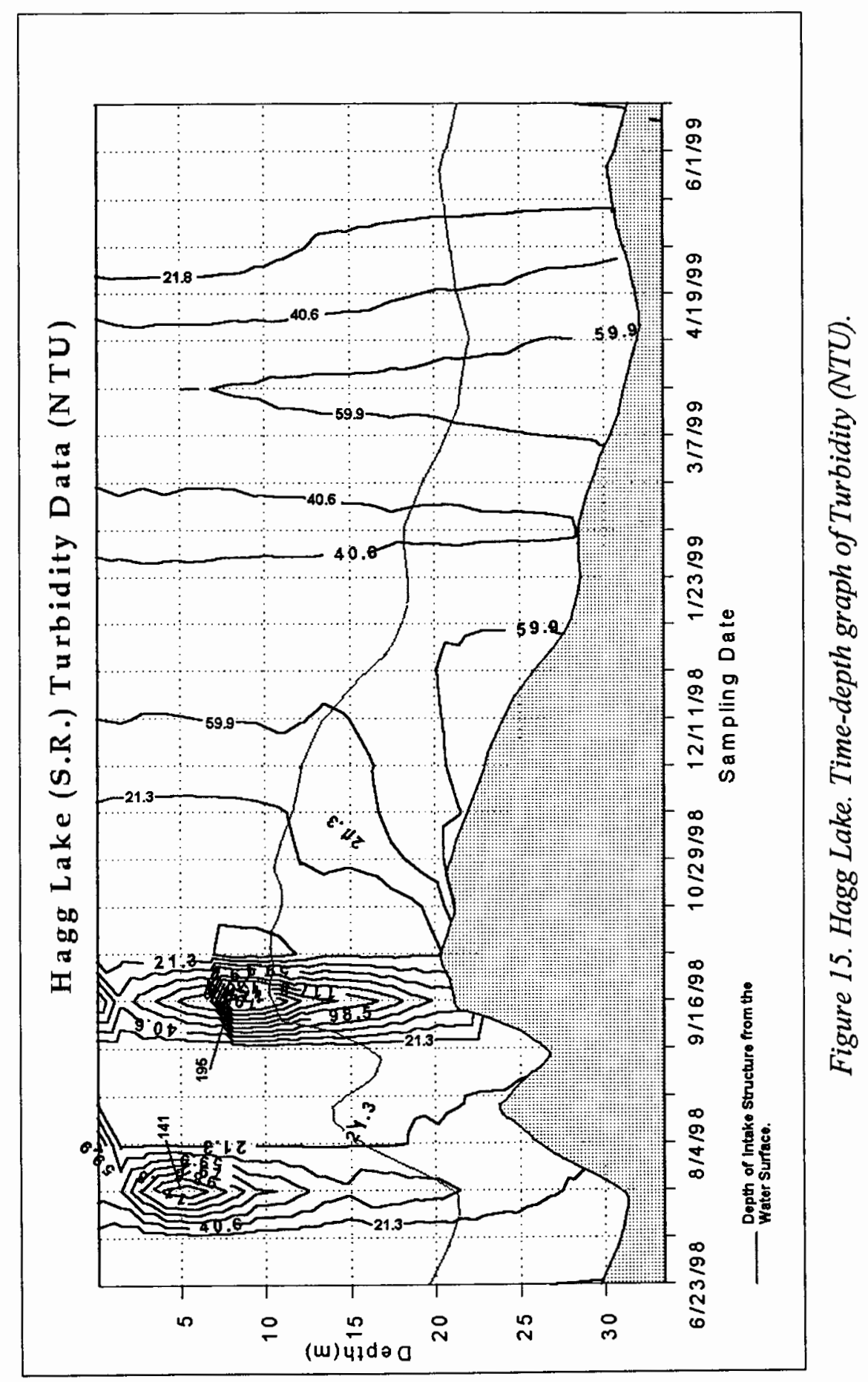




\section{b) Chemical factors}

\section{1. $\underline{p H}$}

Epilimnetic $\mathrm{pH}$ increased during the late spring and summer of 1998, and during the peak of the photosynthetic activity in May 1999, reaching a value of 8.6 units, then diminished gradually to a value of 6.9 units. From November 1998 through March 1999 the $\mathrm{pH}$ value was between 6.7 and 6.9. In the anoxic zone of hypolimnion (Summer 1998) the $\mathrm{pH}$ readings were between 6.4 and 6.6 units (Figure 16). The time-depth graph had a similar structure to the temperature with relatively high $\mathrm{pH}$ values in the epilimnion, and low in $\mathrm{pH}$ values in the metalimnion - hypolimnion during the late spring, summer and early fall. A decrease in $\mathrm{pH}$ occurred with increasing inflows and mixing of the water column. 


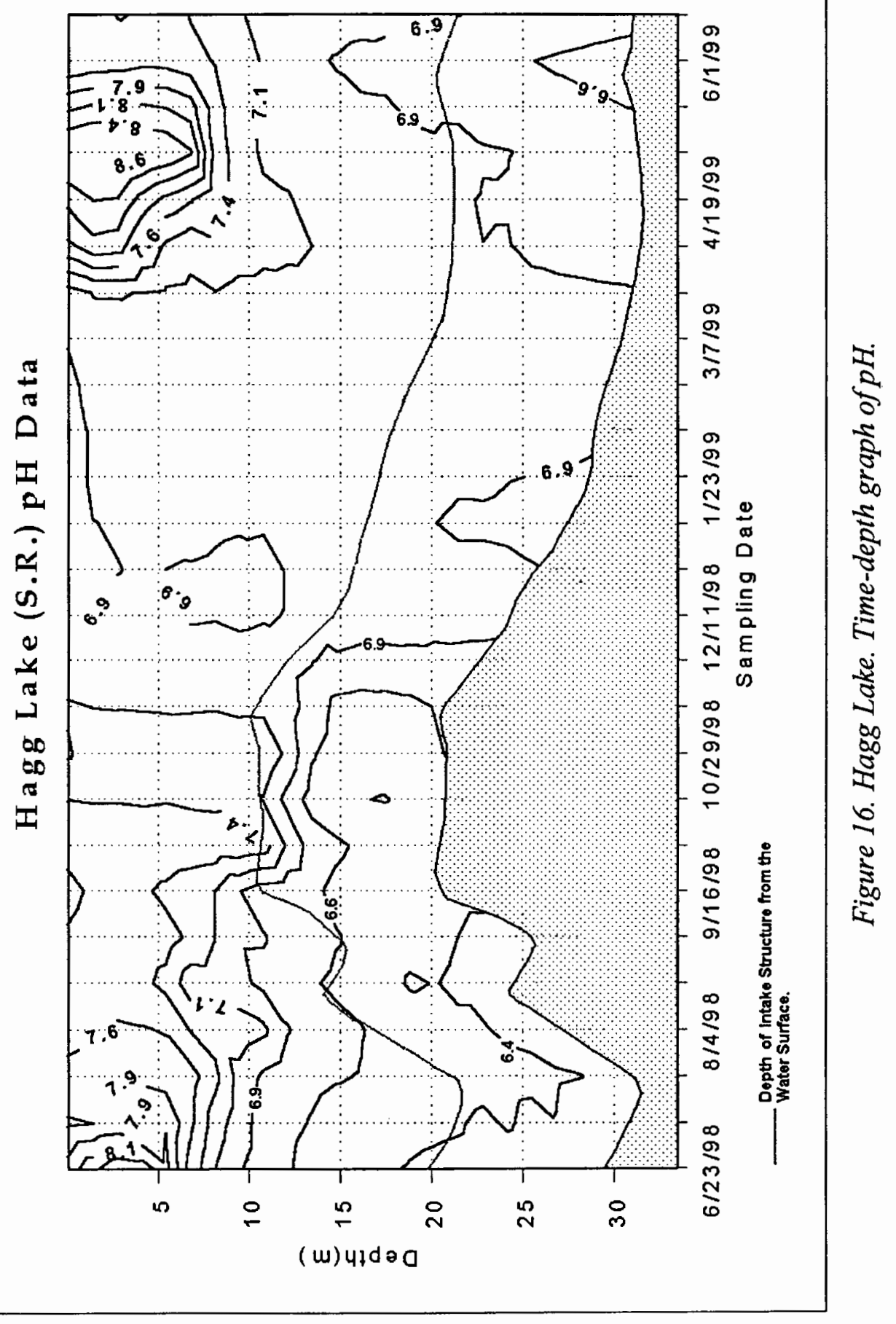




\section{Conductivity and Redox}

From December 1998 to June 1999, the epilimnetic conductivity fluctuated between 54 and $42 \mu \mathrm{S} / \mathrm{cm}$. In the summer and fall of 1998 the epilimnetic conductivity increased to up to $70.5 \mu \mathrm{S} / \mathrm{cm}$ in October. With low dissolved oxygen and $\mathrm{pH}$ values the conductivity increased. Whenever the elevation of the water was less than $92 \mathrm{~m}$ a. m. s. 1 . (31 $\mathrm{m}$ of water depth) a slight decrease in conductivity at the depth of intake structure was observed. The July 1998 sample had a change in conductivity at the depth of the intake structure of 60 to $54 \mu \mathrm{S} / \mathrm{cm}$; in October, the change was from 70 to $60 \mu \mathrm{S} / \mathrm{cm}$ (Figure 17b). These slight changes could be explained by water in the reservoir being displaced by the water from the creeks that feed and enter the riverine zone as underflows or overflows (Figure 17a). 


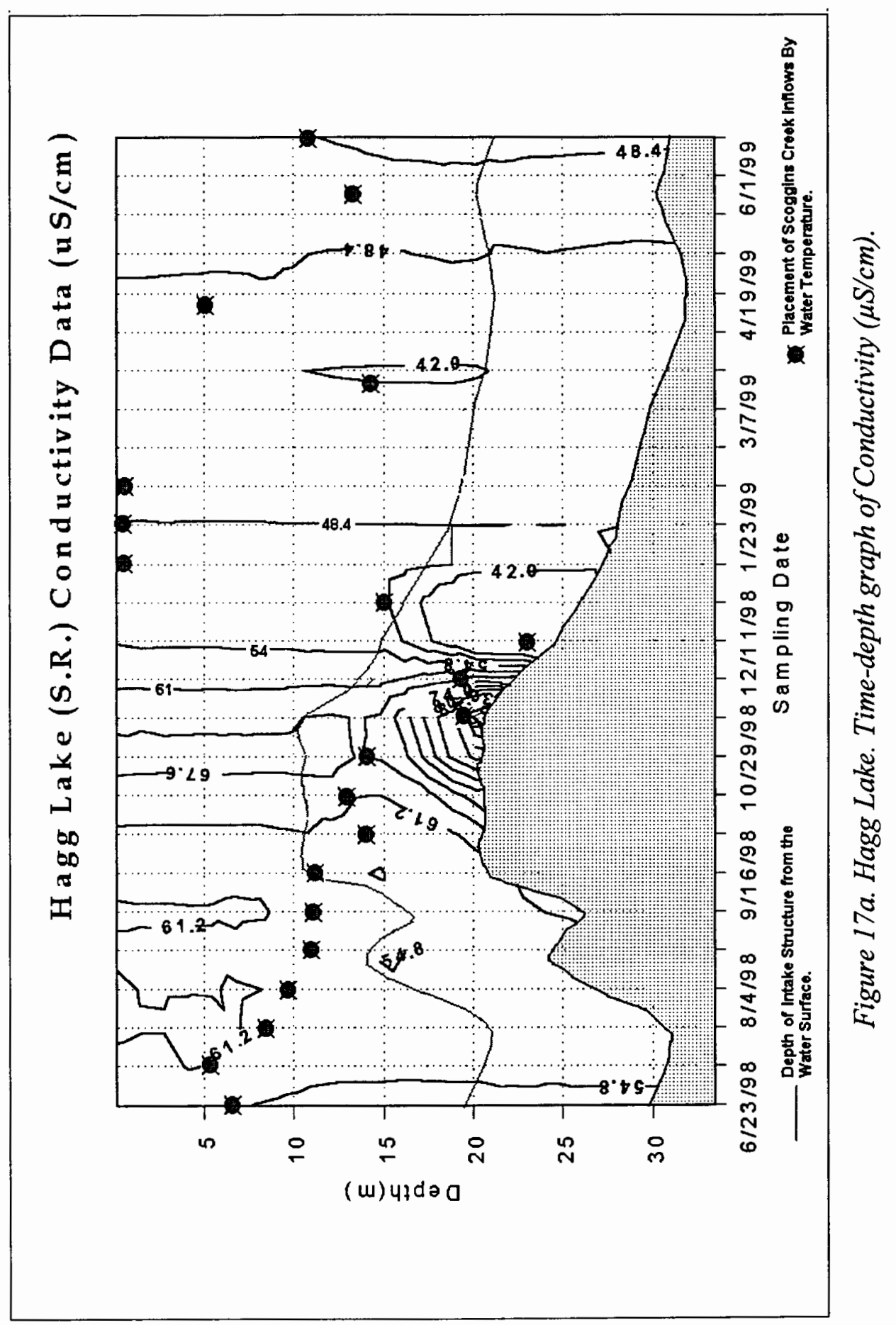




\section{Hagg Lake Conductivity}

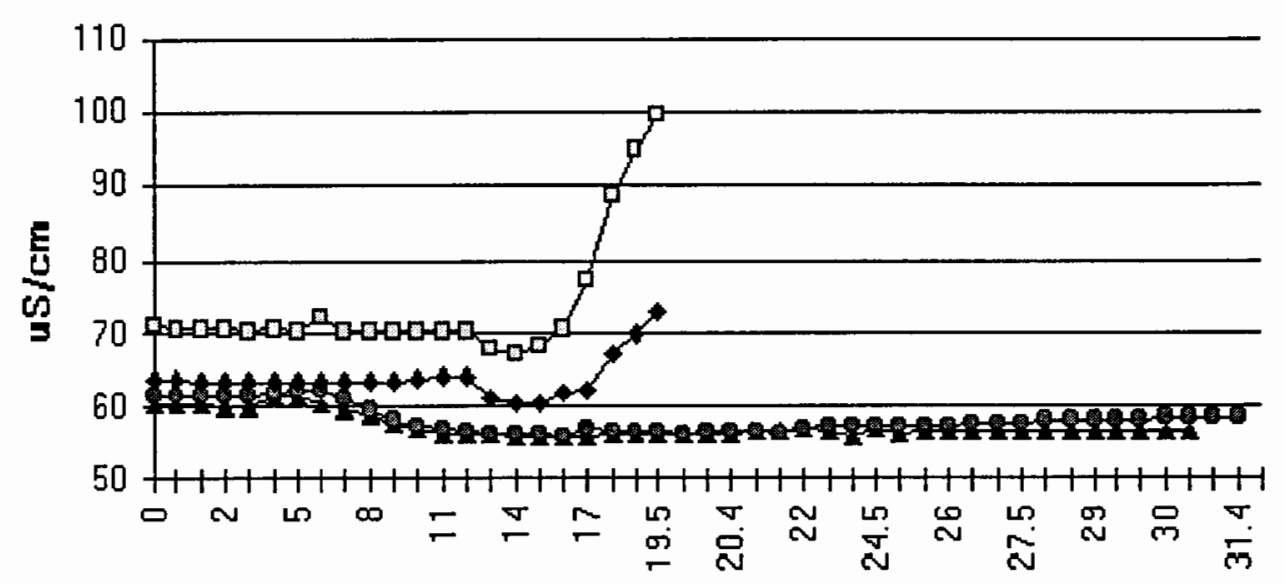

Depth (m)

$\rightarrow-7 / 7 / 1998 \rightarrow-7 / 20 / 1998 \rightarrow-10 / 13 / 1998 \rightarrow-10 / 28 / 1998$

Figure 17b. Hagg Lake. Conductivity profiles from July and October 1998.

The time-depth graph of redox potential had similar structure to the time-depth graph of the conductivity, with low redox values in the epilimnion during the summer of 1998 , higher values in the metalimnion and during the winter months. The main summer feature was a low redox potential of $217 \mathrm{mV}$, as anoxia formed in the lower hypolimnion layer during the summer (Figure 18). As stated by Reynolds (1984) and Sommer (1989), low redox values and low $\mathrm{pH}$ create conditions where nitrate is reduced to 
ammonia, and other nutrients are released from the sediments into the waters. These nutrients can reach the epilimnion and cause blooms of algae that might interfere with the water treatment and human consumption of these waters. In Hagg Lake an increase in hypolimnetic ammonium was observed during the period of anoxia and low redox potential. 


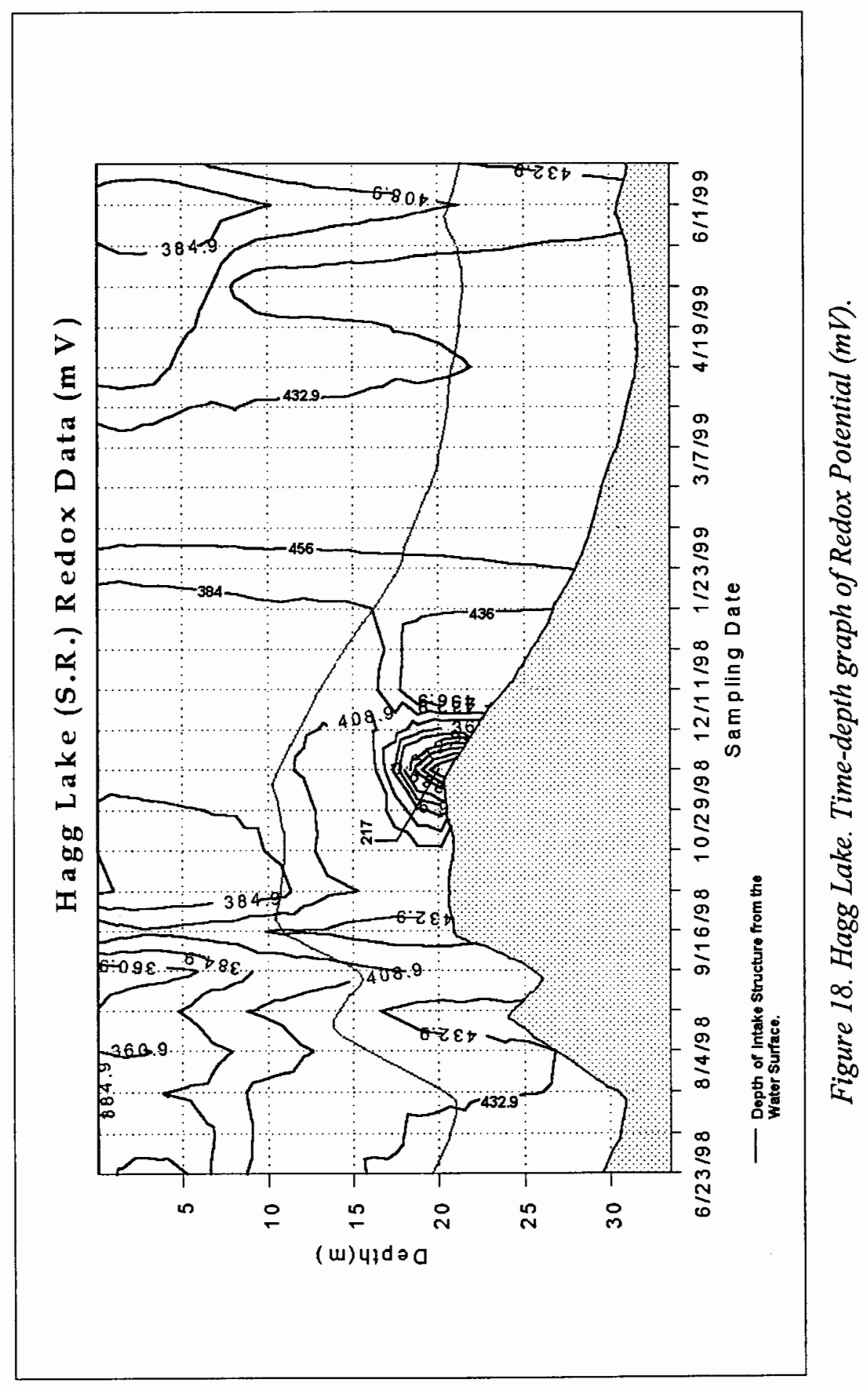




\section{Alkalinity and Dissolved Inorganic Carbon (DIC)}

Alkalinity (Acid Neutralizing Capacity) was measured in $\mu$ Equivalent/L units. Average epilimnetic alkalinity from June to October 1998 was calculated at $582 \mu \mathrm{Eq} / \mathrm{L}$. From October 1998 to June 1999 the average was $533 \mu \mathrm{Eq} / \mathrm{L}$. The highest alkalinity was measured in August 1998. This increase was concurrent with an increase in conductivity (Figure 19a). From June to July 1998 and April to June 1999, measured epilimnetic and hypolimnetic alkalinity were similar. The summer 1998 and winter 1999 measured epilimnetic and hypolimnetic alkalinity were different, and these differences appeared related to changes in water levels and inflows.

The summer 1998 distribution of DIC in the water column seemed affected by biological reactions (Wetzel 1983). The dissolved inorganic carbon (DIC) was derived from $\mathrm{pH}$ and alkalinity measurements (Wetzel and Likens, 1991). The trends of DIC followed the trends of alkalinity, and had a calculated high concentration of $0.22 \mathrm{mg} \mathrm{C} / \mathrm{L}$ in August 1998. Other high values were measured in October 1998 and February 1999. DIC was higher in the metalimnion and hypolimnion, except during late Fall 1998 and winter 1999 when it was either equal or lower than the calculated epilimnetic DIC (Figure 19b). 


\section{Hagg L. Alkalinity}

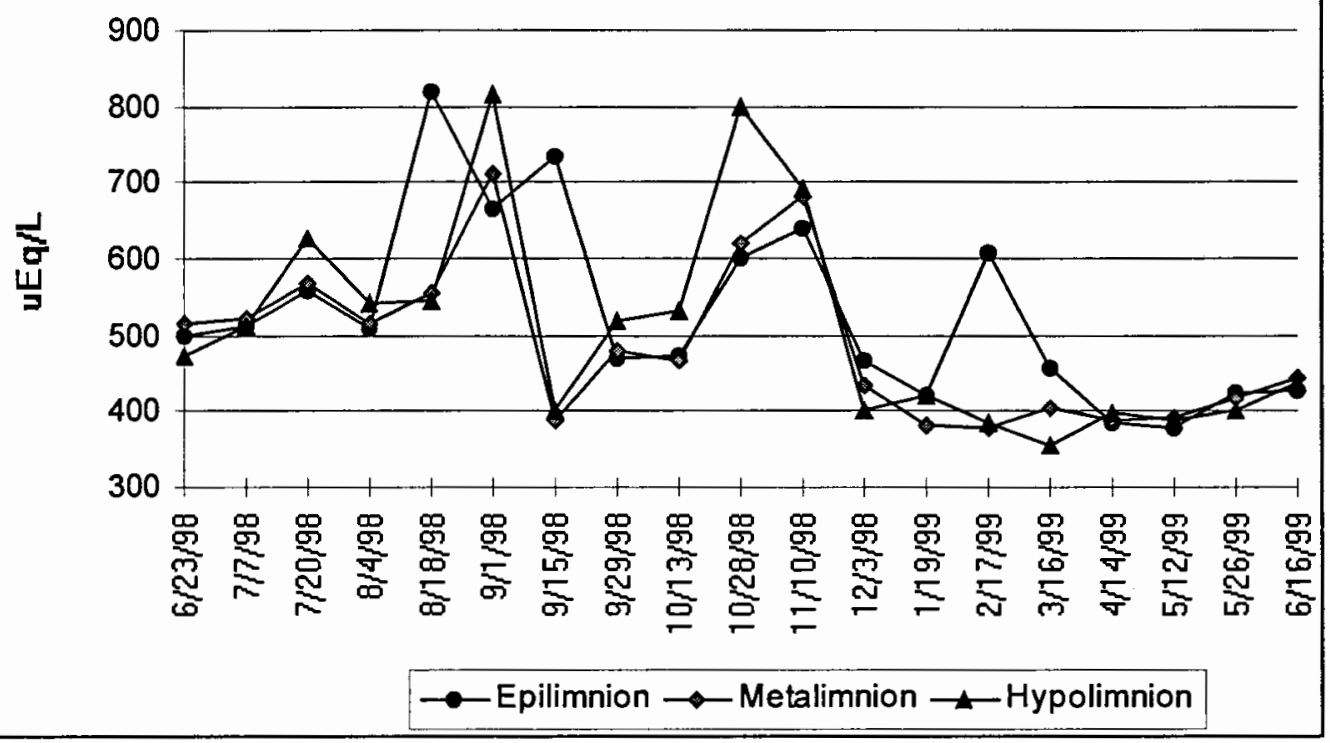

Figure 19a. Hagg Lake. Alkalinity $(\mu E q / L)$.

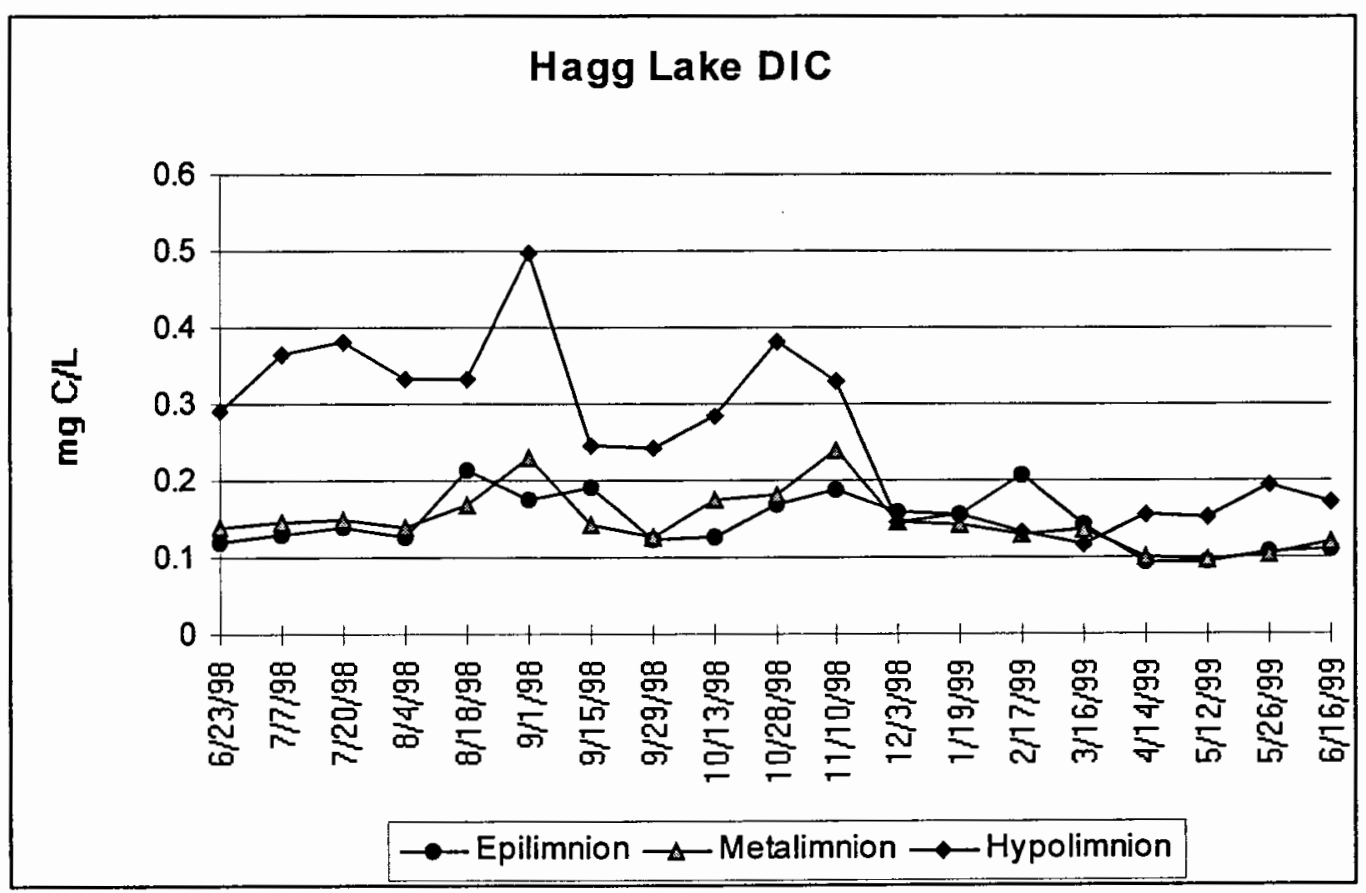

Figure 19b. Hagg Lake. Dissolved Inorganic Carbon (mg C/L). 


\section{Chlorophyll-a}

In June 1998 a bloom of Synedra radians caused an epilimnetic chlorophyll-a measurement of $14.76 \mu \mathrm{g} / \mathrm{L}$. From July to October, epilimnetic chlorophyll-a values were lower than $4 \mu \mathrm{g} / \mathrm{L}$. In November 10, 1998 chlorophyll-a concentration was measured at $6.67 \mu \mathrm{g} / \mathrm{L}$ coinciding with an increase in biovolume of Cryptomonas sp. In February 1999, epilimnetic chlorophyll-a was measured at $0.19 \mu \mathrm{g} / \mathrm{L}$. The samples of April and May 1999 had concentrations of 13.1 and $12.8 \mu \mathrm{g} / \mathrm{L}$ respectively at the same time as biovolumes of Chlamydomonas sp. and Fragilaria crotonensis increased. Chlorophyll-a decreased to lower values in early June 1999 when the sampling period ended (Figure 20).

Metalimnion measurements of chlorophyll-a were consistently lower than epilimnetic chlorophyll-a, except during a period spanning the middle of July to the beginning of September when sunny days prevailed. This extra irradiance, low nitrogen concentrations, and high temperatures might have interfered with photosynthesis efficiency of the species present in the epilimnion. Hypolimnion chlorophyll-a concentration were always lower than metalimnetic and epilimnetic measurements. 


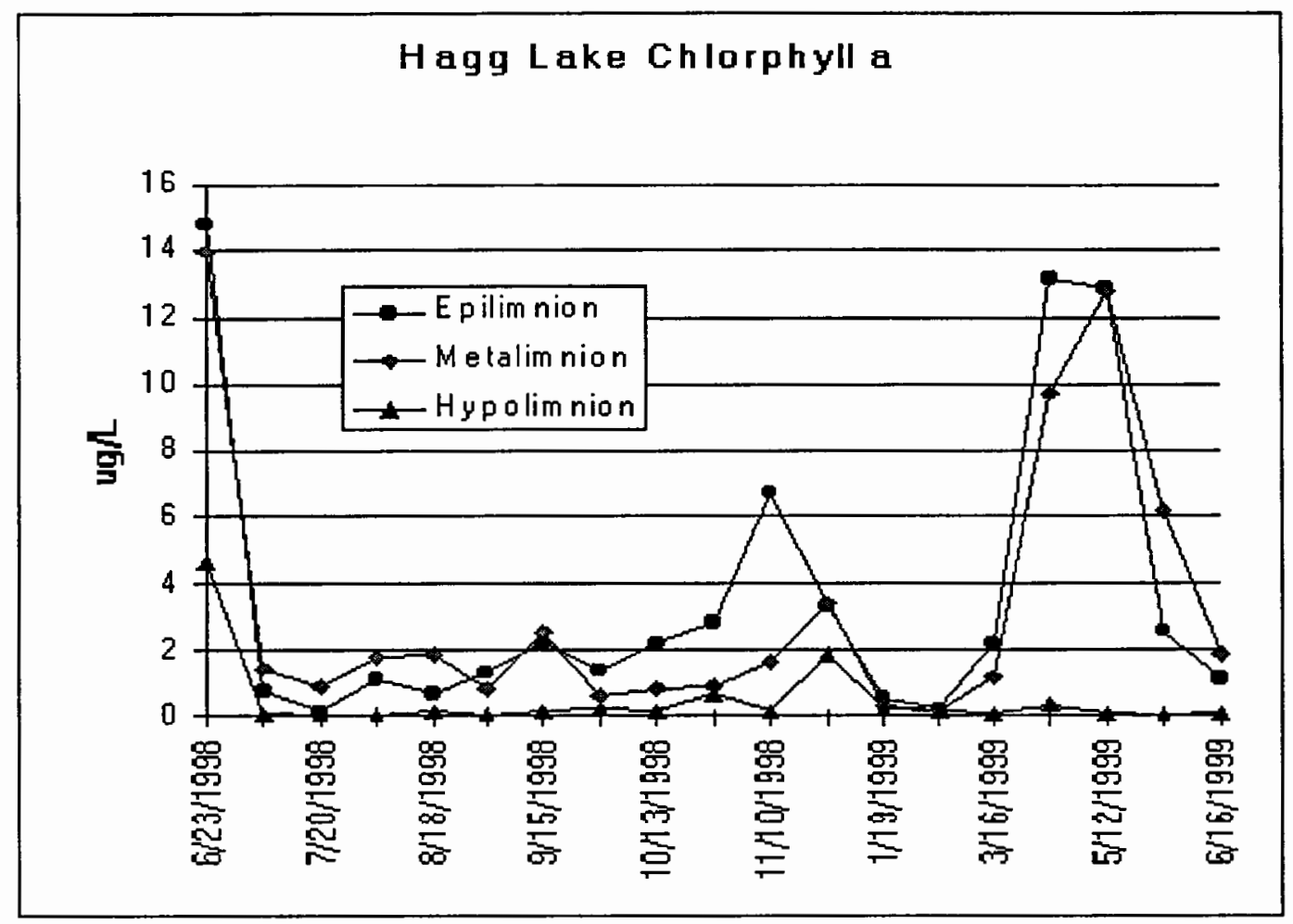

Figure 20. Hagg Lake. Chlorophyll-a $(\mu g / l)$.

\section{Total Nitrogen, Nitrate + Nitrite and Ammonia Nitrogen}

From June to October 1998 the epilimnetic concentration of total nitrogen had a value of less than $200 \mu \mathrm{g} / \mathrm{L}$. With higher inflows during October 1998 to April 1999 the concentration of total nitrogen increased, having a peak value of $671 \mu \mathrm{g} / \mathrm{L}$ in March 1999 (Figure 21). Spring and summer metalimnetic total nitrogen concentrations were similar to epilimnetic total nitrogen, except on July 7,1998 and October 131998 when 
the concentrations were much higher. On these occasions rain events had occurred in the previous week, and underflow waters could have carried a delayed nutrient pulse. From October 1998 to April 1999 epilimnetic total nitrogen increased with a high measurement of $671 \mu \mathrm{g} / \mathrm{L}$.

Summer hypolimnetic total nitrogen was always greater than the epilimnetic measurements. From October 1998 to April 1999 hypolimnetic concentrations of total nitrogen were similar to epilimnetic and metalimnetic concentrations, but from May to June 1999, the total nitrogen concentration in the hypolimnion remained high while epilimnetic and metalimnetic total nitrogen decreased. The explanation offered at this time by the author is that wind induced mixing and high water inflows homogenized the distribution of total nitrogen in the water column. 


\section{Hagg Lake Nitrogen sp.}

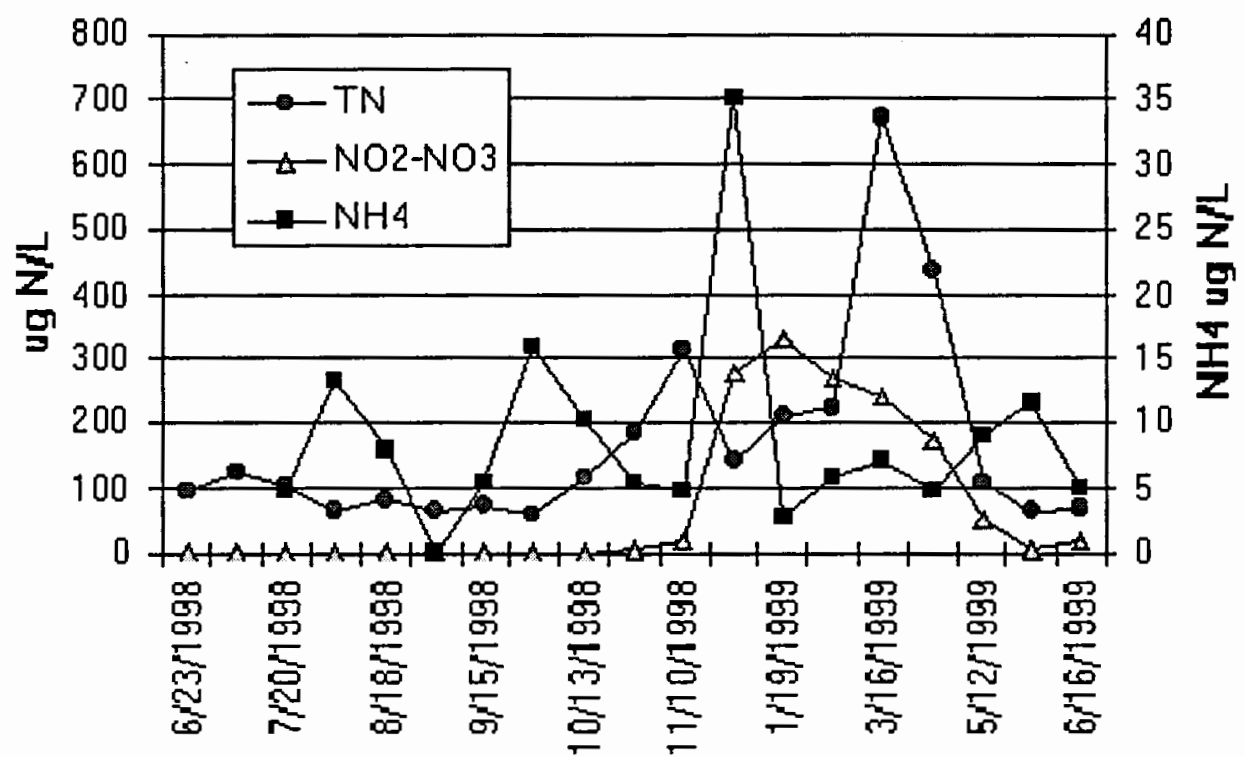

Figure 21. Hagg Lake. Epilimnetic Nitrogen species in $\mu \mathrm{g} / \mathrm{L}$.

From June to November 1998, the nitrate+nitrite epilimnetic concentrations were lower than $16 \mu \mathrm{g} / \mathrm{L}$. Loads from the water inflows raised nitrate+nitrite concentrations in the water column and its peak concentration was measured at $330 \mu \mathrm{g} / \mathrm{L}$ in January 1999; by May 1999 the nitrate+nitrite concentrations had decreased to the spring 1998 lows. The hypolimnetic concentrations of nitrate+nitrite during the spring, summer and early fall 1998, and the early spring 1999 were greater than $100 \mu \mathrm{g} / \mathrm{L}$. However, a low concentration was observed in November 1998. At this time, 
low redox potential and low D.O. was observed in the hypolimnion. High water inflows were beginning to occur while water releases decreased; at the same time a peak in biovolumes of Cryptomonas sp. occurred in the epilimnion.

Ammonium nitrogen concentrations in the water column were lower than $50 \mu \mathrm{g} / \mathrm{L}$ throughout the sampling period, except for a noticeable increase in the hypolimnetic ammonium during the anoxic period as nitrate+nitrate was reduced. At this time ammonium nitrogen concentration reached a maxima of $195 \mu \mathrm{g} / \mathrm{L}(11 / 13 / 1998)$. With increases in inflows, the concentration of ammonium nitrogen decreased again to low levels

\section{Total Phosphorous and Soluble Reactive Phosphorous}

Total phosphorous concentrations seemed to be controlled by the water levels (inflows) and water $\mathrm{pH}$. Epilimnetic, metalimnetic and hypolimnetic values had similar seasonal patterns. Epilimnetic total phosphorous had a high concentration of $29 \mu \mathrm{g} / \mathrm{L}$ (June 23, 1998), it decreased to $7 \mu \mathrm{g} / \mathrm{L}$ and increased again as low dissolved oxygen conditions occurred in the hypolimnion (Figure 22). 
SRP concentrations were low throughout the water column with epilimnetic concentrations lower than $10 \mu \mathrm{g} / \mathrm{L}$ except in the samples of 6/23/1998 (27 $\mu \mathrm{g} / \mathrm{L})$ and $8 / 4 / 1998(11.23 \mu \mathrm{g} / \mathrm{L})$, and a yearly average value of $5.4 \mu \mathrm{g} / \mathrm{L}$.

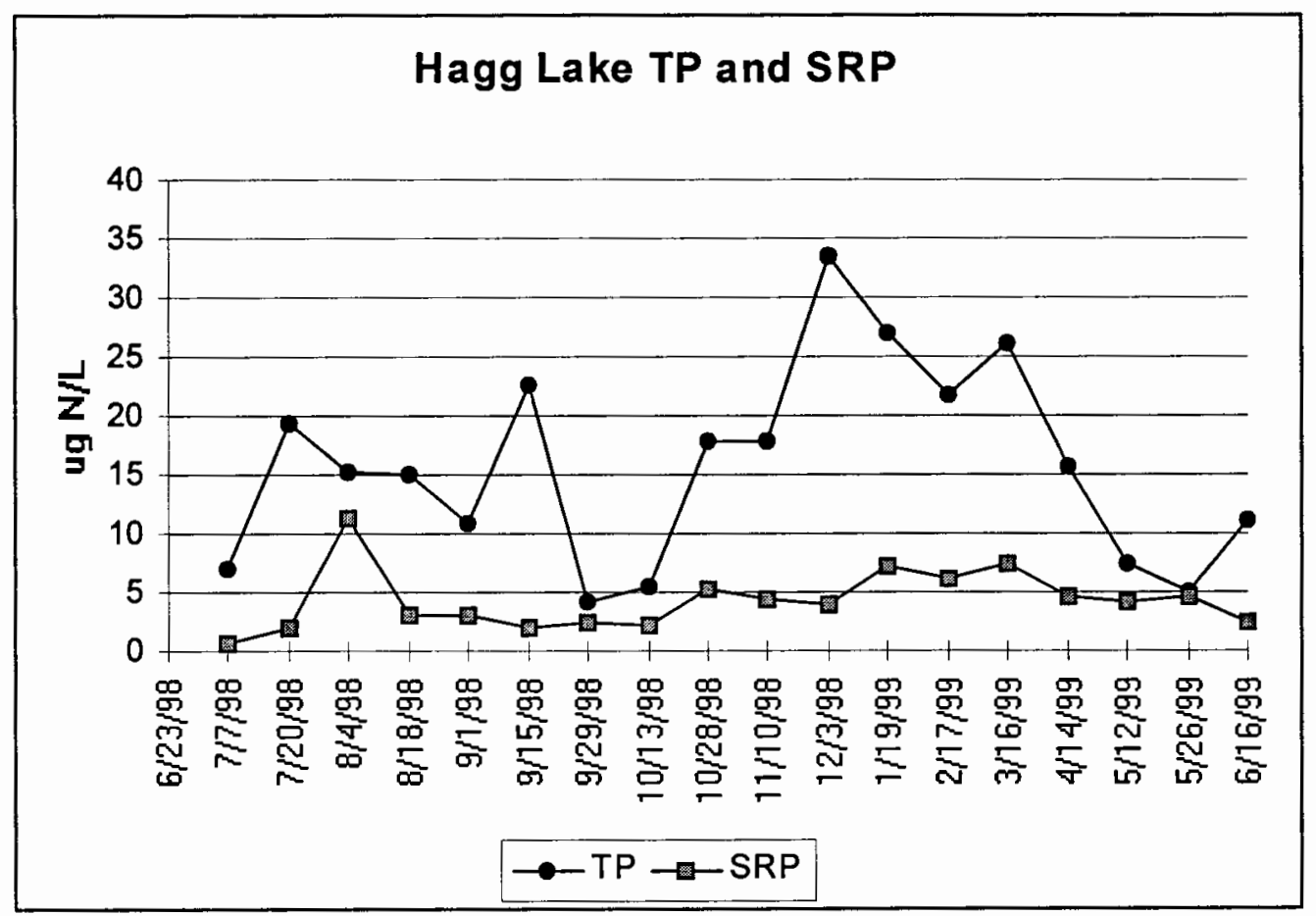

Figure 22. Hagg Lake. TP and Soluble Reactive Phosphorus in $\mu g / L$.

\section{Dissolved Silica}

Silicon was measured as dissolved silica $\left(\mathrm{SiO}_{2}\right)$. Silica concentrations measured in the epilimnion during summer and fall 1998 was lower than the concentrations measured in the metalimnion and hypolimnion (Figure 23). During the winter and spring of 1999 , silica concentrations were similar 
throughout the water column. Annual average silica concentration was measured at $12.4 \mathrm{mg} / \mathrm{L}$ with a single instance of silica 'depletion' on $9 / 29 / 1998$ at $6.9 \mathrm{mg} / \mathrm{L}$. The graph of the total biovolume of the Bacillariophycea (diatoms) did not indicate that silica was a limiting nutrient to this group of algae.

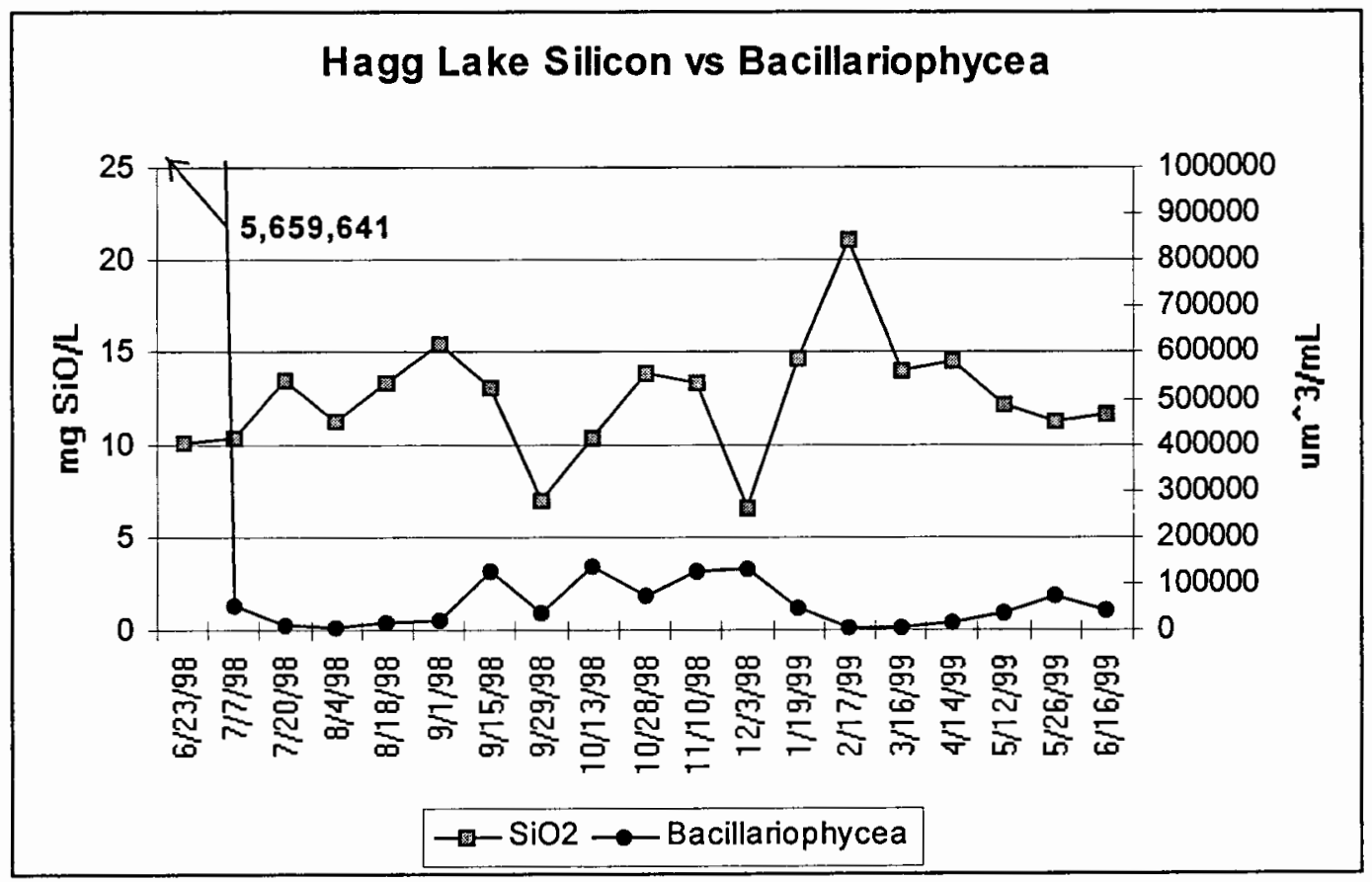

Figure 23. Hagg Lake. Silica(mg/l) and Bacillariophycea biovolumes.

8. Major Dissolved Cations: Sodium (Na), Potassium (K), Magnesium (Mg) and Calcium (Ca):

Epilimnetic concentrations of $\mathrm{Na}, \mathrm{Ca}, \mathrm{Mg}$ and $\mathrm{K}$ followed a pattern similar to that of the conductivity (Figure 24a). $\mathrm{Na}, \mathrm{Ca}$, and $\mathrm{Mg}$ 
concentrations were greater than $1 \mathrm{mg} / \mathrm{L}$. The concentrations of $\mathrm{K}$ never reached beyond $0.4 \mathrm{mg} / \mathrm{L}$.

Ca had greater concentrations from June to December 1998 with high concentrations in July and November, followed by a decrease $(1.7 \mathrm{mg} / \mathrm{L}$ in Feb. 1999) and a slow increases afterwards.

Na concentrations were greater from June and December 1998 with higher concentrations in September 1998 (6.5 mg/L in 9/29/1998), followed by a decrease in February 1999 (2.78 mg/L) and a slow increase in concentration.

$\mathrm{K}$ had an initial concentration of $0.34 \mathrm{mg} / \mathrm{L}$ and a low concentration of $0.14 \mathrm{mg} / \mathrm{L}$ in September. Overall, the concentrations of $\mathrm{K}$ from June to December 1998 were greater than the winter and spring 1999 concentrations.

Concentrations of $\mathrm{Mg}$ were greater from June and December 1998 with a high concentration in November 1998 ( $2.45 \mathrm{mg} / \mathrm{L})$, followed by a decrease in February 1999 (1.2 mg/L) and slow increase in concentration.

Late spring, summer and fall 1998 concentrations were higher that winter concentrations. This could have been the result of outflow levels that were kept constant while inflows diminished rapidly. Another possibility is that as the sediments settled, the temperatures rose, and changes in $\mathrm{pH}$ and redox potential occurred in the reservoir, more cations were released from 
the suspended sediments (Thornton et al., 1984), increasing their summer and fall concentrations. Winter inflows did not cause an increase in the ionic concentrations of these cations.

Major anions were not measured consistently during this study, and only two samples from Hagg Lake are reported here (Figure 24b). Dissolved chloride concentration measurements were lower than the chloride measurement of Barney Reservoir and the dissolved sulfate concentrations were higher than in Barney Reservoir.

\section{Trophic State Indices (TSI)}

The seasonal variation in epilimnetic TSI was calculated using the formulae proposed by Carlson (1977). Figure 25 portrays these variations for TSI for Secchi depth, Chlorophyll-a and Total Phosphorous.

The calculated TSI for Secchi depth had an average of 50.8, with a June-November 1998 average of 45.2 and a December 1998-June 1999 average of 58.4 units. TSI for Secchi depth achieved its highest value of 73.2 units in March 1999. The pattern of TSI for Secchi depth followed the pattern of the turbidity values and increased with the fall and winter increases in inflows to the reservoir.

The calculated TSI for Chlorophyll-a had an average of 36.2, with a summer 1998 low of $9.7(7 / 20 / 1998)$ and a winter low of $14.2(2 / 17 / 1999)$. 


\section{Hagg Lake Major Cations}

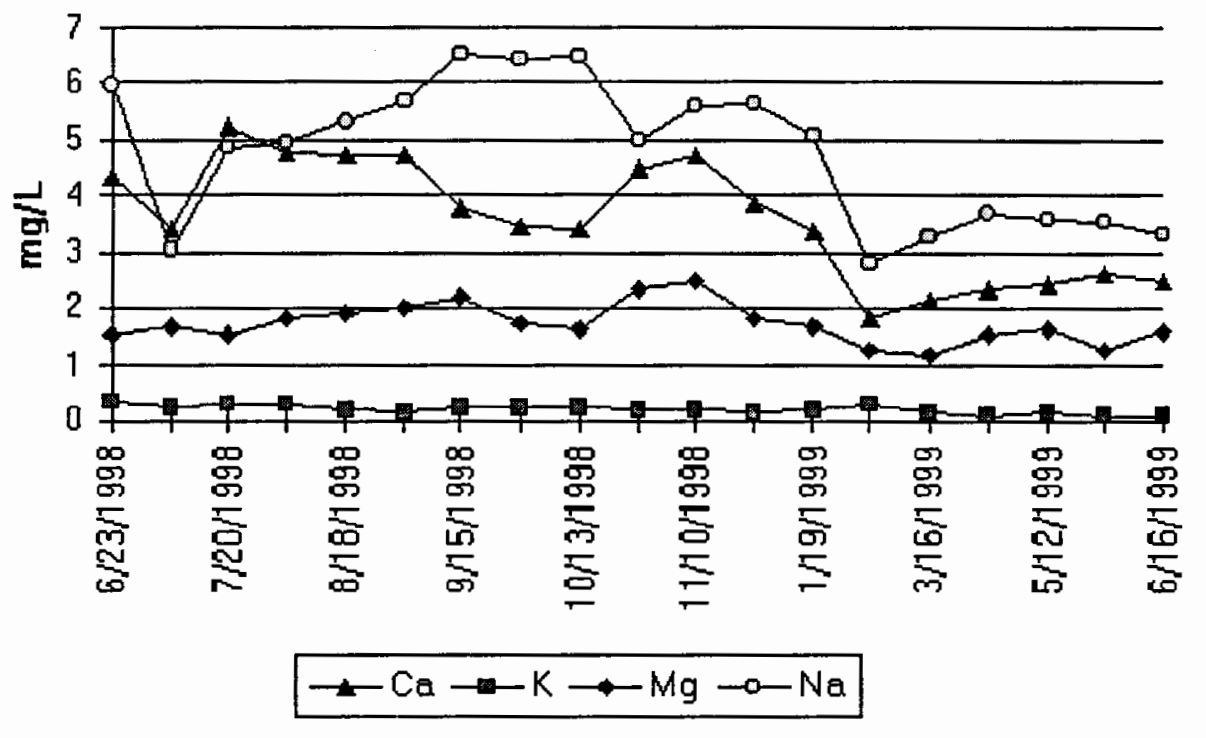

Figure 24a. Hagg Lake. Cations: $\mathrm{Na}, \mathrm{K}, \mathrm{Mg}$ and $\mathrm{Ca}(\mathrm{mg} / \mathrm{L})$.

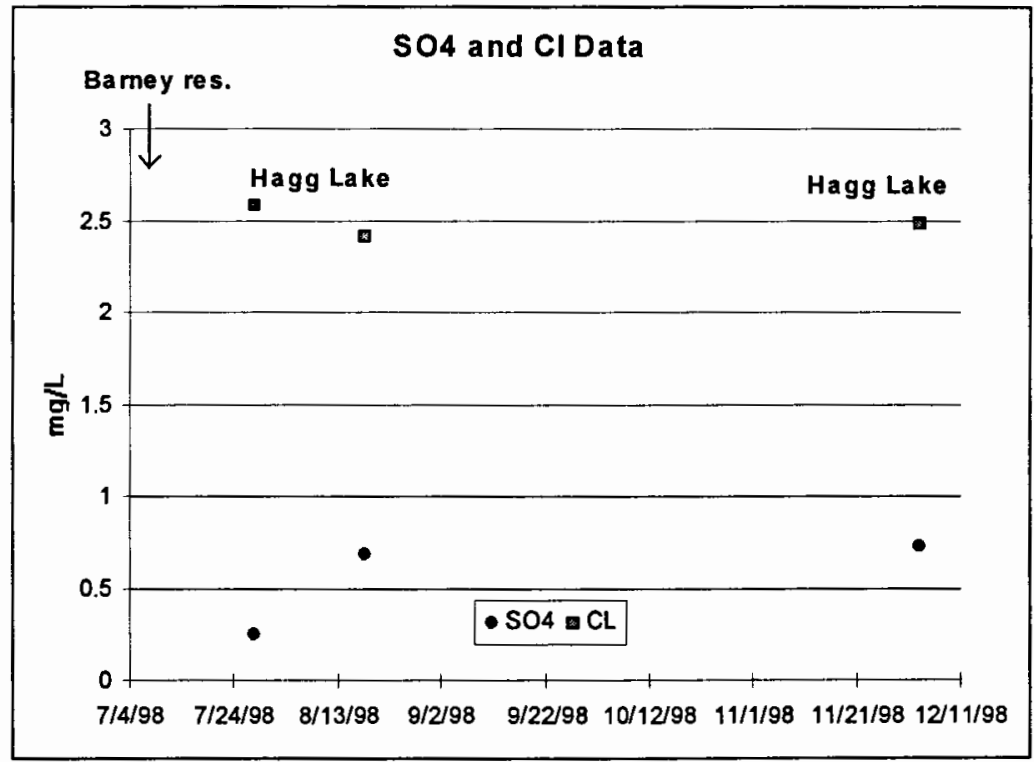

Figure 24b. Hagg Lake. Anions: $\mathrm{Cl}$ and $\mathrm{SO}_{4}(\mathrm{mg} / \mathrm{L})$. 
In the former case, the low chlorophyll-a also coincided with the highest photic depth. The June-November 1998 average TSI for Chlorophyll-a was 35.4; the December 1998-June 1999 average was 37.7 units. The early bloom of Synedra radians and Fragilaria crotonensis in June 1998 made the TSI for Chlorophyll-a achieve its highest value of 56.9 units, while late summer increases of Chlamydomonas, Cryptomonas and other small bodied autotrophs caused the TSI Chlorophyll-a to reach 49.1 units

The average TSI for Total Phosphorous for this study period was of 42.1 units with a June-November 1998 average of 41.0 and a December 1998June 1999 average of 43.6 units. The summer low was of 24.9 with an increase at the end of fall (54.8 units, 12/3/1998) and a decline beginning in March 1999.

Single measurements of Secchi depth, Chlorophyll-a or Total Phosphorous are misleading when classifying this reservoir according to classifications based on trophic indices. Yearly or summer averages of these trophic status indices could be more reliable. According to Carlson (1977) and Johnson (1985), and based on the data, Hagg Lake can be classified as reservoir with a mesotrophic lacustrine zone, with summer and winter oligotrophic periods (according to the TSI-Chlorophyll-a), winter eutrophic periods (according to the TSI- Secchi depth), and winter eutrophicmesotrophic periods (according to the TSI-Total Phosphorous). 


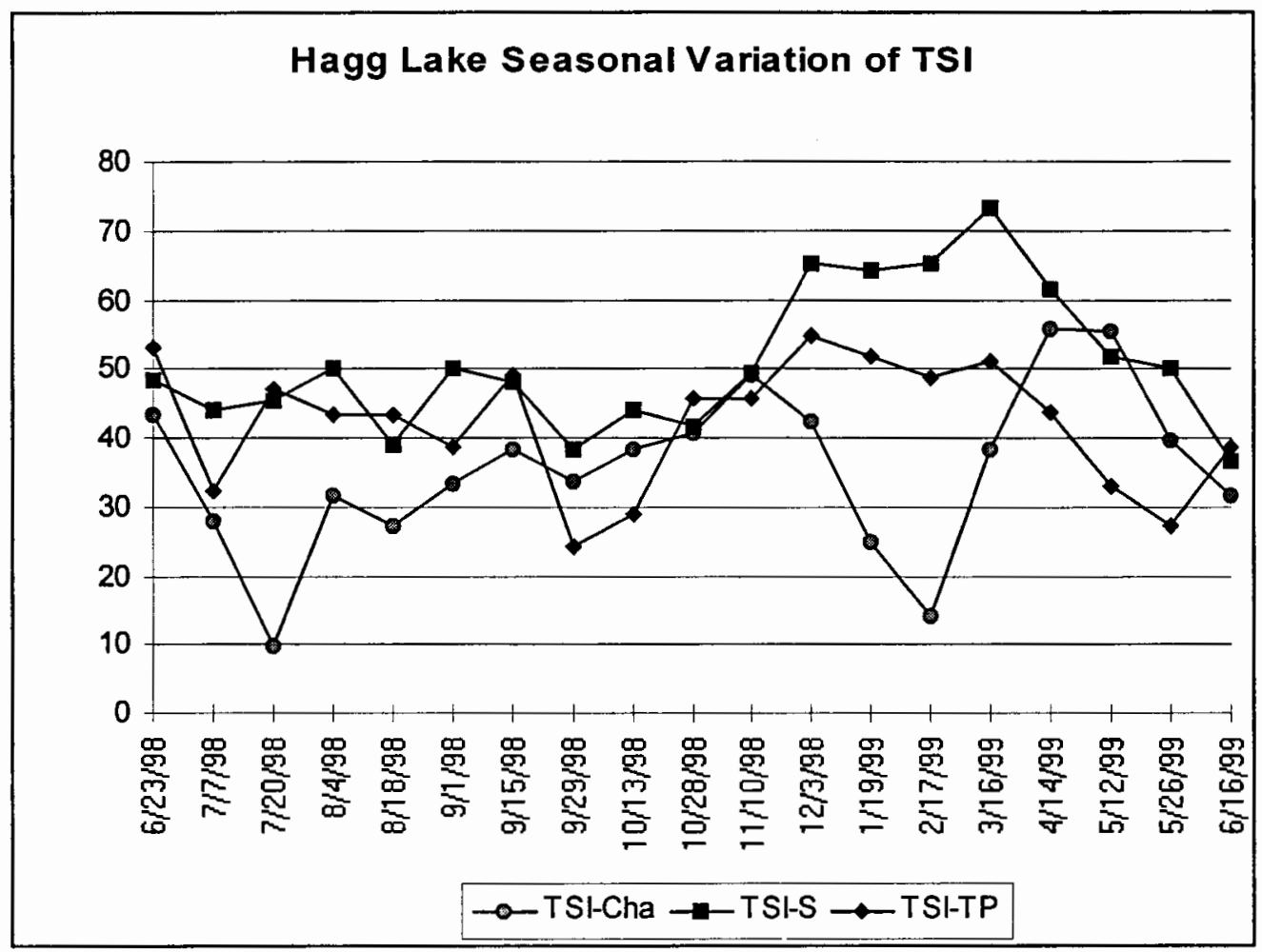

Figure 25. Hagg Lake. Seasonal epilimnetic variations in Trophic State Indices.

\section{Nutrient Ratios}

The average value of the epilimnetic total nitrogen - total phosphorous (TN:TP) mass ratios was 11.5 with a low value of 3.2 during the summer 1998 and a high TN:TP ratio in July and October 1998, and winter 1999. Reynolds (1984) suggested that nitrogen stress occurred at TN:TP ratios of 7 or less. However, in Hagg Lake the TN:TP ratio of 7 was surpassed in 12 of the 19 samples. A late spring, a late summer and high winter peaks 
occurred at the same time species dominance changed or decreased. Thus, the late spring peak preceded the clear water phase, (highest photic depth); the late summer peak occurred at the same time anoxic conditions were occurring in the hypolimnion and as rains began. The winter peaks coincided with high inflows from the creeks that feed this reservoir. By the end of the spring of 1999 the TN:TP ratio decreased again.

The low TN:TP ratios of the summer of 1998 were accompanied by increases in Dinobryon sertularia and slight Anabaena flos-aqueae biovolumes, the late summer high $\mathrm{N}: \mathrm{P}$ ratios coincided with increases in the biovolumes of Chlamydomonas sp. (Figure 26).

The average silica-total phosphorus mass ratios (Si:TP) were 1022 (Figure 26). Si:TP mass ratios did not seem related to the dynamics of the Bacillariophycea (Diatoms), except perhaps for a short period in the late summer of 1998 when the mass ratio was 1884 (10.4 mg Si/L, 10/13/1998) and an increase in the biovolume of Asterionela formosa was observed, followed by an increase in the biovolumes of Melosira varians when the ratio diminished to 194 (6.53 $\mathrm{mg} \mathrm{Si} / \mathrm{L}, 12 / 3 / 1998)$. Another peak of the Si:TP ratios in May 1999 was also accompanied by an increase in the biovolumes of Fragilaria crotonensis ( $6.53 \mathrm{mg} \mathrm{Si} / \mathrm{L}, 5 / 26 / 1999)$. The silica in this particular reservoir did not seem to be a limiting nutrient for the phytoplankton. 


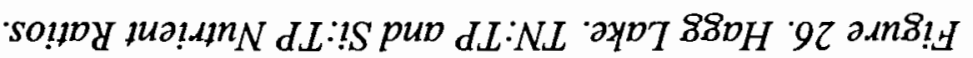

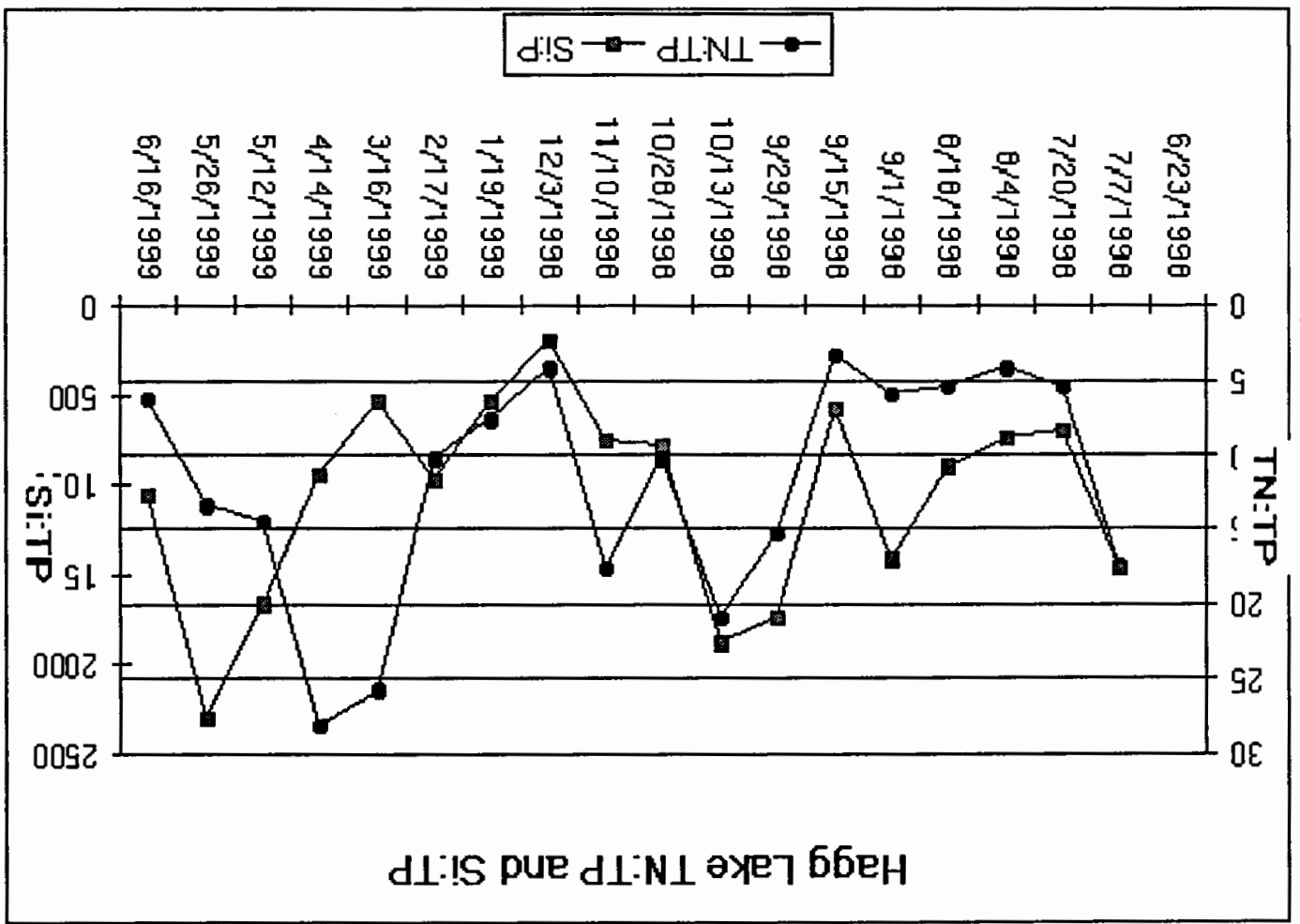




\section{c) Biological factors}

\section{Phytoplankton}

Ten species contributed to $95.6 \%$ of the total annual biovolumes (Table 4), seven of these formed colonies (including Asterionela formosa and Synedra radians), and four of them had at times biovolumes that coincided with smaller peaks in chlorophyll-a (Figure 27). In June 1998 a bloom of Synedra radians and Fragilaria crotonensis contributed to the higher chlorophyll-a measurements. This bloom was followed by a bloom of Dinobryon bavaricum (7/20/1998). An increase in Cryptomonas sp. biovolumes in the sample of November 11, 1998 occurred at the same time chlorophyll-a readings were $6.67 \mu \mathrm{g} / \mathrm{L}$; another Cryptomonas sp. increase in May 1999 corresponded to $12.8 \mu \mathrm{g} / \mathrm{L}$. An increase in the biovolumes of Chlamydomonas $s p$. caused the next highest chlorophyll-a reading $(13.1 \mu \mathrm{g} / \mathrm{L})$. 


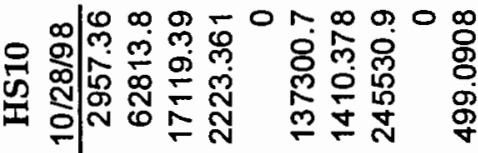

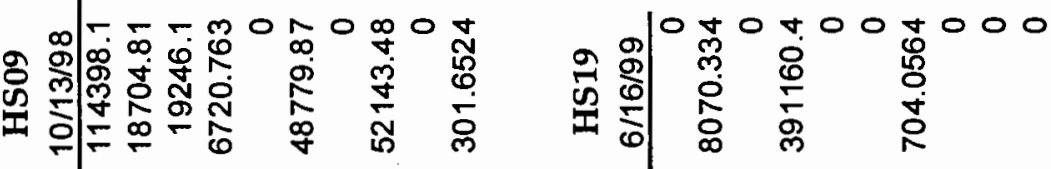

$\pi+\infty \pi+z 0 m$

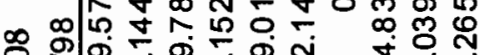

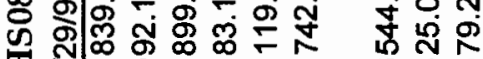

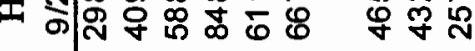

م

फ

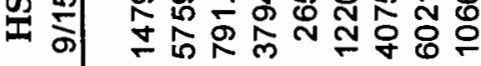

ㅇํำㅇำ

号

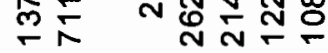

กั

ᄂ

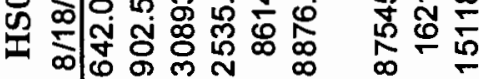

○ भ

ఫ

守

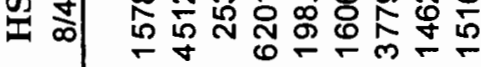

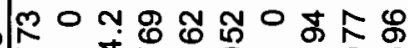

m \% प्र

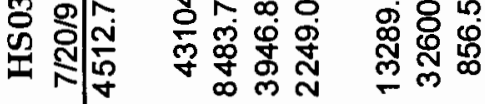

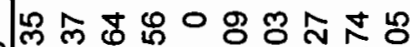

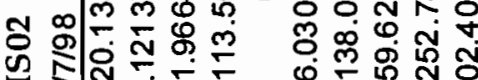

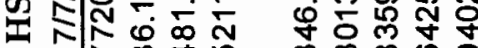

on ONoONON

ร

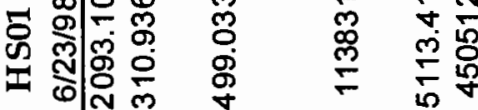

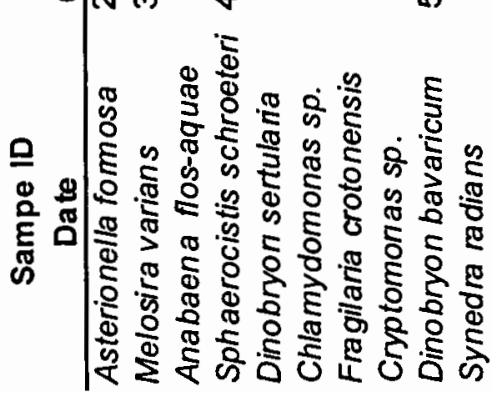




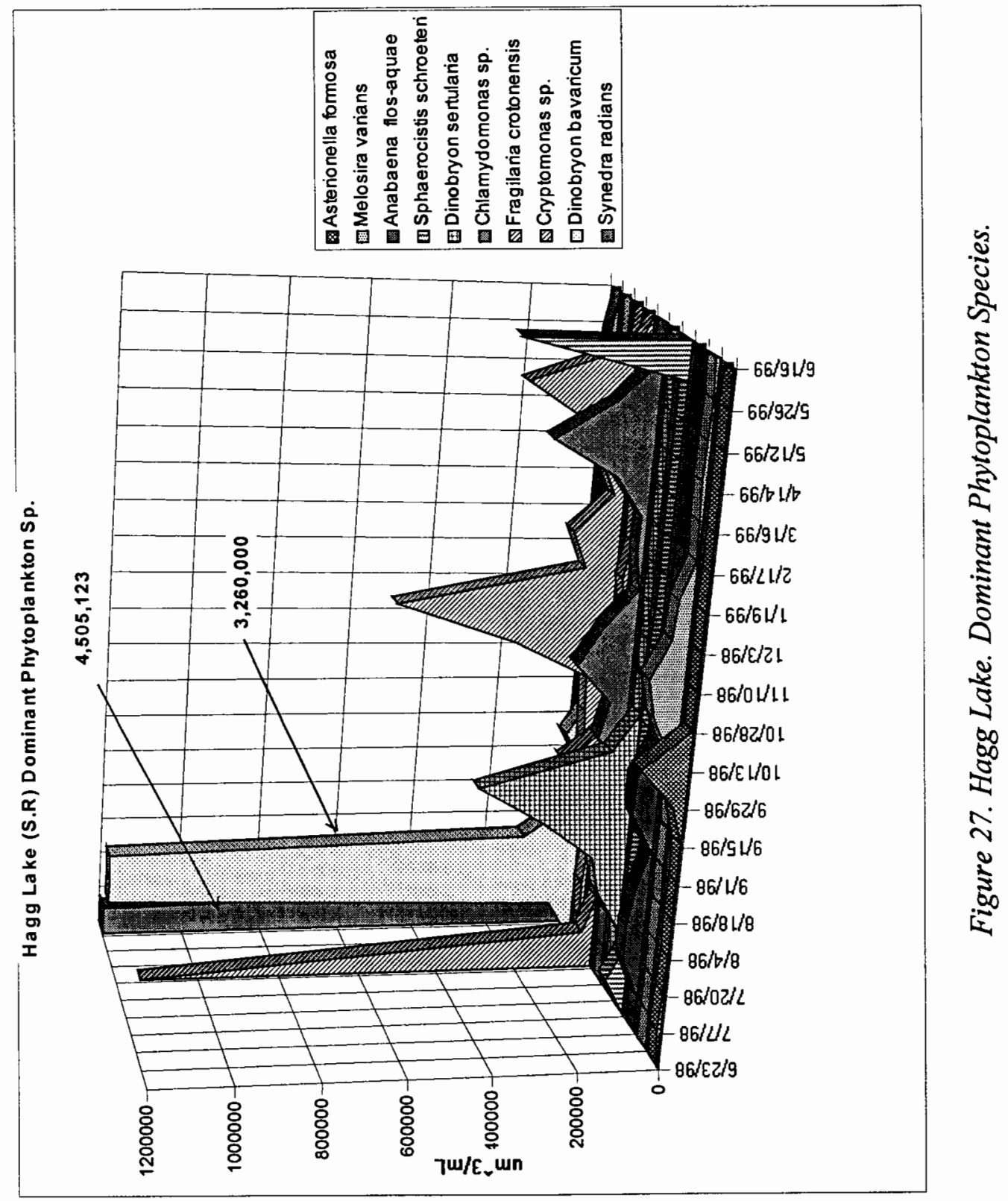


The dominant species by biovolumes belonged to the Bacillariophycea and Chrysophycea Classes, with contributions of species from the Chlorophyta, Cryptophyta and Cyanophyta and Dinoflagelates. The species forming colonies or cenobia dominated the biovolume totals from spring to early fall 1998. With lower temperatures and the decrease in the number of large grazers, individuals dominated the phytoplankton succession until June 1999 (Figure 28). Individuals were represented by Melosira varians, Chlamydomonas sp. and Cryptomonas sp. The dominance of these individual species coincided with a decrease in the biovolumes of omnivores (including nauplii of cyclopoids and calanoids), grazers (eucladocerans) and increases in turbidity and mixing of the water column. 


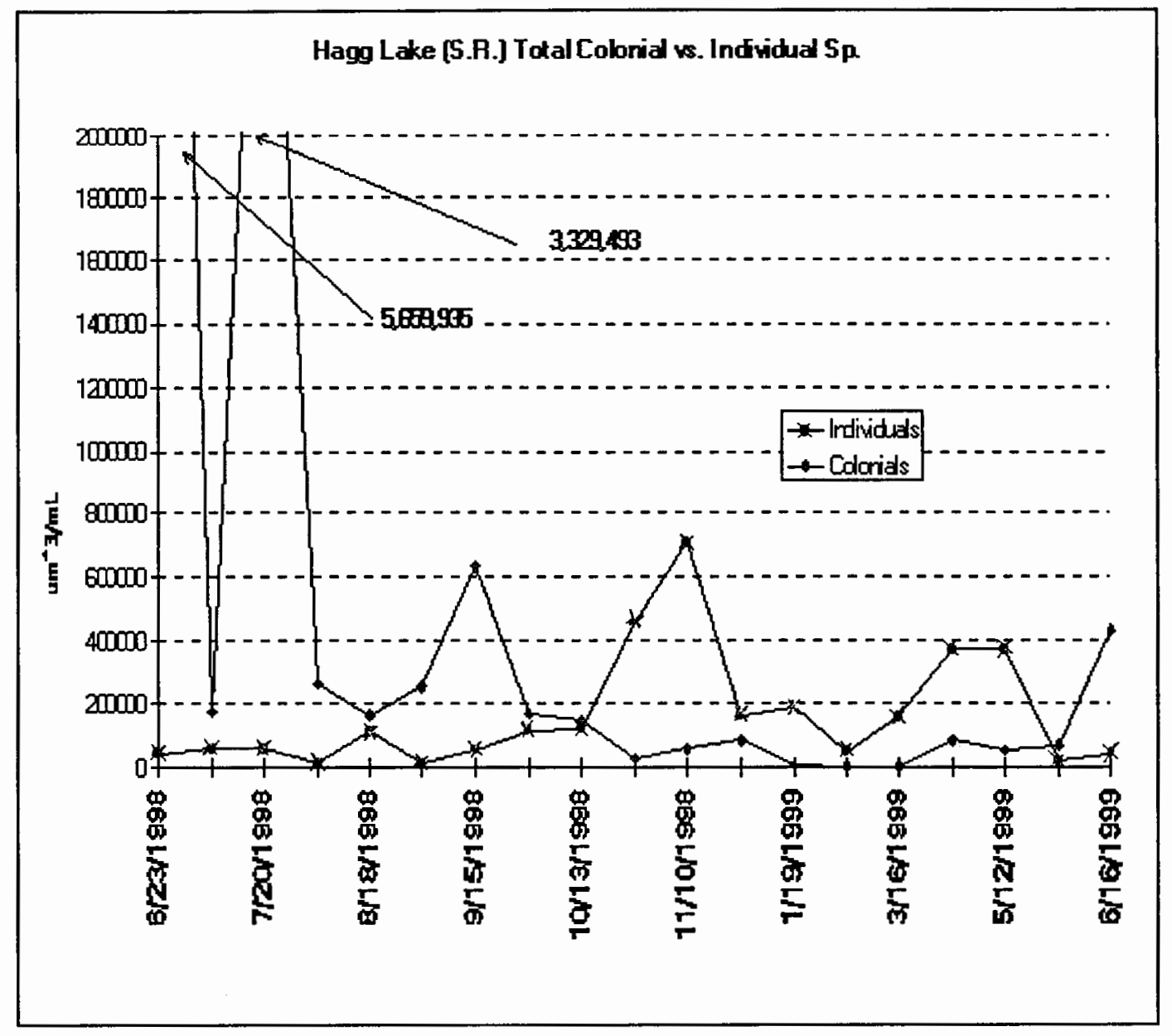

Figure 28. Hagg Lake. Total colonial vs. individual phytoplankton species.

\section{Zooplankton}

Five species of organisms, including calanoid and cyclopoid nauplii, dominated the total zooplankton biovolumes in Hagg Lake (Figure 29 and Table 4). The phyla and classes encountered were protozoans, eucladocerans, calanoids, cyclopoids and rotifers. They were grouped according to their feeding habits: raptorials, filter feeders, omnivores (including the nauplii in 
the omnivores group) and grazers. In the spring of 1998 and 1999 raptorial zooplankton and its cohort of nauplii and copepodites dominated the succession of zooplankton. During the summer 1998, fall 1998 and winter 1999 the filter feeders, grazers and omnivores (non-predators) had lower biovolumes when compared to predatory zooplankton. 


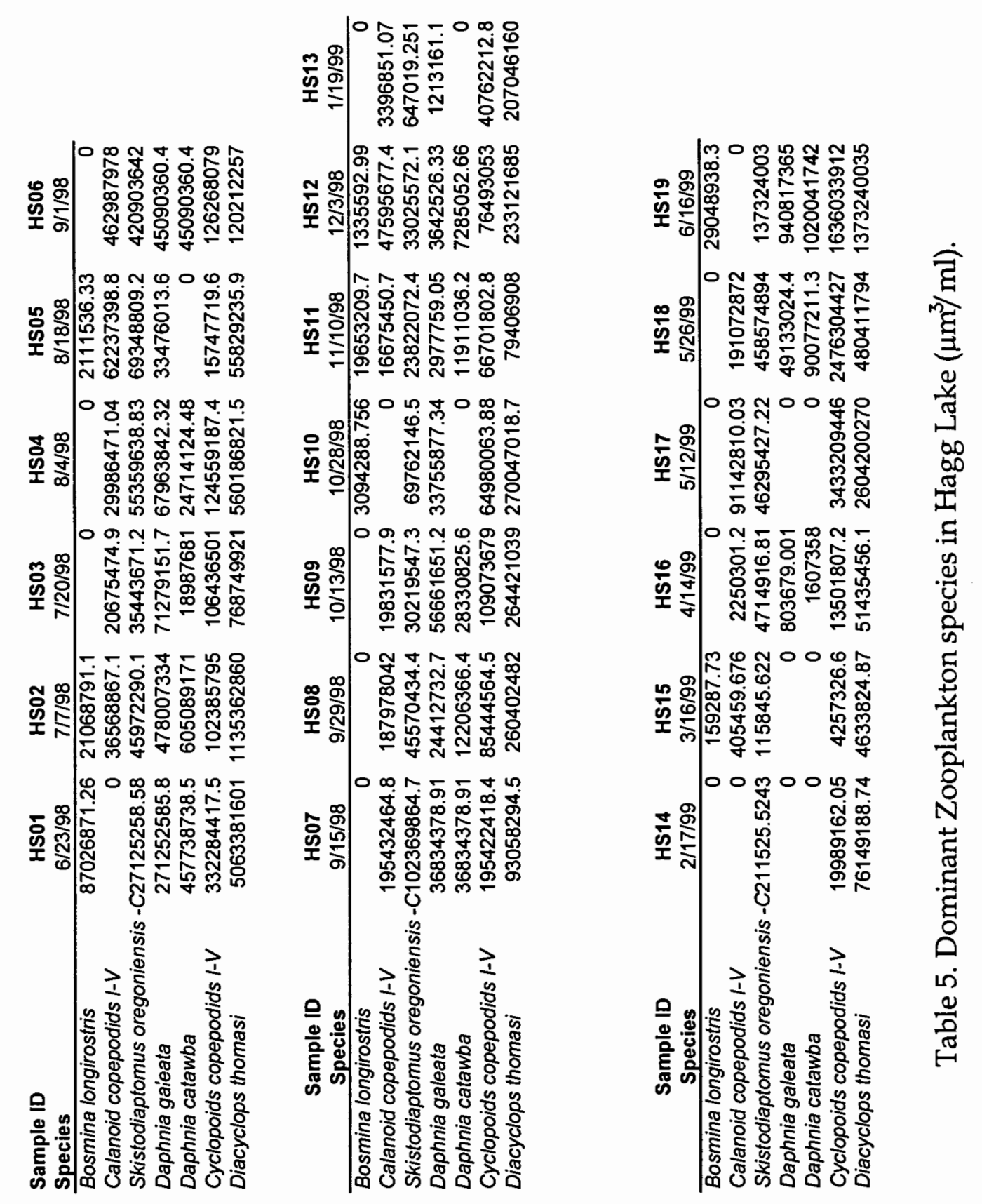




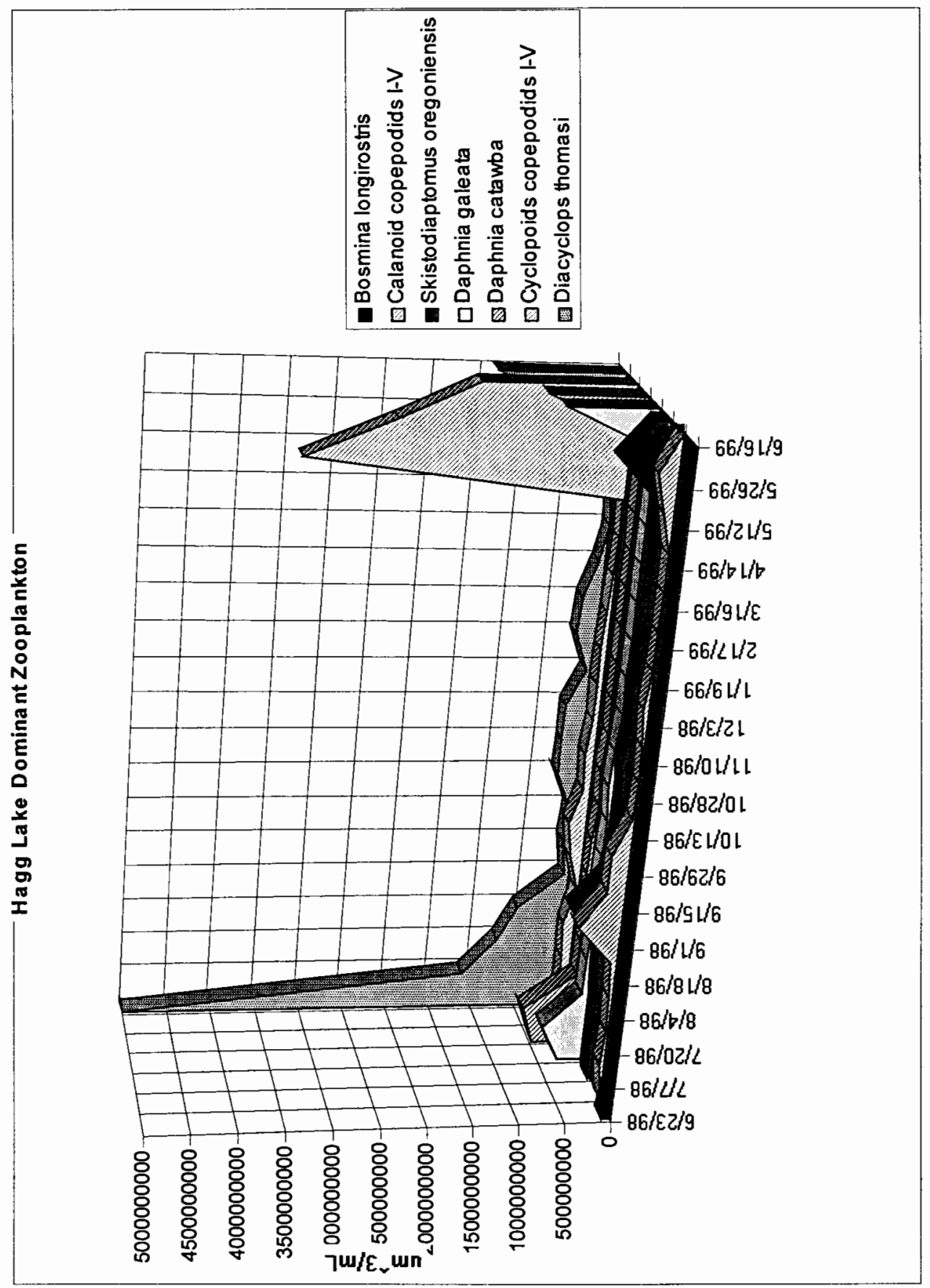

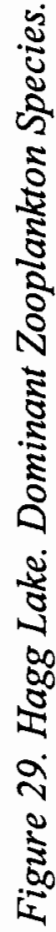


After the biovolume of the predators decreased in August, the biovolumes of the filter-feeders calanoids increased, but fell again. The calanoid decrease occurred at the same time that there was a slight increase in the biovolume of the predators, and a decrease in the total biovolumes of the phytoplankton (Figures 30 and 28).

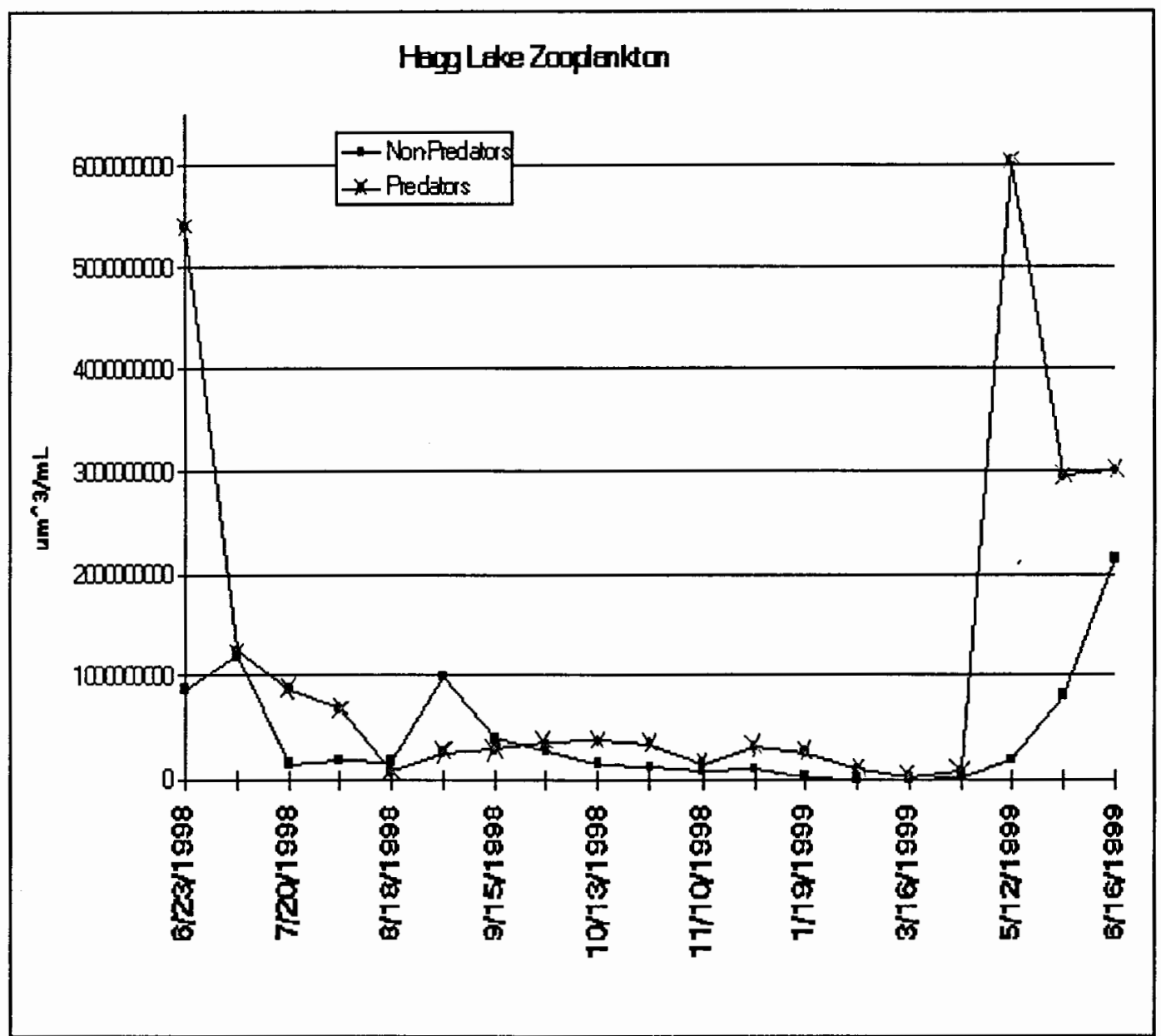

Figure 30. Hagg Lake. Predator vs. Non-predatory Zooplankton Biovolumes. 
When the large herbivorous zooplankton and the small zooplankton species are considered apart from the large, raptorial cyclopoids, there is a clear succession from the large daphnia to calanoid species. The smaller rotifers and protozoans have a more varied succession pattern with Polyarthra dolichoptera increasing at the same time larger herbivores biovolumes increase, and Synchaeta sp. showing peak values in June and December 1998 (Figure 31a and 31b).

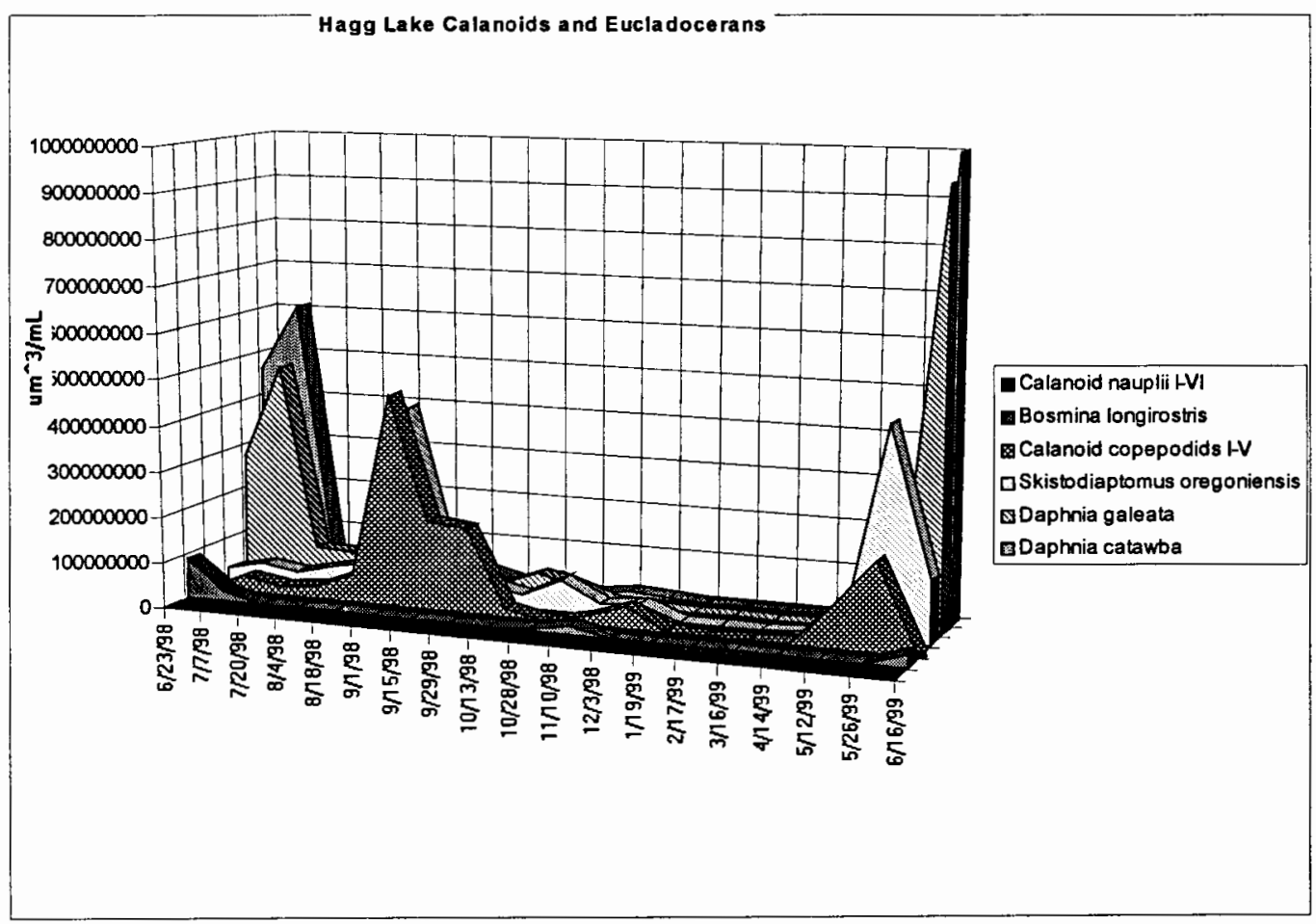

Figure 3la. Hagg Lake. Calanoids and eucladocerans biovolumes. 


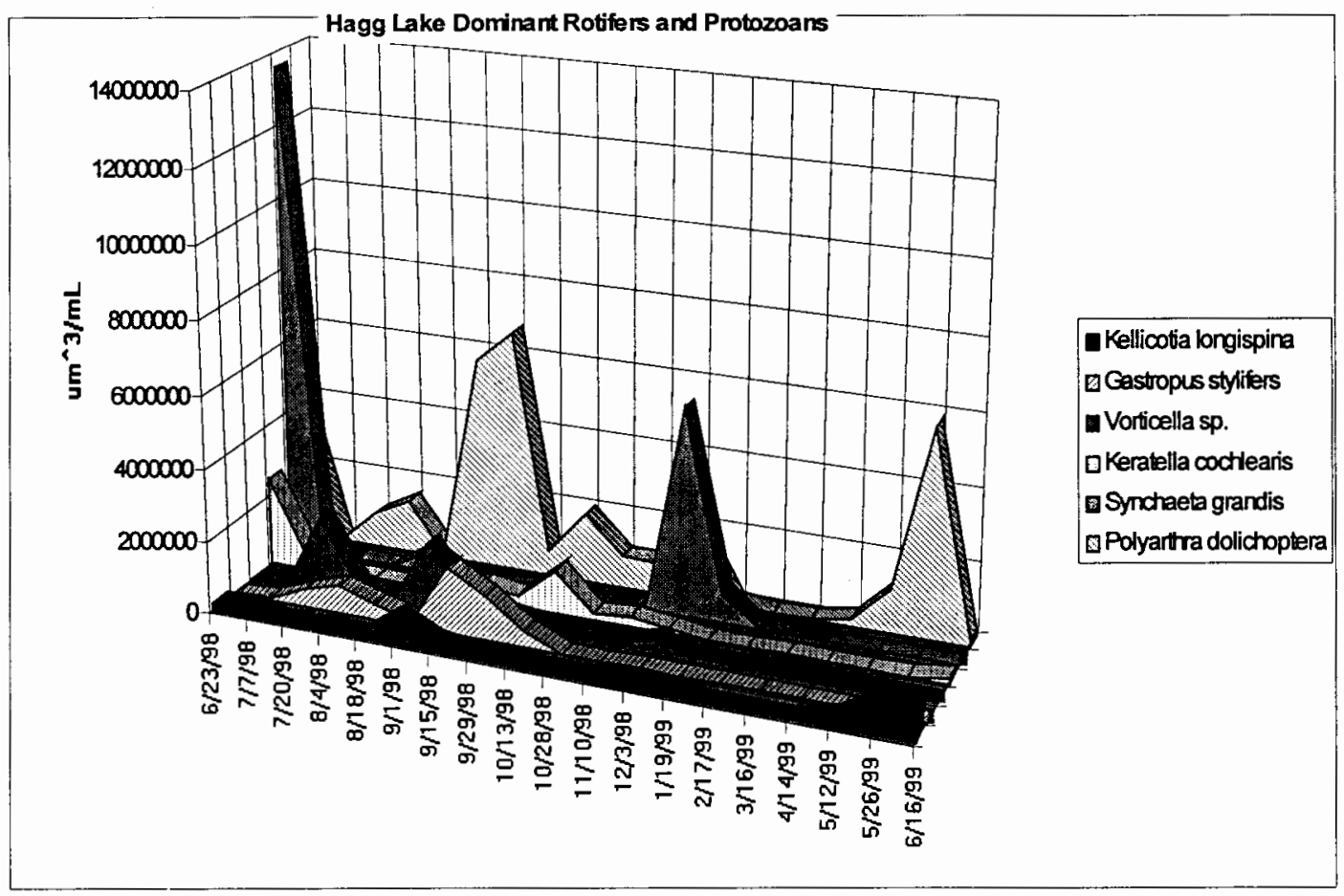

Figure 31b. Hagg Lake. Dominant Rotifers and protozoans.

\section{Fish predation}

The Oregon Department of Fish and Wildlife (George Nandor, personal communication) reports that from May to June 1998 and on 6/2/1998, rainbow trout (Oncorhynchus mykiss gairdneri) fingerlings were introduced in Hagg Lake, adding up to a total of $8,778 \mathrm{Kg}$, and that on September 9, 1998, 589.6 Kg of winter steelhead (Oncorhynchus sp.) were introduced. 
In 1999, from January to March $19985,100 \mathrm{Kg}$ of steelhead fingerlings were liberated in Hagg Lake. From May to June 1999 and on 6/1/1999, 9,908 $\mathrm{Kg}$ of rainbow trout fingerlings were introduced in Hagg Lake.

The impact of fish on the zooplankton and phytoplankton was not measured directly. However, I infer that when fish are small in size, they will feed on some of the larger zooplankton (June 1998, September 1998 and May 1999 declines of larger zooplankton), and in turn the disappearance of the larger zooplankton will allow smaller zooplankton to thrive (Stewart, 1980), (Figure 29).

\section{Species diversity}

In this study, the Shannon-Weiner index of diversity was used to measure the information content of the samples. The Shannon-Weiner index is used here to explore the diversity-stability relationships, with the understanding that diversity is an aspect of the community and stability is an aspect of the community functions (Washington, 1984). The ShannonWeiner function described by:

$\mathrm{H}^{\prime}=-\sum_{i=1}^{s}\left[\left(p_{i}\right) \cdot\left(\log _{2} p_{i}\right)\right]$ or $\mathrm{H}^{\prime}=-\sum_{i=1}^{s}\left[\left(p_{i} \cdot \operatorname{Ln}\left(p_{i}\right)\right) / \operatorname{Ln}(2)\right]($ formula 1.0) Were $s=$ number of species, $p_{i}=$ proportion of that species over the total value in a sample (Washington, 1984). 
Reynolds (1984) suggested that diversity indices using biovolumes instead of cell counts could be more sensitive to changes in dominance. Thus, in this thesis, $p_{i}=$ proportion of the biovolume of the species $i$ over the total biovolume in a sample.

The calculated values of this index, for zooplankton and phytoplankton in Hagg Lake, are given in Figure 32a. The average diversity measured was 1.77 bits per individual for the zooplankton and 1.80 for the phytoplankton.

The graph shows that the Shannon-Weiner index for the phytoplankton decreased at the same time dominance of one or two species (Dinobryon sp., Synedra radians) occurred, and increased as these species ceased to dominate and were replaced by smaller and non-colonial forms (Fall of 1998).

The zooplankton index followed a different trend with increases in its value as the summer and fall contribution of smaller bodied zooplankton increased. The diversity index value declined during the winter as the biovolume contribution of the species decreased and high inflows, wind mixing, high turbidity and low temperatures occurred.

The normalized evenness or redundancy with a range of 0 to 1.0 was calculated as well, with 1 indicating even samples (many co-dominant species). In Hagg Lake, the average value of evenness was 0.27 for 
phytoplankton, with low values in June and July as the biovolumes of phytoplankton were dominated by few species, and high values in late summer and in February as the contribution of each phytoplankton species to the total biovolumes more uniform. The zooplankton evenness values had fewer variations, with an average of 0.24 and a maximum in October 1998 of 0.54 , and a minimum in January 1999 when few species were present and dominance by biovolume contribution was by one of them (Figure 32b).

The Shannon-Weiner index and the normalized evenness reflect the succession characteristics of Hagg Lake. Thus, when a 'bloom' of a species of algae creates drastic variations from one sample to the next, the change in the values of these metrics lead us to infer that other mechanisms (resource competition, settling out of the water column) and not grazing control these variations. In the case of zooplankton, the decrease but not total removal from the water column of some species allows other groups to thrive without creating extreme changes in the values of these metrics from one sample to the next.

The relevance of the Shannon-Weiner and the normalized evenness metrics in this study stems from the fact that it is through the seasonal observations of the changes of these metrics that other explanations regarding the relationships between biotic and abiotic factors are reinforced. 


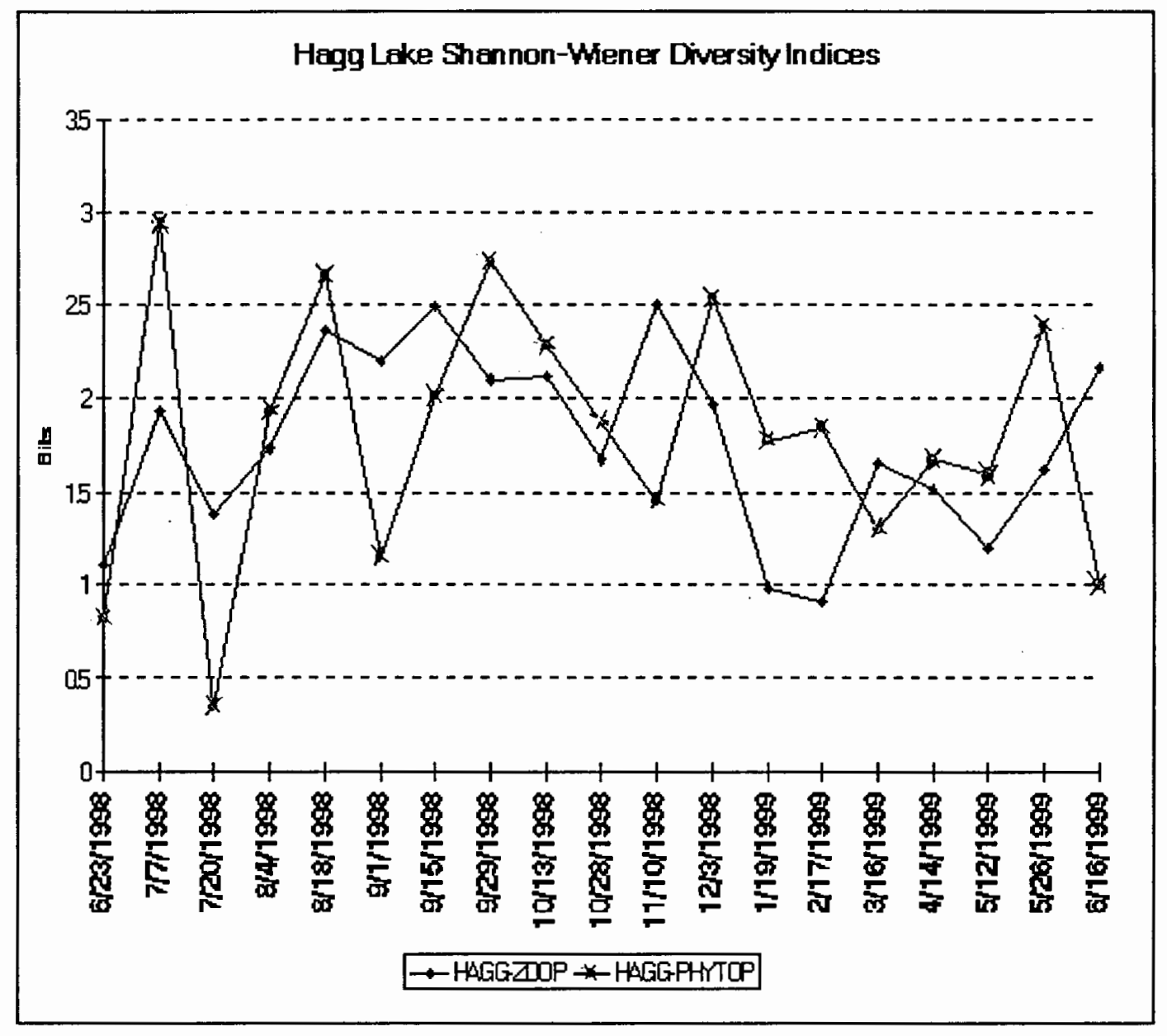

Figure 32a Hagg Lake. Shannon-Weiner Species Diversity Index. 


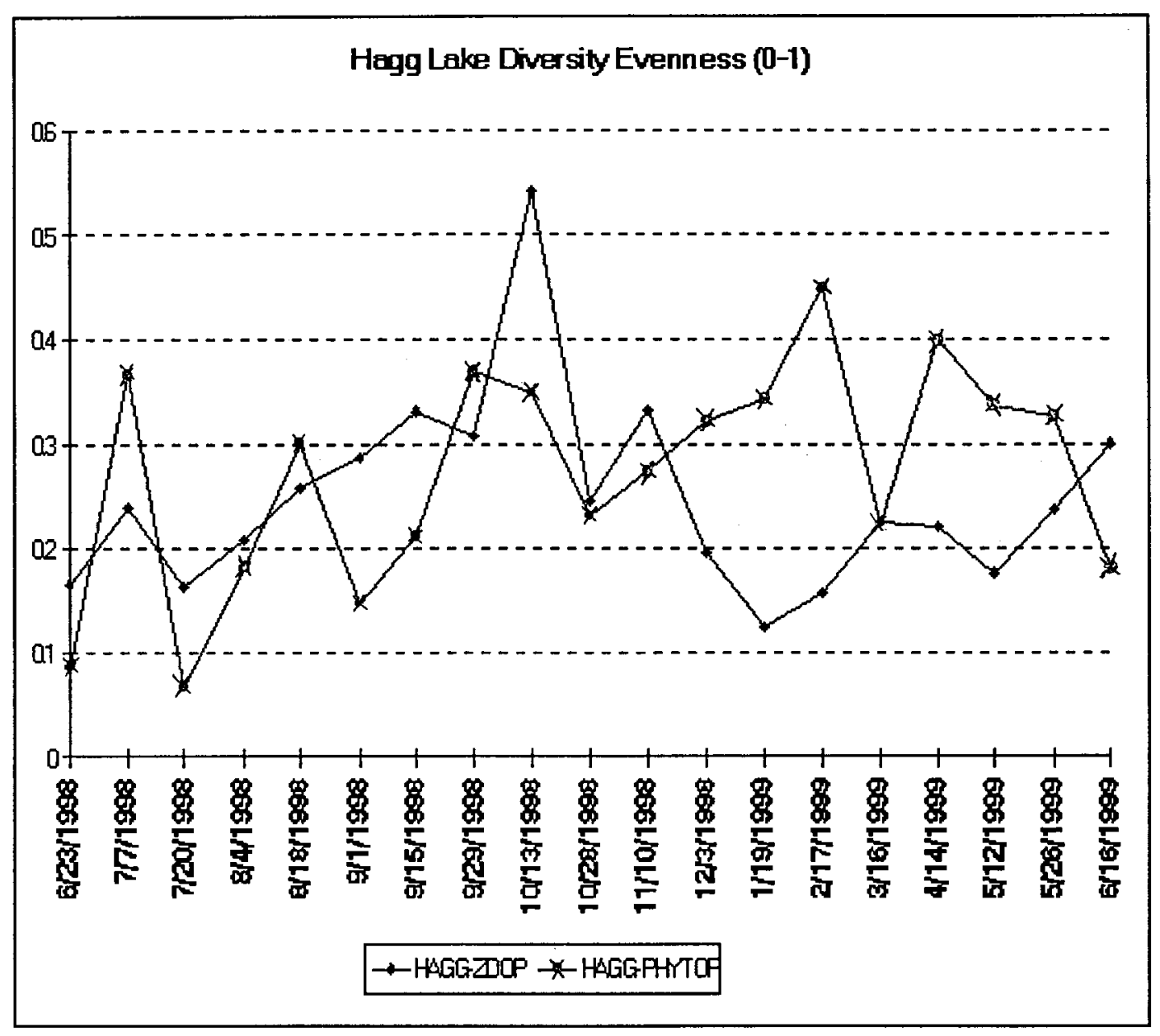

Figure 32b Hagg Lake. Normalized (Diversity) Evenness. 


\section{BARNEY RESERVOIR}

In this section the physical, chemical and biological factors that were measured during the sampling period are described and analyzed. Table 9a and $9 \mathrm{~b}$ list a summary of descriptive statistics for Barney Reservoir data. Microphotographs of selected specimens of the plankton are presented in figure 61 .

\section{a) Physical Factors}

\section{Water Inflows and Outflows}

Barney Reservoir inflows were not measured but observations indicated that the sources of inflows is varied and that the contribution of small streams reaching the reservoir might be equal or greater than the contributions of the North fork of the Trask River (Figure 33).

The data on the water outflows comes from weekly monitoring reports of the dam operation prepared by the operators at the Forest Grove Water Treatment Plant.

The reservoir, as operated during the study period, had extreme changes in storage volumes (Table 1). It reached a maximum water surface elevation of $497.9 \mathrm{~m}$ a. m. s. 1., and a minimum elevation of $479.1 \mathrm{~m}$ a. m. s. 1 . The difference between maximum and minimum elevation was $18.8 \mathrm{~m}$. The 
difference between minimum storage and maximum storage capacity was $63,394,514 \mathrm{~m}^{3}$.

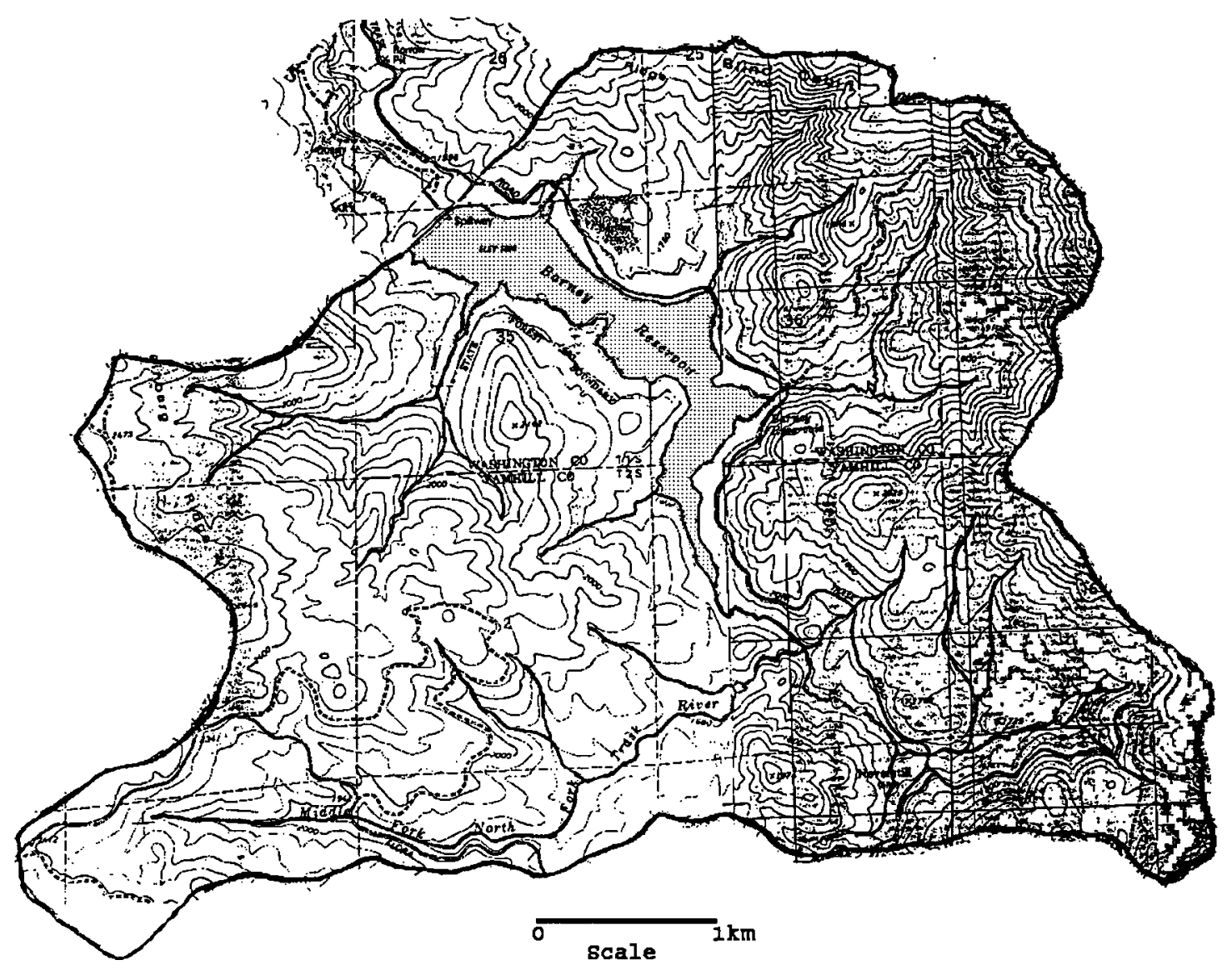

Figure 33. Barney Reservoir and its watershed. (from USGS Maps) 
Due to lack of precipitation data from Barney Reservoir, the precipitation data from Hagg Lake was used as a proxy to help explain the changes in water levels, storage and outflow regime of Barney Reservoir.

The changes in water elevation can be described as follows: from May to June 1998, the water levels remained at a stable elevation (492 $\mathrm{m}$ a. m. s. 1.), and releases were relatively small $\left(65,504 \mathrm{~m}^{3} /\right.$ Day). From June to the end of October 1998, the water elevation decreased steadily to $480 \mathrm{~m}$ a.m.s.l.

From November First to December 15, 1998 as precipitation increased and outflows remained unchanged, the water levels rose $10 \mathrm{~m}$ in this period. By the end of the winter the water level had reached a high of $497.9 \mathrm{~m}$ a. m. s. 1. (3/1/1999). In consequence the outflows were increased to 440,383 $\mathrm{m}^{3} /$ Day. Decreases in precipitation in April 1999 resulted in a sharp decrease in the outflows (19,572 $\mathrm{m}^{3}$ / Day) to keep the water levels at around $490 \mathrm{~m}$. a.m.s.l. until June 1999 (Figure 34a). 


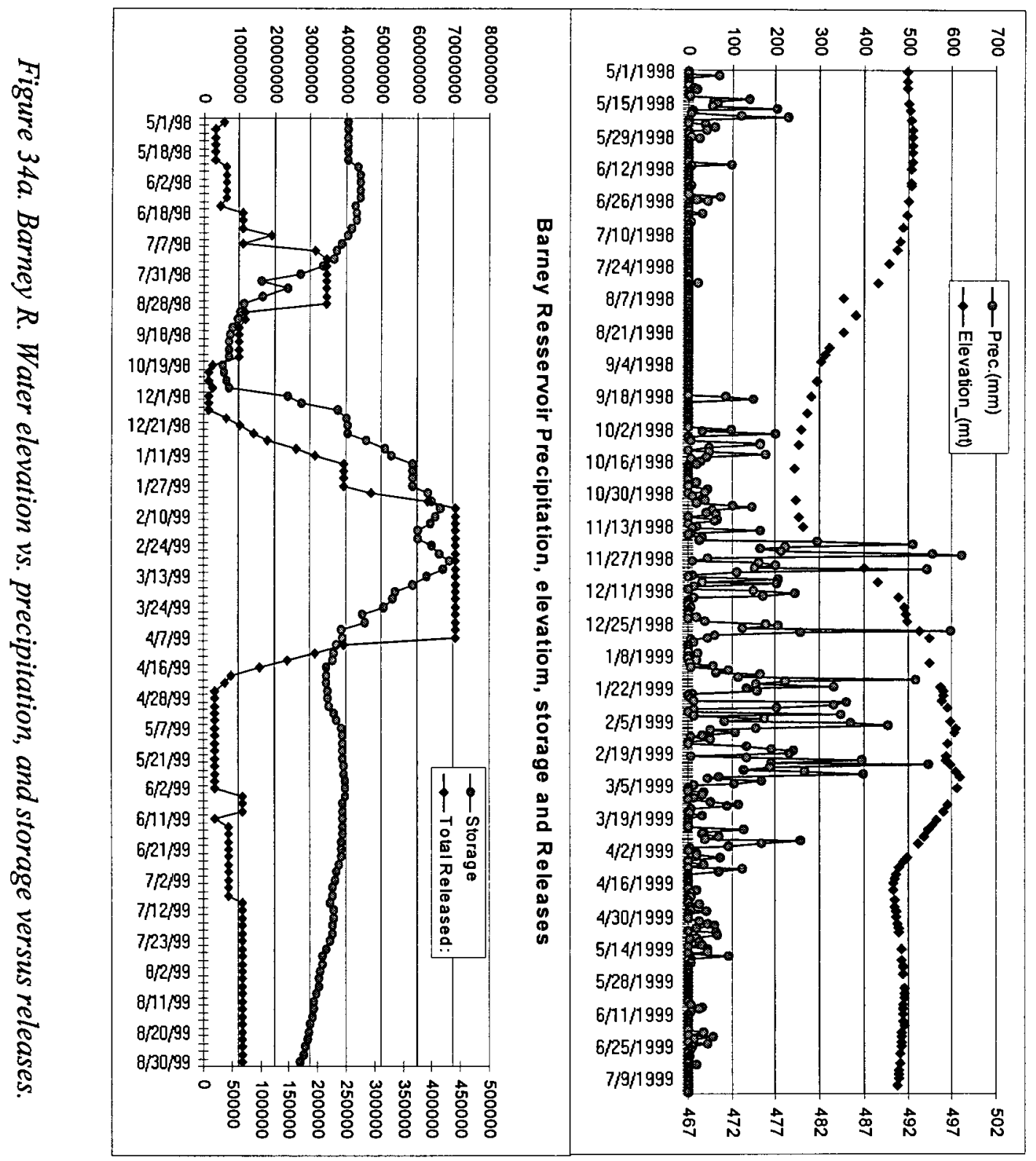


The hydraulic mean residence time was 2.04 years with a high residence time of 10.5 years (December 1998) and a low of 52.6 days (August of 1998). Hydraulic residence time decreased with increases in water releases and vice versa (Figure 34b). The rapid increases in storage capacity in December 1998 and the small releases, made the residence time calculation reach 10.5 years.

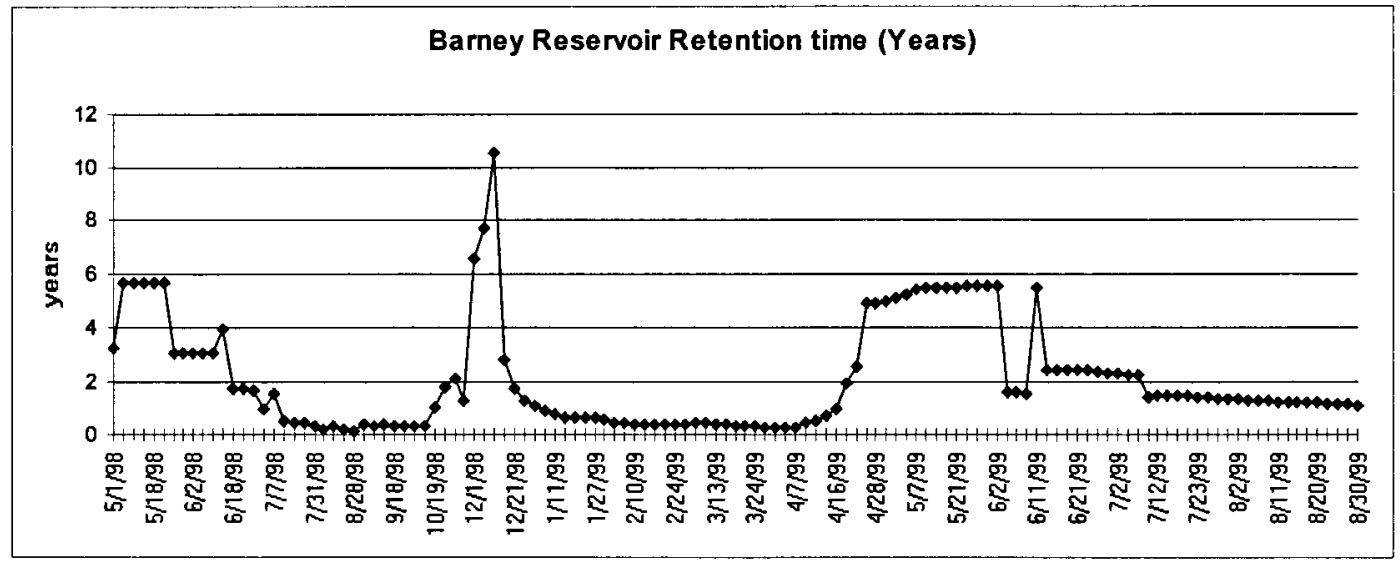

Figure 34b. Barney Reservoir Hydraulic Mean Residence Time in Years.

For a short period in June and July 1998, and in June 1999 the water withdrawals were from the upper epilimnion and metalimnion. In August 1998 the withdrawals were from the epilimnion (Figure 35) until the period when the water column ceased to be stratified. In early November, the water levels were such that the upper portion of the intake structure by the dam 
was visible above the water surface. With increases in the water levels and storage, the water withdrawals were from greater depths. By the end of April 1999, Barney Reservoir became stratified and the water withdrawn was from the newly formed hypolimnion.

This information is significant because it provides the linkage between the stratification stability (temperature), the distribution of dissolved oxygen and other chemical parameters and the changes in the planktonic communities.

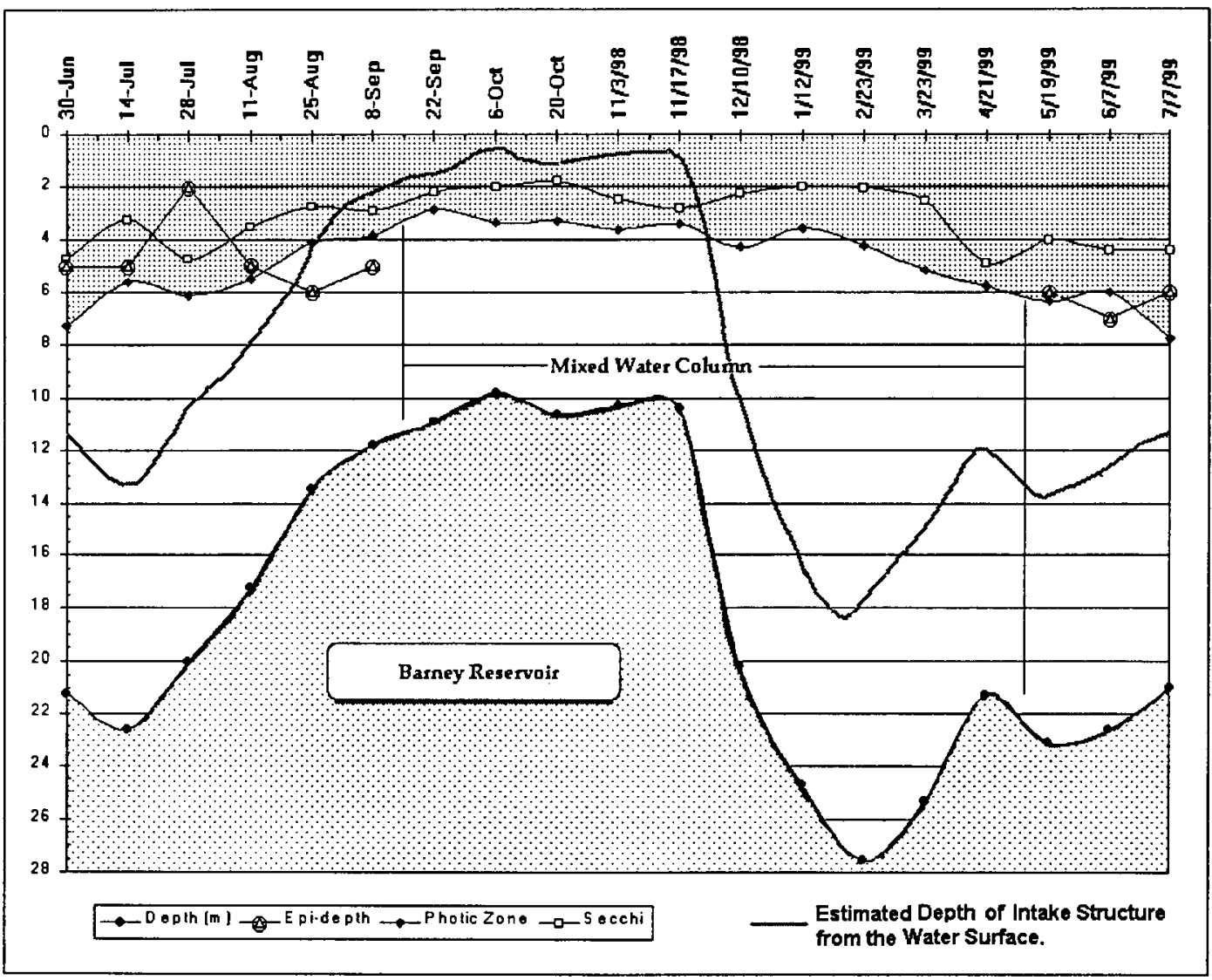

Figure 35. Barney Reservoir. Epilimnion, Secchi and Photic depths. 


\section{Temperature}

From spring to the mid-fall 1998, Barney Reservoir was stratified. At the same time, as the water elevation dropped, the water column began to mix (Figure 35). However, these lower water levels alone do not explain the early mixing of the water column. The general West-to East orientation of the surrounding hills force the westerly winds to increase their velocities by a 'canyon effect' and to transfer some of their energy to the surface water of the reservoir. Since the main axis of reservoir (fetch) is also oriented in the same general direction of the hills the resulting effect is a mixed water column. As a result, from early September 1998 to April 1999 this reservoir had a mixed water column (Figure 36).

The epilimnetic temperature had an average value of $13.9^{\circ} \mathrm{C}$, a high of $26.1^{\circ} \mathrm{C}$ in July 28,1999 , and a low of $5.8^{\circ} \mathrm{C}$ in February 1999 . The time-depth graph of the temperature (Figure 36a) shows the extent of the stratification and the changes in depth at the main sampling station.

The changes in the water elevation of Barney Reservoir and the changes in the depth from the water surface of the intake structure had an impact on the metalimnion and hypolimnion. This impact was in the form of increased hypolimnetic temperatures, which ranged from $9.1^{\circ} \mathrm{C}$ in July 1998 to $18.2^{\circ} \mathrm{C}$ at the end of stratification. 


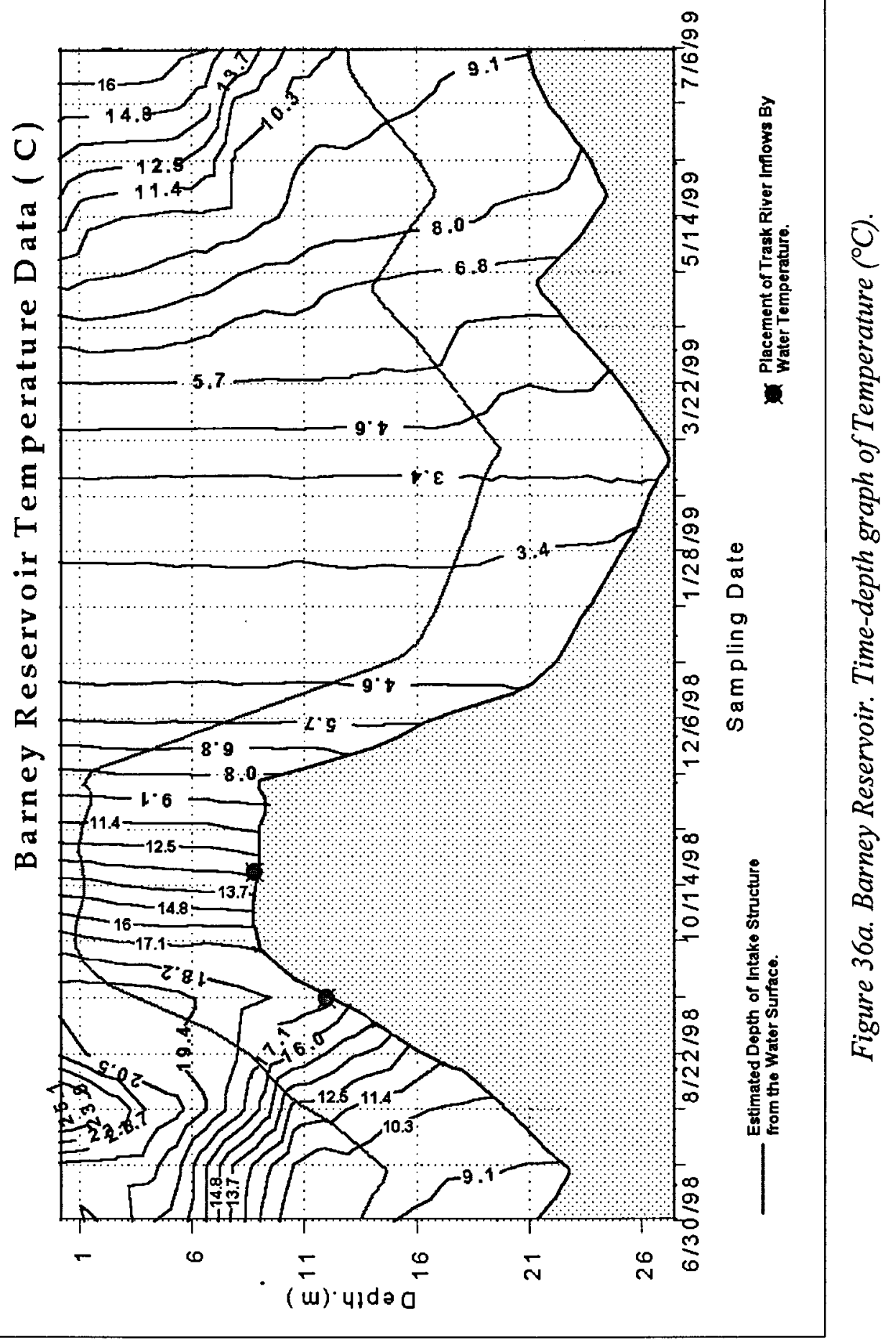




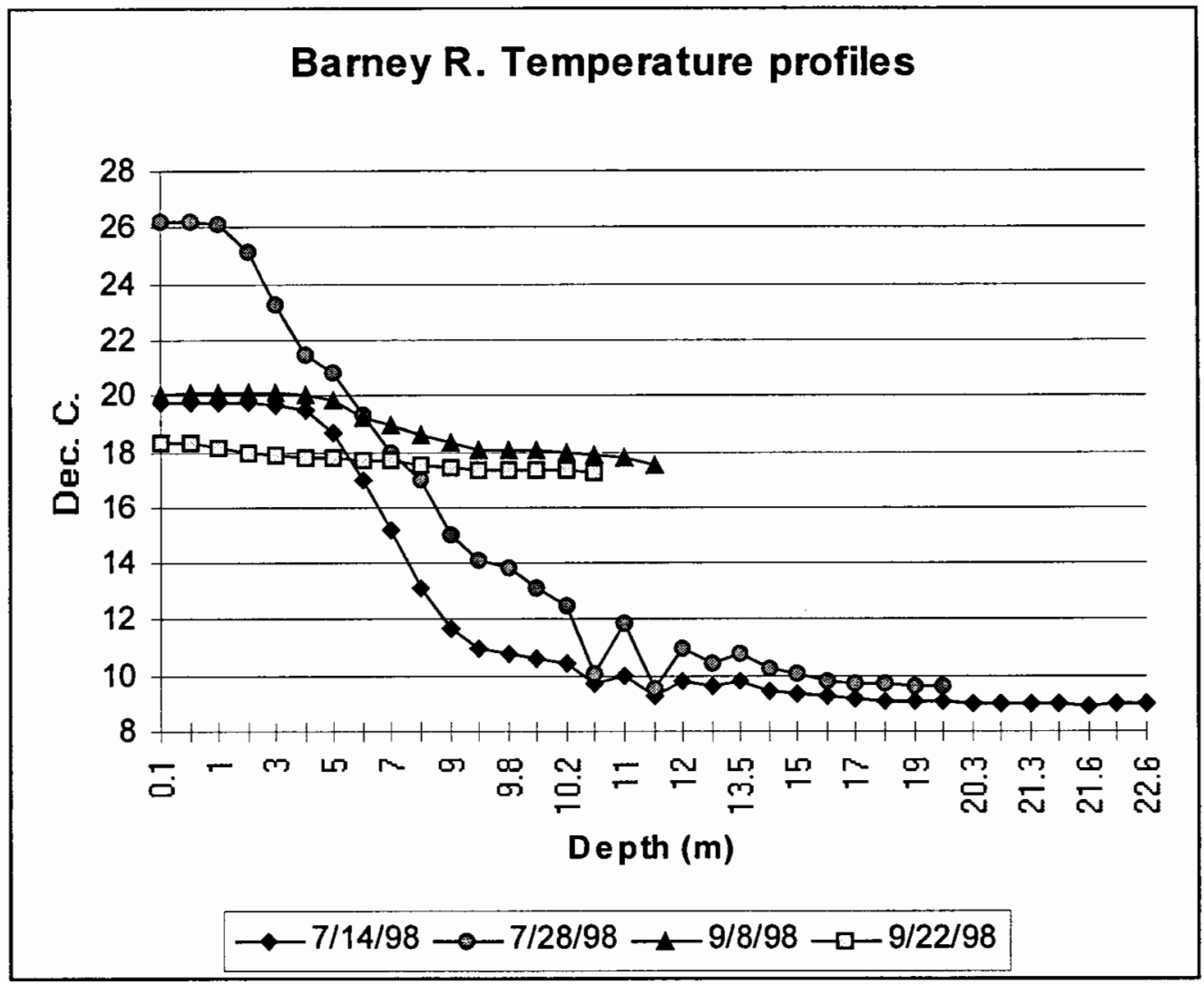

Figure 36b. Barney Reservoir. Temperature profiles from July to September 1998.

\section{Dissolved Oxygen}

The epilimnetic layer was relatively oxygenated throughout the sampling period. Low dissolved oxygen was measured from the end of spring to the end of October 1998, with a minimum reading in August 18, 1998 of $7.35 \mathrm{mg} / \mathrm{L}$. The late fall 1998 and winter-spring 1999 epilimnetic 
dissolved oxygen concentrations were higher with the maximum concentration measured on January 12, 1999 at $13.3 \mathrm{mg} / \mathrm{L}$.

During the stratification of the summer 1998, anoxia conditions formed in the hypolimnion. Some decomposition of organic material could be responsible for this depletion of dissolved oxygen; this explanation is supported in part by the $\mathrm{pH}$ values (Figure 40 ). However, another plausible explanation for the anoxic conditions in the hypolimnion is that increases in water temperatures related to falling water levels, could cause losses of dissolved oxygen to the atmosphere. As the solubility of oxygen depends on water temperature, atmospheric pressure and ionic concentrations, generally at higher water temperatures, the dissolved oxygen saturation values diminish (Wetzel and Likens, 1991).

The profiles of dissolved oxygen appeared less influenced by the changes in the depth from the water surface of the intake structure, as was the case in Hagg Lake. 


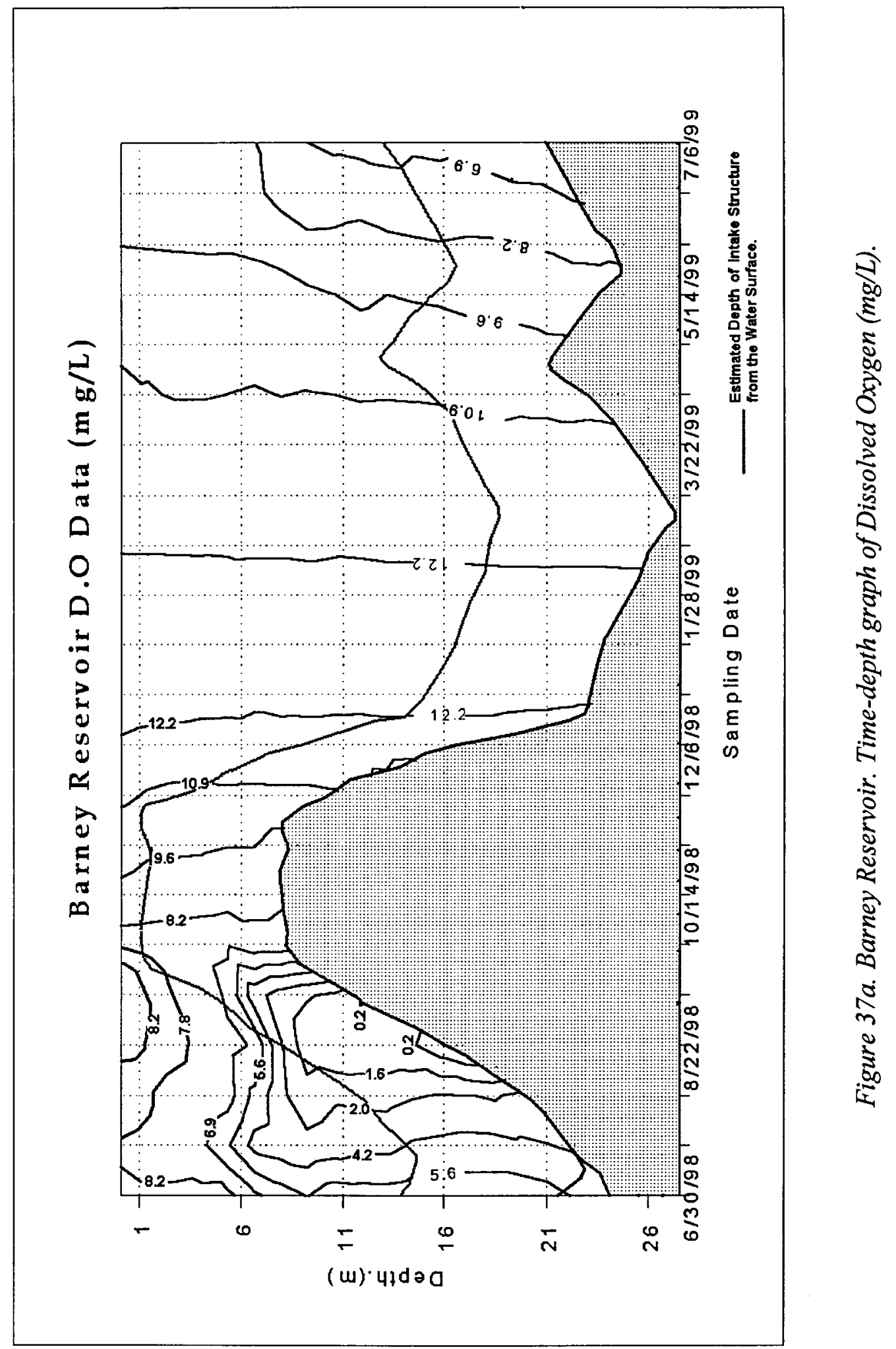




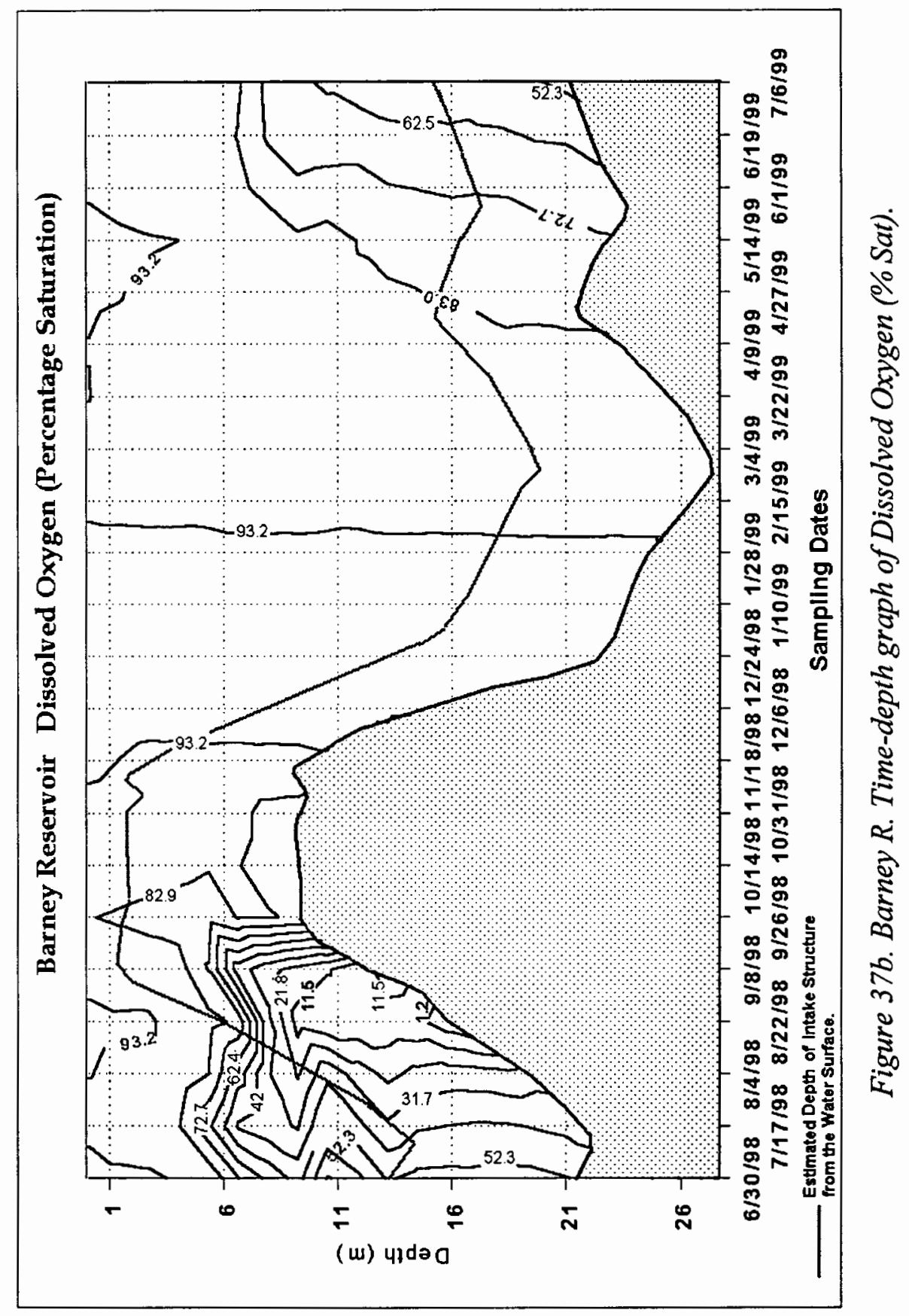




\section{Secchi depth and Irradiance:}

Barney Reservoir average Secchi depth was $3.14 \mathrm{~m}$. The Secchi depth was higher during the spring and early summer of 1998 (average $4 \mathrm{~m}$ ) and lower during fall 1998 and winter 1999 (average 2 m). In 1998 the highest Secchi depth was measured at $4.75 \mathrm{~m}$ on June 30. The 1999 highest Secchi depth was measured in April at $4.9 \mathrm{~m}$. The lowest Secchi depth was measured in October 1998 at 1.75 m (Figure 38). Secchi depth appeared to be more affected by changes in the water levels than by the high inflows caused by the late fall and winter storms. However, high inflows also decreased water transparency (i.e. Secchi depth of $2 \mathrm{~m}$ in February 1999). 


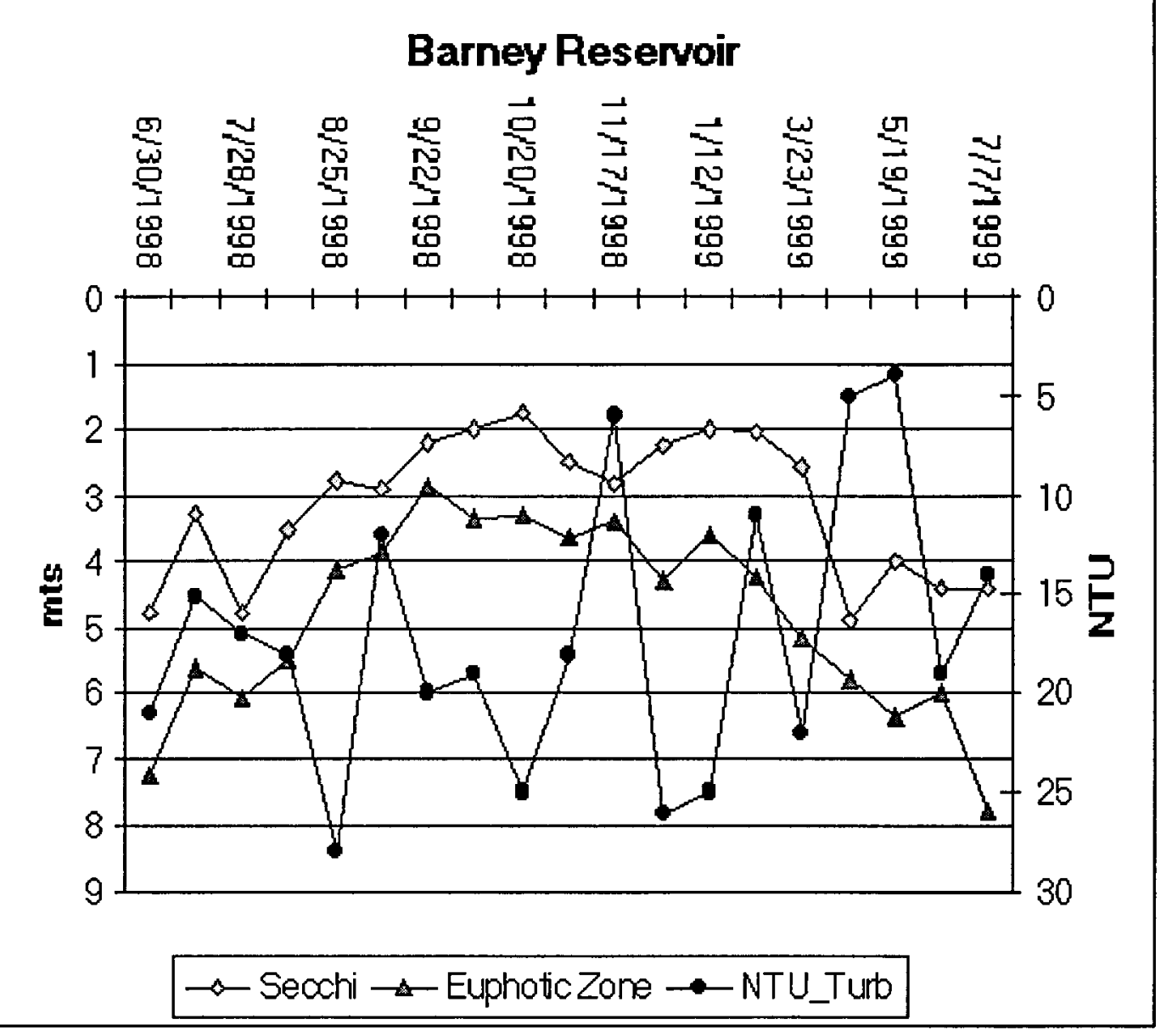

Figure 38. Barney Reservoir. Secchi and Photic depth.

Irradiance ( $\mu$ Einsteins $\mathrm{m}^{-2} \cdot \mathrm{s}^{-1}$ ) was used to calculate the depth of the photic zone (Wetzel, 1991). The pattern that emerged was somewhat similar to the Secchi depth, with the shallowest photic zone occurring in September 1998 at $2.86 \mathrm{~m}$, and the deepest photic zone in June 1998 at $7.25 \mathrm{~m}$ and July 
1999 at $7.76 \mathrm{~m}$. The photic zone was deeper during the spring and early summer of 1998 and the spring of 1999. As with Secchi depth, the depth of the photic zone was influenced by the biovolumes of plankton, the low water levels, the short, unstable stratification period and the greater winter inflows of water.

\section{Turbidity}

Epilimnetic turbidity in Barney Reservoir was relatively low, with a minimum value of 4 NTUs in May 1999 and a maximum value of 28 NTUs in August 1998. Increases in turbidity in Barney Reservoir during the spring and fall of 1998 were related to low water levels, and to increased water inputs during winter 1999. The turbidity throughout the water column during all the sampling dates was relatively homogeneous, except in the sample that coincided with the maximum drop in the water levels (Figure 38). An explanation offered is that as the water levels fell, sediments from the coves and shores were disturbed by the waves and carried back to the pelagic waters. When the water levels ceased to drop, the sediments sank and the turbidity values decreased (Figure 39). The overall relatively low observed turbidity could be the result of a combination of factors such as a smaller watershed with a high percentage covered by vegetation, low human impacts, and many sources of low volume inflows (Table 1, Figure 33). 


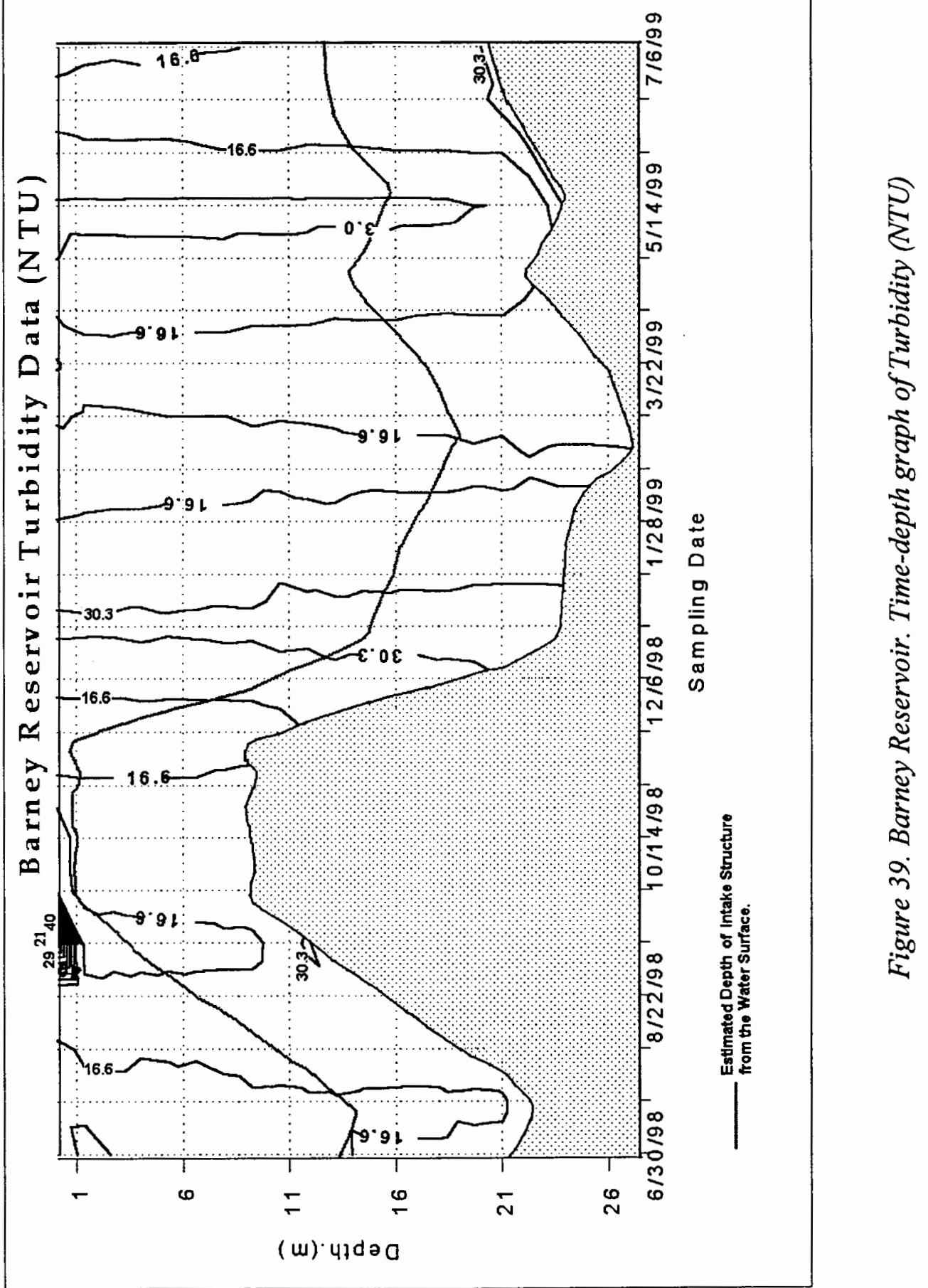




\section{b) Chemical factors}

\section{1. $p H$}

During the period of stratification the epilimnetic $\mathrm{pH}$ was greater than the $\mathrm{pH}$ in the metalimnion and hypolimnion (spring-summer 1998 and spring 1999). The value of the maximum $\mathrm{pH}$ was 7.39 units in July 28,1999 and 7.48 in July 7,1999 . The lowest epilimnetic $\mathrm{pH}$ was measured in March 1999 at 6.68 units. In the anoxic zone, $\mathrm{pH}$ values were measured between 6.3 and 6.8 units. The average epilimnetic $\mathrm{pH}$ was 6.8. The time-depth graph had a structure similar to the temperature graph (Figure 40).

\section{Conductivity and Redox}

The average epilimnetic conductivity was $48.8 \mu \mathrm{S} / \mathrm{cm}$. The average from June to November 1998 was $55.6 \mu \mathrm{S} / \mathrm{cm}$, the December 1998 to April 1999 average was calculated to be $34.9 \mu \mathrm{S} / \mathrm{cm}$ and the May to July 1999 average was of $42.0 \mu \mathrm{S} / \mathrm{cm}$. The observed conductivity values increased at the same time the water levels dropped and vice versa. The summer hypolimnetic conductivity was slightly lower than the summer epilimnetic conductivity. 
Unlike in the case of Hagg Lake the depth of the intake structure from the water surface had no effect on the profiles of conductivity (Figure 41). The epilimnetic redox values $(\mathrm{mV})$ were low during the stratified summer of 1998, and higher when the water column was mixed or the water levels were high. Hypolimnetic redox values in the summer of 1998 were higher and conductivity was lower than the epilimnetic values. When the water column was mixed or the water levels were high, the redox measurements were homogeneous throughout the water column. The epilimnetic low redox values coincided with some increases in the ammonium and nitrate+nitrite nitrogen, as well with the highest epilimnetic and metalimnetic chlorophyll-a measurements (Figure 42 and 44). The dynamic or pattern of the redox values in Barney Reservoir during the period of this study seemed influenced by the elevation of the water levels (depth of the water column), the temperature and the biological activity occurring in the epilimnion, particularly during stratified conditions. 


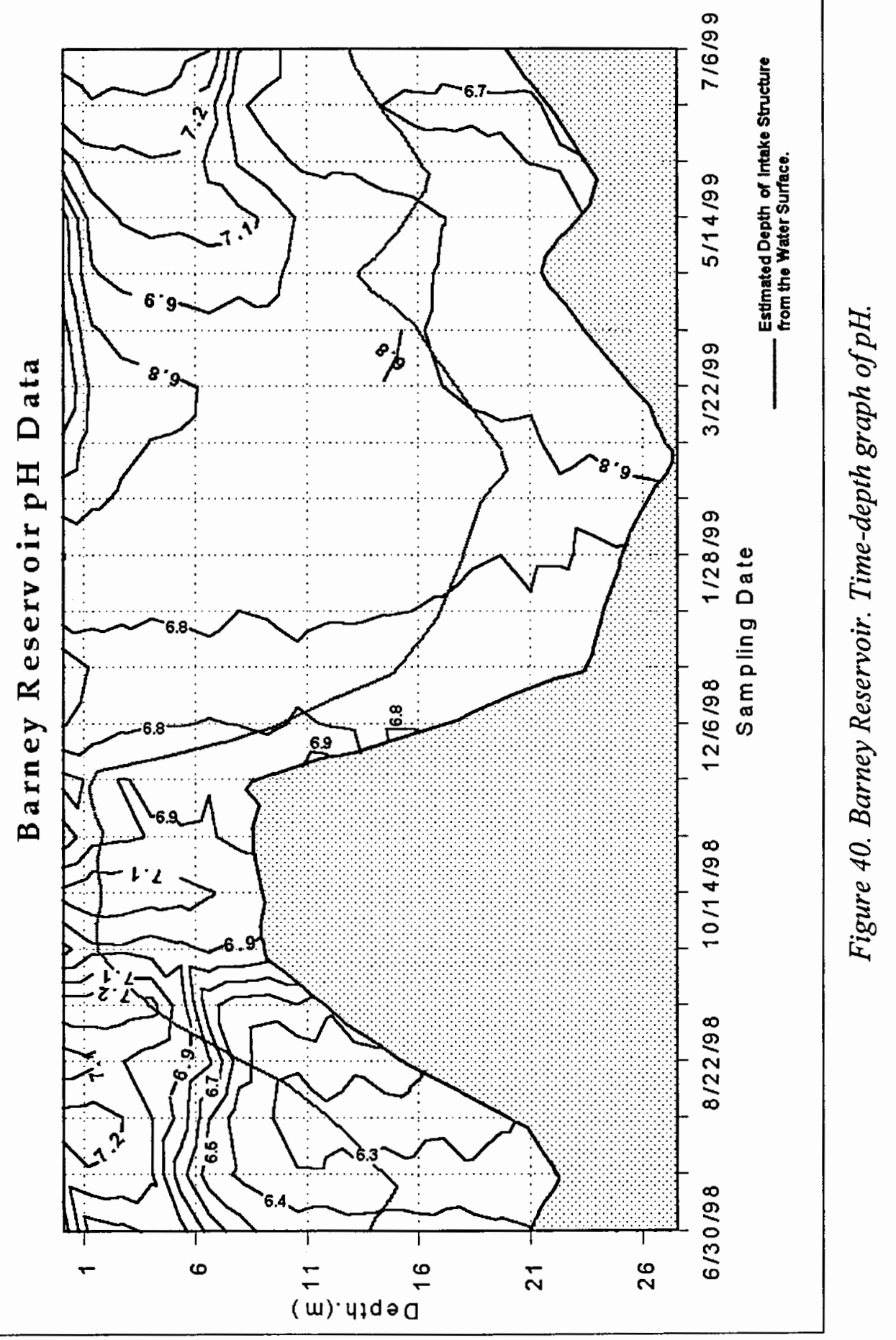




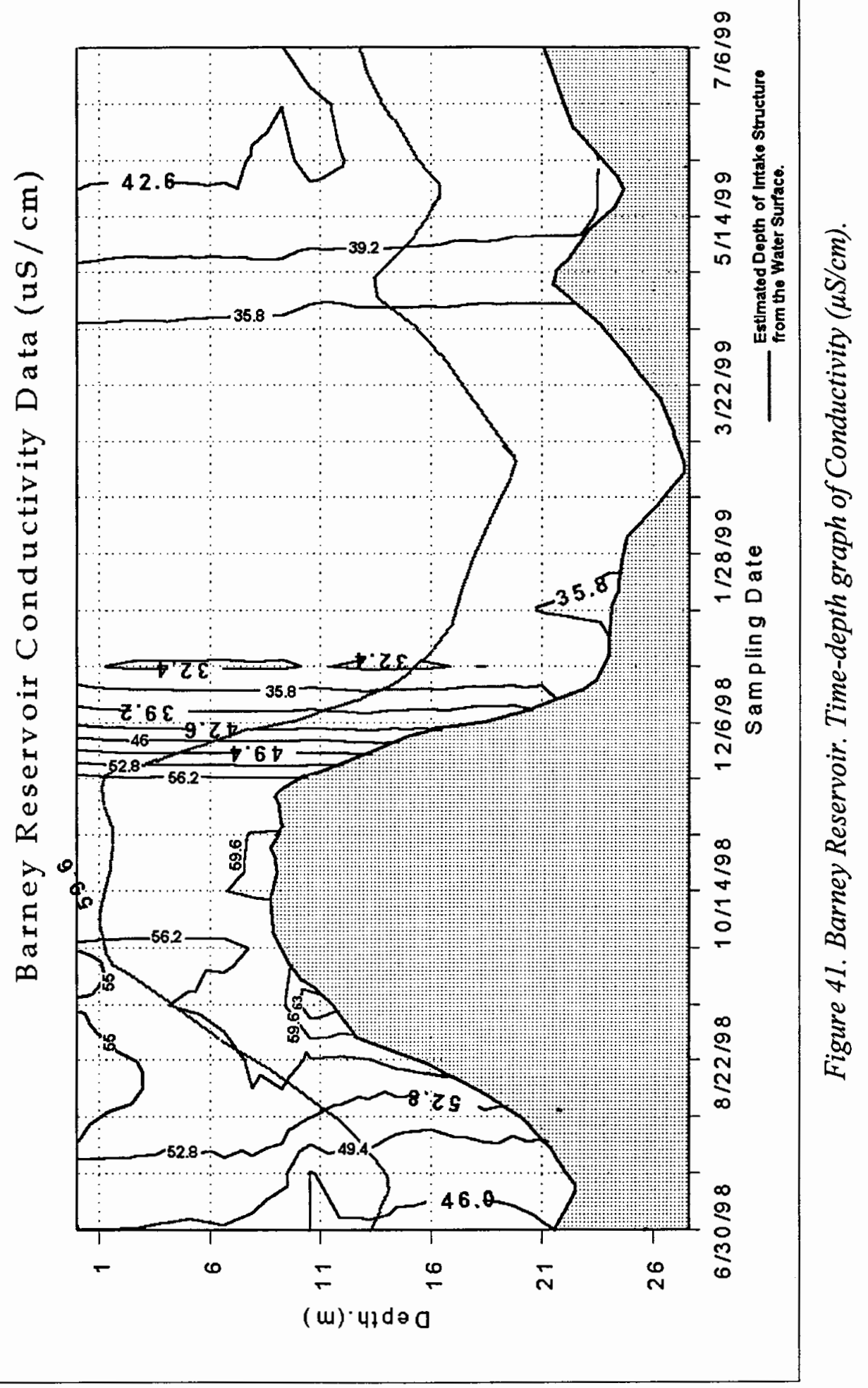




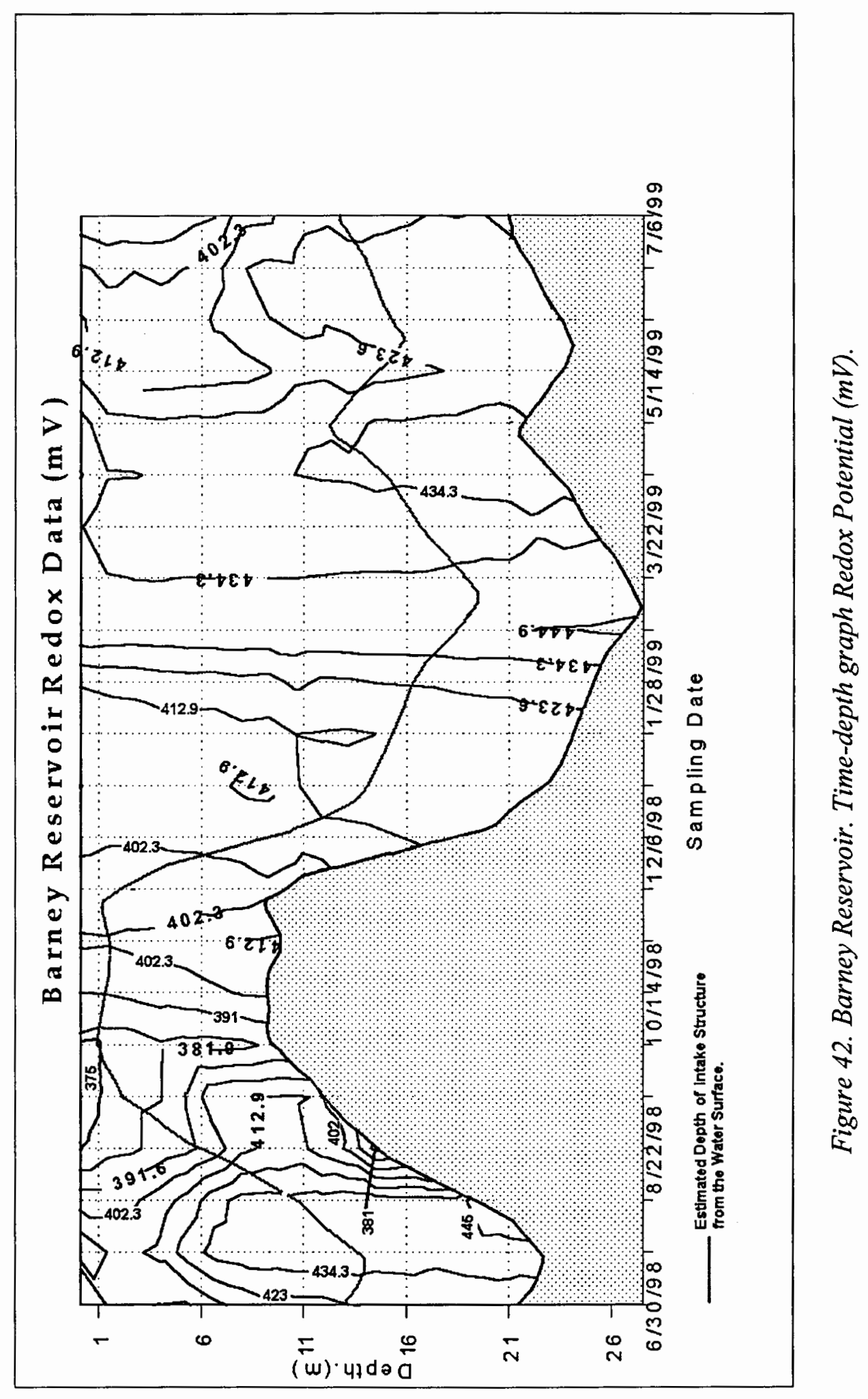




\section{Alkalinity and Dissolved Inorganic Carbon (DIC)}

The average epilimnetic alkalinity (in $\mu$ Equivalent/L) was $441 \mu \mathrm{Eq} / \mathrm{L}$. The average alkalinity from June to November 1998 was $522.7 \mu \mathrm{Eq} / \mathrm{L}$ with a high of $740 \mu \mathrm{Eq} / \mathrm{L}$ occurring in August. From December 1998 to June 1999 the average alkalinity was measured at $328.7 \mu \mathrm{Eq} / \mathrm{L}$ with the lowest measurement on February 23, 1999 at $256.8 \mu \mathrm{Eq} / \mathrm{L}$. From the spring to early fall 1998 alkalinity increased as the water levels decreased, leveling at 500 $\mu \mathrm{Eq} / \mathrm{L}$. At the onset of the late fall storms, the inflows and water levels increased, lowering the $\mathrm{pH}$, the alkalinity and the conductivity (Figure 43a). Generally, the metalimnetic and hypolimnetic alkalinity were equal or lower than the epilimnetic alkalinity. 


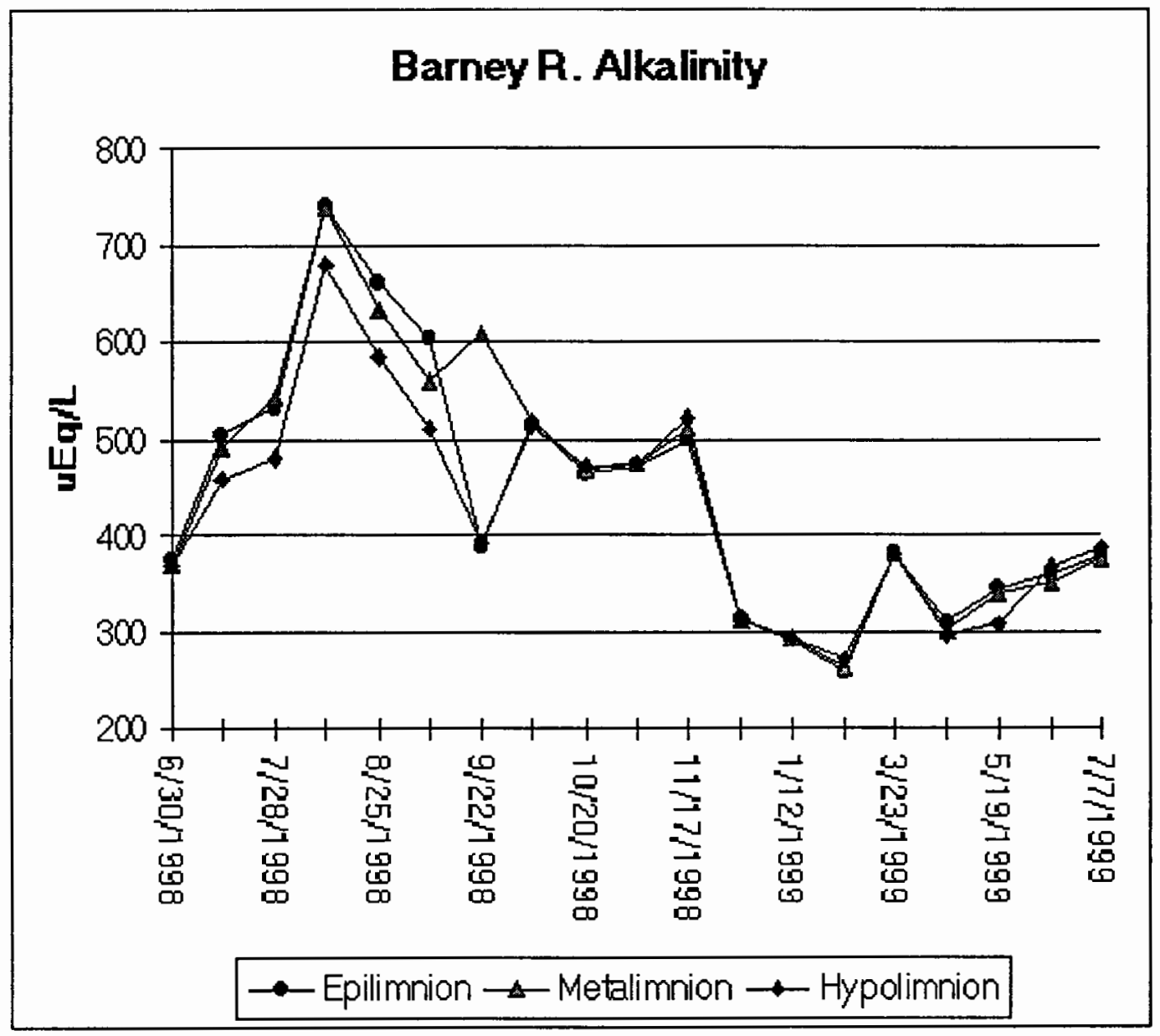

Figure 43a. Barney Reservoir. Alkalinity $(\mu E q / L)$

Differences in dissolved inorganic carbon between the epilimnion, the metalimnion and hypolimnion fluctuated the most when the water levels were dropping; with the epilimnion having the lowest values. A plausible explanation for this phenomenon is that these differences are due to the resuspension of detritus and plant material from the inundated areas (Figure $43 \mathrm{~b})$. Furthermore, increases in water levels and mixing of the water column 
did not cause increases in the DIC. The average DIC was calculated at 0.139 $\mathrm{mg} \mathrm{C} / \mathrm{L}$ and the highest value calculated at $0.21 \mathrm{mg} \mathrm{C} \mathrm{/} \mathrm{L} \mathrm{for} \mathrm{the} \mathrm{sample} \mathrm{of}$ August 11, 1998. The lowest DIC was calculated for the February 1999 sample at $0.105 \mathrm{mg} \mathrm{C} / \mathrm{L}$. The DIC presented here was derived from $\mathrm{pH}$ and alkalinity measurements (Wetzel, 1991).

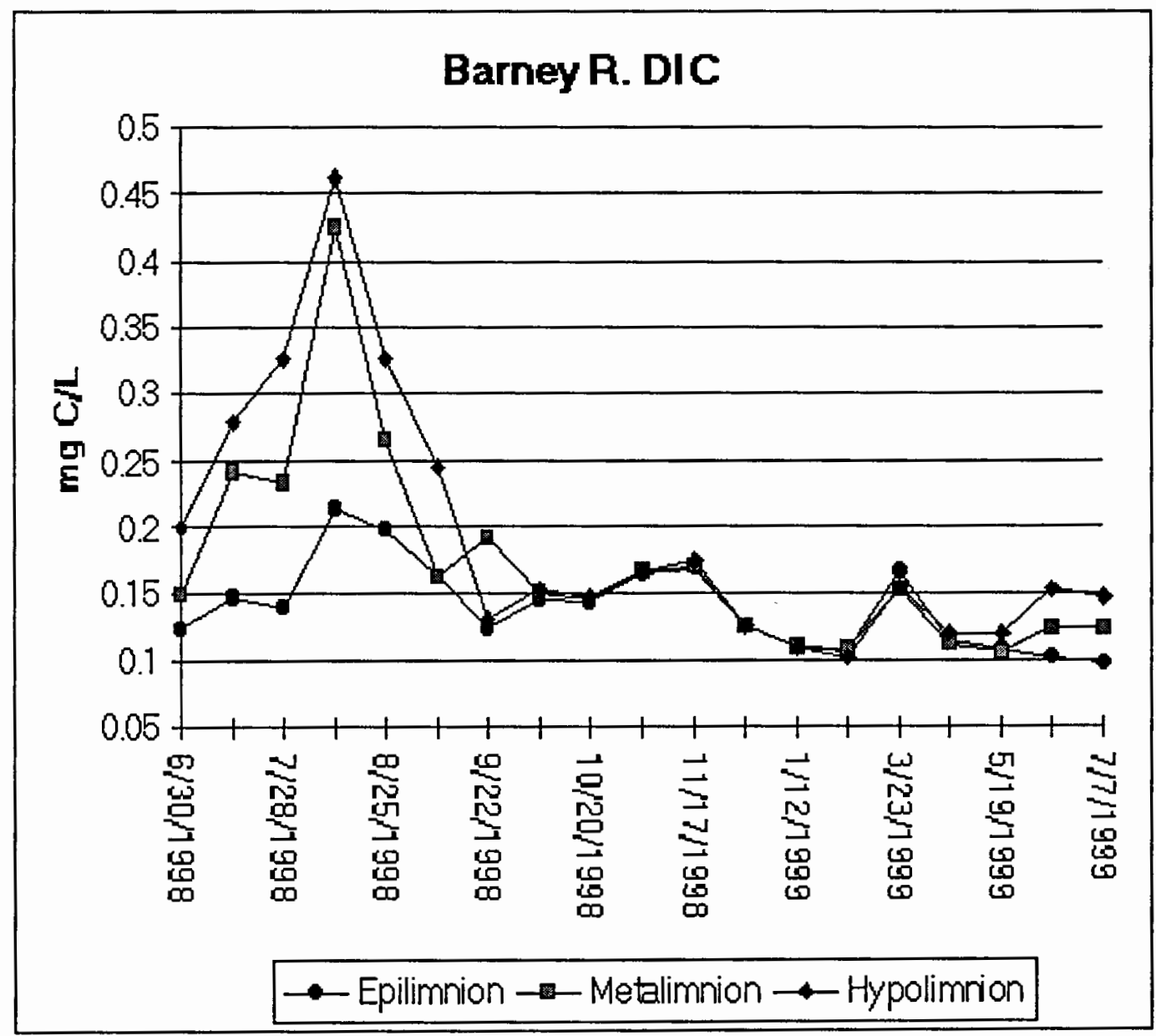

Figure 43b. Barney Reservoir. Dissolved Inorganic Carbon (mg C/L). 


\section{Chlorophyll-a}

The average epilimnetic chlorophyll-a measurement was $2.1 \mu \mathrm{g} / \mathrm{L}$. The highest measurement of chlorophyll-a was $4.53 \mu \mathrm{g} / \mathrm{L}$ made on September 8, 1998, and the lowest was $0.61 \mu \mathrm{g} / \mathrm{L}$ on December 10, 1998. The increases in chlorophyll-a did not correlate with a dominant species. The only observable relationships between increasing chlorophyll-a and phytoplankton was that all the species contributed to the chlorophyll-a readings particularly Cryptomonas sp. By biovolumes, Dinobryon sertularia was the dominant species, however their contribution to chlorophyll-a measurements was not as proportional. For example, in May 1999 the biovolumes of Dinobryon sertularia corresponded to more than $70 \%$ of the total biovolumes but the epilimnetic chlorophyll-a was only measured at 2.98 $\mu \mathrm{g} / \mathrm{L}$ (Figure 44). Metalimnetic chlorophyll-a was generally lower than epilimnetic chlorophyll-a, except in September 8, 1998 when the metalimnetic chlorophyll a was $9.12 \mu \mathrm{g} / \mathrm{L}$.

From June to September 1998 chlorophyll-a increased at the same time water levels decreased and water temperature increased. Once stratification was lost, chlorophyll-a values from October to November 1998 were between 2.67 and $3.06 \mu \mathrm{g} / \mathrm{L}$. Cold temperatures increases in the water levels, and low light condition caused a decrease in chlorophyll-a during the period of 
December 1998 to March 1999. Chlorophyll-a reached a new high in May 1999 (Figure 45).

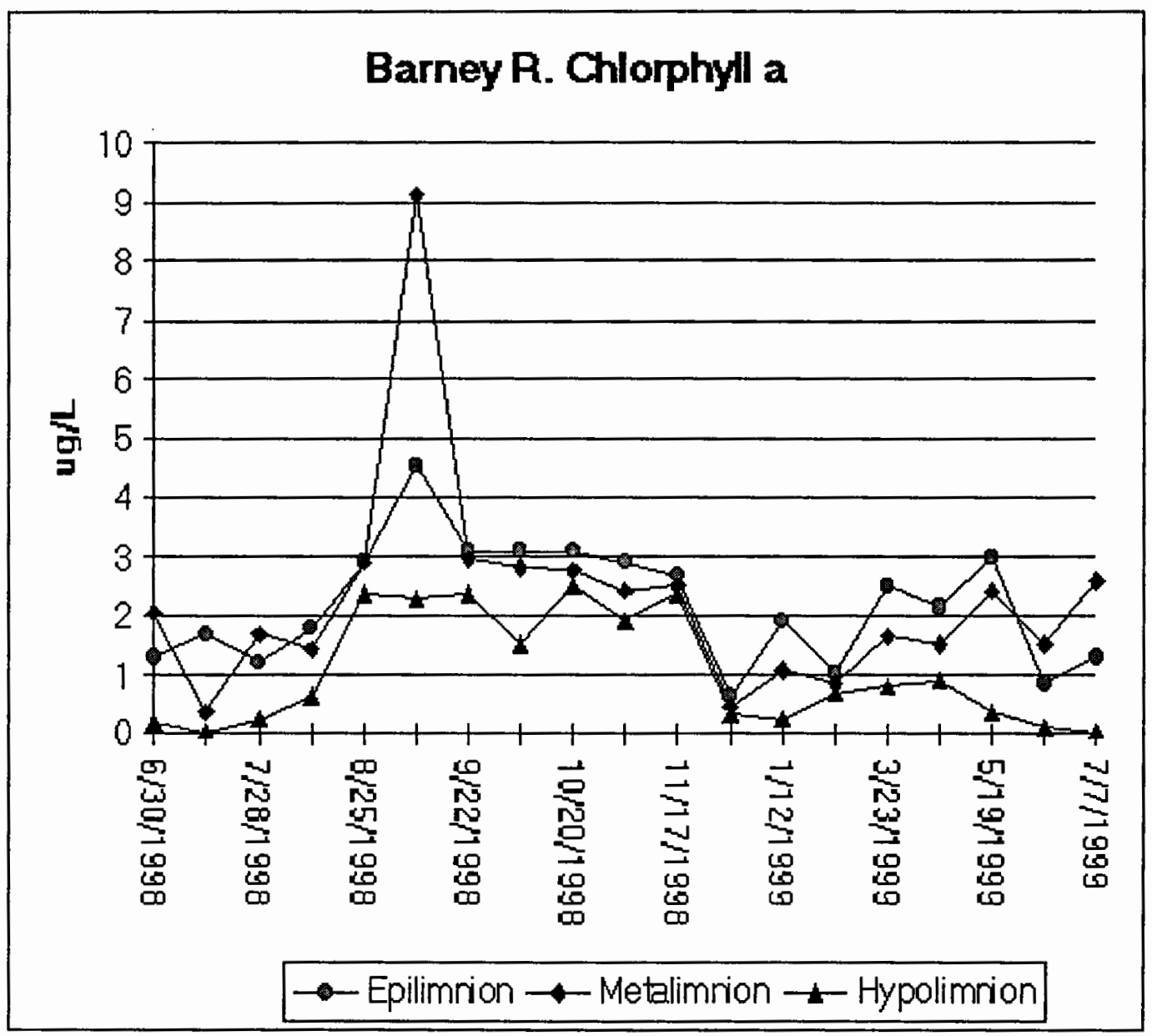

Figure 44. Barney Reservoir. Chlorophyll-a $(\mu \mathrm{g} / \mathrm{L})$.

\section{Total Nitrogen, Nitrate + Nitrite and Ammonia Nitrogen}

From June to November 3, 1998 the total nitrogen measurements were less than $200 \mu \mathrm{g}$ N/L. In November 17, 1998 a sharp increase in total nitrogen was detected. The explanations offered for this increase are: a) that some of 
these nutrients could have arrived in the inflows that initiated a the rise in water levels (Figure 34a), b) and that these increases in water levels coupled with mixing in the water column and the re-suspension of plant debris from the newly inundated areas could have distributed throughout the reservoir nitrogen rich matter.

From December 1998 to February 1999 nitrogen levels were low. In March-April another rise in concentration occurred, followed by a decrease of total nitrogen concentration (Figure 45). The average total nitrogen concentrations were $161 \mu \mathrm{g} \mathrm{N} / \mathrm{L}$ with a maximum concentration of $1249.7 \mu \mathrm{g}$ N/L.

Average epilimnetic nitrate+nitrite concentrations were was $43.5 \mu \mathrm{g}$ $\mathrm{N} / \mathrm{L}$ with a few instances when the concentration was below detectable limits. A maximum concentration of $174 \mu \mathrm{g}$ N/L occurred in December 1998. From July to August 11,1998, the nitrate+nitrite concentrations were low; decreases in epilimnetic redox were accompanied by a small increases in nitrate+nitrite followed by a decrease. The loss of stratification and onset of the mixing period could explain increases in nitrate+nitrite concentration that reached a maximum value of $174.9 \mu \mathrm{g} \mathrm{N} / \mathrm{L}$ in December 1998. Winter inflows did not increase the $\mathrm{NO}_{2}+\mathrm{NO}_{3}$ concentrations, and by May 1999 the $\mathrm{NO}_{2}+\mathrm{NO}_{3}$ concentrations were low again (Figure 46). 


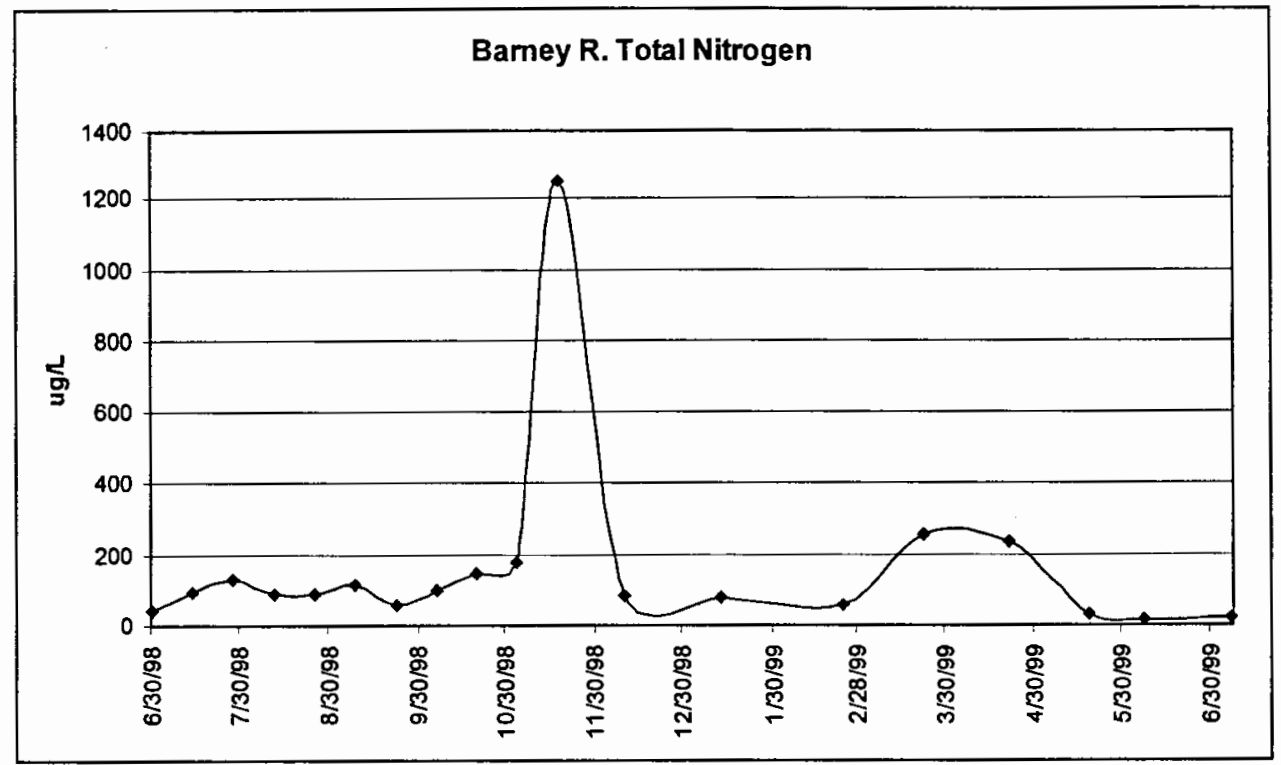

Figure 45. Barney Reservoir. Total Nitrogen $(\mu g N / L)$.

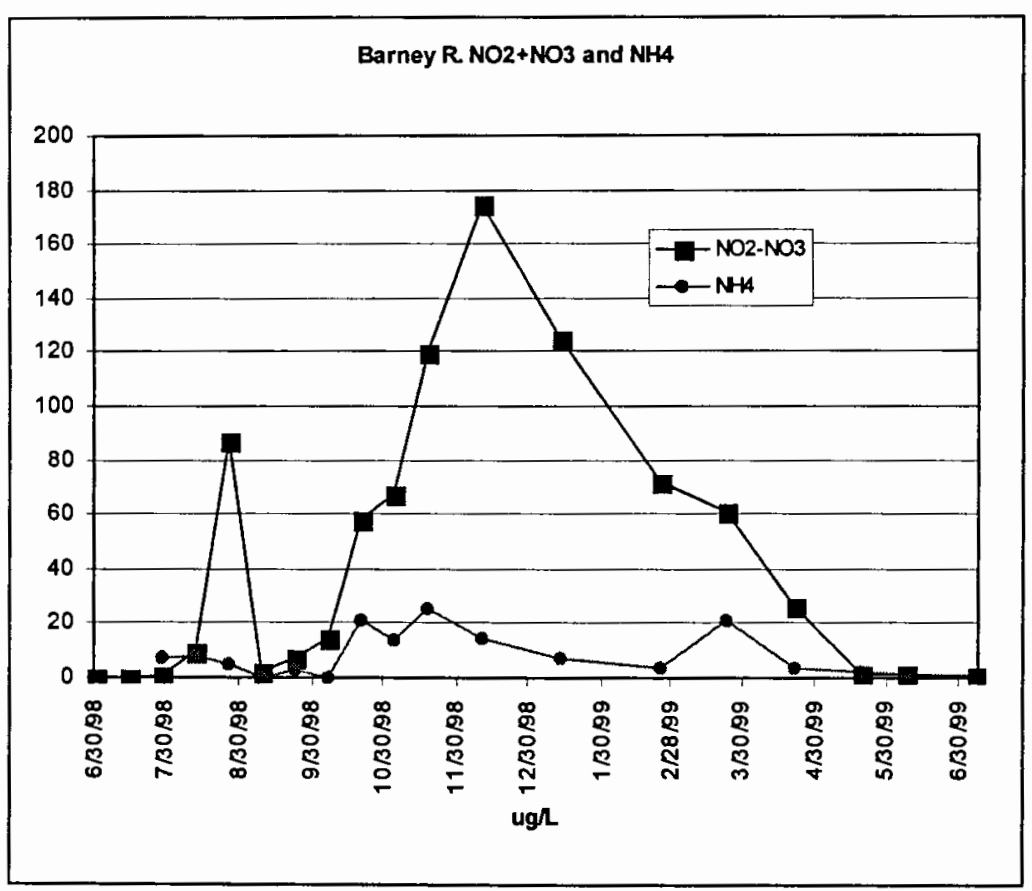

Figure 46. Barney Reservoir. Nitrate+nitrite and Ammonium ( $\mu \mathrm{g} N / L)$. 
Epilimnetic ammonium nitrogen concentrations were low, with an average of $8 \mu \mathrm{g} \mathrm{N} / \mathrm{L}$ and a maximum value of $25.23 \mu \mathrm{g} / \mathrm{L}$ in November 1998. No particular pattern emerged from the plot of the measured ammonium nitrogen concentrations, and the only statement that can be made is that it increased slightly during the period of mixing from September 1998 to April 1999 (Figure 46).

\section{Total Phosphorous and Soluble Reactive Phosphorous}

The average concentration of total phosphorous was $11.2 \mu \mathrm{g} / \mathrm{L}$ with a high concentration of $23.7 \mu \mathrm{g} \mathrm{P} / \mathrm{L}$ in September 11, 1998, and a low of 2.8 $\mu \mathrm{g}$ P/L in May 1999. Total phosphorus concentrations were generally low and did not follow a discernible pattern or show a particular relationship with other variables. The average total phosphorous concentrations during the period of mixed water column (September 1998 - April 1999) were 12.4 $\mu \mathrm{g} P / \mathrm{L}$.

Concentrations of SRP in Barney Reservoir had an average of $2.4 \mu \mathrm{g}$ $\mathrm{P} / \mathrm{L}$, a value that according to Reynolds (1984) describes a phosphorous limited phytoplankton community. The maximum SRP concentration was 5.1 $\mu \mathrm{g}$ P/L measured in September 1998, the minimum SRP concentration measured was of $1.32 \mu \mathrm{g}$ P/L in July 1998. These low SRP and Total 
Phosphorous concentrations can be one of the reasons why the chlorophyll-a and phytoplankton biovolumes are relatively low (Figure 47).

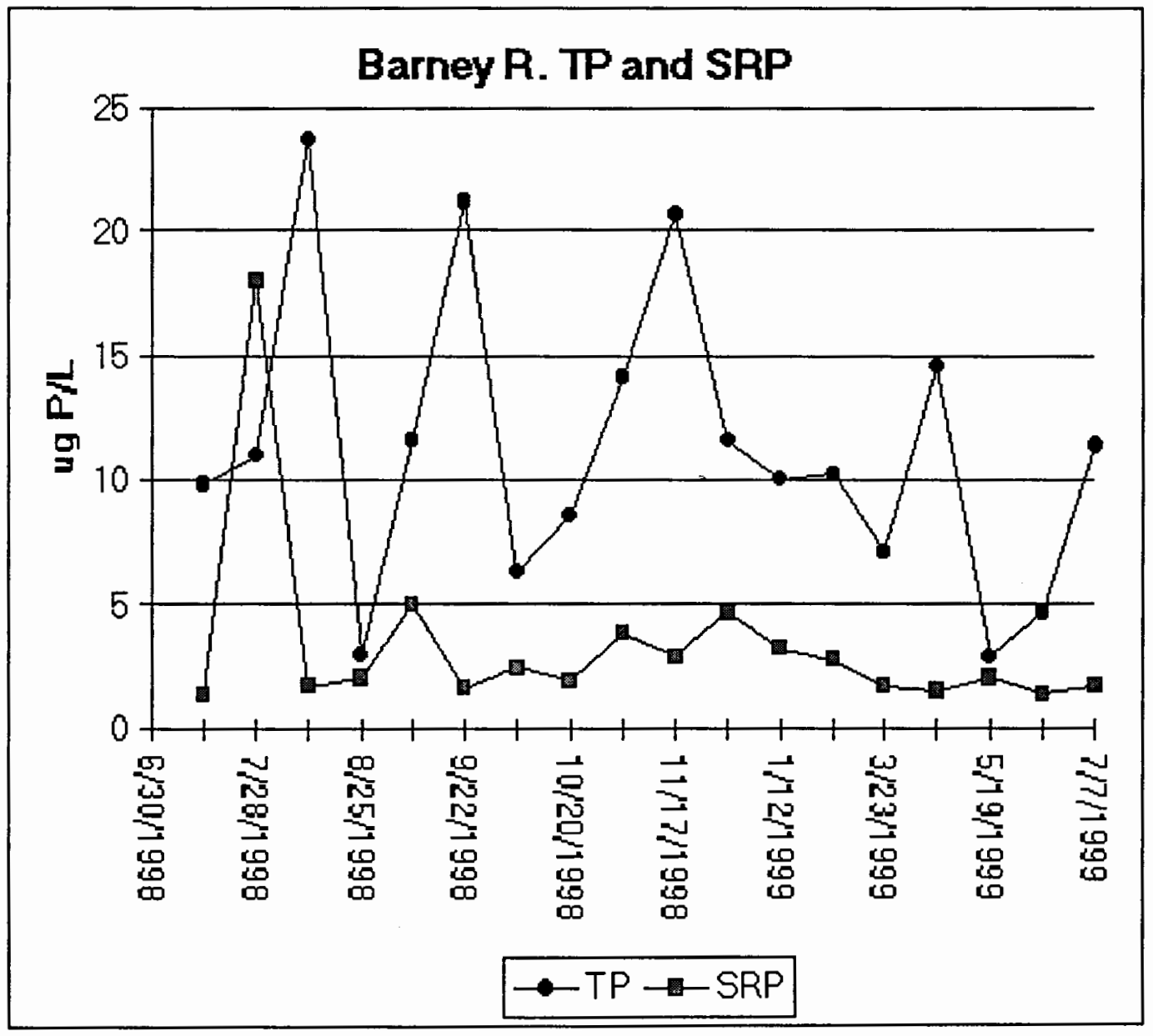

Figure 47. Barney Reservoir. TP and SRP ( $\mu g$ P/L). 


\section{Dissolved Silica}

The silicon was measured as dissolved silica $\left(\mathrm{SiO}_{2}\right)$. The average concentration during the study period was $12.4 \mathrm{mg} \mathrm{SiO}_{2} / \mathrm{L}$, with a maximum value of $16.43 \mathrm{mg} \mathrm{SiO}_{2} / \mathrm{L}$ on September 8,1998 and a minimum value of 4.32 on October 6, 1998. On October 6, the concentrations of dissolved silica dropped from $14.8 \mathrm{mg} \mathrm{SiO}_{2} / \mathrm{L}(9 / 22 / 1998)$ to $4.32 \mathrm{mg} \mathrm{SiO}_{2} / \mathrm{L}$. At the same time that the silica concentration dropped, the water depth reached its lowest value $(9.8 \mathrm{~m})$ and the biovolumes of the Bacillariophycea (diatoms) reached its peak (Figure 48). Once this short burst of diatom growth passed, silica concentrations increased again.

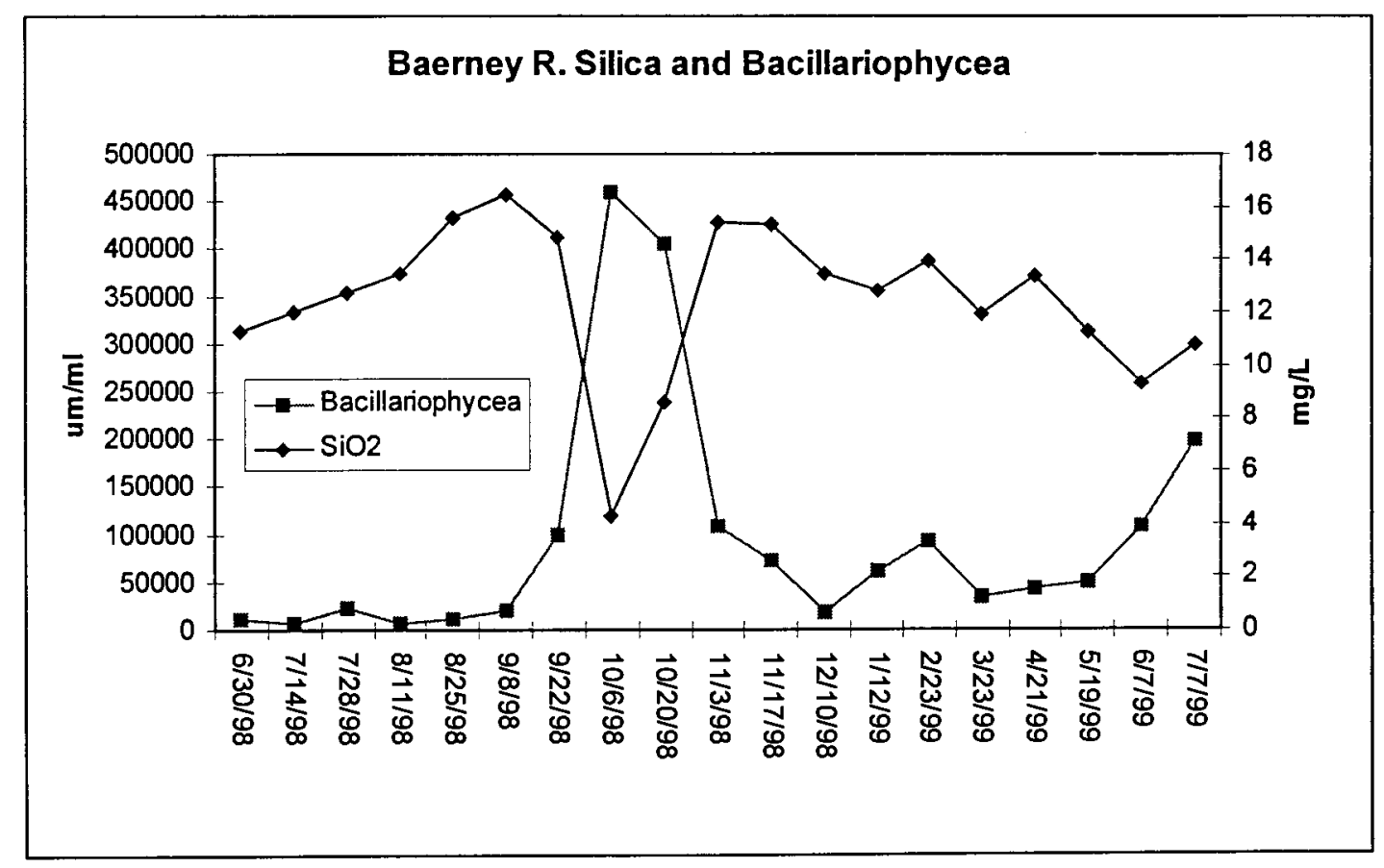

Figure 48. Barney Reservoir. Silica (mg/L). 


\section{Major Dissolved Cations: $\mathrm{Na}, \mathrm{K}, \mathrm{Mg}$ and $\mathrm{Ca}$}

The concentrations of $\mathrm{Na}, \mathrm{Ca}$ and $\mathrm{Mg}$ were between 1.5 to $6.6 \mathrm{mg} / \mathrm{L}$ whereas the concentrations of $\mathrm{K}$ never rose above $0.46 \mathrm{mg} \mathrm{K} / \mathrm{L}$.

Ca measurements were higher during the period of diminishing water volumes and low water levels (June-November 1998). Inputs of water and increases in water levels appeared to 'diluted' the Ca concentrations. At the end of the winter 1999, Ca concentrations began to rise again (Figure 49a). The average Ca concentration was $2.9 \mathrm{mg}$. Ca/L with a high of $4.98 \mathrm{mg}$. $\mathrm{Ca} / \mathrm{L}$ in July 28,1998 , and a low concentration of $1.6 \mathrm{mg} \mathrm{Ca} / \mathrm{L}$ in February 1999.

Dissolved Na concentrations were also higher during the decreasing water elevation and the period of constant low water levels. With increases in water volumes and elevation, Dissolved $\mathrm{Na}$ concentrations increased somewhat, but by mid-winter the concentrations of $\mathrm{Na}$ were at its lowest. By the end of the winter 1999, sodium concentrations began to rise again. The average concentration of $\mathrm{Na}$ was $4.4 \mathrm{mg} \mathrm{Na} / \mathrm{L}$ with a maximum of $6.5 \mathrm{mg}$ $\mathrm{Na} / \mathrm{L}$ in October 6,1998, and a minimum concentration of $2.4 \mathrm{mg} \mathrm{Na} / \mathrm{L}$ in February 1999 (Figure 49). 


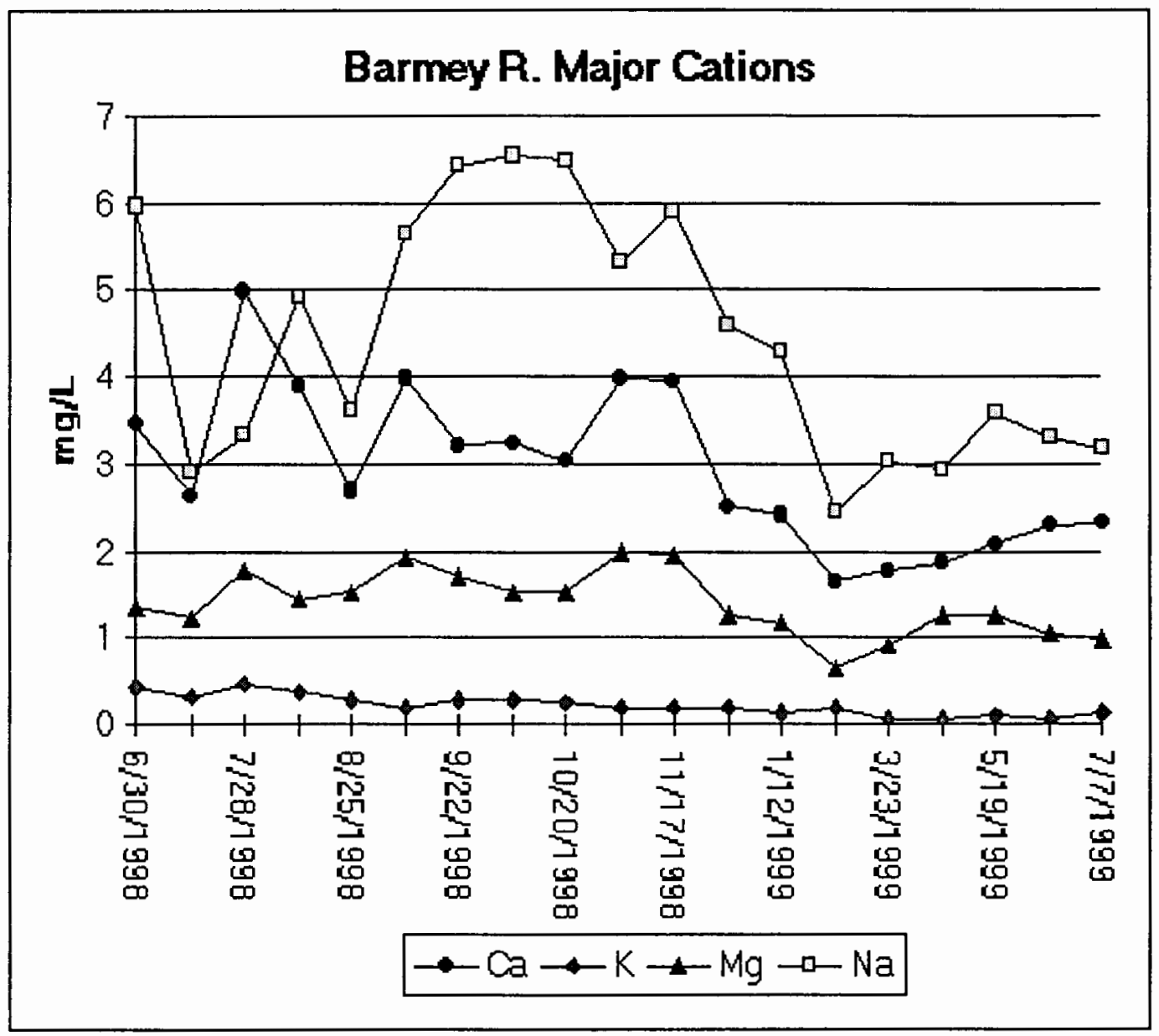

Figure 49. Barney Reservoir. Cations: $\mathrm{Na}, \mathrm{Ca}, \mathrm{Mg}$ and $\mathrm{K}$ (in $\mathrm{mg} / \mathrm{L}$ ).

Dissolved $\mathrm{Mg}$ had relatively higher concentrations during the period of decreasing water elevation and the period of constantly low water levels (June-November 1998). The result of the increased water volumes was a decrease in $\mathrm{Mg}$ concentrations. By the end of the winter 1999, Mg concentrations began to rise (Figure 49). The average $\mathrm{Mg}$ concentrations were $1.39 \mathrm{mg} \mathrm{Mg} / \mathrm{L}$, with a maximum concentration of $1.97 \mathrm{mg} \mathrm{Mg} / \mathrm{L}$ in 
November 1998, and a minimum concentration of $0.64 \mathrm{mg} \mathrm{Mg} / \mathrm{L}$ in February 1999.

The concentrations of dissolved $\mathrm{K}$ were higher when water elevation was decreasing and when the water elevation was constant although low (June-November 1998). The result of the increased water volumes was a further decrease in potassium concentrations. After the winter 1999 the concentrations of potassium began to rise (Figure 49 ). The average $\mathrm{K}$ concentration was $0.21 \mathrm{mg} \mathrm{K} / \mathrm{L}$, with a maximum concentration of $0.46 \mathrm{mg}$ $\mathrm{K} / \mathrm{L}$ in July 28,1998 , and a minimum concentration of $0.06 \mathrm{mg} \mathrm{K} / \mathrm{L}$ in April 1999.

Low inflows and decreased water levels from June to November 1998 appeared to increase the concentration of cations present in Barney Reservoir. High precipitation and inflows associated with late fall 1998 and winter 1999 increased the volume of the reservoir and 'diluted' the concentrations of cations. On the other hand, epilimnetic conductivity had a similar pattern, with high conductivity during low water volumes and vice versa. The major anions (Chloride and Sulfate) were not measured consistently during this study, and only one sample from Barney Reservoir is reported here (Figure 24b). The dissolved chloride concentration measurement was higher than the chloride measurements for Hagg Lake, 
and the dissolved sulfate concentrations were lower than the Hagg Lake measurements.

\section{Trophic State Indices}

TSI for Barney Reservoir was calculated using the formulae proposed by Carlson (1977). Figure 50 portrays these variations for TSI for Secchi depth, Chlorophyll-a and Total Phosphorous.

The calculated TSI for Secchi depth had an average of 44.27 units, with the highest values occurring October 20,1998 at 51.9, during the period of mixed water column (Late September, 1998 to April 1999). Decreases occurred before and after the mixing period. The effects of increased water volumes and elevations on the TSI for Secchi depth were minimal. This occurred probably because there was little human activity in the watershed and most of the suspended materials came from the shores of the reservoir and the newly inundated areas.

The calculated TSI for chlorophyll-a had an average of 37.06, with the highest value calculated for September 8, 1998 at 45.4 units, and the lowest on December 1999 at 25.7 units. The pattern of the TSI for Chlorophyll-a was identical to the actual chlorophyll-a measurements.

The calculated TSI for total phosphorus had an average of 36.8 units. Low TSI-TP occurred on September 22, 1998 and May 1999 (19.7 and 19.05 units respectively), outside of the period of mixing. Also, there was some 
increase during the time of low water elevations and some decrease when the water volume increased. The pattern that emerged indicates a strong relationship between mixing, water depth and re-suspension of phosphorus from the sediments.

Based on the data, Barney Reservoir is a reservoir with a mesotrophic lacustrine zone, with few occasions when the TSI for chlorophyll-a and total phosphorus reached the oligotrophic range, and two occasions when the TSI for Secchi depth reached the eutrophic range (Tables 9a, 9b). Figure 50 indicates that during winter this reservoir experiences conditions of light limitation.

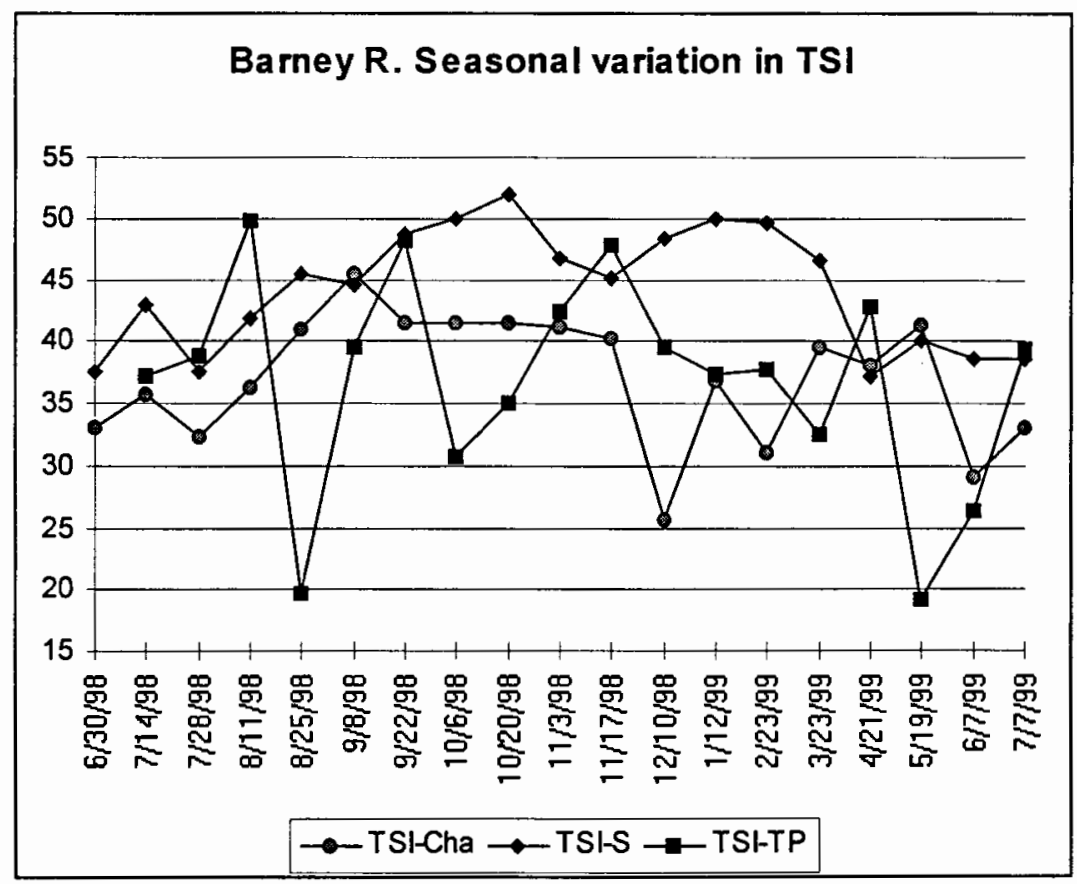

Figure 50. Barney Reservoir. Seasonal Trophic State Indices. 


\section{Nutrient Ratios}

The average value of Barney Reservoir epilimnetic total nitrogen total phosphorous (TN:TP) mass ratios was 14.67 , with a high ratio of 60.5 calculated for November 17, 1998, and a low ratio of 2.2 calculated for July 1999. The three high TN:TP ratios occurred when either total nitrogen increased (Nov. 1998) or total phosphorus decreased. Only in five of the eighteen calculated TN:TP ratios the values were lower than 7 , indicating that some nitrogen limitation occurred (Figure 51). However, total phosphorus was generally low when compared to total nitrogen, the biological activity of the phytoplankton was also low (chlorophyll-a), therefore the information contained in the TN:TP is more difficult to assess without first analyzing the individual nutrient concentration measurements. The effects on the nutrient concentrations of increased flows and water volumes were minimal, particularly if compared with the effects of increased flows on nutrient concentrations in Hagg Lake

The average dissolved silica - total phosphorus (Si:TP) mass ratio was 1486.2 units. The highest Si:TP ratios were calculated at 5267.2 in September 22, 1998, and at 4007 in May 1999. These two highs occurred outside the period of the mixed water column. The average Si:TP during the period of mixing was 1063.7 or 485 units lower than the average for the study period, and 4203.5 units lower than the maximum Si:TP ratios. High water inflows 
did not seem to increases in the Si:TP ratios. In this reservoir, dissolved silica did not appeared be a biologically limiting nutrient. The lowest Si:TP ratio was calculated to 567.1 units $(8 / 18 / 1998)$. The highest Bacillariophycea biovolumes occurred October 6, 1998 when dissolved silica was measured at its lowest (4.32 mg/L) and the calculated Si:TP ratio was 688.9 (Figure 51).

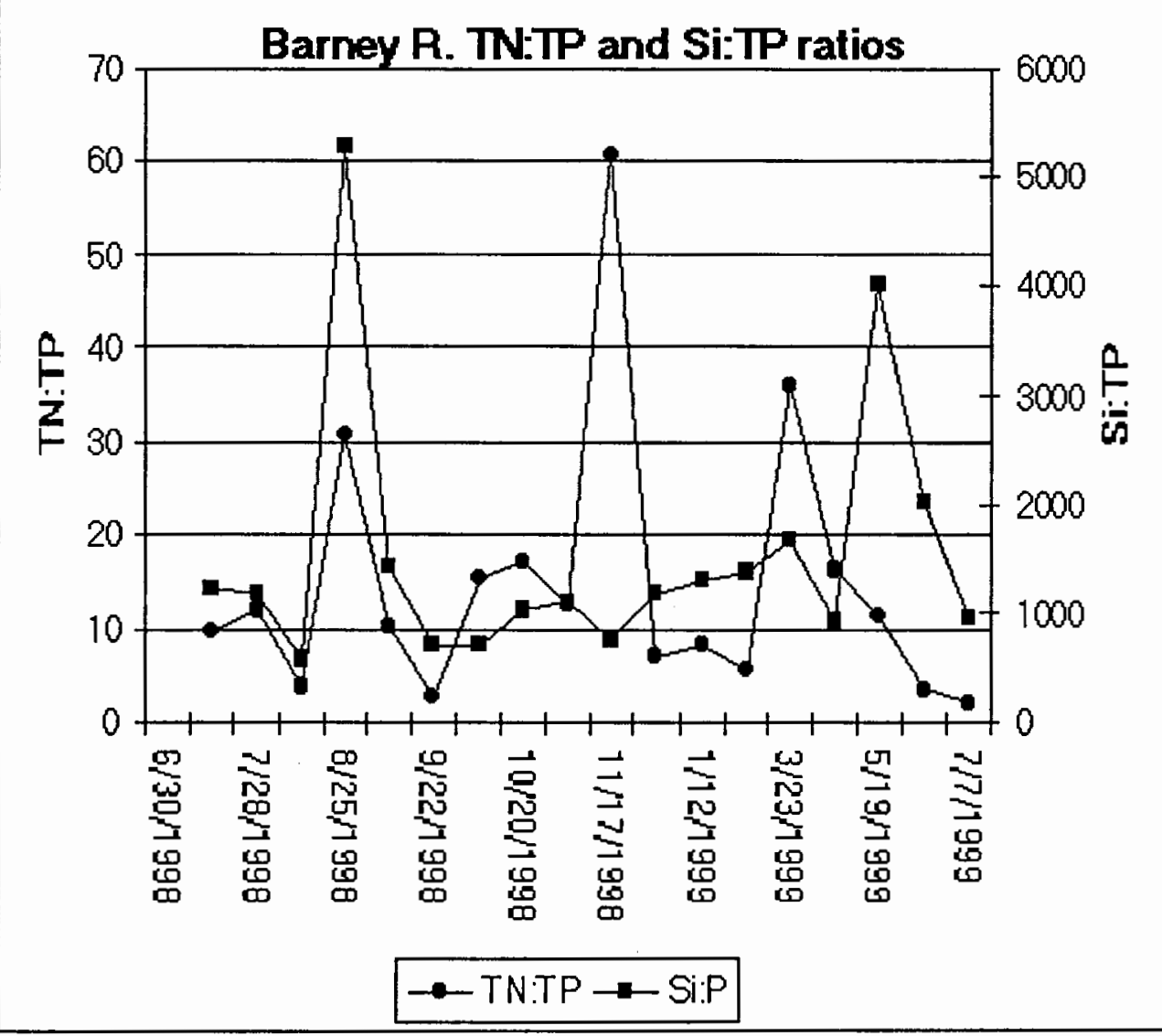

Figure 51. Barney Reservoir. TN:TP and Si:TP Nutrient Ratios. 


\section{c) Biological factors}

\section{Phytoplankton:}

During this period of this study 11 species dominated the measured total biovolumes $(96.1 \%)$. However, limited phosphorus availability and unstable physical conditions in the lacustrine zone of Barney Reservoir could have interfered with the development of a biologically active phytoplankton community, as measured by the concentrations of chlorophyll-a. Whenever peaks in the chlorophyll-a measurements occurred, the biovolumes of Dinobryon sertularia and Cryptomonas sp. were the most dominant. Of the 11 species, five were colonial species and six were not (Figure 52).

Chrysophytes (Dinobryon sp.) dominated the total biovolumes, followed by cryptophytes (Cryptomonas sp.), chlorphyceas (Oocystis borgei, Chlamydomonas sp.) and bacillariophyceas. Euglenophytas and Cyanophytes were also represented in low biovolumes during the period of low water elevation. Dinoflagelates were present throughout the sampling period as well (Table 6). 


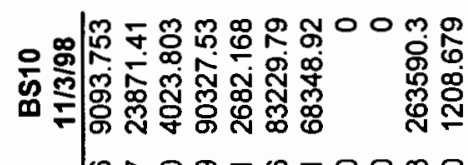

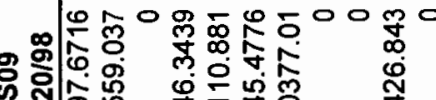

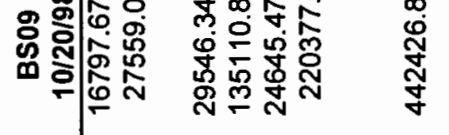

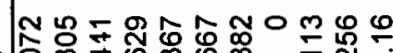

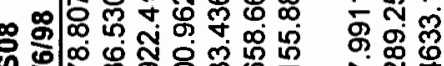

ర్ㅇㅎㅇ

业

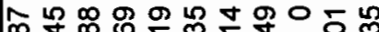

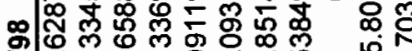

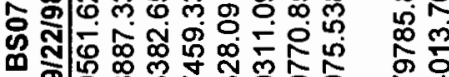

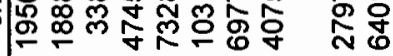

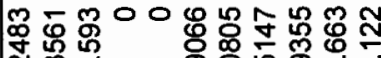

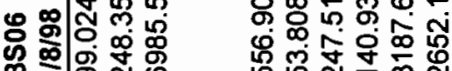

फั

L 10 ON-OH

\%

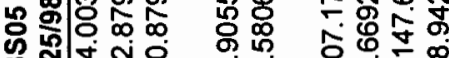

商察完

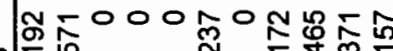

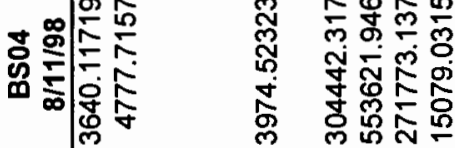

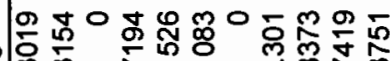

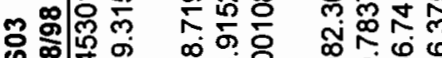

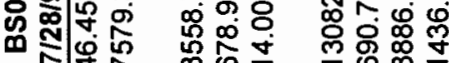

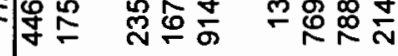

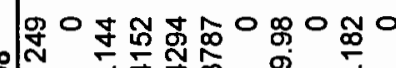

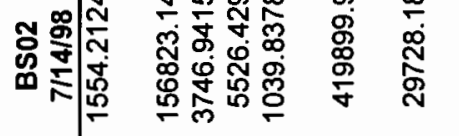

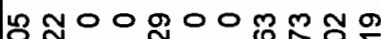

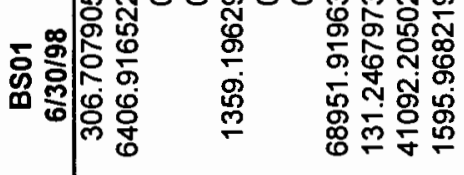

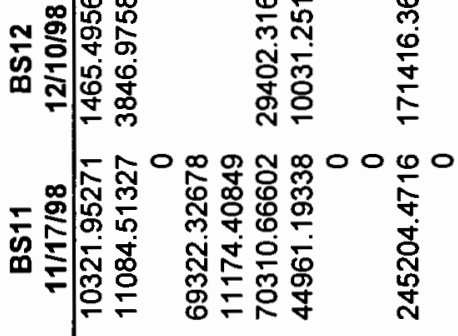

疍

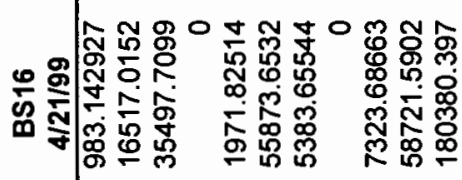

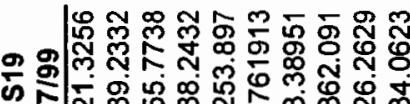

क

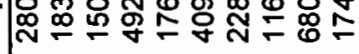

นึ้

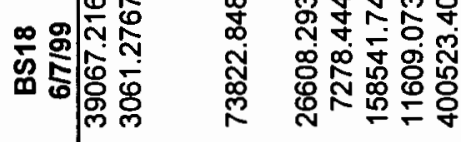

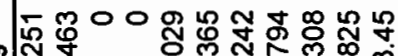

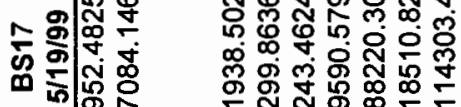

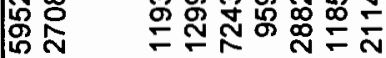

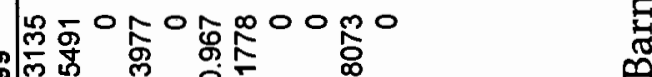

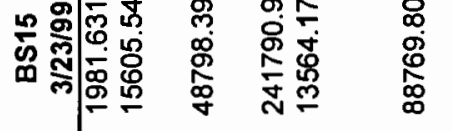

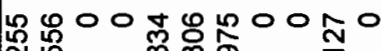

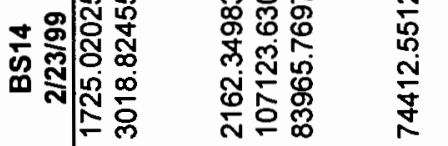

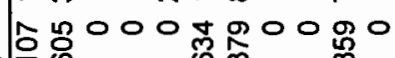

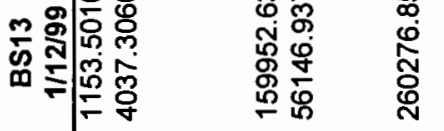

กู้

$\Xi$

$\frac{d}{4}$
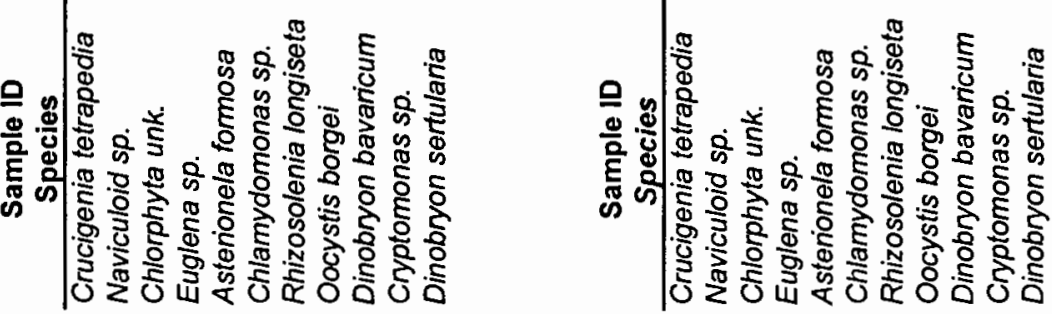


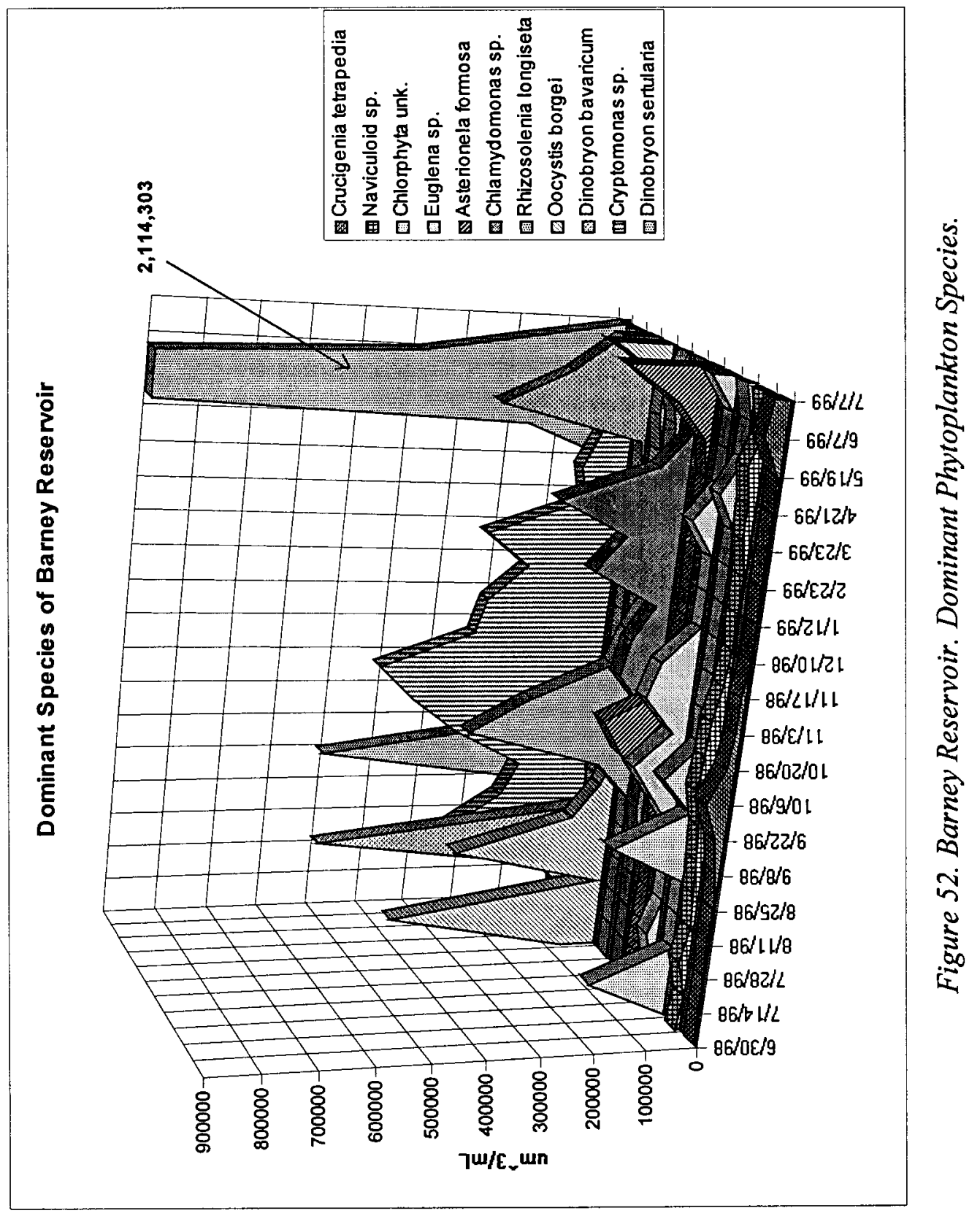




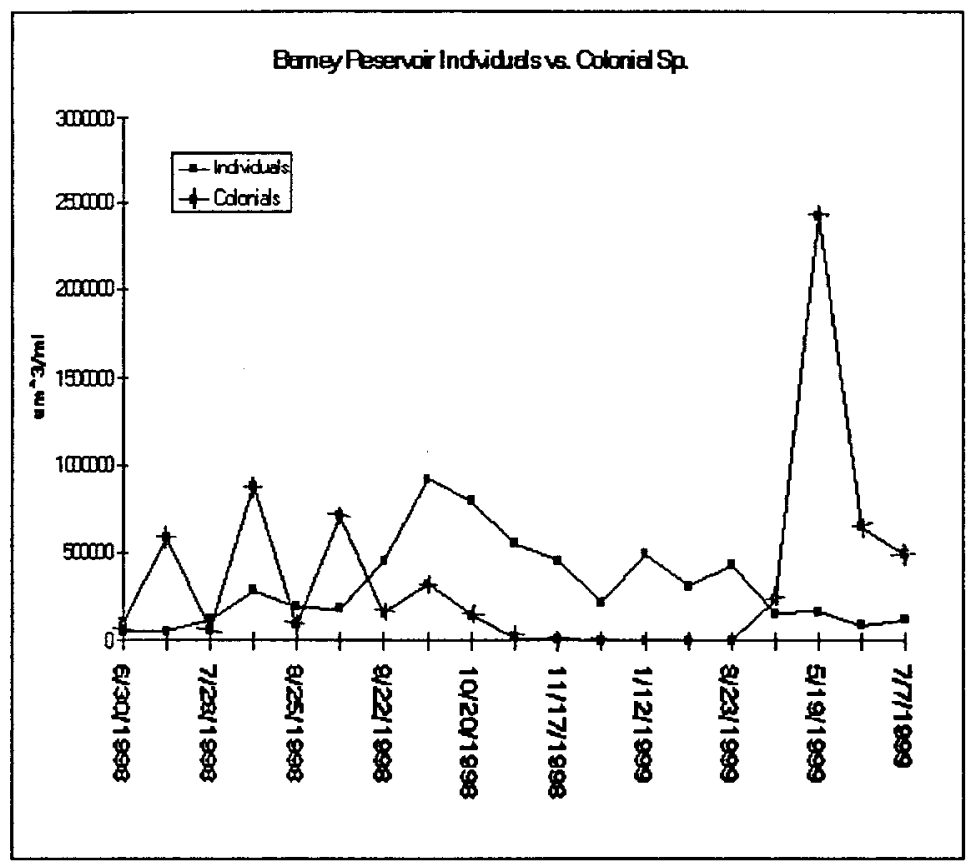

Figure 53. Barney Reservoir Total Colonial vs. Individual Species.

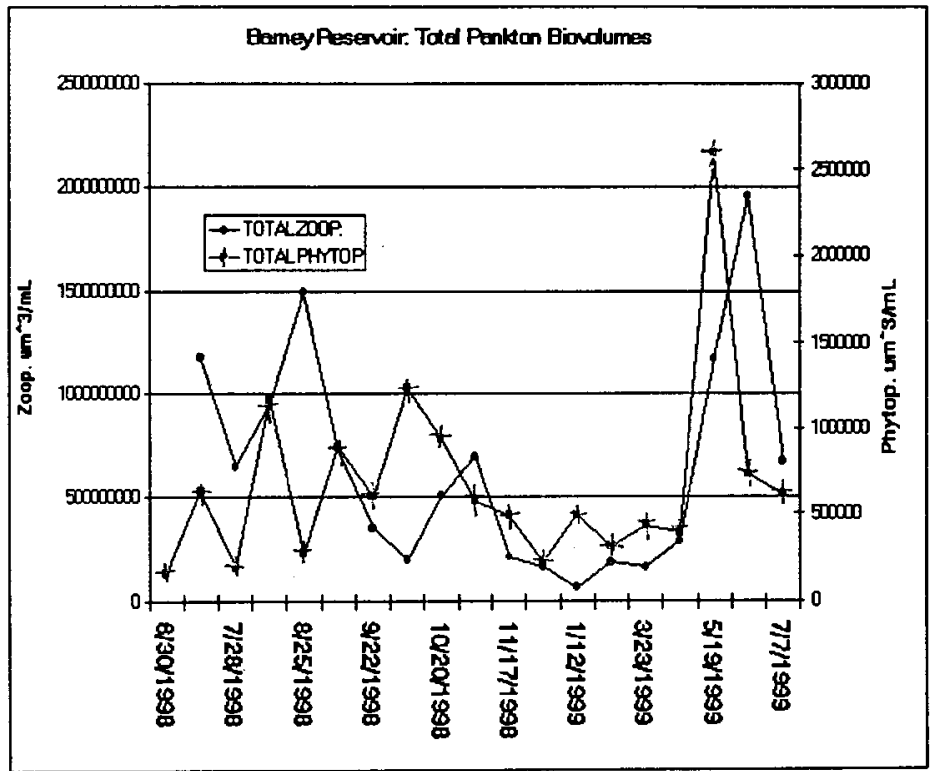

Figure 54. Barney Reservoir total biovolumes of phytoplankton and zooplankton. 


\section{Zooplankton}

The total biovolumes of the zooplankton populations in Barney Reservoir was dominated by four species. The most dominant was a species of cyclopoid, Diacyclops thomasi, a raptorial, which exerted predation pressure on the herbivorous zooplankton. The other dominant species were two species of Eucladocerans: Bosmina longirostris, a bosminid, Daphnia catawba, a daphnid, and Asplanchna priodonta, a rotifer. However, protozoans and many other species of rotifers and eucladocerans were also present in this reservoir. During this study, no live calanoids (a herbivorous zooplankton present in Hagg Lake) were encountered, only residual exoskeletons were seen.

The zooplankton species encountered in Barney Reservoir were grouped according to their feeding habits as raptorials, filter feeders, grazers and omnivores (including in the omnivores the nauplii of the copepods). The dominant groups of zooplankton according to their feeding habits were the raptorials (cyclopoids) and grazers (eucladocerans). Their dominance diminished during the period of mixing and omnivores (rotifers) increased their biovolumes. From December 1998 to March 1999 high water volumes, high outflows, and low phytoplankton biovolumes might have helped to decrease the biovolumes of all the zooplankton species. 


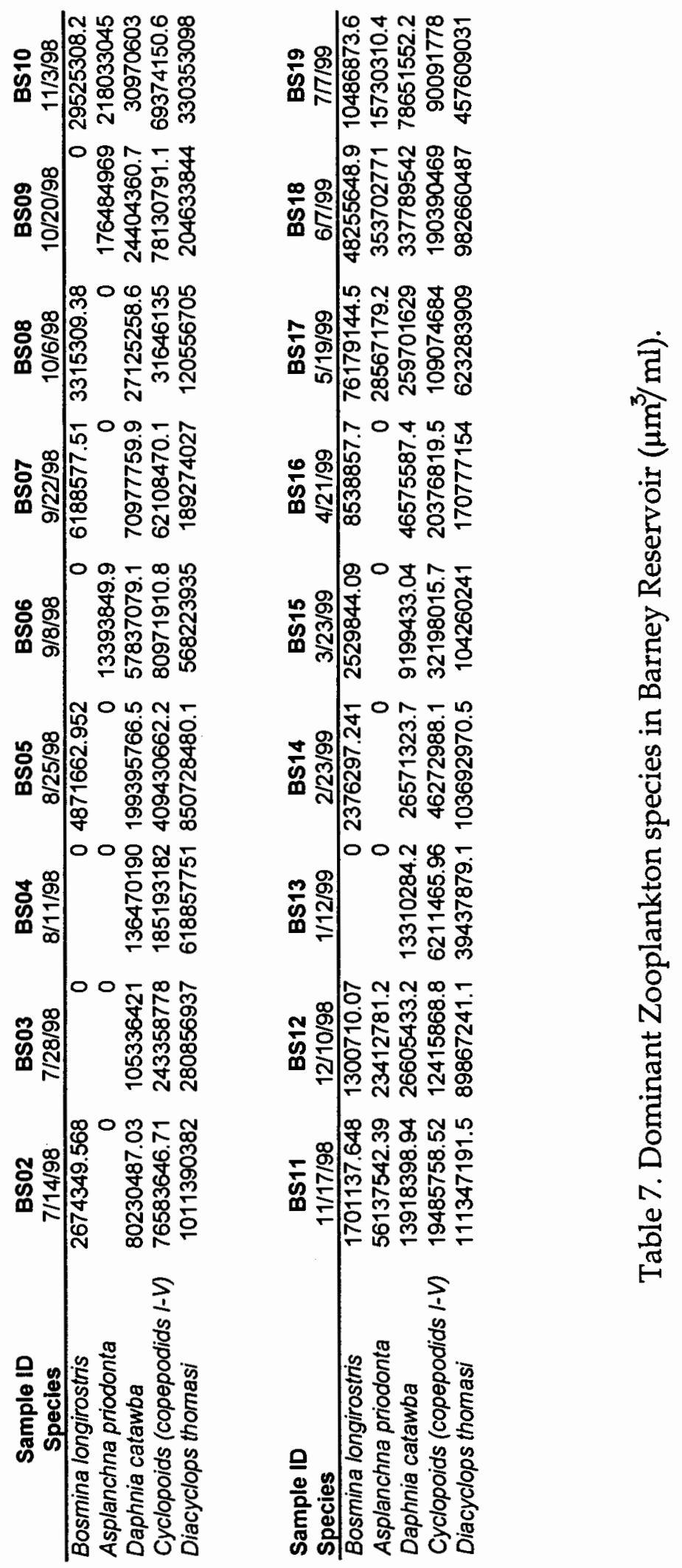




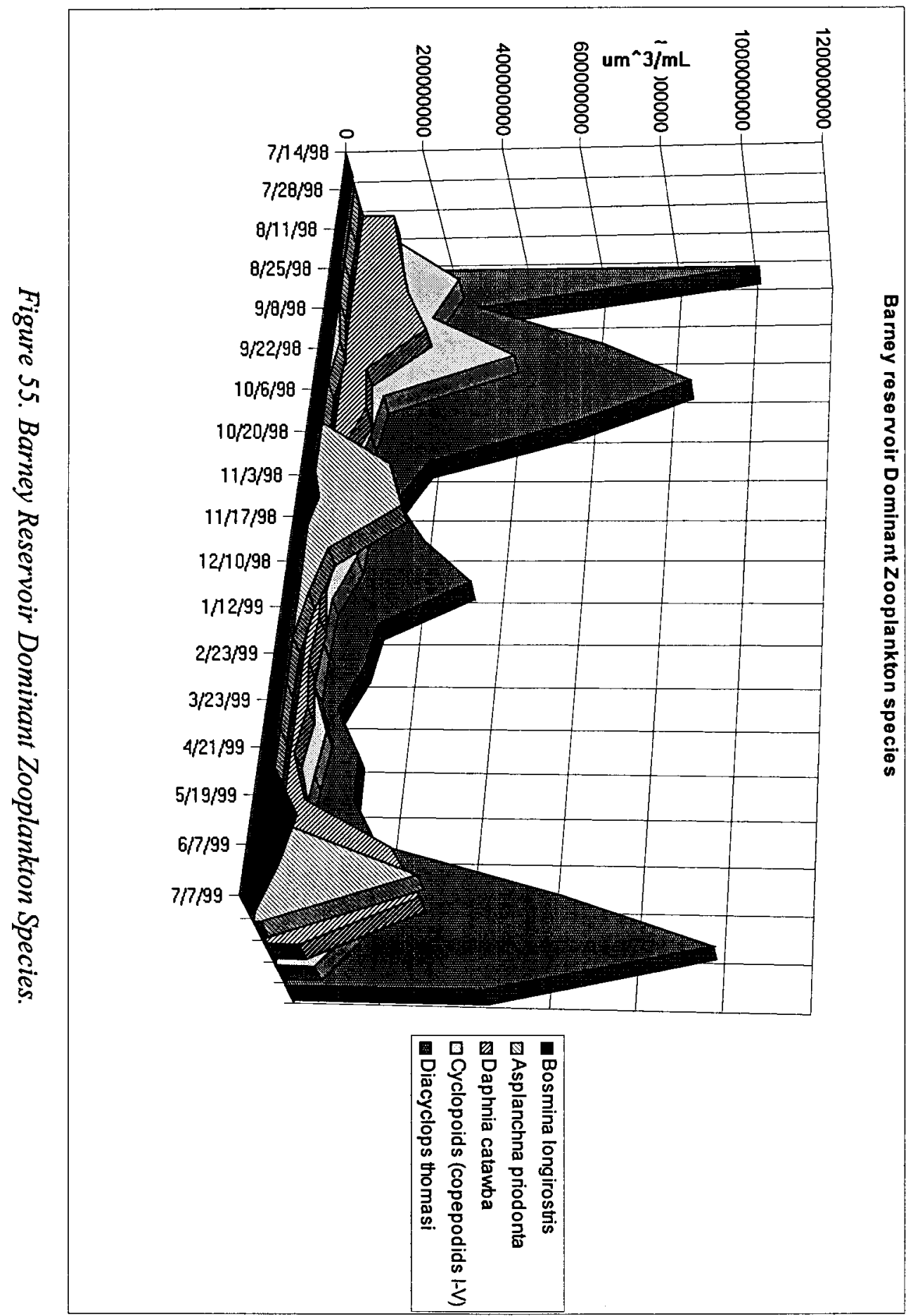




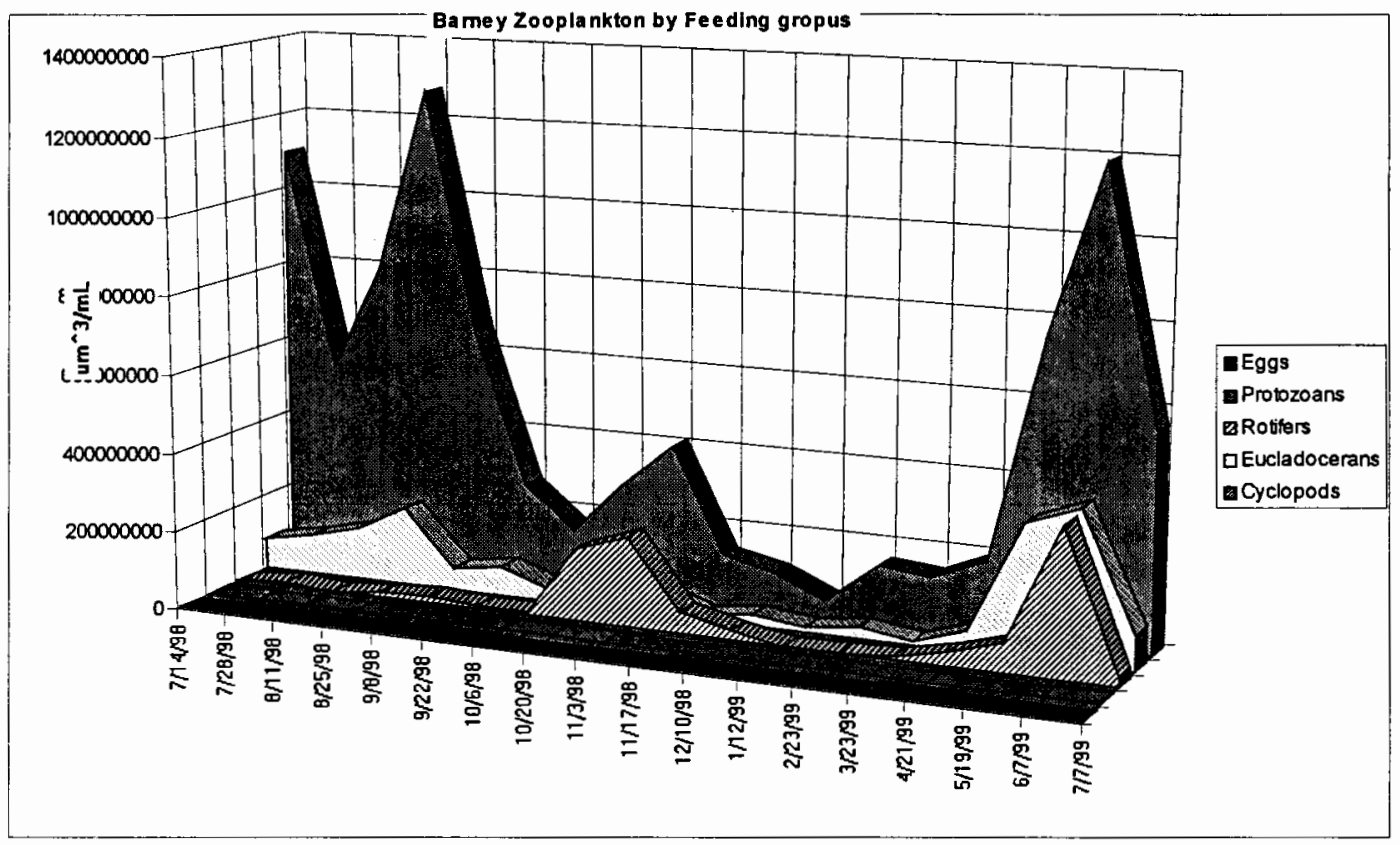

Figure 56a. Barney Reservoir zooplankton, by feeding groups (biovolumes).

When the large herbivores zooplankton and the small zooplankton species are considered apart from the large, raptorial cyclopoids, there is a clear dominance of the large bodied daphnids during the periods of stratification (June-early September 1998 and Spring 1999) and their decline occurs at the same time water levels drop and the period of mixed water column begins. From December 1998 to March 1999 a slight dominance of daphnids and Synchaeta sp. (Figure 56a and 56b). 


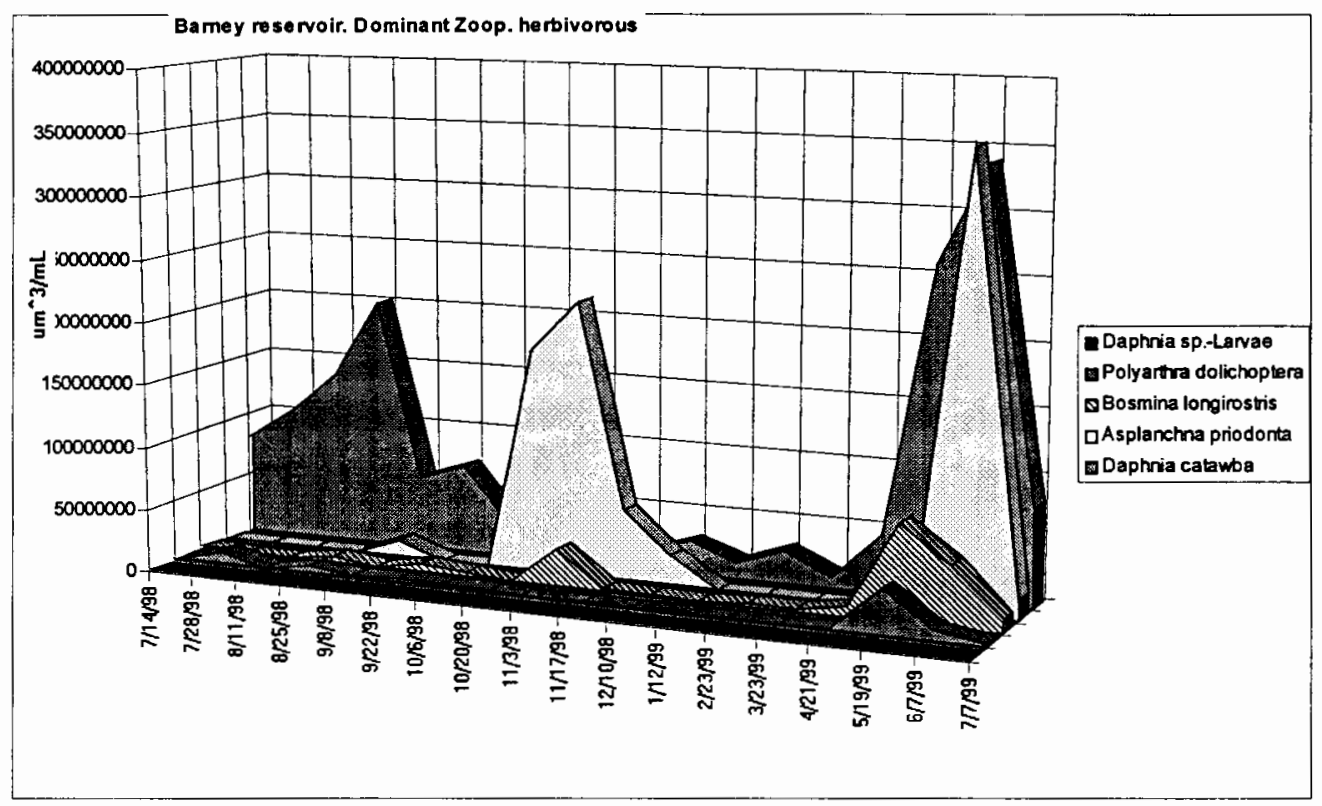

Figure 56b. Barney Reservoir Herbivore Zooplankton.

From June to mid August 1998, the total biovolumes of the herbivorous zooplankton was slightly greater than the total phytoplankton biovolumes for the same dates. From August 22, 1998 to April 21, 1999 -the period of mixed water column- the phytoplankton biovolumes were slightly greater. After April 1999, the dominance or 'bloom' of Dinobryon sp., increased the total biovolumes of phytoplankton over the zooplankton biovolumes, but afterwards the zooplankton biovolumes rose again (Figure 57). 
The prolonged mixing of the water column seemed to be an important factor controlling the plankton dynamics of Barney Reservoir, with more photosynthetic activity by the phytoplankton and greater zooplankton biovolumes occurring during the periods of stratification. While the water levels decreased or were low (September to November 1998), the effects of mixing on the phytoplankton were positive because nutrients from lower depths reached the photic zone favoring the growth of Cryptomonas sp., Rhizosolenia sp., Asterionela sp., and euglenoids among other species. As individual species dominated this short period of low water levels and mixing, small-bodied zooplankton, having less predatory and competitive pressure from larger zooplankton, were able to increase their biovolumes.

The onset of high precipitation and water volumes, low light and lower temperatures was followed by a decrease in the phytoplankton and zooplankton biovolumes. The return of stratification and more stable conditions, at the end of April 1999, favored increases in the biovolumes of cyclopoids, eucladocerans and fast swimming rotifers. 


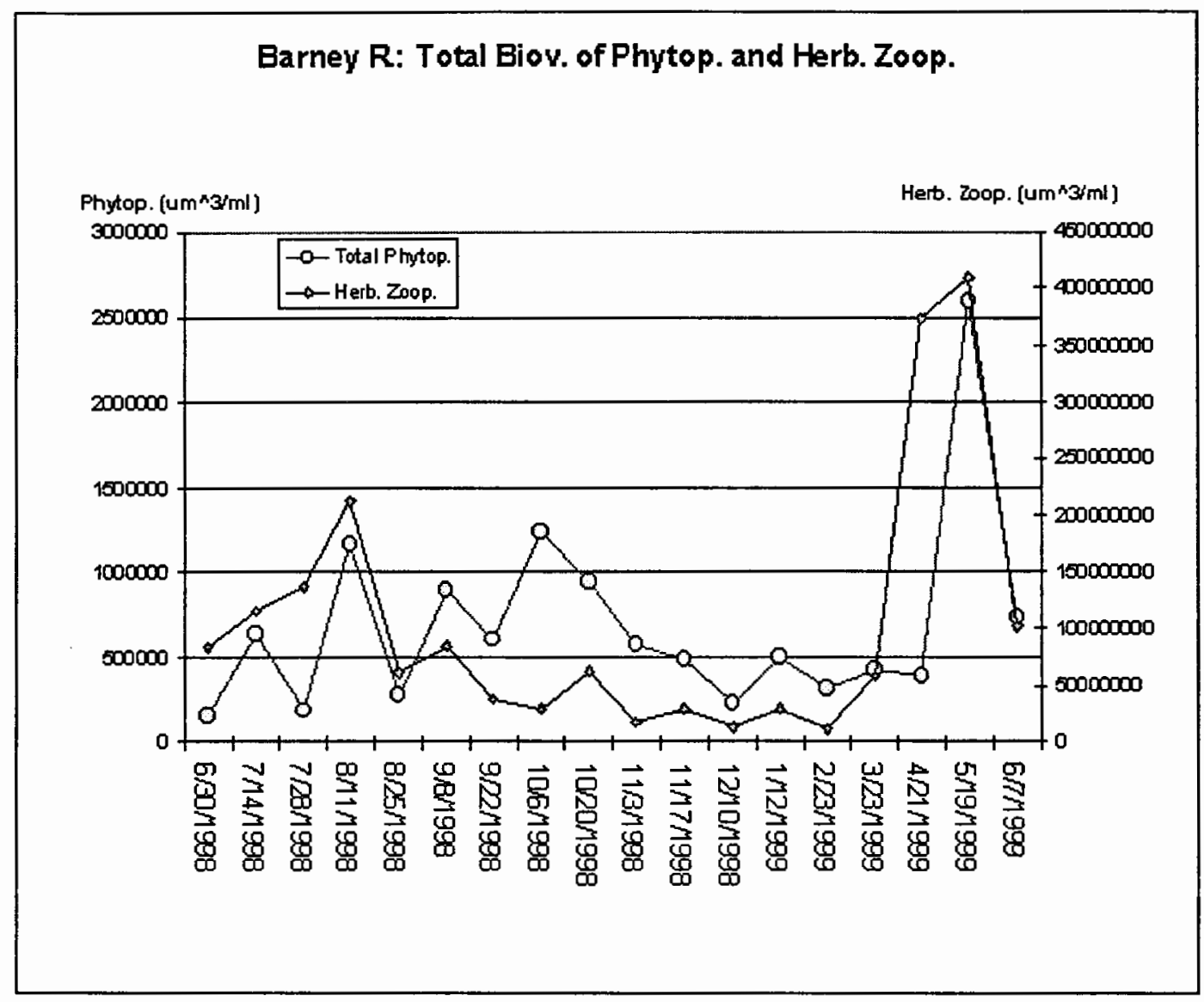

Figure 57. Barney R. Total biovolumes of phytoplankton and herbivore zoop.

\section{Fish predation}

Cutthroat trout (Oncorhynchus clarki clarki) were observed in the reservoir. During the study period, however, the reservoir was not being stocked with fish, nor was it open to recreational fishing. 


\section{Species richness}

In this study, the Shannon-Weiner index of diversity was used to measure the information content of the sample. The calculated values of this index, for zooplankton and phytoplankton in Barney Reservoir, are given in figure 58a. The average diversity measured was 1.62 bits per individual for the zooplankton and 2.04 for the phytoplankton (formula 1.0, Species diversity heading of Hagg Lake section).

The graph shows that the index for both the zooplankton and phytoplankton increases as the summer and fall 1998 progresses, and only decreases for the phytoplankton in December 1998 (1.009 bits). This decrease in the phytoplankton index could be related to increases in water volumes. The winter 1999 conditions did not seem to have a great impact on either the zooplankton and phytoplankton. During the spring of 1998, (May 1999) the phytoplankton index decreased when the Dinobryon sp. was dominant. In all of the cases when the phytoplankton index was low, dominance in the proportions to the total biovolumes was exerted by one of the species present.

The trends for the zooplankton Shannon-Weiner index is less variable since the species composition did not change much during the period of this 
study, only the dominance in total biovolumes contribution by one or another species changed (Figure 55).

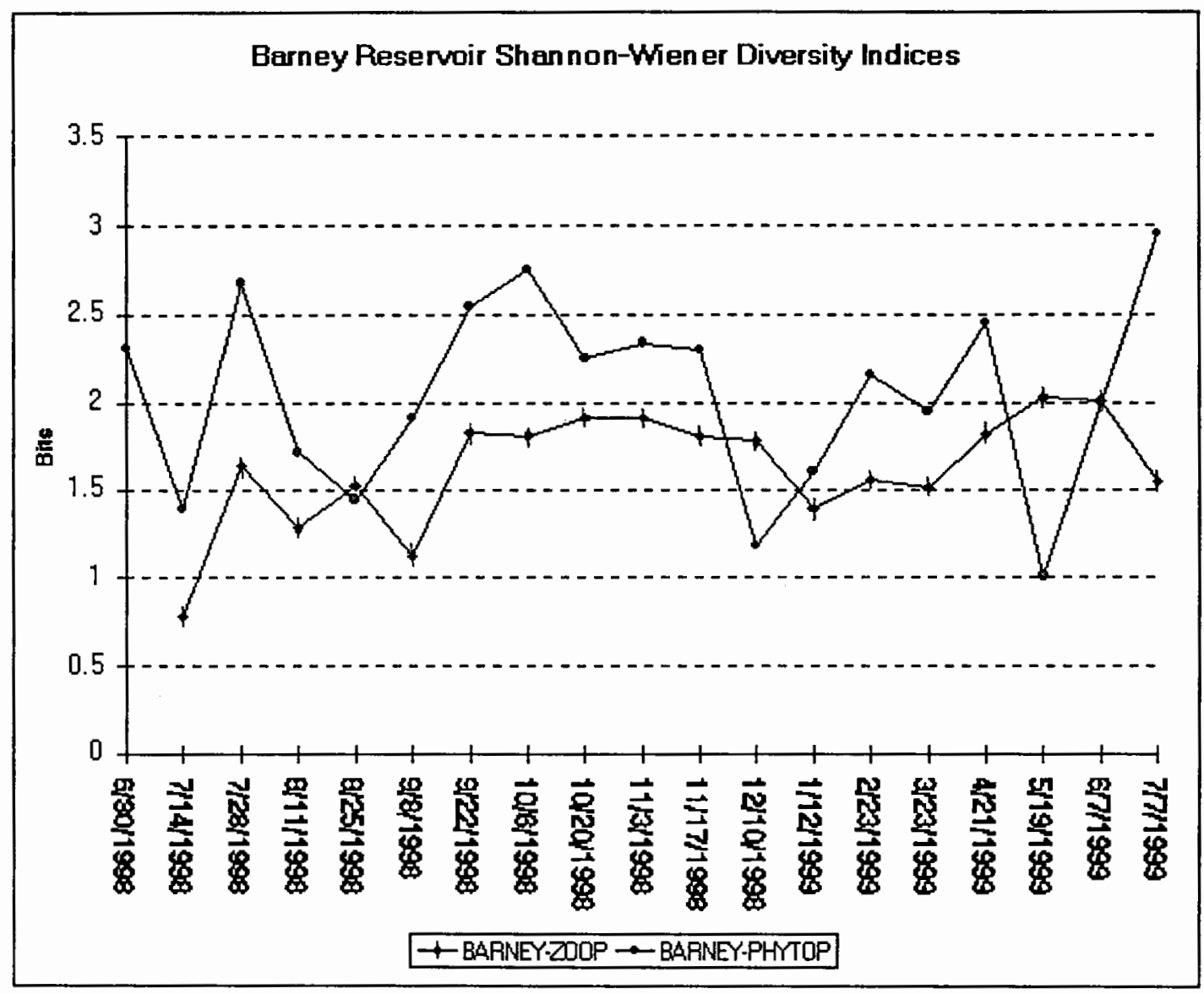

Figure 58a. Barney Reservoir Shannon-Weiner Species Diversity Index.

The normalized evenness or redundancy with a range of 0 to 1.0 was calculated as well, with 1 indicating even samples (many co-dominant species). For the phytoplankton, in Barney Reservoir the average value of evenness was 0.26 with low values in July 1998 and the lowest occurring in 
May 1999, both coinciding with Dinobryon sp. dominance (Figure 58b). The highest evenness value was calculated for the sample of July 7, 1999 at 0.407 after the Dinobryon biovolumes fell and other species began to increase their contributions to the total phytoplankton biovolumes. Fluctuations in the evenness and the Shannon-Weiner index for phytoplankton reflect the variations in the limiting nutrients (i.e. total phosphorus, figure 47 ).

Zooplankton evenness had an average normalized diversity index equal to 0.21 , a minimum of 0.155 (August 8, 1998, coinciding with a decrease of large-bodied zooplankton) and a maximum value of 0.338 (May 1999, coinciding with an increase in the large-bodied zooplankton). The only generalization that could be applied to both phytoplankton and zooplankton evenness data is that the main effect of mixing on this metric was in the form of fewer sharp changes from one sample to the next, or in other words, the species composition and their contribution to the total biovolumes was more evenly distributed during this period of turbulent mixing, low temperatures and underwater light regimes.

The seasonal observations of the changes in the Shannon-Weiner and the normalized evenness metrics are relevant because they reinforce the explanations regarding the relationships between biotic and abiotic factors 


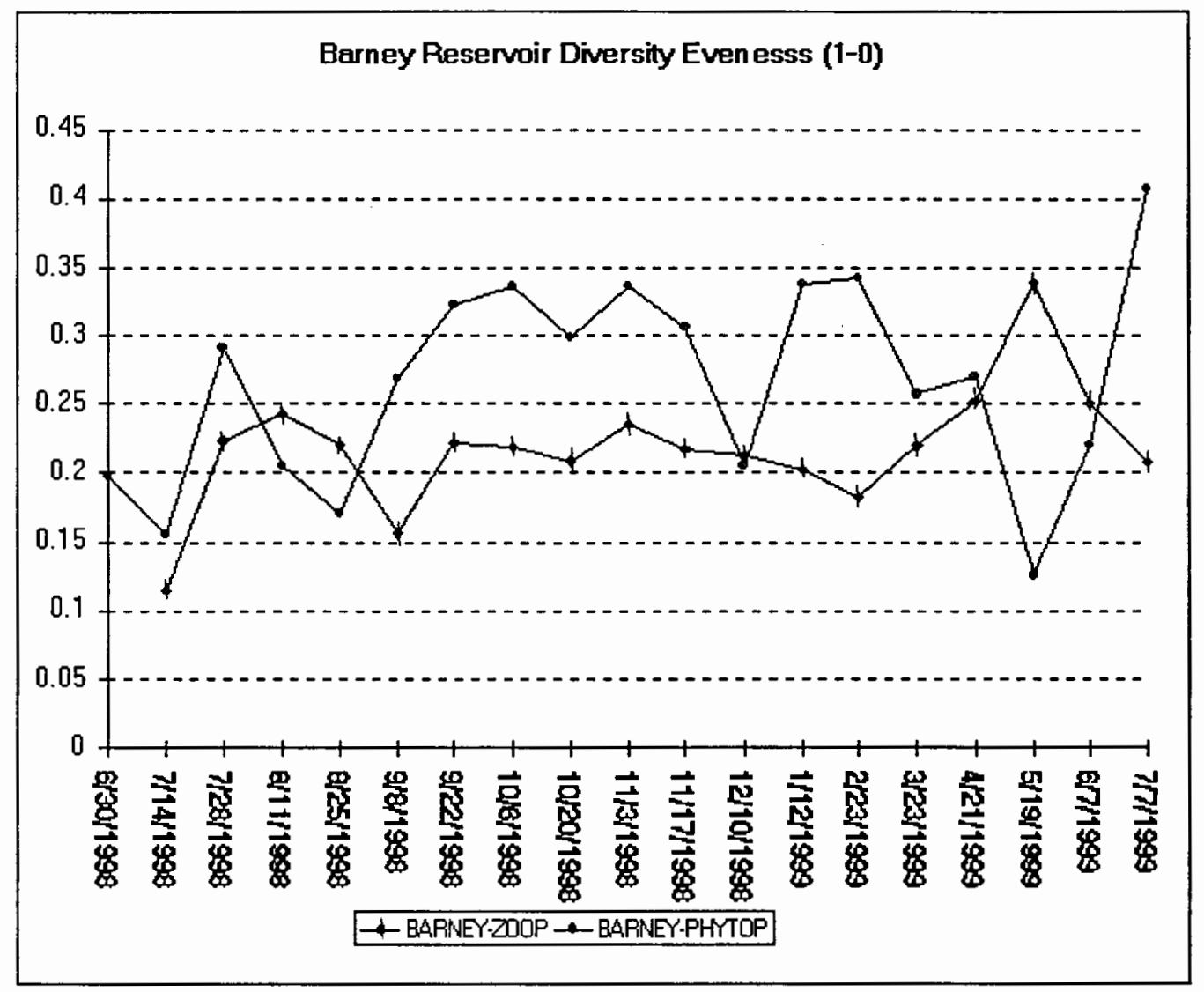

Figure 58b. Barney Reservoir Normalized (Diversity) Evenness. 


\section{SUMMARY}

Understanding the dynamics and characteristics of reservoirs is a complex and difficult task, but nonetheless achievable if a methodical approach, coupled with some awareness of the interacting factors at work, can be used to partition or select one particular dimension or problem of interest. Once this dimension is selected, the other elements left out can still be referenced to aid in explaining the changes observed.

A conceptual model was developed to identify the many dimensions and factors that define a theoretical reservoir. The chosen dimension of interest for this study, based on the theoretical model, was the dynamics of the planktonic successions from the June 1998 to early July 1999.

The PEG model for lakes was adapted to describe the plankton dynamics of Hagg Lake and Barney Reservoir. To do this the climatic regime and the geographic location were taken into consideration.

The northwest corner of the state of Oregon had a rainy, storm driven season; it began in November 1998 and lasted until April 1998 (Figure 6). The passage of these weather fronts and their accompanying winds caused constant mixing of the water columns, and changes in water levels of Hagg 
Lake and Barney Reservoir. These constant disturbances could be interpreted, from the point of view of the plankton, as a fall overturn that persists until the end of winter, when the operators of the dams allows the water levels to stabilize.

It is at this point that the PEG model begins to describe the succession of the plankton. Human influences, in terms of watershed land use practices, were also taken in consideration.

In Hagg Lake, the impact of human activities on the watershed could have caused more sediments and nutrients to enter the reservoir. For example the percentage of land used in human activities is only $3.5 \%$ and yet the overall water quality of the reservoir at the lacustrine zone is lesser than the water quality of Barney Reservoir, where no permanent human settlements existed in its watershed boundaries during the study period. Another human activity that deserves to be considered is the annual stocking of the reservoir with warm water fish, and the impact that this has on the predatory zooplankton - herbivorous zooplankton and the phytoplankton relationships. 


\section{Hagg Lake}

The geographical elements such as vegetation cover of the watershed, the orientation and closeness of the surrounding hills, the geometry of the reservoirs and the general orientation of the main axis in relation to the predominant weather patterns were important for both Hagg Lake and Barney Reservoir.

In Hagg Lake, the differences between the maximum and minimum water elevations and the water volumes were important to the yearly hypolimnetic dissolved oxygen concentrations. The hydraulic mean residence times were long enough as to be considered irrelevant in terms of the planktonic losses by washout (Reynolds, 1984). Human influences such as clear-cutting of the forests and housing developments need to be taken in consideration.

The distribution of the temperature in the water column appeared influenced by the water elevation. However the high water storage capacity of Hagg Lake could have made this influence less important by its effect on the residence times and high volumes of inflows. 
The photic zone and Secchi depth were affected by the amount of suspended materials carried into the reservoir by the main tributaries. This was evident in the observed turbidity measurements. The summer disturbances that occurred in the watershed, which increased sediment loadings to the reservoir, had a more noticeable impact on the turbidity than the larger inputs occurring during the winter.

During winter conditions, a dilution effect caused by the high inflows, the mixing of the water column and rapid settling of the particles keeps the turbidity low. During summer, inflows are less and the thermal stratification prevents mixing of the water column, as sediments enter the reservoir they will be concentrated in the underflows or overflows within the stratified water column.

The $\mathrm{pH}$ in Hagg Lake during the period of stratification seemed influenced by the photosynthetic activity of the algae in the photic zone (summer 1998). Increases in winter inflows and mixing of the water column kept the $\mathrm{pH}$ between 6.7 and 6.9. The close relationship between conductivity, redox, and $\mathrm{pH}$ was also evident in the time-depth diagrams. Low redox and dissolved oxygen values in the hypolimnion explained the observed increases in reduced nitrogen. Alkalinity, cations and dissolved inorganic carbon concentrations followed similar trends with decreases during high water inflows and high water storage. However, dissolved 
potassium was found in the low concentrations, when compared to the other cations.

Hagg Lake chlorophyll-a concentrations were a good reflection of the levels of phytoplankton activity. Summer peak values occurred at the same time that biovolumes peaks of Synedra radians, Fragilaria crotonensis and Cryptomonas sp. were noted. Winter lows of chlorophyll-a were in agreement with low phytoplankton biovolumes, low temperatures and low irradiance. Nitrogen concentrations in the epilimnion during the study period were low when precipitation and inflows were low, and increased as the rainy season progressed. Ammonium nitrogen was low, with some hypolimnetic increases during the period of summer anoxia. Epilimnetic total phosphorus concentrations were correlated with the water levels and the chlorophyll-a measurements whereas SRP concentrations were generally low $(4.26 \mu \mathrm{g}$ $\mathrm{P} / \mathrm{L})$.

Silicon measured as dissolve silica $\left(\mathrm{SiO}_{2}\right)$ was found in relatively high concentrations, and the biovolumes of the diatoms (Bacillariophycea) indicated that silicon was not a limiting nutrient for these algae.

The average of the trophic state indices (TSI) indicated that Hagg Lake could be identified as having a mesotrophic lacustrine zone. The total nitrogen - total phosphorus (TN:TP) mass ratios showed that for $37 \%$ of the time Hagg Lake was under nitrogen limitation conditions, with high TN:TP 
peaks that coincided with enhanced biological activity or with high inflows during the rainy season (November 1998 to March 1999).

\section{Barney Reservoir}

The influence of the geographical elements was more evident in the case of Barney Reservoir. Generally, the winds came from the West (Pacific Ocean), and since the main axis of Barney Reservoir is oriented in an east to west direction, these winds generated waves and influenced most of the reservoir surface and its shores.

The differences between the maximum and minimum water elevations and water volumes in Barney Reservoir were extreme (Table 1). The impact of these extreme changes was noticeable on the water column mixing dynamics. As a result the changes in water volume and period of mixing played an important role in determining the succession of both the phytoplankton and the zooplankton.

The hydraulic mean residence time was moderate and could not be linked to planktonic losses by washout. Another important element controlling the planktonic dynamics of this reservoir during this study period was the low impact of human activities reflected in the percentage of vegetation cover of the watershed (93.6\%). High vegetation cover and low 
human influences had as consequence a surface runoff with low nitrogen, phosphorus and sediment loadings from runoff. This in turn caused the waters of Barney Reservoir to have low concentration of nutrients, higher average photic depth and relatively low chlorophyll-a concentrations, particularly when compared with Hagg Lake.

The distribution of the temperature in the water column was definitely influenced by the changes in water elevation and water storage. These changes forced the hypolimnetic waters to warm up considerably and the dissolved oxygen concentration to diminish. Also, as water levels dropped, the kinetic energy necessary for the wind to mix the water column was less, and thus mixing began in the middle of September 1998. With increases in the water elevation and water volumes, the photic zone and Secchi depth were affected but not in the same degree that Hagg Lake was. Turbidity was more influenced by falling water levels than by increased water levels, likely due to sediments being disturbed as the waters receded from the small coves of the reservoir.

The epilimnetic $\mathrm{pH}$ of Barney increased during the period of stratification and high biological activity, and decreased in the hypolimnion. Epilimnetic redox was low during the summer and appeared influenced by the biological activity. Hypolimnetic redox was slightly higher that 
epilimnetic redox and reinforced the hypothesis that hypolimnetic anoxia in Barney Reservoir was temperature controlled.

The pattern of the epilimnetic conductivity was similar to the pattern for the cations and alkalinity concentrations, with higher values during the period of low and decreasing water levels (concentration effect), and lower concentrations when inflows and water volumes began rise (dilution effect). However, dissolved potassium was found in the low concentrations, when compared to the other cations.

The epilimnetic chlorophyll-a in Barney Reservoir was relatively low, with higher activity during the period of low water elevation and higher temperatures. Low light conditions and lower temperatures could have contributed to low chlorophyll-a measurements during the winter of 1999. As in the case of Hagg Lake high chlorophyll-a values were linked to high phytoplankton biovolumes (Cryptomonads sp. and Dinobryon sp.).

Total nitrogen concentrations were generally less than $200 \mu \mathrm{g} \mathrm{N} / \mathrm{L}$ and the only increase occurred at the start of the rainy season. The likely explanation was that nitrogen trapped in the sediments might have been resuspended by the onset of the rainy season and increases in water volumes. Nitrate+nitrite nitrogen had a similar occurrence. Ammonium nitrogen was generally low, with concentrations near the detection limits. The dynamics of phosphorus was difficult to appraise because of the low total phosphorus 
and suspended reactive phosphorus concentrations, thus it can be said that Barney Reservoir is phosphorus limited.

Concentrations of dissolved silica $\left(\mathrm{SiO}_{2}\right)$, was relatively high, with an average concentration of $12.4 \mathrm{mg} \mathrm{SiO}_{2} / \mathrm{L}$. The only decrease in concentration coincided with a peak of diatom biovolumes.

The average of the trophic state indices (TSI) indicated that Barney Reservoir could be identified as having a mesotrophic lacustrine zone. The calculated total nitrogen - total phosphorus (TN:TP) mass ratios showed that for $27 \%$ of the time Barney Reservoir was under nitrogen limitation conditions. However, relatively low phosphorus concentrations were more common as reflected by the chlorophyll-a. The information from the silica phosphorus mass ratios was obscured by the low phosphorus and high silica concentrations. 


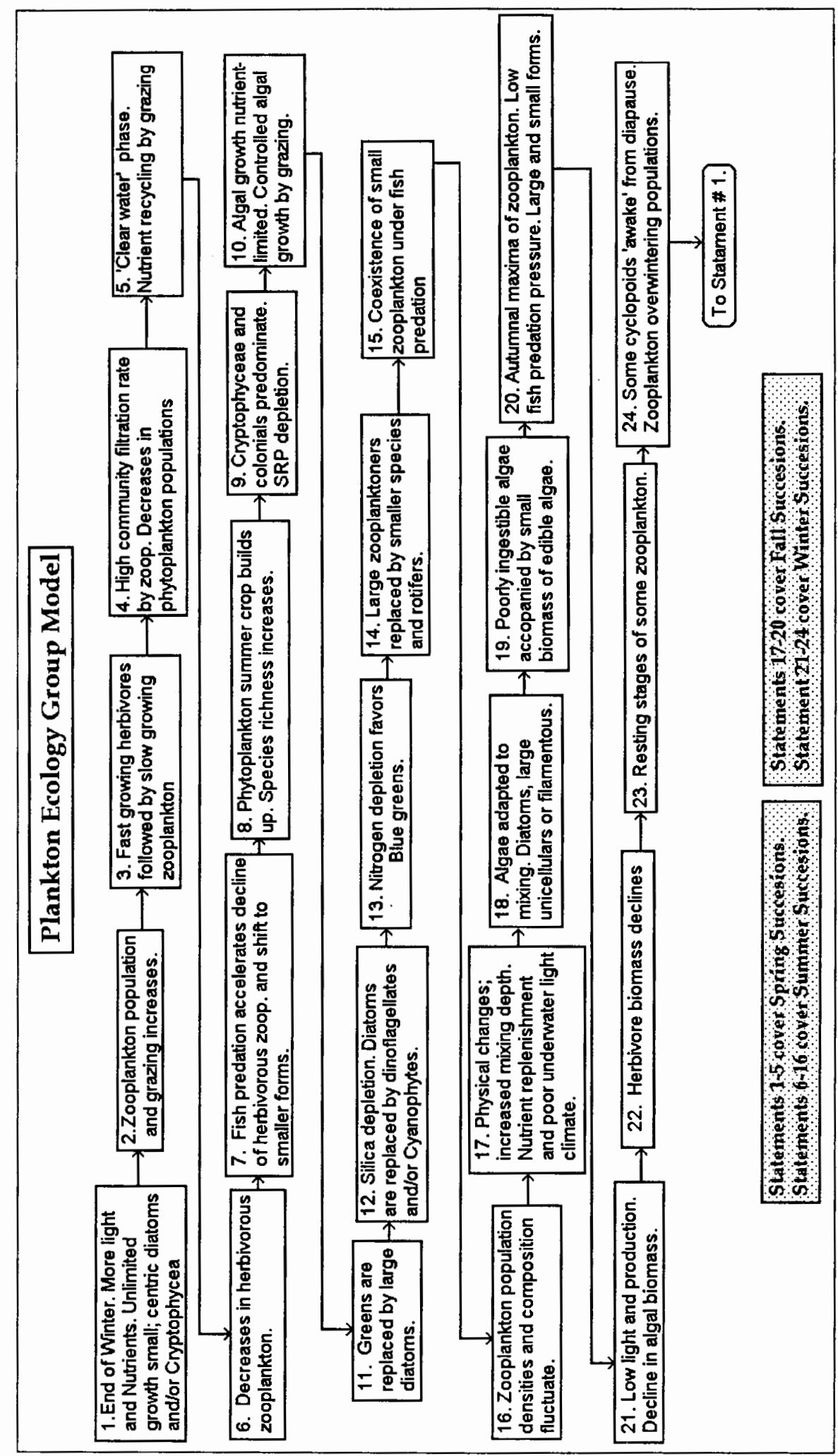

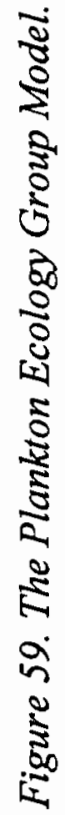




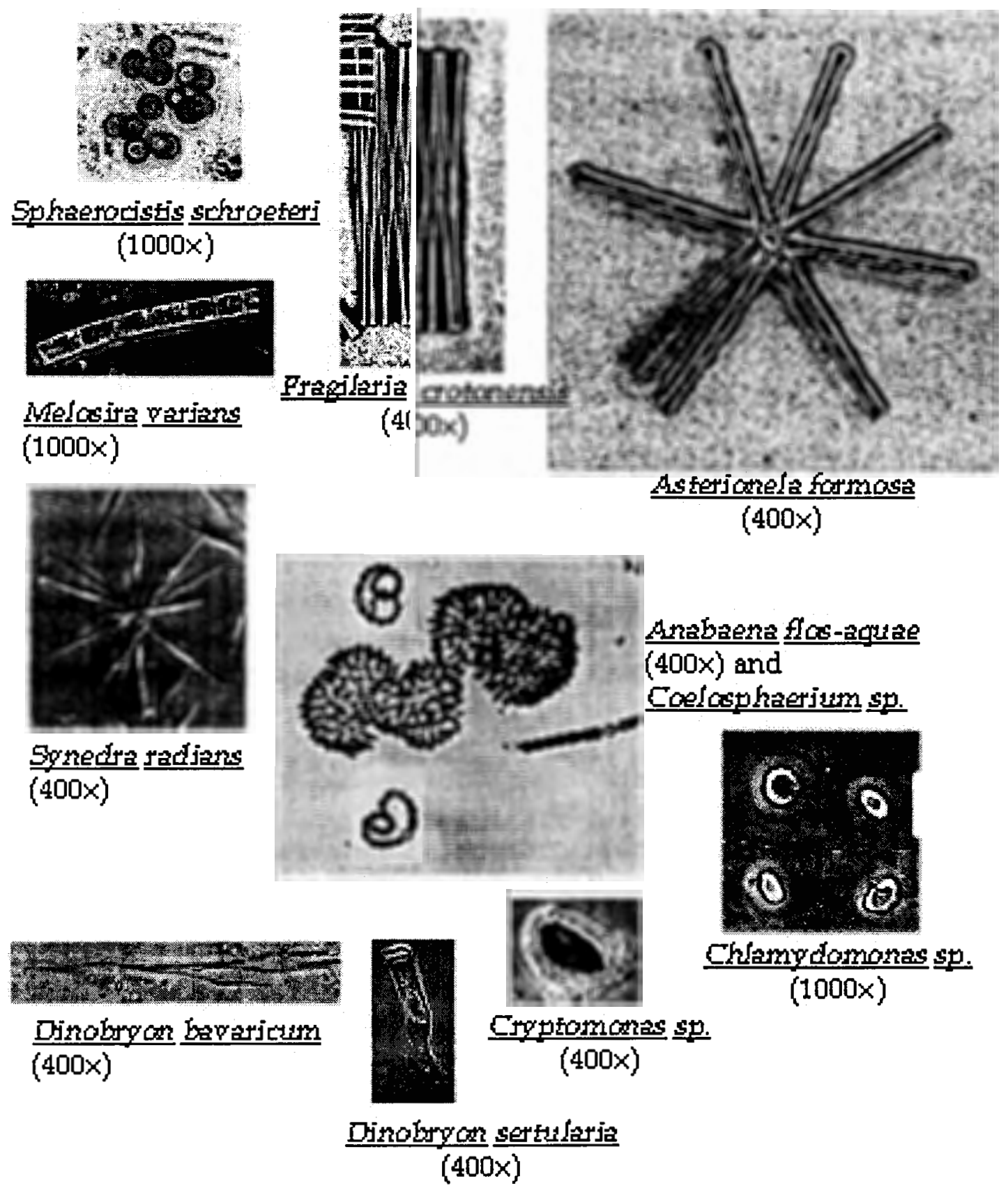

Figure 60a. Selected microphotographs of Hagg Lake phytoplankton. 


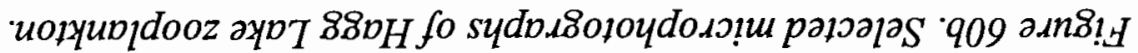

$(\times 001)$

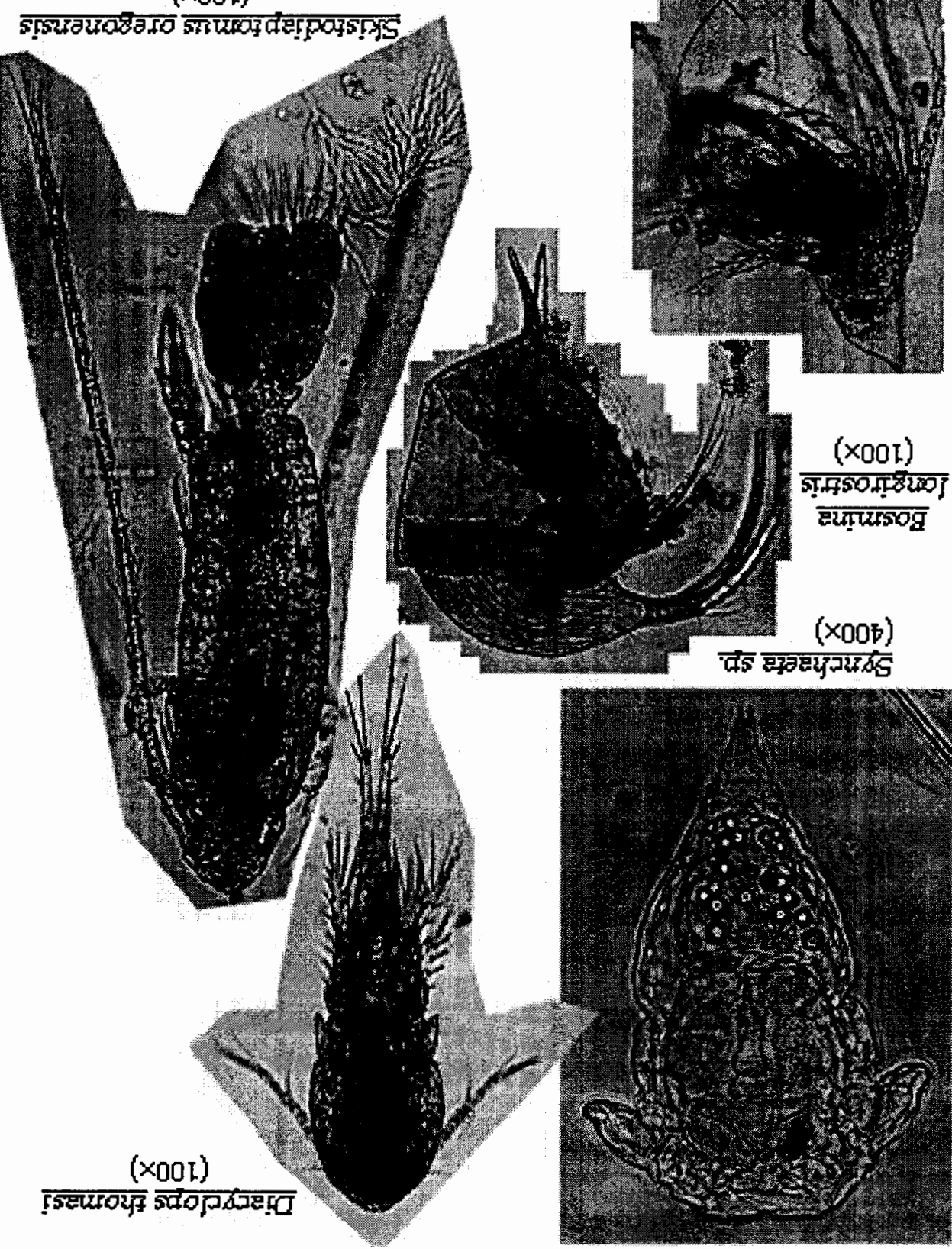




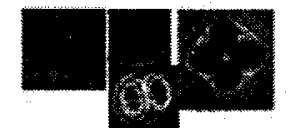

Oocystis borgei $(1000 x)$

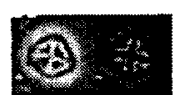

Crucigenia tetrapedia (1000x)

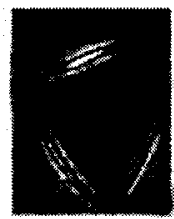

Ankistrodesmus falcatus (1000x)

\section{3}

Rhizosolenia longiseta $(1000 x)$

\section{Barney Reservoir Phytoplankton}

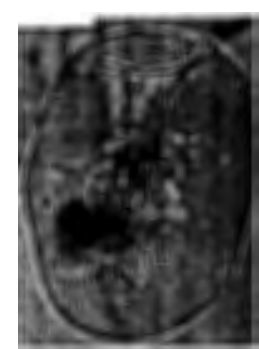

Asplanchna priodonta $(400 x)$

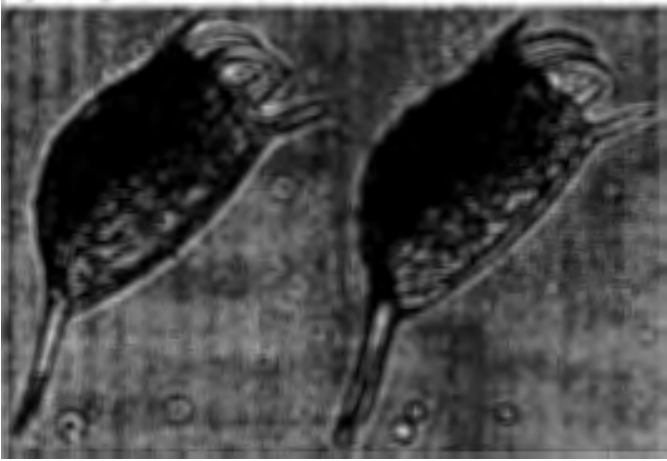

Keratella cochlearis

(400x)

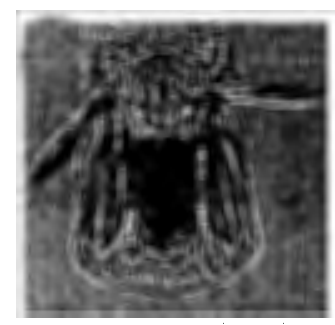

Polvarthra doliochoptera $(400 x)$

\section{Barney Reservoir Zooplankton}

Figure 61. Selected microphotographs of Barney R. Plankton. 


\section{DISCUSSION}

\section{Conceptual Model}

A conceptual model was developed to identify the dimensions and interacting factors that define a theoretical reservoir. Based on this model, data from the variables measured were used to make inferences between the interactions of the physical and chemical components and the effects or responses of the plankton to these interactions.

\section{$\underline{\text { PEG Model }}$}

The verbal model of plankton ecology group (PEG) was used to describe the plankton dynamics in both Hagg Lake and Barney Reservoir. This model, although suited to natural lakes, was a good predictor of the late spring to late fall 1998 and spring 1999 planktonic successions (Figure 59).

\section{$\underline{\text { PEG Model and Hagg Lake }}$}

The PEG model was used to describe the plankton dynamics in the lacustrine zone of Hagg Lake (Figure 59). Statements 1 to 5: These statements described the spring phytoplankton- herbivorous zooplankton dynamics. In Hagg Lake what could be termed a 'clear phase' period (in the form of photic 
zone depth) occurred in June 1998 and July 1999 with depths of around 7.5

m.

The statements 6 to 16 of the PEG model described the summer planktonic succession. In Hagg Lake these statements apply, although in not the same order. For example, as fish are used to stock the reservoir, the impacts of its predation are perceptible through the decline of the large bodied zooplankton (including the cyclopoids). However, unlike in natural lakes, the decreases in water levels can cause a particular sequence to repeat itself, as nutrients can be re-suspended while water temperatures are relatively high or if light limitation caused by mixing-induced turbidity occurs. In late summer, when most of the fish predation pressure is gone, calanoids (grazers) biovolumes increased partly because the biovolumes of adult cyclopoids were minimal. These large grazers can potentially outcompete smaller zooplankton. Thus, in the late summer of 1998, phytoplankton species such as Dinobryon sertularia, Chlamydomonas sp. and Cryptomonas $s p$. increased providing support for a late summer population of calanoids, bosminids, small Keratella sp., fast swimming Polyarthra sp. and big transparent Synchaeta sp.

The statements 17 to 24 described the fall and winter planktonic succession. For Hagg Lake the rainy season (November 1998 to March 1999) 
causes increases in the inflows and the water storage of the reservoir.

Turbidity increases and the light regime deteriorates. The effects of these physical changes are low photosynthesis and a decrease in the biovolumes of the large-bodied zooplankton. During this period, Hagg Lake can be described by two fall $(17,18)$ and three winter statements $(21,22,23)$. It is interesting to note that it was during the late winter period that the diversity index for zooplankton was higher.

At the beginning of spring 1999 the waters stratified, and the succession was started again with increases in biovolumes of small phytoplankton and herbivorous zooplankters (Chlamydomonas sp., Cryptomonas sp. eucladocerans, copepods, and some rotifers).

\section{PEG model and Barney Reservoir}

The PEG model was used to describe the plankton dynamics in the lacustrine zone of Barney Reservoir (Figure 59). The study period of Barney Reservoir began at the time of the June 1998 clear-water phase, and ended at the time of clear phase in 1999. The dominant species of the phytoplankton by biovolume were colonial species rather than centric diatoms; daphnids and rotifers dominated the herbivorous zooplankton succession. The phytoplankton and zooplankton diversity were relatively high, particularly after the Dinobryon sp. ceased to dominate the phytoplankton succession (Statements 1-5). 
In Barney Reservoir, the PEG statements 6 to 16 apply, although in not the same order. Information on all the kinds of fish living in the reservoir was not available and some fish predation on the zooplankton is suspected. The dominance of daphnids (by biovolumes) decreased slowly during the summer of 1998 and was replaced by the slight dominance of rotifers and bosminids. Colonials (Chrysophytes and Chlorophytes) were replaced by smaller cryptomonads and some colonial diatoms. The early start of the period of mixing interrupted the planktonic succession, and non-colonial species dominated the succession for the rest of the summer and early fall.

During this period of mixing (September 1998 to March 1999), Barney Reservoir can be described by two of the PEG fall $(17,18)$ and two PEG winter statements $(21,23)$. In Barney Reservoir, the early start of the period of mixing together with the relatively high water temperatures and the resuspension of nutrients allowed for a standing crop of cryptomonads and other algae. These algae in turn appeared to sustain many rotifers, and these in turn supported a population of predatory Asplanchna sp. (another rotifer). With a decrease in temperatures, and increases in water volumes the biovolumes of the zooplankton and phytoplankton diminished for the remaining of the winter. Cryptomonads and Chlamydomonas were the dominant phytoplankton groups; eucladocerans and a few rotifers were the 
dominant phytoplankton groups; eucladocerans and a few rotifers were the dominant zooplankton. In the spring of 1999 the reservoir stratified, cryptomonads were replaced by colonial phytoplankton and the biovolumes of the zooplankton increased again. 


\section{CONCLUSION}

From June 1998 to July 1999, the dynamics of the plankton in Hagg

Lake and Barney Reservoir were studied through the identification of their seasonal succession. The relationships between the planktonic successions and the physical and chemical variables were explored with the aim of identifying the abiotic conditions that could be used as indicators or predictors of shifts in the successions of the plankton.

The close proximity between the two reservoirs and similar land soils and vegetation cover within their watersheds justified the assumption of similar species succession. However, the species that dominated the successions (by biovolumes) in each reservoir were different.

Human activities in the form of agricultural and logging practices had an impact on the turbidity and nutrient dynamics of Hagg Lake, particularly during the summer season. The watershed of Barney Reservoir during the study period had no permanent human settlements, logging or agricultural activities. This reservoir also had a less variable nutrient dynamics and a higher average photic zone depths.

A conceptual model was developed to identify the dimensions and interacting factors that define a theoretical reservoir. Based on this model, 
data from the variables measured were used to make inferences about the interactions of the physical and chemical components and the effects or responses of the plankton to these interactions. From the observations of these interactions the following statements can be made:

1. Hagg Lake and Barney Reservoir have a mesotrophic lacustrine zone.

2. Human impacts in the watershed (logging, road construction and human habitation) of Hagg Lake have important consequences to the nutrient and turbidity regimes at the sampling station, during the study period. In Barney Reservoir the human impacts were almost non-existent and this resulted in low but stable nutrient and turbidity regimes during the study period.

Hagg Lake:

3. Dissolved oxygen in Hagg Lake appeared to be regulated by changes in the water levels, and by the changing depth from the water surface to the intake structure. Hypolimnetic anoxic conditions occurred in the late summer at the same time withdrawals from the lower epilimnion occurred.

4. Summer disturbances in the watershed of Hagg Lake that increased the sediment loadings in the creeks that feed the reservoir, had a greater impact on the turbidity than the normal winter loadings. However these 
summer turbidity impacts were localized by the placements of the inflows (according to the water temperature of the water of the creeks) in the water column.

5. The concentrations of nutrients in Hagg Lake were low when inflows were low, and increased as the rainy season progressed. Relatively high concentrations of nutrients make Hagg Lake less likely to be under nutrient stress than Barney Reservoir, despite the fact that according to the TN:TP mass rations, Hagg Lake had slightly more instances of TN:TP mass ratios less than 7 than Barney Reservoir did.

Barney Reservoir:

6. Changes in the water elevation influenced the temperature regime of the water column of Barney Reservoir; the hypolimnetic waters warmed as the water levels dropped, and could have caused temperature-related anoxia.

7. The extreme differences between the highest and lowest water levels had as consequence an early start of the long period of wind-induced mixing (September 1998 to April 1999).

8. Low water levels caused re-suspension of nutrients in Barney Reservoir. This was more noticeable in the case of total nitrogen concentrations. 
The PEG model was used to describe the plankton dynamics in both reservoirs. This model, although suited to natural lakes, was a good predictor of the late spring to late fall 1998 and spring 1999 planktonic successions. Based on the fall 1998 to early spring 1999 discrepancies between the predicted sequence and the observed succession two general statements could be made.

1. In Hagg Lake, the high winter inflows and mixing caused by the prevailing winds from the late fall to early spring weather systems, did not allow a stable winter - spring succession. Species adapted to low light, mixing, and low temperatures were common, and supported small and a few large herbivorous zooplankton population. Predation by cyclopoids and fish seemed to be the factors controlling the succession of the herbivorous zooplankton in Hagg Lake.

2. The early start of mixing in Barney Reservoir interrupted the fall succession as described in the PEG model, and a continuous resetting of the succession favored population of cryptomonads, which sustained small zooplankters. With increases in water volumes, lower temperatures and low available light the biovolumes of the phytoplankton and zooplankton decreased. If calanoids reach Barney Reservoir, they appear to be killed off by the cyclopoids since planktivorous fish and insect larvae did not seem to exert much predatory pressure on the cyclopoid population. 
From the previous statements, I conclude that:

a) The development of conceptual models to identify the dimensions and interacting factors that define a reservoir under study is not only useful but should be a requirement if a more general model of planktonic dynamics is to emerge.

b) The PEG model needs to be modified when applying it to reservoirs. This is true for those periods when the water levels and water volumes change dramatically such as during the period of winter storms or late fall withdrawals. The PEG model needs to be modified to include longitudinal variations in the concentrations of nutrients and the effects of the convective and dispersive forces on the distribution of other variables as water volumes change and synoptic cycles occur.

Finally, a hypothesis is put forth regarding the changes in plankton dynamics should fish stocking be initiated in Barney Reservoir: as fish exert more pressure on cyclopoids, calanoids will be able to colonize the reservoir. In turn Dinobryon sp. or other grazing-resistant colonial algae, adapted to low nutrients, will become more abundant, and the resulting succession will resemble more closely the planktonic successions in Hagg Lake. If changes in the land use practices occur, such as more human impact in the form of 
settlements or clear-cutting of the forested areas, nutrient inputs and turbidity will increase with a detrimental effect on the water quality of Barney Reservoir. 
Depth $(m)$

Secchi (m)

Ave_Extint_Coef.

Photic Depht (m)

$\mathrm{Ca}(\mathrm{mg} / \mathrm{l})$

$\mathrm{K}(\mathrm{mg} / \mathrm{l})$

$\mathrm{Mg}(\mathrm{mg} / \mathrm{l})$

$\mathrm{Na}(\mathrm{mg} / \mathrm{l})$

Tot-N (ug/l)

NO2-NO3 (ug/l)

$\mathrm{NH} 4$ (ug/l)

Tot-P (ug/l)

SRP (ug/l)

SiO2 (mg/l)

Ch-A (ug/l)

Alka (uEq/l)

Alka-CaCO3 (mg/L)

Temperature ( $\mathrm{d} \mathrm{C}$ )

DO (mg/L)

$\mathrm{pH}$

Cond. (uS/cm)

Turbidity (NTU)

DO (\%)

RedoX (mv)

$\mathrm{DIC}(\mathrm{mgCl})$

TN:TP

TSI-Cha

TSI-S

TSI-TP

Si:TP

DIN(or SRN)

SRN:SRP
Hagg Lake

Standard Standard Sample

Mean Deviation Error Variance

\begin{tabular}{|c|c|c|c|c|}
\hline 19 & 27.45 & 4.52 & 1.04 & 20.42 \\
\hline 19 & 2.32 & 1.35 & 0.31 & 1.82 \\
\hline 19 & 1.39 & 1.53 & 0.35 & 2.35 \\
\hline 19 & 5.17 & 2.34 & 0.54 & 5.5 \\
\hline 19 & 3.58 & 1.05 & 0.24 & 1.1 \\
\hline 19 & 0.19 & 0.07 & 0.02 & 0 \\
\hline 19 & 1.73 & 0.34 & 0.08 & 0.12 \\
\hline 19 & 4.78 & 1.25 & 0.29 & 1.57 \\
\hline 19 & 168.14 & 156.32 & 35.86 & 24435.06 \\
\hline 16 & 86.74 & 123.18 & 30.79 & 15173.06 \\
\hline 18 & 17.37 & 24.77 & 5.84 & 613.4 \\
\hline 18 & 15.71 & 8.43 & 1.99 & 70.99 \\
\hline 18 & 4.26 & 2.52 & 0.59 & 6.33 \\
\hline 19 & 12.48 & 3.19 & 0.73 & 10.18 \\
\hline 19 & 3.67 & 4.65 & 1.07 & 21.64 \\
\hline 19 & 528.55 & 120.98 & 27.76 & 14636.65 \\
\hline 19 & 25.06 & 5.11 & 1.17 & 26.12 \\
\hline 19 & 16.58 & 6.62 & 1.52 & 43.8 \\
\hline 19 & 9.75 & 1.5 & 0.34 & 2.25 \\
\hline 19 & 7.53 & 0.47 & 0.11 & 0.22 \\
\hline 19 & 56.76 & 7.54 & 1.73 & 56.88 \\
\hline 19 & 23.68 & 16.44 & 3.77 & 270.23 \\
\hline 19 & 99.64 & 8.76 & 2.01 & 76.7 \\
\hline 19 & 386.84 & 25.82 & 5.92 & 666.47 \\
\hline 19 & 0.15 & 0.04 & 0.01 & 0 \\
\hline 18 & 11.96 & 7.6 & 1.79 & 57.68 \\
\hline 19 & 36.25 & 12.83 & 2.94 & 164.68 \\
\hline 19 & 50.84 & 10.34 & 2.37 & 106.87 \\
\hline 18 & 41.51 & 9.07 & 2.14 & 82.31 \\
\hline 18 & 1059.87 & 557.57 & 131.42 & 310888.5 \\
\hline 19 & 89.51 & 116.05 & 26.62 & 13468.26 \\
\hline 19 & 21.59 & 30.33 & 6.96 & 920.01 \\
\hline
\end{tabular}

Table 8a. Descriptive statistics of Hagg Lake Data. 
Depth (m)

Secchi (m)

Ave_Extint_Coef.

Photic Depht $(m)$

$\mathrm{Ca}(\mathrm{mg} / \mathrm{l})$

$\mathrm{K}(\mathrm{mg} / \mathrm{l})$

$\mathrm{Mg}(\mathrm{mg} / \mathrm{l})$

$\mathrm{Na}(\mathrm{mg} / \mathrm{l})$

Tot-N (ug/l)

NO2-NO3 (ug/l)

$\mathrm{NH} 4$ (ug/l)

Tot-P (ug/l)

SRP (ug/l)

$\mathrm{SiO} 2(\mathrm{mg} / \mathrm{l})$

Ch-A (ug/l)

Alka (uEq/l)

Alka-CaCO3 (mg/L)

Temperature ( $d \mathrm{C}$ )

DO (mg/L)

$\mathrm{pH}$

Cond. (uS/cm)

Turbidity (NTU)

DO (\%)

RedoX (mv)

$\mathrm{DIC}(\mathrm{mgC} / \mathrm{L})$

TN:TP

TSI-Cha

TSI-S

TSI-TP

Si:TP

DIN(or SRN)

SRN:SRP

Hagg Lake

Range 95\% Conf.

Median Kurtosis Skewness Minimum Maximum Level

\begin{tabular}{|c|c|c|c|c|c|}
\hline 28.5 & -1.38 & -0.31 & 20 & 33.5 & 2.18 \\
\hline 2.1 & -0.5 & 0.46 & 0.4 & 5 & 0.65 \\
\hline 0.78 & 11.99 & 3.28 & 0.54 & 7.15 & 0.74 \\
\hline 5.88 & -0.88 & -0.49 & 0.64 & 8.56 & 1.13 \\
\hline 3.46 & -1.27 & -0.15 & 1.8 & 5.21 & 0.5 \\
\hline 0.18 & -0.54 & 0.34 & 0.09 & 0.34 & 0.03 \\
\hline 1.66 & 0.13 & 0.6 & 1.19 & 2.45 & 0.16 \\
\hline 4.99 & -1.39 & -0.18 & 2.79 & 6.52 & 0.6 \\
\hline 105.9 & 5.6 & 2.31 & 61.87 & 671.43 & 75.34 \\
\hline 10.95 & -0.7 & 1.05 & 0.13 & 329.47 & 65.64 \\
\hline 7.5 & 4.44 & 2.34 & 2.73 & 82.43 & 12.32 \\
\hline 15.4 & -0.51 & 0.39 & 4.04 & 33.5 & 4.19 \\
\hline 4.11 & 2.21 & 1.27 & 0.75 & 11.23 & 1.25 \\
\hline 13.03 & 2.35 & 0.53 & 6.53 & 21.11 & 1.54 \\
\hline 2.18 & 1.54 & 1.7 & 0.12 & 14.76 & 2.24 \\
\hline 499.2 & 0.39 & 0.96 & 378.8 & 820 & 58.31 \\
\hline 23.58 & 0.07 & 0.76 & 17.84 & 36.75 & 2.46 \\
\hline 17.87 & -1.32 & -0.39 & 5.77 & 25.28 & 3.19 \\
\hline 9.56 & -1.51 & 0.24 & 7.57 & 12.16 & 0.72 \\
\hline 7.54 & 0.03 & 0.64 & 6.88 & 8.55 & 0.23 \\
\hline 59.3 & -0.55 & -0.27 & 42.6 & 70.5 & 3.64 \\
\hline 18 & -0.84 & 0.59 & 2 & 57 & 7.92 \\
\hline 96.9 & 3.83 & 1.56 & 88.6 & 126.4 & 4.22 \\
\hline 386 & 0.65 & 0.86 & 349 & 449 & 12.44 \\
\hline 0.14 & -0.81 & 0.4 & 0.09 & 0.21 & 0.02 \\
\hline 10.25 & -0.35 & 0.77 & 3.23 & 28.02 & 3.78 \\
\hline 38.21 & 0.02 & -0.18 & 9.77 & 56.98 & 6.19 \\
\hline 49.3 & -0.34 & 0.71 & 36.78 & 73.22 & 4.98 \\
\hline 43.59 & -0.79 & -0.54 & 24.29 & 54.81 & 4.51 \\
\hline 911.44 & -0.18 & 0.71 & 194.93 & 2293.28 & 277.28 \\
\hline 20.22 & -0.07 & 1.23 & 1.13 & 332.2 & 55.94 \\
\hline 5.01 & 3.13 & 1.85 & 0.36 & 109.91 & 14.62 \\
\hline & & & & & \\
\hline & & & & \\
\hline & & & & \\
\hline
\end{tabular}

Table 8a. Descriptive statistics of Hagg Lake Data (cont.). 


\begin{tabular}{|c|c|c|c|c|c|c|}
\hline \multicolumn{7}{|c|}{ Hagg Lake Data - Epilimnion Data } \\
\hline Sample & HSO1 & HSO2 & HSO3 & $\mathrm{HSO} 4$ & HSO5 & HSO6 \\
\hline Date & $6 / 23 / 98$ & $7 / 7 / 98$ & $7 / 20 / 98$ & $8 / 4 / 98$ & $8 / 18 / 98$ & 9/1/98 \\
\hline Depth & 29.5 & 30.3 & 31.4 & 26.75 & 24.8 & 27.5 \\
\hline Secchi & 2.25 & 3 & 2.75 & 2 & 4.3 & 2 \\
\hline Ave_Extint_Coef. & 0.63714 & 0.58023 & 0.53782 & 0.59766 & 0.70957 & 0.71997 \\
\hline Photic Depht & 7.23 & 7.94 & 8.56 & 7.71 & 6.49 & 6.4 \\
\hline $\mathrm{Ca}$ & 4.332 & 3.428 & 5.207 & 4.76 & 4.7345 & 4.709 \\
\hline$K$ & 0.34 & 0.255 & 0.257 & 0.27 & 0.20508 & 0.14017 \\
\hline$M g$ & 1.523 & 1.662 & 1.523 & 1.81 & 1.91098 & 2.01196 \\
\hline $\mathrm{Na}$ & 5.954 & 3.05 & 4.865 & 4.942 & 5.31982 & 5.69763 \\
\hline Tot-N & 95.16 & 122.18 & 103.69 & 63.09 & $80^{*}$ & 65.58 \\
\hline NO2-NO3 & n.d. & n.d. & 0.13 & 0.71 & $1^{*}$ & 1.13 \\
\hline $\mathrm{NH} 4$ & 82.43 & 82.43 & 4.65 & 13.34 & 8 & n.d. \\
\hline Tot-P & n/a & 7.05 & 19.38 & 15.21 & $15^{*}$ & 10.97 \\
\hline$S R P$ & $n / a$ & 0.75 & 2.04 & 11.23 & 3 & 3.1 \\
\hline $\mathrm{SiO} 2$ & 10.06 & 10.31 & 13.44 & 11.21 & 13.335 & 15.46 \\
\hline$C h-A$ & 14.76 & 0.75 & 0.12 & 1.1 & 0.7 & 1.33 \\
\hline Alka-ueq/L & 499.2 & 512.8 & 557.86 & 507.5 & 820 & 663.82 \\
\hline Alka-CaCO3 $(\mathrm{mg} / \mathrm{L})$ & 24.96 & 25.64 & 27.893 & 25.375 & 27.48 & 33.191 \\
\hline Temperature & 20.13 & 22.57 & 23.92 & 25.28 & 23.51 & 23.58 \\
\hline$D O \_m g / L$ & 11.41 & 8.74 & 8.8 & 8.29 & 7.57 & 8.14 \\
\hline $\mathrm{pH}^{-}$ & 8.28 & 7.59 & 7.82 & 7.68 & 7.45 & 7.54 \\
\hline Cond_uS/cm & 57.4 & 60.3 & 61.3 & 61.2 & 60.2 & 61.7 \\
\hline NTU_Turb & 16 & 6 & 49 & 19 & 16 & 5 \\
\hline DO_\% & 126.4 & 102.9 & 104.8 & 102.3 & 89.2 & 96.9 \\
\hline RedoX_mv & 359 & 380 & 386 & 357 & 371 & 349 \\
\hline$D / C \_m g C / L$ & 0.11981 & 0.1282 & 0.13947 & 0.12688 & 0.2132 & 0.17259 \\
\hline$T N: T P$ & $n / a$ & 17.3305 & 5.35036 & 4.14793 & 5.33333 & 5.97812 \\
\hline TSI-Cha & 56.9776 & 27.7468 & 9.76854 & 31.504 & 27.0699 & 33.3667 \\
\hline$T S I-S$ & 48.3007 & 44.1504 & 45.4057 & 50 & 38.9566 & 50 \\
\hline TSI-TP & $\mathrm{n} / \mathrm{a}$ & 32.3266 & 46.9153 & 43.4199 & 43.2193 & 38.7053 \\
\hline Si:TP & $n / a$ & 1462.41 & 693.498 & 737.015 & 889 & 1409.3 \\
\hline$D I N$ (or $S R N)$ & 82.43 & 82.43 & 4.78 & 14.05 & 9 & 1.13 \\
\hline SRN:SRP & 3.01059 & 109.907 & 2.34314 & 1.25111 & 3 & 0.36452 \\
\hline
\end{tabular}

Table 8b. Hagg Lake Epilimnetic Data. 


\begin{tabular}{|c|c|c|c|c|c|c|}
\hline \multirow{3}{*}{$\begin{array}{l}\text { Sample } \\
\text { Date }\end{array}$} & \multicolumn{6}{|c|}{ Hagg Lake Data - Epilimnion Data (cont..) } \\
\hline & HSO7 & HSO8 & HSO9 & HS10 & HS11 & HS12 \\
\hline & 9/15/98 & $9 / 29 / 98$ & $10 / 13 / 98$ & $10 / 28 / 98$ & $11 / 10 / 98$ & $12 / 3 / 98$ \\
\hline Depth & 21.9 & 20 & 22.1 & 22.1 & 20.8 & 24.25 \\
\hline Secchi & 2.3 & 4.5 & 3 & 3.6 & 2.1 & 0.7 \\
\hline Ave_Extint_Coef. & 0.72142 & 0.74342 & 0.84978 & 0.94629 & 1.20154 & 2.61699 \\
\hline Photic Depht & 6.38 & 6.19 & 5.42 & 4.87 & 3.83 & 1.76 \\
\hline $\mathrm{Ca}$ & 3.76543 & 3.4621 & 3.4219 & 4.46408 & 4.73204 & 3.89304 \\
\hline K & 0.23409 & 0.22832 & 0.22137 & 0.17348 & 0.1822 & 0.14763 \\
\hline$M g$ & 2.17341 & 1.72947 & 1.62053 & 2.35663 & 2.45157 & 1.82149 \\
\hline $\mathrm{Na}$ & 6.51891 & 6.4511 & 6.50539 & 4.99 & 5.58 & 5.66 \\
\hline Tot-N & 73.15 & 61.87 & 114.61 & 183.56 & 312.15 & $140^{*}$ \\
\hline NO2-NO3 & n.d. & 1.28 & 0.47 & 6.29 & 15.61 & $277^{\star}$ \\
\hline NH4 & 5.3 & 15.84 & 10.3 & 5.29 & 4.61 & 35 \\
\hline Tot-P & 22.63 & 4.04 & 5.52 & 17.8 & 17.8 & $33.5^{*}$ \\
\hline$S R P$ & 1.93 & 2.45 & 2.15 & 5.28 & 4.39 & 4 \\
\hline $\mathrm{SiO} 2$ & 13.03 & 6.98 & 10.405 & 13.83 & 13.3 & $6.53^{*}$ \\
\hline$C h-A$ & 2.2 & 1.37 & 2.2 & 2.81 & 6.67 & 3.29 \\
\hline Alka-ueq/L & 735 & 469.44 & 471.56 & 600 & 640 & 467.36 \\
\hline Alka-CaCO3 (mg/L) & 36.75 & 23.472 & 23.578 & 30 & 32 & 23.368 \\
\hline Temperature & 22.31 & 20 & 17.16 & 14.54 & 12.02 & 8.91 \\
\hline DO_mg/L & 8.23 & 8.03 & 9.23 & 9.56 & 9.82 & 10.97 \\
\hline $\mathrm{pH}$ & 7.42 & 7.57 & 7.39 & 7.25 & 7.15 & 6.93 \\
\hline Cond_uS $/ \mathrm{cm}$ & 59.3 & 59.9 & 63.5 & 70.5 & 67.2 & 57.4 \\
\hline NTU_Turb & 40 & 18 & 9 & 18 & 17 & 35 \\
\hline DO_\% & 104.3 & 88.6 & 96.5 & 93.7 & 92.5 & 100 \\
\hline RedoX_mv & 414 & 368 & 366 & 379 & 390 & 396 \\
\hline$D I C \_m g C / L$ & 0.1911 & 0.12205 & 0.12732 & 0.168 & 0.1856 & 0.15657 \\
\hline$T N: T P$ & 3.23243 & 15.3144 & 20.7627 & 10.3124 & 17.5365 & 4.1791 \\
\hline TSI-Cha & 38.304 & 33.6574 & 38.304 & 40.7049 & 49.1853 & 42.252 \\
\hline TSI-S & 47.9837 & 38.3007 & 44.1504 & 41.52 & 49.2961 & 65.1457 \\
\hline TSI-TP & 49.152 & 24.2939 & 28.7971 & 45.6884 & 45.6884 & 54.8113 \\
\hline Si:TP & 575.784 & 1727.72 & 1884.96 & 776.966 & 747.191 & 194.925 \\
\hline$D I N($ or $S R N)$ & 5.3 & 17.12 & 10.77 & 11.58 & 20.22 & 312 \\
\hline$S R N: S R P$ & 2.74611 & 6.98776 & 5.0093 & 2.19318 & 4.60592 & 78 \\
\hline
\end{tabular}

Table 8b. Hagg Lake Epilimnetic Data (Cont.). 


\begin{tabular}{|c|c|c|c|c|c|c|c|}
\hline \multicolumn{8}{|c|}{ Hagg Lake Data - Epilimnion Data (cont..) } \\
\hline $\begin{array}{l}\text { Sample } \\
\text { Date }\end{array}$ & $\begin{array}{c}\text { HS13 } \\
1 / 19 / 99\end{array}$ & $\begin{array}{c}\text { HS14 } \\
2 / 17 / 99\end{array}$ & $\begin{array}{c}\text { HS15 } \\
3 / 16 / 99\end{array}$ & $\begin{array}{c}\text { HS16 } \\
4 / 14 / 99\end{array}$ & $\begin{array}{c}\text { HS17 } \\
5 / 12 / 99\end{array}$ & $\begin{array}{c}\text { HS18 } \\
5 / 26 / 99\end{array}$ & $\begin{array}{c}\text { HS19 } \\
6 / 16 / 99\end{array}$ \\
\hline Depth & 28.5 & 29.3 & 31.55 & 33.2 & 33.5 & 31.7 & 32.45 \\
\hline Secchi & 0.75 & 0.7 & 0.4 & 0.9 & 1.75 & 2 & 5 \\
\hline Ave_Extint_Coef. & 2.51592 & 2.01307 & 7.14989 & 1.44312 & 1.06641 & 0.78313 & 0.62801 \\
\hline Photic Depht & 1.83 & 2.29 & 0.64 & 3.19 & 4.32 & 5.88 & 7.33 \\
\hline $\mathrm{Ca}$ & 3.37 & 1.79863 & 2.15515 & 2.34923 & 2.42749 & 2.63127 & 2.47388 \\
\hline$K$ & 0.166 & 0.26312 & 0.14183 & 0.1006 & 0.12299 & 0.11362 & 0.091 \\
\hline$M g$ & 1.68 & 1.27725 & 1.18978 & 1.54574 & 1.63889 & 1.26998 & 1.60846 \\
\hline $\mathrm{Na}$ & 5.09 & 2.78944 & 3.26136 & 3.69675 & 3.59757 & 3.56891 & 3.3204 \\
\hline Tot-N & 208.19 & 222.4 & 671.43 & 436.5 & 105.9 & 65.97 & 69.21 \\
\hline NO2-NO3 & 329.47 & 268.58 & 241.55 & 169.71 & 53.38 & 5.78 & 15.78 \\
\hline NH4 & 2.73 & 5.81 & 6.99 & 4.62 & 9 & 11.54 & 4.86 \\
\hline Tot-P & 26.98 & 21.83 & 26.14 & 15.58 & 7.33 & 4.91 & 11.04 \\
\hline$S R P$ & 7.22 & 6.01 & 7.29 & 4.57 & 4.22 & 4.65 & 2.45 \\
\hline $\mathrm{SiO} 2$ & 14.6 & 21.11 & 13.98 & 14.55 & 12.14 & 11.26 & 11.62 \\
\hline$C h-A$ & 0.56 & 0.19 & 2.18 & 13.1 & 12.84 & 2.53 & 1.1 \\
\hline Alka-ueq/L & 421.1 & 606.1 & 455 & 383.68 & 378.8 & 425.2 & 428 \\
\hline Alka-CaCO3 (n & 21.105 & 17.842 & 22.75 & 19.184 & 18.94 & 21.26 & 21.4 \\
\hline Temperature & 6.03 & 5.77 & 7.11 & 10.64 & 13.02 & 17.87 & 20.73 \\
\hline$D O \_m g / L$ & 11.4 & 11.73 & 11.6 & 12.16 & 11.22 & 9.59 & 8.67 \\
\hline $\mathrm{pH}^{-}$ & 6.88 & 6.91 & 7.03 & 8.31 & 8.55 & 7.72 & 7.54 \\
\hline Cond_uS $/ \mathrm{cm}$ & 49.4 & 45.3 & 42.6 & 46.3 & 51 & 52.5 & 51.5 \\
\hline NTU_Turb & 45 & 39 & 57 & 35 & 8 & 16 & 2 \\
\hline$D O_{-} \%$ & 91.8 & 93.7 & 95.9 & 109.4 & 106.5 & 101.1 & 96.7 \\
\hline $\operatorname{Red} \bar{o} X \_m v$ & 407 & 449 & 433 & 387 & 393 & 368 & 398 \\
\hline$D / C \_m \bar{g} C / L$ & 0.15581 & 0.20607 & 0.14333 & 0.09208 & 0.0947 & 0.1063 & 0.11128 \\
\hline$T N: \bar{T} P$ & 7.71646 & 10.1878 & 25.6859 & 28.0167 & 14.4475 & 13.4358 & 6.26902 \\
\hline TSI-Cha & 24.8808 & 14.2767 & 38.2145 & 55.8072 & 55.6105 & 39.6752 & 31.504 \\
\hline TSI-S & 64.1504 & 65.1457 & 73.2193 & 61.52 & 51.9265 & 50 & 36.7807 \\
\hline TSI-TP & 51.6886 & 48.6328 & 51.2322 & 43.7666 & 32.8885 & 27.1076 & 38.7971 \\
\hline Si:TP & 541.142 & 967.018 & 534.813 & 933.89 & 1656.21 & 2293.28 & 1052.54 \\
\hline DIN(or SRN) & 332.2 & 274.39 & 248.54 & 174.33 & 62.38 & 17.32 & 20.64 \\
\hline SRN:SRP & 46.0111 & 45.6556 & 34.0933 & 38.1466 & 14.782 & 3.72473 & 8.42449 \\
\hline
\end{tabular}

Table 8b. Hagg Lake Epilimnetic Data (Cont.). 
Depth (m)

Secchi $(m)$

Ave_Extint_Coef.

Photic Depht (m)

$\mathrm{Ca}(\mathrm{mg} / \mathrm{l})$

$\mathrm{K}(\mathrm{mg} / \mathrm{l})$

$\mathrm{Mg}(\mathrm{mg} / \mathrm{l})$

$\mathrm{Na}(\mathrm{mg} / \mathrm{l})$

Tot-N (ug/l)

NO2-NO3 (ug/l)

$\mathrm{NH} 4$ (ug/l)

Tot-P (ug/l)

SRP (ug/l)

$\mathrm{SiO} 2(\mathrm{mg} / \mathrm{l})$

Ch-A (ug/l)

Alka (uEq/l)

Alka-CaCO3 (mg/L)

Temperature (d C)

DO (mg/L)

$\mathrm{pH}$

Cond. (uS/cm)

Turbidity (NTU)

DO (\%)

RedoX (mv)

DIC (mgC/L)

TN:TP

TSI-Cha

TSI-S

TSI-TP

Si:TP

DIN(or SRN)

SRN:SRP
Barney Reservoir

Standard Standard Sample Mean Deviation Error Variance

\begin{tabular}{|c|c|c|c|c|}
\hline$\pi$ & Mean & Deviation & Error & variance \\
\hline 19 & 18.11 & 5.99 & 1.37 & 35.89 \\
\hline 19 & 3.14 & 1.08 & 0.25 & 1.16 \\
\hline 19 & 1.03 & 0.3 & 0.07 & 0.09 \\
\hline 19 & 4.85 & 1.44 & 0.33 & 2.07 \\
\hline 19 & 2.94 & 0.91 & 0.21 & 0.83 \\
\hline 19 & 0.21 & 0.12 & 0.03 & 0.01 \\
\hline 19 & 1.39 & 0.37 & 0.08 & 0.14 \\
\hline 19 & 4.44 & 1.41 & 0.32 & 1.98 \\
\hline 19 & 161.75 & 271.55 & 62.3 & 73740.35 \\
\hline 17 & 48.66 & 53.34 & 12.94 & 2845.43 \\
\hline 14 & 9.71 & 7.9 & 2.11 & 62.4 \\
\hline 18 & 11.24 & 5.95 & 1.4 & 35.37 \\
\hline 18 & 2.4 & 1.12 & 0.26 & 1.25 \\
\hline 19 & 12.47 & 2.88 & 0.66 & 8.32 \\
\hline 19 & 2.18 & 1.01 & 0.23 & 1.02 \\
\hline 19 & 441.09 & 130.64 & 29.97 & 17066.01 \\
\hline 19 & 22.32 & 6.51 & 1.49 & 42.41 \\
\hline 19 & 13.91 & 6.86 & 1.57 & 47.1 \\
\hline 19 & 9.52 & 1.8 & 0.41 & 3.23 \\
\hline 19 & 7.03 & 0.23 & 0.05 & 0.05 \\
\hline 19 & 48.43 & 9.47 & 2.17 & 89.65 \\
\hline 19 & 17.11 & 7.06 & 1.62 & 49.88 \\
\hline 19 & 91.29 & 4.73 & 1.08 & 22.33 \\
\hline 19 & 400.84 & 21.5 & 4.93 & 462.36 \\
\hline 19 & 0.14 & 0.03 & 0.01 & 0 \\
\hline 18 & 14.68 & 14.64 & 3.45 & 214.3 \\
\hline 19 & 37.06 & 5.18 & 1.19 & 26.81 \\
\hline 19 & 44.28 & 4.91 & 1.13 & 24.1 \\
\hline 19 & 38.24 & 10.39 & 2.38 & 107.99 \\
\hline 18 & 1513.07 & 1211.69 & 285.6 & 1468192 \\
\hline 19 & 52.84 & 56.29 & 12.91 & 3168.68 \\
\hline 19 & 19.98 & 18.92 & 4.34 & 357.98 \\
\hline
\end{tabular}

Table 9a. Descriptive statistics of Barney Reservoir Data 
Barney Reservoir

Range $\quad 95 \%$ Conf.

Depth (m)

Secchi (m)

Ave_Extint_Coef.

Photic Depht (m)

$\mathrm{Ca}(\mathrm{mg} / \mathrm{l})$

$\mathrm{K}(\mathrm{mg} / \mathrm{l})$

$\mathrm{Mg}(\mathrm{mg} / \mathrm{l})$

$\mathrm{Na}(\mathrm{mg} / \mathrm{l})$

Tot-N (ug/l)

NO2-NO3 (ug/l)

$\mathrm{NH} 4$ (ug/)

Tot-P (ug/l)

SRP (ug/l)

$\mathrm{SiO} 2(\mathrm{mg} / \mathrm{l})$

Ch-A (ug/l)

Alka (uEq/l)

Alka-CaCO3 (mg/L)

Temperature (d C)

DO (mg/L)

$\mathrm{pH}$

Cond. (uS/cm)

Turbidity (NTU)

DO (\%)

RedoX (mv)

$\mathrm{DIC}(\mathrm{mgC/L})$

TN:TP

TSI-Cha

TSI-S

TSI-TP

Si:TP

DIN(or SRN)

SRN:SRP

Median Kurtosis Skewness Minimum Maximum Level

\begin{tabular}{|c|c|c|c|c|c|}
\hline 20.2 & -1.51 & -0.22 & 9.8 & 27.55 & 2.89 \\
\hline 2.8 & -1.32 & 0.46 & 1.75 & 4.9 & 0.52 \\
\hline 1.07 & -1.11 & 0.26 & 0.59 & 1.61 & 0.14 \\
\hline 4.29 & -0.83 & 0.48 & 2.86 & 7.76 & 0.69 \\
\hline 2.7 & -0.41 & 0.5 & 1.64 & 4.98 & 0.44 \\
\hline 0.18 & -0.31 & 0.67 & 0.06 & 0.46 & 0.06 \\
\hline 1.36 & -0.53 & -0.04 & 0.65 & 1.97 & 0.18 \\
\hline 4.29 & -1.55 & 0.25 & 2.46 & 6.55 & 0.68 \\
\hline 91.03 & 16.45 & 3.95 & 15.68 & 1249.71 & 130.88 \\
\hline 25.96 & 0.26 & 1.01 & 0.37 & 174.97 & 27.43 \\
\hline 7.04 & -0.63 & 0.87 & 1.62 & 25.23 & 4.56 \\
\hline 10.59 & 0.08 & 0.68 & 2.81 & 23.77 & 2.96 \\
\hline 1.92 & 0.8 & 1.31 & 1.32 & 5.01 & 0.56 \\
\hline 12.83 & 2.3 & -1.24 & 4.32 & 16.43 & 1.39 \\
\hline 2.14 & -0.13 & 0.36 & 0.61 & 4.53 & 0.49 \\
\hline 389.44 & 0.03 & 0.74 & 256.84 & 740 & 62.97 \\
\hline 23.16 & -0.07 & 0.62 & 12.84 & 37 & 3.14 \\
\hline 13.82 & -1.17 & -0.02 & 3.5 & 26.11 & 3.31 \\
\hline 9.16 & -0.67 & 0.56 & 7.35 & 13.33 & 0.87 \\
\hline 7.02 & -0.77 & 0.36 & 6.68 & 7.48 & 0.11 \\
\hline 51.1 & -1.4 & -0.43 & 33.1 & 60.3 & 4.56 \\
\hline 18 & -0.54 & -0.46 & 4 & 28 & 3.4 \\
\hline 90.1 & 0.09 & 0.43 & 82.7 & 101.7 & 2.28 \\
\hline 404 & -0.73 & 0.01 & 364 & 440 & 10.36 \\
\hline 0.14 & -0.04 & 0.74 & 0.1 & 0.21 & 0.02 \\
\hline 10.76 & 5.16 & 2.16 & 2.03 & 60.58 & 7.28 \\
\hline 38.03 & -0.34 & -0.6 & 25.72 & 45.39 & 2.5 \\
\hline 45.15 & -1.39 & -0.15 & 37.07 & 51.93 & 2.37 \\
\hline 38.74 & 1.07 & 0.18 & 19.06 & 63.11 & 5.01 \\
\hline 1160.65 & 5.72 & 2.43 & 567.1 & 5267.8 & 602.56 \\
\hline 20.45 & 0.29 & 1.07 & 0.37 & 189.13 & 27.13 \\
\hline 15.49 & -1.54 & 0.44 & 0.21 & 49.88 & 9.12 \\
\hline & & & & & \\
\hline
\end{tabular}

Table 9a. Descriptive statistics of Barney Reservoir Data (cont.). 
Barney Reservoir Data - Epilimnion Data

\begin{tabular}{|c|c|c|c|c|c|c|}
\hline $\begin{array}{l}\text { Sample } \\
\text { Date }\end{array}$ & $\begin{array}{l}\text { BS01 } \\
6 / 30 / 98\end{array}$ & $\begin{array}{l}\text { BSO2 } \\
7 / 14 / 98\end{array}$ & $\begin{array}{l}\text { BSO3 } \\
7 / 28 / 98\end{array}$ & $\begin{array}{l}\text { BSO4 } \\
8 / 11 / 98\end{array}$ & $\begin{array}{l}\text { BSO5 } \\
8 / 25 / 98\end{array}$ & $\begin{array}{l}\text { BSO6 } \\
9 / 8 / 98\end{array}$ \\
\hline Depth & 21.23 & 22.6 & 20 & 17.2 & 13.5 & 11.75 \\
\hline Secchi & 4.75 & 3.25 & 4.75 & 3.5 & 2.75 & 2.9 \\
\hline Ave_Extint_Coef. & 0.63563 & 0.81773 & 0.75711 & 0.83584 & 1.11684 & 1.19131 \\
\hline Photic Depht & 7.25 & 5.63 & 6.08 & 5.51 & 4.12 & 3.87 \\
\hline $\mathrm{Ca}$ & 3.461 & 2.641 & 4.98 & 3.877 & 2.7015 & 3.9779 \\
\hline$K$ & 0.436 & 0.296 & 0.46 & 0.371 & 0.2855 & 0.17322 \\
\hline$M g$ & 1.359 & 1.215 & 1.784 & 1.441 & 1.541 & 1.91505 \\
\hline $\mathrm{Na}$ & 5.975 & 2.91 & 3.33 & 4.915 & 3.602 & 5.64944 \\
\hline Tot-N & 44.12 & 93.49 & 130 & 87.57 & 91.03 & 117.36 \\
\hline NO2-NO3 & n.d. & n.d. & 1 & 9.32 & 87.05 & 2.33 \\
\hline NH4 & n.d. & n.d. & 7 & 8 & 4.75 & n.d. \\
\hline Tot-P & $\mathrm{n} / \mathrm{a}$ & 9.85 & 11 & 23.77 & 2.95 & 11.59 \\
\hline$S R P$ & $n / a$ & 1.32 & 1.51 & 1.7 & 2.01 & 5.01 \\
\hline $\mathrm{SiO} 2$ & 11.27 & 12.02 & 12.75 & 13.48 & 15.54 & 16.43 \\
\hline$C h-A$ & 1.28 & 1.7 & 1.19 & 1.8 & 2.9 & 4.53 \\
\hline Alka-ueq/ & 374.25 & 503.14 & 532 & 740 & 660 & 602.5 \\
\hline Alka-CaCO3 $(\mathrm{mg} / \mathrm{L})$ & 18.59 & 25.155 & 26.76 & 37 & 33 & 30.125 \\
\hline Temperature & 20.66 & 19.73 & 26.11 & 22.66 & 20.21 & 20.1 \\
\hline$D O \_m g / L$ & 8.55 & 7.69 & 7.37 & 7.35 & 7.88 & 8.1 \\
\hline$p H$ & 6.86 & 7.15 & 7.39 & 7.11 & 7.05 & 7.32 \\
\hline Cond_uS $/ \mathrm{cm}$ & 49.3 & 51.1 & 54.8 & 55.4 & 55.4 & 56.1 \\
\hline NTU_Turb & 21 & 15 & 17 & 18 & 28 & 12 \\
\hline DO_\% & 96 & 88.7 & 91.4 & 85.1 & 97 & 89.9 \\
\hline $\operatorname{Re} \bar{d} o X \_m v$ & 402 & 411 & 418 & 364 & 381 & 376 \\
\hline$D / C \_m \bar{g} C / L$ & 0.1235 & 0.14591 & 0.13832 & 0.2146 & 0.198 & 0.16268 \\
\hline$T N: \bar{T} P$ & $\mathrm{n} / \mathrm{a}$ & 9.49137 & 11.8182 & 3.68406 & 30.8576 & 10.126 \\
\hline TSI-Cha & 32.9908 & 35.7747 & 32.2756 & 36.3354 & 41.0142 & 45.3897 \\
\hline TSI-S & 37.5207 & 42.9956 & 37.5207 & 41.9265 & 45.4057 & 44.6395 \\
\hline TSI-TP & 63.1131 & 37.1516 & 38.7447 & 49.8611 & 19.7575 & 39.4985 \\
\hline Si:TP & n/a & 1220.3 & 1159.09 & 567.101 & 5267.8 & 1417.6 \\
\hline DIN(or SRN) & 20.45 & 20.45 & 8 & 17.32 & 91.8 & 2.33 \\
\hline SRN:SRP & 0.75184 & 15.4924 & 0.44444 & 10.1882 & 45.6716 & 0.46507 \\
\hline
\end{tabular}

Table 9b. Barney Reservoir Epilimnetic Data 


\begin{tabular}{|c|c|c|c|c|c|c|c|}
\hline \multirow{3}{*}{$\begin{array}{l}\text { Sample } \\
\text { Date }\end{array}$} & \multicolumn{7}{|c|}{ Barney Reservoir Data - Epilimnion Data (cont.) } \\
\hline & BSO7 & BSO8 & BSO9 & $B S 10$ & $B S 11$ & $B S 12$ & BS13 \\
\hline & $22 / 98$ & $10 / 6 / 98$ & $10 / 20 / 98$ & $11 / 3 / 98$ & $11 / 17 / 98$ & $12 / 10 / 98$ & $1 / 12 / 99$ \\
\hline Depth & 0.9 & 9.8 & 10.6 & 10.3 & 10.4 & 20.2 & 24.7 \\
\hline Secc & 2.2 & 2 & 1.75 & 2.5 & 2.8 & 2.25 & 2 \\
\hline Ave & 60809 & 1.3846 & 1.39279 & 1.276 & 1.35273 & 1.07404 & 1.28052 \\
\hline Phot & 2.86 & 3.3 & 3.31 & 3.61 & 3.4 & 4.29 & 3.6 \\
\hline $\mathrm{Ca}$ & 3.21091 & 3.24912 & 3.02682 & 3.98135 & 3.94899 & 2.51998 & 2.4 \\
\hline$K$ & & & 0.24744 & 0.17985 & 0.17094 & 0.17227 & 0.131 \\
\hline$M g$ & 54 & 1.52248 & 1.52104 & 1.97219 & 1.95 & 1.24177 & 1.17 \\
\hline $\mathrm{Na}$ & & 6.54775 & 6.48294 & 5.31 & 5.9 & 4.57 & 4.29 \\
\hline & .46 & 97.41 & 145.65 & 176.85 & & 81.81 & 79.88 \\
\hline & & & 58 & 67.1 & & 174.97 & 124.84 \\
\hline $\mathrm{NH}$ & & & 20.8 & 14.13 & & 14.16 & 7.07 \\
\hline Tot & .18 & 6.27 & 8.5 & 14.17 & & 11.59 & 9.98 \\
\hline & & & 1.85 & 3.79 & & 68 & 3.18 \\
\hline & & & 8.6 & 15.39 & & 13.47 & 12.83 \\
\hline & & & & & & & 1.9 \\
\hline & 9.44 & 514.4 & 463.2 & 471.47 & 500 & 311.56 & 290.52 \\
\hline & & & 23.16 & 23.55 & 25 & 15.578 & 14.526 \\
\hline & 18. & & 2.4 & 0.33 & & 08 & 3.94 \\
\hline$D$ & 7. & 8.88 & 9.4 & 9.75 & & 12.11 & 13.33 \\
\hline$p t$ & 6.94 & 7.29 & 7.04 & 6.87 & 6.92 & 6.69 & 6.86 \\
\hline & 55.3 & 58.4 & 60.3 & 58.8 & 57.2 & 38.5 & 34.8 \\
\hline NT & 20 & 19 & 25 & 18 & 6 & 26 & 25 \\
\hline & 82. & & 87.4 & 86.8 & & 98.3 & 101.7 \\
\hline & 37 & 37 & 414 & 401 & 39 & 407 & 404 \\
\hline$D / C \_m g C /$ & 0.12267 & 0.14403 & 0.14359 & 0.16501 & 0.1675 & 0.12462 & 0.10895 \\
\hline & & & 17.1353 & 12.4806 & & 7.05867 & 8.0040 \\
\hline & & 41.541 & 41.5089 & 41.048 & & 25.7198 & 36.865 \\
\hline & & 50 & 51.9265 & 46.7807 & 45.1457 & 48.3007 & 50 \\
\hline & 1967 & 30.635 & 35.025 & 42.3981 & 47.8171 & 39.4985 & 37.3408 \\
\hline Si:TP & 698.772 & 688.995 & 1011.76 & 1086.1 & 743.577 & 1162.21 & 1285.57 \\
\hline DIN(ors & 9.63 & 14.36 & 78.8 & 81.23 & 144.66 & 189.13 & 131.91 \\
\hline$S R N: S R P$ & 5.90798 & 5.86122 & 42.5946 & 21.4327 & 49.8828 & 40.4124 & 41.4811 \\
\hline
\end{tabular}

Table 9b. Barney Reservoir Epilimnetic Data (Cont.). 


\begin{tabular}{|c|c|c|c|c|c|c|}
\hline \multirow{3}{*}{$\begin{array}{l}\text { Sample } \\
\text { Date }\end{array}$} & \multicolumn{6}{|c|}{ Barney Reservoir Data - Epilimnion Data (cont.) } \\
\hline & $B S 14$ & $B S 15$ & $B S 16$ & $B S 17$ & $B S 18$ & $B S 19$ \\
\hline & $2 / 23 / 99$ & $3 / 23 / 99$ & $4 / 21 / 99$ & $5 / 19 / 99$ & $6 / 7 / 99$ & $7 / 7 / 99$ \\
\hline Depth & 27.55 & 25.3 & 21.3 & 23.1 & 22.6 & 21 \\
\hline Secchi & 2.05 & 2.55 & 4.9 & 4 & 4.4 & 4.4 \\
\hline Ave_Extint_Coef. & 1.08318 & 0.88652 & 0.79418 & 0.72471 & 0.7695 & 0.59334 \\
\hline Photic Depht & 4.25 & 5.19 & 5.8 & 6.35 & 5.98 & 7.76 \\
\hline $\mathrm{Ca}$ & 1.64248 & 1.78022 & 1.86245 & 2.07206 & 2.30139 & 2.31274 \\
\hline K & 0.18336 & 0.07333 & 0.06198 & 0.09533 & 0.06988 & 0.11135 \\
\hline$M g$ & 0.64735 & 0.92065 & 1.24142 & 1.24573 & 1.04433 & 0.98637 \\
\hline $\mathrm{Na}$ & 2.45782 & 3.02319 & 2.94724 & 3.57551 & 3.29347 & 3.18156 \\
\hline Tot-N & 57.48 & 256.32 & 237.24 & 31.99 & 15.68 & 23.2 \\
\hline NO2-NO3 & 71.78 & 60.74 & 25.96 & 1.44 & 1.59 & 0.37 \\
\hline $\mathrm{NH} 4$ & 3.79 & 20.82 & 3.36 & 2.41 & 1.62 & n.d. \\
\hline Tot-P & 10.18 & 7.11 & 14.58 & 2.81 & 4.64 & 11.44 \\
\hline$S R P$ & 2.77 & 1.71 & 1.5 & 1.98 & 1.4 & 1.74 \\
\hline $\mathrm{SiO} 2$ & 13.93 & 11.91 & 13.36 & 11.26 & 9.36 & 10.78 \\
\hline$C h-A$ & 1.04 & 2.49 & 2.14 & 2.98 & 0.86 & 1.29 \\
\hline Alka-ueq/L & 256.84 & 380 & 309.46 & 345.2 & 360 & 376.8 \\
\hline Alka-CaCO3 $(\mathrm{mg} / \mathrm{L})$ & 12.842 & 24 & 15.473 & 17.26 & 18 & 18.84 \\
\hline Temperature & 3.5 & 5.67 & 8.88 & 11.2 & 13.82 & 17.08 \\
\hline DO_mg/L & 11.84 & 11.37 & 10.89 & 10.34 & 9.16 & 8.67 \\
\hline$p H^{-}$ & 6.76 & 6.68 & 6.87 & 7.02 & 7.24 & 7.48 \\
\hline Cond uS/cm & 33.5 & 33.1 & 37.6 & 41.7 & 44.3 & 44.5 \\
\hline NTU_Turb & 11 & 22 & 5 & 4 & 19 & 14 \\
\hline DO_\% & 89.2 & 90.6 & 93.9 & 94.2 & 88.6 & 89.9 \\
\hline$R e \bar{d} o X \_m v$ & 440 & 427 & 434 & 409 & 406 & 382 \\
\hline$D I C \_m \bar{g} C / L$ & 0.1053 & 0.1672 & 0.11295 & 0.10701 & 0.1008 & 0.09797 \\
\hline$T N: \bar{T} P$ & 5.64637 & 36.0506 & 16.2716 & 11.3843 & 3.37931 & 2.02797 \\
\hline TSI-Cha & 30.9538 & 39.5188 & 38.0328 & 41.2811 & 29.0894 & 33.0671 \\
\hline TSI-S & 49.6438 & 46.495 & 37.0722 & 40 & 38.625 & 38.625 \\
\hline TSI-TP & 37.627 & 32.4489 & 42.8096 & 19.0561 & 26.2916 & 39.3105 \\
\hline Si:TP & 1368.37 & 1675.11 & 916.324 & 4007.12 & 2017.24 & 942.308 \\
\hline DIN(or SRN) & 75.57 & 81.56 & 29.32 & 3.85 & 3.21 & 0.37 \\
\hline SRN:SRP & 27.2816 & 47.6959 & 19.5467 & 1.94444 & 2.29286 & 0.21264 \\
\hline
\end{tabular}

Table 9b. Barney Reservoir Epilimnetic Data (Cont.). 


\begin{tabular}{c|ccc}
$\begin{array}{l}\text { Sample } \\
\text { Date }\end{array}$ & BSO3 & HSO5 & HS12 \\
\multicolumn{1}{c|}{ SO4 $\mathrm{mg} / \mathrm{L}$} & 0.25 & 0.69 & 0.73 \\
$\mathrm{Cl} \mathrm{mg} / \mathrm{L}$ & 2.59 & 2.41 & 2.48 \\
\multicolumn{2}{c}{ Data from CCA Laboratory. (Cameron Jones, chemist). }
\end{tabular}

Table 10. Anion Data from CCAL (Cameron Jones, 1998) 


\section{REFERENCES}

Ameel, J. J. Ameel, Axler, R. P., Owen, C. J. 1995. Persulfate digestion for determination of total nitrogen and phosphorus in low-nutrient waters. Am. Env. Lab. 5(6), 4 pages.

American Public Health Association. 1995. Standard Methods for the Examination of Water and Wastewater. 19th Ed. American Public Health Association, Washington, DC. 1555 pp.

Axler, R. P., Owen, C. J. 1994. Measuring chlorophyll and phaeophytin: Whom should you believe? Lake and Reserv. Manage. 8(2):143-151.

Beaty R. D., Kerber, J. D. 1993. Concepts, instrumentation and techniques in atomic adsorption spectrophotometry. The Perkin-Elmer Corp., Norwalk, Connecticut.

Cameron Jones, 1998. Cooperative Central Analytical Laboratory, sample collection, handling and preservation document. Personal communication.

Carlson, R. E. 1977. A trophic state index for lakes. Limnol. and Ocean. 22:361-369

Carpenter, K. D. 1994. Indicators of nutrient limited plankton growth in lakes near mount Saint Helens, WA. M.S. Thesis, Portland State University. $175 \mathrm{pp}$.

Contant, H. and Duthie, H.C. 1978. The phytoplankton of Lac St-Jean, Quebec. (Bibliotheca Phycologica, Band 40). J. Cramer-Strauss and Cramer GmbH, Hirsheberg II, Germany. 165 pp (30 Plates).

Corliss, John Ozro, 1979. The ciliated protozoa, characterization, classification and guide to the literature. 2nd. Ed., Pergamon Press Ltd., New York, New York. 455 pp. 
Honea, J. M. (1997). The periphyton community of a second order subalpine stream following salmon carcass decomposition: a potential facilitator of energy flow from adult to juvenile salmonids. Portland State University M.A. Thesis, 52pp.

Huber-Pestalotz, G., 1941. Das Phytoplankton des Süßwassers, sistematik und Biologie. Die Binnengewässer Limnologie und ihren Nachbargebieten, Band XVI, 2 Teil, Stuggart, Germany.

Johnson, D. M., Petersen, R. P., Lycan, R. D., Sweet, J. W., Neuhaus, M.E., Schaedel A. L. 1985. Atlas of Oregon Lakes. Oregon State University Press, Corvallis, Oregon.

Jones, M. N. 1984. Nitrate reduction by shaking with cadmium, alternative to cadmium columns. Water Res. 18(5):643-646.

Knutson, M. T. 1993. Modelling of flow and water quality in Henry Hagg Lake near Forest Grove, Oregon. M.S. Thesis, Portland State University. 146 pp.

Krammer, K. and Lange-Bertalot, H. 1991. Bacillariophyceae 1., Herausgegeben von $\mathrm{H}$. et al. Ed. Band 2/1. Süßwasserflora von Mitteleuropa. Gustav Fisher Verlag. Stuttgart, Germany.

Krammer, K. and Lange-Bertalot, H. 1991. Bacillariophyceae 2., Herausgegeben von $\mathrm{H}$. et al. Ed. Band 2/2. Süßwasserflora von Mitteleuropa. Gustav Fisher Verlag. Stuttgart, Germany.

Krammer, K. and Lange-Bertalot, H. 1991. Bacillariophyceae 3., Herausgegeben von $\mathrm{H}$. et al. Ed. Band 2/3. Süßwasserflora von Mitteleuropa. Gustav Fisher Verlag. Stuttgart, Germany.

Krammer, K. and Lange-Bertalot, H. 1991. Bacillariophyceae 4., Herausgegeben von $\mathrm{H}$. et al. Ed. Band 2/4. Süßwasserflora von Mitteleuropa. Gustav Fisher Verlag. Stuttgart, Germany.

Lewis, T.H. and Britton, M.E., 1971. The Algae of Illinois. Hafner Publishing Co., New York, N. Y.

Nauwerck, A. 1963. Die Beziehungen zwischen Zooplankton und Phytoplankton im See Erken. Symbol. Bot. Upsaliensis 17(5):1-163. 
Patrick, R. and Reimer, C. W., 1966. The Diatoms of the United States Exclusive of Alaska and Hawaii. Vol. I and II. Monographs of the Academy of Natural Sciences of Philadelphia. No. 13. Livingston Publishing Co. Philadelphia.

Pennak, R. W. 1989. Fresh-Water invertebrates of the United States: Protozoa to Mollusca. 3rd. Edition. Wiley and Sons, Pub. New York.

Prescott, G.W. 1978. How to Know the Freshwater Algae. 3rd. Edition. Wm. C. Brown Co. Publishers. Dubuque, Iowa, USA.

Prescott, G.W., 1962. Algae of the Western Great Lakes Area. Cranbrook Institute of Science, Bulletin No. 31., Reprint 1982 by Otto Koeltz Science Publishers. Koenigstein. W. Germany.

Reynolds, C.S. 1996. The plant life of the pelagic. Verh. Internat. Verein. Limnol. 26:97-113.

Reynolds, C. S. 1984. The ecology of Freshwater Phytoplankton. Cambridge University Press. Cambridge, Great Britain.

Ryder, R. A. 1978. Ecological heterogeneity between north-temperate reservoirs and glacial lakes systems due to different succession rates and cultural uses. Verh. Int. Verein. Limnol. 20:1568-1574.

Shannon C. E. and Weaver W. 1949. The mathematical theory of communication. The University of Illinois Press. Urbana, Illinois.

Smith, G.M., 1950. The Freshwater Algae of the United States. 2nd. Edition. McGraw-Hill Book Co. New York, N.Y., USA.

Stemberger, R. S. 1979. A Guide to Rotifers of the Laurentian Great Lakes. EPA-600/4-79-021. Environmental monitoring and support laboratory. U.S. Environmental Protection Agency. Cincinnati, Ohio, U.S. A. 
Stewart, A.R. 1980. Relationships between trout and invertebrate species as predators and the structure of the crustaceans and rotiferans plankton in Mountain Lakes (625-634). Herfoot, W.C. Editor. Evolution and Ecology of Zooplankton Communities, University Press of New England, New Hampshire, U.S.A.

Sommer U. 1993. Disturbance diversity relationships in two lakes of similar nutrient chemistry but contrasting disturbance regimes. Hydrobiologia 249: 59-65.

Sommer, U., Ed. 1989. Plankton Ecology: Succession in Plankton Communities. Springer -Verlag, New York.

Sommer, U., Maciej, G., Lampert, W. and Duncan, A. 1986. The PEG model of seasonal succession of planktonic events in fresh waters. Archiv.f. Hydrobiologie 106: 433-471

Tilman D. 1982. Resource Competition and Community Structure. Princeton University Press. Princeton, New Jersey. 296 pp.

Torke, B. G. 1974. An illustrated guide to the identification of the planktonic Crustacea of Lake Michigan with notes on their ecology. Special report no. 17. Center for great lakes studies, University of WisconsinMilwaukee, Wisconsin. U.S.A.

Thornton K.W., Kimmel B. L. and Payne F. E. Editors. 1990. Reservoir Limnology. Wiley and Sons Inc.: New York. 246 pp.

Thorp, J. H. and Covich, A. P. Ed. (1991) Ecology and Classification of North American Freshwater Invertebrates. Academic Press, Inc. San Diego, California.

U. S. Environmental Protection Agency (1979). Methods for chemical analysis of water and wastes. EPA-600/4-79-020. Cincinnati, Ohio.

Vinyard, W.C., 1979. Diatoms of North America. Mad River Press-Eureka Printing Co., Eureka, California. 
Walker, G. W., MacLeod, N. S. 1991. Geologic Map of Oregon. U. S. Geological Survey Publications.

Weber, C. I., 1971. A Guide to the Common Diatoms at Water Pollution Surveillance System Stations. U.S. Environmental Protection Agency, Cincinnati, Ohio.

West W. and West, G.S., 1971. A Monograph of the British Desmidaceae. Volumes I-IV. Johnson Reprint Co., New York, New York

Wetzel, R. G., Likens, G. E. 1991. Limnological Analysis, 2nd. Ed. Springer Verlag, New York. 391 pp. 


\section{APPENDIX A. LABORATORY PROCEDURES FOR WATER CHEMISTRY, CATIONS AND CHLOROPHYLL-A ANALYSIS.}

\section{Guidelines for the handling of samples (Jones, 1998):}

1. Rinse filters with at least $500 \mathrm{ml}$ of deionized water to remove manufacturing contaminants, and dry them for at least 48 hours in a $55^{\circ} \mathrm{C}$ oven. Use flat-edged filter paper forceps to avoid handling the papers and possibly puncturing the papers (Jones, 1998).

2. Filter samples as soon as possible after collection (in the field).

3. The general recommendation is that the best overall sample preservation technique is storage at sub-zero temperatures (USEPA, 1979).

4. If the time between collection and submission to the laboratory is greater than 24 hours, the filtered samples should be frozen and not allowed to thaw until it arrives at the laboratory. Unfiltered samples should be frozen until arrival at the laboratory. Leave at least $10 \%$ of the bottle volume as headspace to accommodate expansion of the sample.

5. An alternate method for preserving cation samples is to keep the filtered samples frozen until immediately prior to analysis. 


\section{Laboratory Procedures:}

The samples in this study were divided in filtered samples and unfiltered samples. Filtered samples were tested for nitrite+nitrate, ammonia, SRP, dissolved silica, dissolved magnesium, dissolved sodium, dissolved calcium and dissolved potassium analytes concentrations. Unfiltered samples were tested for alkalinity, total nitrogen and total phosphorus analytes concentrations.

The volume of the reagents used in these procedures is optimized for twelve samples and their standards. The procedures were adapted from Carpenter (1994), Jones (1984), Wetzel and Likens (1991) and Ameel et al. (1993). The water used in the chemical analysis was distilled water filtered again through a Barnstead ${ }^{\circledR}$ (Thermolyne) ion exchange filter assembly, model NANOpure II ${ }^{\circledast}$.

The acid wash was a $4 \%$ hydrochloric acid bath. The items to be cleaned were placed for at least 6 hours. They were rinsed afterward eight times with ultra pure deionized water, and set to dry upside down in a protected area.

The chemicals were of reagent grade quality. The individual reagents were prepared the same day of the analysis in acid washed, rinsed and dried volumetric flasks. The volumetric flasks were wrapped in foil and kept in a closed refrigerator until a few minutes before use. The glass pipettes, 
borosilicate vials and its caps, the reusable tips of micropipettes, and the stirrer bars were also acid washed, rinsed and dried.

The chlorophyll-a analysis was performed with a Turner Designs Fluorometer Model 10-005R (No.5564) calibrated for chlorophyll. A Milton Roy Spectronic ${ }^{\circledast} 401$ spectrophotometer, with a wavelength range of 325 to 900 nanometers $(\mathrm{nm})$ and equipped with a cell of $5 \mathrm{~cm}$ in length, was used for the nutrient analysis. Concentrations were determined from the plot of the absorbances of the standards versus their known concentrations (Wetzel and Likens, 1991).

The cations analysis was performed with an AAnalyzer $300^{\circledR}$ manufactured by the Perkin-Elmer Corporation, and utilizing the flame atomic adsorption technique. For the cations analysis, one blank and three standards were always used.

For the titrations and other tasks in the laboratory that required $\mathrm{pH}$ readings, an Orion ${ }^{\circledR}$ portable $\mathrm{pH} /$ Temperature/mV 290A meter was used. This meter was equipped with an Orion triode ${ }^{\circledR}$ electrode, with automatic temperature compensation. The shaker machine was a Lab-Line Orbit Shaker 3590 from Lab-Line Instruments Inc. 


\section{Total Nitrogen:}

Total nitrogen concentrations were determined after an alkaline potassium persulfate digestion (Carpenter, 1994); (Ameel et al., 1993) and followed by the cadmium reduction method (Jones, 1984).

Reagents:

A. -- Dissolve 0.722 grams of $\mathrm{KNO}_{3}$ (previously oven dried at $105^{\circ} \mathrm{C}$. for 24 hours) in $500 \mathrm{ml}$ of ultra pure deionized water and then dilute this to 1 liter using ultra pure deionized water, to produce a 100,000 $\mu \mathrm{g}$. N/L stock solution. Make a working solution of $1,000 \mu \mathrm{g}$. N/L by diluting the stock by a ratio of 1:100; from this make six different standard solutions with concentrations ranging from 2 to $200 \mu \mathrm{g} \mathrm{N} / \mathrm{L}$. Make an independent control blank.

B. -- Dissolve 20 grams of potassium persulfate in $250 \mathrm{ml}$ of ultra pure deionized water and then dilute this to $500 \mathrm{ml}$ using ultra pure deionized water to obtain a solution with a concentration of $0.148 \mathrm{M}$ C. -- Dissolve 12 grams of $\mathrm{NaOH}$ in $75 \mathrm{ml}$ of ultra pure deionized water and then dilute this to $100 \mathrm{ml}$ using ultra pure deionized water to obtain a $3 \mathrm{~N}$ concentration. Let it cool before using. 
Analytical Procedures:

Add $15 \mathrm{ml}$ of blank, standard or sample to an acid washed, rinsed and dried borosilicate screw-top vials $(40 \mathrm{ml})$ lined with a cap with a Teflon ${ }^{\circledR}$ liner; then add the following:

-- $5 \mathrm{ml}$ of potassium persulfate solution $(190 \mathrm{ml}$ will be needed for both total phosphorus and total nitrogen).

- $250 \mu \mathrm{L}$ of $\mathrm{NaOH}$ solution. Vortex or shake vigorously. Autoclave for 55 minutes at $121^{\circ} \mathrm{C}$. and 17 PSI, or boil for two hours. After the samples cool add:

$-250 \mu \mathrm{L}$ of the $\mathrm{NaOH}$ solution.

Finish with the cadmium reduction method outlined in the nitrite+nitrate nitrogen analytical procedure.

\section{Nitrate+Nitrite Nitrogen:}

Concentrations of nitrate+nitrite nitrogen were determined using the cadmium reduction method (Jones, 1984) described by Carpenter (1994). Reagents: 
A. --Dissolve 0.722 grams $\mathrm{KNO}_{3}$ (previously oven dried at $105^{\circ} \mathrm{C}$. for 24 hours) in $500 \mathrm{ml}$ of ultra pure deionized water and then dilute this to 1 liter using ultra pure deionized water, to produce a 100,000 $\mu \mathrm{g}$. N/L stock solution. Make a working solution of $1,000 \mu \mathrm{g}$. N/L by diluting the stock by a ratio of 1:100; from this make six different solutions with concentrations ranging from 2-200 $\mu \mathrm{g} \mathrm{N} / \mathrm{L}$. Make an independent control blank.

B. -- Add 37.4 grams $\mathrm{NH}_{4} \mathrm{Cl}$ to $800 \mathrm{ml}$ of ultra pure deionized water. Add some $\mathrm{NH}_{4} \mathrm{OH}$ until $\mathrm{pH}$ is equal to 8.5 units. Add ultra pure deionized water to this solution until the volume is equal to 1 liter.

C. -- In a beaker, dissolve 60 grams $\mathrm{CdSO}_{4}$ in $300 \mathrm{ml}$ of ultra pure deionized water. Put two or three bars or strips of zinc in the solution and allow them to sit for at least 12 Hours. Create a solution of equal parts of $12 \mathrm{~N} \mathrm{HCl}$ and ultra pure deionized water $(6 \mathrm{~N} \mathrm{HCl}$ or 1:1 ratio). After 12 hours have elapsed, remove the spongy cadmium adhered to the zinc and store the zinc bars after rinsing them. Rinse the spongy cadmium with the $6 \mathrm{~N} \mathrm{HCl}$ solution, for at least 10 minutes. Break the spongy cadmium up in pieces of \pm 0.1 grams, and wash them with ultra pure deionized water for at lest 10 times, or until the measured $\mathrm{pH}$ is greater than 5.0 units. D. -- Add $10 \mathrm{ml}$ of $85 \%$ phosphoric acid to $80 \mathrm{ml}$ ultra pure deionized water. To this solution add 1 gram of Sulfanilamide. After mixing the Sulfanilamide, add 0.1 grams of $\mathrm{N}-(1-\mathrm{Naphthyl})$ ethylenediamine 
dihydrochloride. Mix this solution well. Dilute to $100 \mathrm{ml}$ using ultra pure deionized water. This solution is photosensitive and must be stored in the dark in a foil wrapped beaker. Make this solution as needed.

Analytical Procedures:

Add $20 \mathrm{ml}$ of blank, standard or sample to an acid washed, rinsed and dried $50 \mathrm{ml}$ a screw-top test tube; then add the following:

$--4 \mathrm{ml}$ of the $\mathrm{NH}_{4} \mathrm{Cl}$ solution and vortex to mix.

-- 1 gram of spongy cadmium. Close the test tube and place it horizontally with the other test tubes in the shaker (running at 100 revolutions per minute) for 90 minutes.

Decant $20 \mathrm{ml}$ of this solution into a clean test tube, and add:

- Add $1 \mathrm{ml}$ of the phosphoric acid solution(D).

Incubate in the dark, at a constant temperature of $20^{\circ} \pm 5^{\circ} \mathrm{C}$., for 10 to 120 minutes. Read the sample in the Milton Roy Spectronic ${ }^{\circledR} 401$ spectrophotometer, set to a wavelength of $540 \mathrm{~nm}$ with a cell having a path length of $5 \mathrm{~cm}$. 


\section{Ammonium Nitrogen:}

Concentrations of ammonium nitrogen were determined using the phenol-hyplochlorite method outlined in Wetzel and Likens (1991) and described by Carpenter (1994).

Reagents:

A. --Dissolve 3.819 grams $\mathrm{NH}_{4} \mathrm{Cl}$ (Oven Dried at $105^{\circ} \mathrm{C}$ for 24 Hours) in 500 $\mathrm{ml}$ of ultra pure deionized water and then dilute this to 1 liter using ultra pure deionized water, to produce a solution of $1,000,000 \mu \mathrm{g} \mathrm{NH}-\mathrm{N} / \mathrm{L}$.

Make a working solution of $5,000 \mu \mathrm{g} . \mathrm{N} / \mathrm{L}$ by diluting the stock by a ratio of 1:200; from this make six different solutions with concentrations ranging from $10-400 \mu \mathrm{g} N / \mathrm{L}$. Make an independent control blank.

B. -- Dissolve 5 grams $\mathrm{Na}_{3} \mathrm{PO}_{4}$ in $250 \mathrm{ml}$ of ultra pure deionized water and then dilute this to 1 liter using ultra pure deionized water.

C. -- Dissolve 25 grams of phenol in $40 \mathrm{ml}$ of methanol. This solution can be stored refrigerated for up to 6 months.

D. -- Dissolve 27 grams of $\mathrm{NaOH}$ in $100 \mathrm{ml}$ of ultra pure deionized water. Let this solution cool.

Solution 1. -- Dissolve 0.01 grams of sodium nitroprusside in $7.5 \mathrm{ml}$ of the phenol solution (C). Add ultra pure deionized water to this solution until the volume is equal to $50 \mathrm{ml}$ This solution is photosensitive and must be stored in the dark, in a foil wrapped beaker. 
Solution 2. -- To $15 \mathrm{ml}$ of $\mathrm{NaOH}$ solution (D) add $15 \mathrm{ml}$ of sodium

hypochloride (or chlorine bleach of $5 \%$ chlorine). Add ultra pure deionized water to this solution until the volume equals to $50 \mathrm{ml}$ This solution is photosensitive and must be stored in the dark in a foil wrapped beaker. Analytical Procedures:

Add $25 \mathrm{ml}$ of blank, standard or sample to an acid washed, rinsed and dried $50 \mathrm{ml}$ a screw-top test tube; then add the following:

-- Add $1 \mathrm{ml}$ of the $\mathrm{Na}_{3} \mathrm{PO}_{4}$ solution and vortex to mix well.

-- Add $2.5 \mathrm{ml}$ of the solution 1 (phenol + sodium nitroprusside), and vortex to mix well.

-- Add $1.5 \mathrm{ml}$ of the solution $2(\mathrm{NaOH}$ and Chlorine), and vortex to mix well. Incubate in the dark, at a constant temperature for 1 to 24 hours. Read the sample in the Milton Roy Spectronic ${ }^{\circledR} 401$ spectrophotometer, set to a wavelength of $630 \mathrm{~nm}$ with a cell having a path length of $5 \mathrm{~cm}$.

\section{Total Phosphorus:}

Concentrations of total phosphorus were determined after the alkaline potassium persulfate digestion outlined by Ameel et. al. (1993) followed by the ascorbic acid method (Wetzel and Likens 1991); Carpenter (1994). Reagents: 


\section{A. -- Dissolve 0.2197 grams $\mathrm{KH}_{2} \mathrm{PO}_{4}$ (Oven Dried at $105^{\circ} \mathrm{C}$ for 24 Hours) plus}

$1 \mathrm{ml}$ of chloroform in $500 \mathrm{ml}$ of ultra pure deionized water and then dilute this to 1 liter using ultra pure deionized water, to produce a solution of $50,000 \mu \mathrm{g} \mathrm{P} / \mathrm{L}$. Make a working solution of $500 \mu \mathrm{g}$. P/L by diluting the stock by a ratio of $1: 100$, from this make six different solutions with concentrations ranging from 1-100 $\mu \mathrm{g} \mathrm{P} / \mathrm{L}$. Make an independent control blank.

B. -- Dissolve 20 grams of potassium persulfate in $250 \mathrm{ml}$ of ultra pure deionized water and then dilute this to $500 \mathrm{ml}$ using ultra pure deionized water to obtain a solution with a concentration of $0.148 \mathrm{M}$

C. -- Dissolve 12 grams of $\mathrm{NaOH}$ in ultra pure deionized water and dilute this to $100 \mathrm{ml}$ using ultra pure deionized water to obtain a $3 \mathrm{~N}$ concentration. Let it cool before using.

Analytical Procedures:

Add $15 \mathrm{ml}$ of blank, standard or sample to an acid washed, rinsed and dried borosilicate screw-top vials $(40 \mathrm{ml})$ lined with a Teflon liner; then add the following:

$-5 \mathrm{ml}$ of potassium persulfate solution.

-- $250 \mu \mathrm{L}$ of $\mathrm{NaOH}$ solution. Vortex or shake vigorously.

Autoclave for 55 minutes at $121^{\circ} \mathrm{C}$. and $17 \mathrm{PSI}$, or boil for two hours. After the samples cool add: 
$--250 \mu \mathrm{L}$ of the $\mathrm{NaOH}$ solution.

If necessary, refrigerate samples for up to 28 days. Finish analysis with the ascorbic acid method outlined in the soluble reactive phosphorus analytical procedure.

\section{Soluble Reactive Phosphorus:}

Concentrations of SRP were determined using the ascorbic acid method described in Wetzel and Likens (1991) and modified by Carpenter (1994).

Reagents:

A. -- Dissolve 0.2197 grams $\mathrm{KH}_{2} \mathrm{PO}_{4}$ (Oven Dried at $105^{\circ} \mathrm{C}$ for 24 Hours) plus $1 \mathrm{ml}$ of chloroform in $500 \mathrm{ml}$ of ultra pure deionized water and then dilute this to 1 liter using ultra pure deionized water, to produce a solution of $50,000 \mu \mathrm{g} P / \mathrm{L}$. Make a working solution of $500 \mu \mathrm{g} . \mathrm{P} / \mathrm{L}$ by diluting the stock by a ratio of 1:100, from this make six different solutions with concentrations ranging from 1-100 $\mu \mathrm{g} \mathrm{P} / \mathrm{L}$. Make an independent control blank. B. -- Dissolve 15 grams of ammonium (paramolybdate) molybdate in $250 \mathrm{ml}$ of ultra pure deionized water and then dilute this to $500 \mathrm{ml}$ using ultra pure deionized water. Store in the dark. The shelf life of this solution is of 2-3 months. 
C. -- Dilute $135 \mathrm{ml}$ of $\mathrm{H}_{2} \mathrm{SO}_{4}$ to 1 liter using ultra pure deionized water. Store in a stoppered glass bottle.

D. -- Dissolve 0.34 grams of potassium antimonyl-tartrate in $100 \mathrm{ml}$ of ultra pure deionized water and then dilute this to $250 \mathrm{ml}$ using ultra pure deionized water. Warm this solution if necessary, and store in a stoppered glass bottle.

E. -- Dilute 2.7 grams of L-ascorbic acid to $50 \mathrm{ml}$ using ultra pure deionized water.

Composite solution: Make this solution just before using it. This composite solution is photosensitive. Accordingly, it is kept in the dark, in an

Erlenmeyer flask with its mouth covered with parafilm. Mix this composite in the following order.

-- Add $50 \mathrm{ml}$ of the $\mathrm{H}_{2} \mathrm{SO}_{4}$ solution.

-- Add $10 \mathrm{ml}$ of the potassium antimonyl-tartrate solution.

-- Add $20 \mathrm{ml}$ of the ammonium (paramolybdate) molybdate solution.

-- Add $20 \mathrm{ml}$ of the L-ascorbic acid solution.

Analytical Procedures:

Add $20 \mathrm{ml}$ of blank, standard or sample to an acid washed, rinsed and dried $50 \mathrm{ml}$ a screw-top test tube; then add the following: 
-- Add $2 \mathrm{ml}$ of the composite solution, and vortex or shake well.

Incubate in the dark, at a constant temperature for 10 to 120 minutes.

Read the sample in the Milton Roy Spectronic ${ }^{\circledR} 401$ spectrophotometer, set to a wavelength of $880 \mathrm{~nm}$ with a cell having a path length of $5 \mathrm{~cm}$.

\section{Dissolved Silica}

The concentrations of silica were determined using the method described in Wetzel and Likens (1991) and by Carpenter (1994). If the silica analysis is made on thawed samples, then these samples should be allowed to stand for a period of time (1-7 days) to allow the silica to become reactive again (Wetzel and Likens, 1991).

Reagents:

A. -- Dissolve 1.765 grams of sodium silica pentahydrate (previously stabilized by placing in a dissector, for at least 3 hours) in 1 liter of ultra pure deionized water. Dilute $100 \mathrm{ml}$ of stock in 1 liter of ultra pure deionized water to produce a working solution of $50 \mathrm{mg} / \mathrm{L}$ of $\mathrm{SiO}_{2}$; from this make six different solutions with concentrations ranging from 2.5 to $20 \mathrm{mg} / \mathrm{L}$ of $\mathrm{SiO}_{2}$. Make an independent control blank.

B. -- Dilute $22 \mathrm{ml}$ of $\mathrm{HCl}$ to 1 liter $(1000 \mathrm{ml})$ using ultra pure deionized water. This will create a solution of a concentration of $0.25 \mathrm{~N} \mathrm{HCl}$. 
C. -- Dissolve 52 grams of ammonium molybdate in $\left.\left(\mathrm{NH}_{4}\right)_{6} \mathrm{Mo}_{2} \mathrm{O}_{2} 4 \mathrm{H}_{2} \mathrm{O}\right)$ in $250 \mathrm{ml}$ of ultra pure deionized water and then dilute this to 1 liter.

D. -- Dissolve 10 grams of EDTA in $250 \mathrm{ml}$ of ultra pure deionized water and dilute to 1 liter.

E. -- Dissolve 170 grams of sodium sulfate in $500 \mathrm{ml}$ of ultra pure deionized water and dilute to 1 liter.

Analytical Procedures:

Add $10 \mathrm{ml}$ of blank, standard or sample to an acid washed, rinsed and dried $50 \mathrm{ml}$ a screw-top test tube; then add the following:

$--5 \mathrm{ml}$ of the $\mathrm{HCl}$ solution, and vortex to mix well.

$-5 \mathrm{ml}$ of the ammonium molybdate solution and vortex to mix well. The remaining reagents must be added five minutes of adding the ammonium molybdate solution.

-- $5 \mathrm{ml}$ of the EDTA solution, vortex to mix well.

-- $10 \mathrm{ml}$ of the sodium sulfate solution, vortex to mix well.

Incubate in the dark, at a constant temperature for at least 30 minutes. Read the sample in the Milton Roy Spectronic ${ }^{\circledR} 401$ spectrophotometer, set to a wavelength of $700 \mathrm{~nm}$ with a cell having a path length of $5 \mathrm{~cm}$. 


\section{Major Cations: $\mathrm{Mg}, \mathrm{Na}, \mathrm{Ca}$ and $\mathrm{K}$}

The concentrations of major cations were determined from filtered and pre-acidified samples using (flame) atomic absorption methods. The procedures followed were those recommended by the manufacturer of the instrument (Perkin-Elmer AAnalyst-300 spectrometer) and Beaty and Kerber (1993). The handling of the sample followed the recommendations of Jones, (1994).

Reagents:

A. -- The calcium, sodium, potassium and magnesium standards used in this study came from commercial stock solutions (Sigma corporation). Make three different solutions with concentrations ranging from $0.5-10 \mathrm{mg}$ Cation/L. Make an independent control blank. Standards can be made in the laboratory as follows:

K standard: stock standard: $1000 \mathrm{mg} / \mathrm{L}$

Dissolve 1.907 grams of $\mathrm{KCl}$ in $250 \mathrm{ml}$ of ultra pure deionized water and then dilute this to 1 liter. For interferences add $0.1 \%$ or more Cs or La to samples (Perkin-Elmer, 1993).

Mg standard: stock standard: $100,000 \mu \mathrm{g} / \mathrm{L}$

Dissolve 0.1658 gram of $\mathrm{MgO}$ in $50 \mathrm{ml}$ of ultra pure deionized water, add $10 \mathrm{ml}$ of concentrated $\mathrm{HNO}_{3}$, and then dilute this to 1 liter. (APHA, 1998). 
Na standard: stock standard: $1000 \mathrm{mg} / \mathrm{L}$

Dissolve 2.542 grams of $\mathrm{NaCl}$ in $50 \mathrm{ml}$ of ultra pure deionized water and then dilute this to 1 liter. For interferences add $0.1 \%$ or more $\mathrm{K}$ or $\mathrm{Cs}$ to samples (Perkin-Elmer, 1993).

Ca standard: stock standard: $500 \mathrm{mg} / \mathrm{L}$

Dissolve 1.249 grams of $\mathrm{CaCO}_{3}$ in $50 \mathrm{ml}$ of ultra pure deionized water.

Dissolve by adding the water drop-wise (slowly), add $10 \mathrm{ml}$ of $\mathrm{HCl}$, and then dilute this to 1 liter. For interferences add alkali salt $(0.1 \%$ or more of $K$ as KCl) to samples (Perkin-Elmer, 1993).

\section{Chlorophyll-a}

The phaeophytin-corrected chlorophyll-a analysis followed the procedure outlined in Daggett (1994), Axler and Owen (1994) and Honea (1997).

Collect water sample in a dark bottle and filter in the dark within two hours of collection. Use a glass microfiber filter (Whatman ${ }^{\circledR} \mathrm{GF} / \mathrm{F} 47 \mathrm{~mm}$ ) with a nominal pore size of $0.45 \mathrm{um}$. Wash filters with deionized water, and oven-dry at $55^{\circ} \mathrm{C}$. for at least 48 hours. To filter use a Nalgene ${ }^{\circledast}$ hand pump filtration set up or a similar filtration set-up. After filtering add three drops of saturated $\mathrm{MgCO}_{3}$ to the filter. Place the filter in a filter holder, wrap in foil 
and place it in ice and freeze until analysis. Before start of analysis create standards to calibrate the instrument (Wetzel and Likens, 1991).

Materials:

Chlorophyll-a standards.

95\% methanol (spectrophotometric grade).

$0.12 \mathrm{~N} \mathrm{HCl}$ (1 part $36.5-38 \% \mathrm{HCl}$ to 99 parts deionized water).

$20 \mathrm{ml}$ of saturated $\mathrm{MgCO}_{3}$ solution.

Two $15 \mathrm{ml}$ fluorometry cuvettes with caps per sample.

One $15 \mathrm{ml}$ fluorometry cuvettes with caps per standard.

Pipettes (10 to $200 \mathrm{ml})$.

Turner Designs Fluorometer Model 10-005R (No.5564) calibrated for chlorophyll. Turn on the fluorometer 30 minutes before use.

Procedures:

Label the fluorometric cuvettes. Cut up the filters with the samples using tweezers, and place them in the $15 \mathrm{ml}$ fluorometry cuvettes. Add $10 \mathrm{ml}$ of 95\% methanol. Cap the cuvettes and shake it. Put cuvette rack in refrigerator for 6-8 hrs $\left(4^{\circ} \mathrm{C}\right)$.

Remove rack from refrigerator and invert tubes a couple times. If there is too much debris or cloudiness in suspension, filter or centrifuge the sample.

Decant extract or pour the filtrate into clean cuvettes. 
Read samples on fluorometer at room temperature and record fluorometer setting (settings 1-4, 1 being the lowest).

Acidify with $200 \mathrm{ml} 0.12 \mathrm{~N} \mathrm{HCl}$ and invert it 4-5 times to mix. Immediately neutralize with 4 drops saturated $\mathrm{MgCO}_{3}$ solution. Invert 4-5 times to mix.

Read on fluorometer at same setting as pre-acidified sample. Use equations listed here (Wetzel and Likens, 1991) to calculate chlorophyll-a concentration corrected for Phaeophytin.

Using the chlorophyll-a standards, and for each setting, calculate the values of $\tau$ and $F$. Where $\tau=R_{b} / R_{a}\left(R_{b}\right.$ is the reading before acidification, and $\mathrm{R}_{\mathrm{a}}$ is the reading after acidification) and $\mathrm{F}=\mathrm{chl}-\mathrm{a}$ standard concentration/scale reading.

To calculate the chlorophyll-a concentration using (Wetzel and Likens, 1991):

Chlorophyll-a $(\mu \mathrm{g} / \mathrm{l})=$

$\left\{(F)[(\tau /(\tau-1))]\left(R_{b}-R_{a}\right)\right\} \cdot($ vol. of extract/vol. of sample filtered) Phaeopigment $(\mu \mathrm{g} / \mathrm{l})=$

$\left\{(F)[(\tau /(\tau-1))]\left(\tau\left(R_{a}-R_{b}\right)\right\}\right.$ (vol. of extract/vol. of sample filtered)

Finally, pour methanol waste into receptacle, and take to the chemistry waste lab when the receptacle is full. 


\section{APPENDIX B. PLANKTON COUNTING METHODS.}

\section{Phytoplankton counting methods}

Water samples for phytoplankton analysis were collected with the Van Dorn bottle. To reach a $1 \%$ final concentration of Lugol's fixative, $2.5 \mathrm{ml}$ of Lugol's solution was added to the $250 \mathrm{ml}$ HDPE bottles marked for the phytoplankton samples. Once in the laboratory, this sample was stored in the dark, in a refrigerated room.

A modified sedimentation procedure was implemented to count the phytoplankton. Dominant organisms were identified to species, and the rest to genus. A minimum of 400-500 cells was counted from each sample.

Phytoplankton samples were placed on $250 \mathrm{ml}$ beaker, $10 \mathrm{~cm}$ tall, and allowed to settle for at least 5 days $(1.2$ hours $/ \mathrm{ml})$. Supernatant was decanted $( \pm 200 \mathrm{ml})$ and the remaining $50 \mathrm{ml}$ were placed on a test tube. This test tube was placed on a centrifuge ( $3000 \mathrm{rpm}$ for 10 minutes) and the supernatant was decanted again until only $20 \mathrm{ml}$ remained. Samples from this concentrate were placed on a Nannoplankton ${ }^{\circledR}$ counting chamber (PhycoTech, Inc., Minnesota).

The Nannoplankton ${ }^{\circledast}$ counting chamber is a modified PalmerMaloney counting cell. Most dominant organisms were identified to species, 
and most others to genus. At least 500 cells were counted using a Nikon Eclipse 600 microscope (magnifications of $100 x$ and $400 x$ ). The cells $/ \mathrm{ml}$ counts were transformed to $\mu \mathrm{m} / \mathrm{ml}$.

\section{Zooplankton counting methods}

The zooplankton samples were collected using a folding plankton net having a diameter of $49.5 \mathrm{~cm}$, and a pore-mesh size of $130 \mu \mathrm{m}$. The filtration efficiency of the net was $100 \%$. The efficiency calculation was based on the following formula: volume of water filtered/ (Area of the mouth of the net times the distance or depth sampled (Wetzel and Likens, 1991).

Based on the temperature profile, and if a thermocline was present, the vertical ranges for sampling were decided as follows: The epilimnion sample covered the range from the surface of the reservoir to the beginning of the metalimnion. The composite hypolimnion-metalimnion sample covered the range from $1 \mathrm{~m}$ above the bottom of the reservoir to the boundary between the metalimnion and the epilimnion. These ranges varied in depth according to the water levels. During part of the fall 1998, the winter 1999 and part of the spring of 1999 , when there was no stratification, the range covered the entire water column. 
The zooplankton was concentrated in the built-in collector bottle that had a window covered with a fine mesh $(48 \mu \mathrm{m})$. From the collector the sample was transferred to the HDPE bottle marked for the zooplankton samples. These bottles had been acid washed in the lab, and rinsed with water from the reservoir. Depending on the amount of water in the sample, from 1 to $3 \mathrm{ml}$ of buffered formalin ( $40 \%$ formaldehyde) was added to preserve the organisms; the aim was to achieve a final concentration of $4 \%$. Once in the laboratory, this sample was stored in the dark, in a refrigerated room.

Zooplankton samples were mixed by shaking, and $50 \mathrm{ml}$ were placed on a test tube. This test tube was placed on a centrifuge ( $3000 \mathrm{rpm}$ for 10 minutes) and the supernatant was decanted again until only $20 \mathrm{ml}$ remained. Samples from this concentrate were placed on a Sedgwick-Rafter counting cell. Most dominant organisms were identified to species, and most others to genus. At least 400 individuals were counted using a Nikon Eclipse 600 microscope (magnifications of $100 x$ and $400 x$ ). The individuals per $\mathrm{ml}$ counts were transformed to $\mu \mathrm{m}$ per $\mathrm{ml}$. 